\title{
PROPOSTA ARQUITETÔNICA PARA O MUSEU DE HISTÓRIA GEOLÓGICA DA AMAZÔNIA
}

LUCIANA DA SILVA FLORENZANO

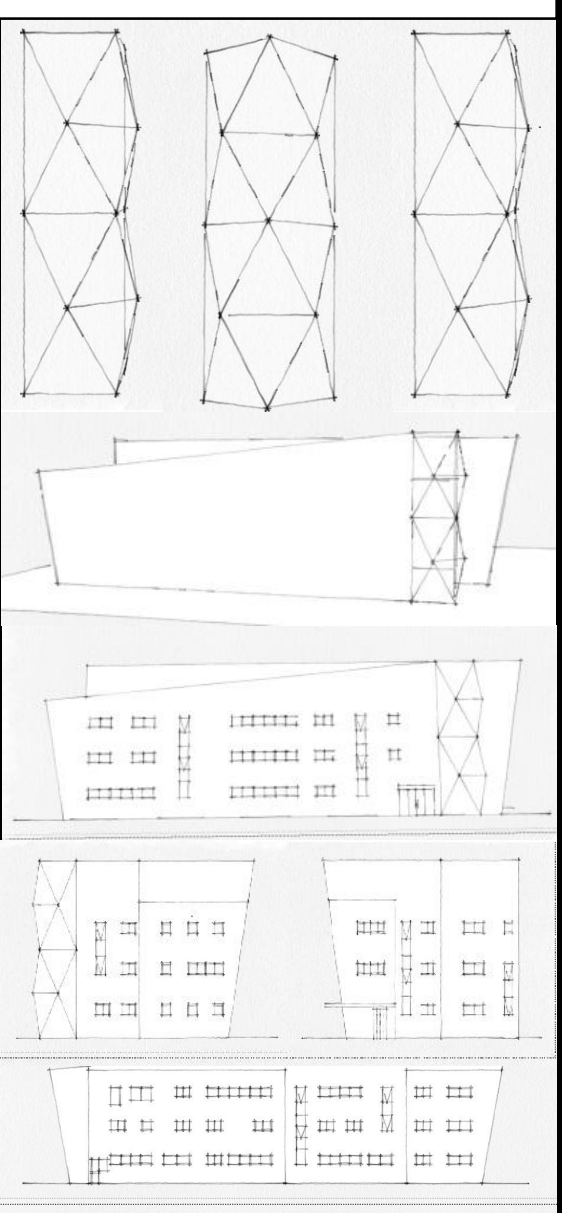




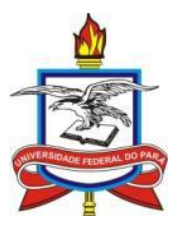

UNIVERSIDADE FEDERAL DO PARÁ INSTITUTO DE TECNOLOGIA

FACULDADE DE ARQUITETURA E URBANISMO

PROPOSTA ARQUITETÔNICA PARA

O MUSEU DE HISTÓRIA GEOLÓGICA DA AMAZÔNIA

PROF ${ }^{\mathrm{a}}$. ORIENTADORA: THAIS A. B. CAMINHA SANJAD

PROF ${ }^{\mathrm{a}}$. CO-ORIENTADORA: ROSANGELA MARQUES DE BRITTO 


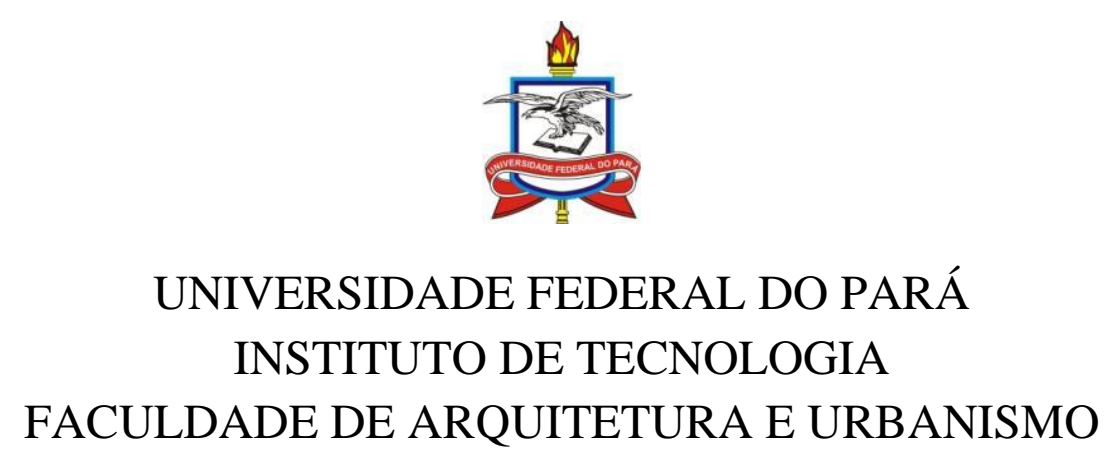

PROPOSTA ARQUITETÔNICA PARA

O MUSEU DE HISTÓRIA GEOLÓGICA DA AMAZÔNIA

Trabalho Final de Graduação apresentado à

Faculdade de Arquitetura e Urbanismo da Universidade Federal do Pará - UFPa como prérequisito para obtenção do Título de Bacharel em Arquitetura e Urbanismo.

Prof ${ }^{\mathrm{a}}$. Dr. ${ }^{\mathrm{a}}$ Orientadora: Thais A. B. Caminha Sanjad Prof ${ }^{a}$. Msc. Co-Orientadora: Rosangela Marques de Britto

BELÉM - PA

2011 


\section{量量 \\ UNIVERSIDADE FEDERAL DO PARÁ INSTITUTO DE TECNOLOGIA \\ FACULDADE DE ARQUITETURA E URBANISMO \\ LUCIANA DA SILVA FLORENZANO}

Esta monografia foi julgada e aprovada para obtenção do Título de Bacharel em Arquitetura e Urbanismo pela Universidade Federal do Pará.

Aprovada em:

BANCA EXAMINADORA

Prof $^{a}$. Dr ${ }^{\mathrm{a}}$. Thais A. B. Caminha Sanjad (Orientadora)

Universidade Federal do Pará

Prof ${ }^{a}$. Msc. Roseane da Conceição Costa Norat Universidade Federal do Pará

Msc. Flávia Olegário Palácios

Universidade Federal do Pará

BELÉM - PA 
"O desenvolvimento da moderna arquitetura não pode ser como um broto novo em um tronco velho; é um crescimento que vêm da raiz”. Walter Gropius 


\section{AGRADECIMENTOS}

Nesse árduo período do ano de 2011, o qual eu dediquei quase que exclusivamente a finalizar de forma positiva essa etapa da minha vida, algumas pessoas foram de extrema importância. Em primeiro lugar, a minha avó Cezarina, por me oferecer todas as oportunidades que podia e acima de tudo, por acreditar no meu sucesso.

A minha irmã e melhor amiga, Amanda, pela sua eterna paciência e companheirismo dedicados a mim durante todos os anos da nossa vida.

As minhas amigas da UFPa, pelo apoio mútuo, e em especial a Renata, pela parceria consolidada durante os últimos cinco anos.

À minha orientadora, Thaís Sanjad, por ter me guiado pelo caminho da boa arquitetura, não somente neste ano, mas ao longo de toda a minha formação acadêmica.

À minha co-orientadora Rosângela Britto, por ter disponibilizado seu tempo, seus livros, e toda ajuda possível para que esse trabalho fosse finalizado com rigor científico.

Ao professor Marcondes Lima da Costa, que me recebeu dentro do Museu de Geociências de portas abertas, e me deu diversas informações essenciais para este trabalho.

Aos meus colegas do escritório, em especial a Talita, a Silvana, a Luciana e o Carlos, pelas inúmeras vezes em que se mostraram solícitos em responder as minhas dúvidas.

À todos os integrantes do Laboratório de Conservação e Restauração da UFPa (LACORE), que acompanharam minhas angústias e alegrias durante esse ano.

À Eugélica, pelo apoio, força e inúmeras revisões realizadas durante a elaboração da proposta arquitetônica.

Ao Wagner, que mesmo não estando ao meu lado, dividiu comigo todas as preocupações, inquietações, conquistas e vitórias realizadas até aqui. Participando ativamente em todas as etapas do desenvolvimento deste trabalho e dando-me infinitas provas do seu amor.

Aos que eu não mencionei, mas que, de alguma forma, participaram na elaboração deste trabalho, minha eterna gratidão pela ajuda prestada. 


\section{RESUMO}

Os limites de um museu vão além das áreas de exposições. Tais instituições participam ativamente na sociedade por meio de atividades voltadas para diversos setores relacionados à comunicação e educação com o público, sobretudo, por meio de constantes pesquisas científicas. Simultaneamente, os museus contemporâneos atuam como incentivo ao turismo local. Estas análises levaram à conclusão da necessidade de criar na cidade de Belém, um museu voltado para o conhecimento mineralógico da região, em grande parte desconhecido pela população. Após todos os estudos acerca do tema e dos levantamentos de informações, o presente trabalho propõe um projeto arquitetônico para sediar o atual Museu de Geociências, da Universidade Federal do Pará. A proposta buscou englobar um partido arquitetônico, caracterizado pela tipologia de arquitetura mineral, em conjunto a um fluxograma interno voltado para salvaguarda do acervo e para setores de comunicação com o público, bem como pesquisas realizadas pela instituição. Dessa forma, este trabalho reúne conteúdo informacional sobre composições arquitetônicas e a prática das mesmas durante o século XX, em paralelo a uma pesquisa realizada sobre a arquitetura de museus na cidade de Belém e sobre o acervo do Museu de Geociências da UFPa.

Palavras chave: Arquitetura, Museu, Geociências. 


\begin{abstract}
The boundaries of a museum go beyond their exhibition areas. Such Institutions have an active participation in our society through activities focused at various sectors regarding education and communication to the people, and also, especially through constant scientific researches. Also, at the same time, a modern museum acts as an incentive to the local tourism. The analysis presented led to the conclusion that of the need of building in the city of Belém, a museum dedicated to the mineralogical knowledge of the region, mostly unknown by the population. After all the research regarding the theme, this following thesis proposes an architectural project to host the current Museum of Geosciences of the Federal University of the State of Pará. The proposal sought to include an architectonic party characterized by the typology of the mineral architecture together with an internal flowchart focused on safeguarding the collection and public communication sections, as well as researches made by the institution. Thus, this thesis gathers informational content about modes of architectural compositions, and the implementation of the composition aforementioned during the 20th century, in parallel with a study on the architecture of museum in the city of Belém and the collection of the Museum of Geosciences of the Federal University of the state of Pará.
\end{abstract}

Keywords: Architecture, Museum, Geosciences. 


\section{SUMÁRIO}

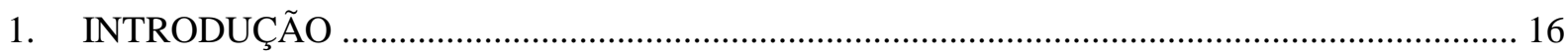

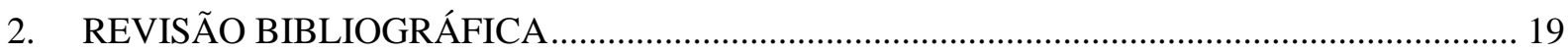

2.1. PRINCÍPIOS FUNDAMENTAIS DA ARQUITETURA................................. 19

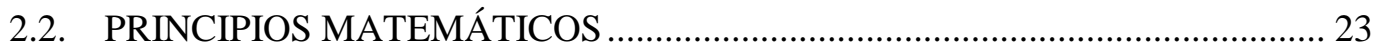

2.3. A CONSTRUÇÃO DA FORMA NA ARQUITETURA …............................... 27

2.3.1. A arquitetura a partir do movimento moderno ................................................... 27

2.3.2. O desenvolvimento da engenharia através do Concreto armado............................ 30

2.3.3. Le Corsbusier: Sistema Dom-ino e os cincos pontos para uma nova arquitetura . 31

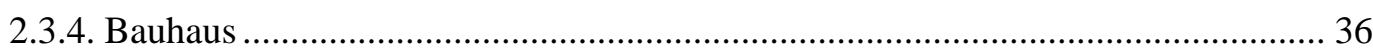

2.3.5. A construção da forma através do movimento Neoplasticista .............................. 36

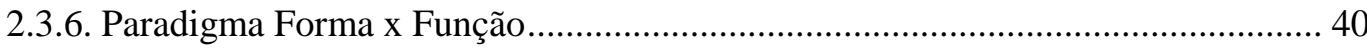

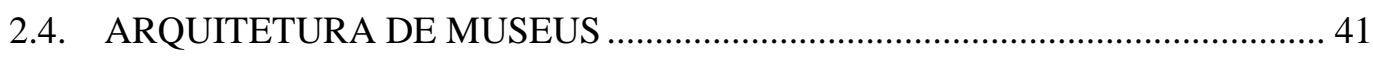

2.4.1. Origem e desenvolvimento dos museus ........................................................... 41

2.4.2. Museu na modernidade …………………........................................................ 44

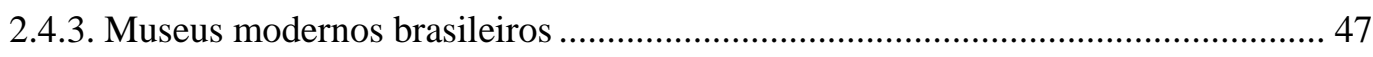

2.4.4. Museu Contemporâneo........................................................................................... 49

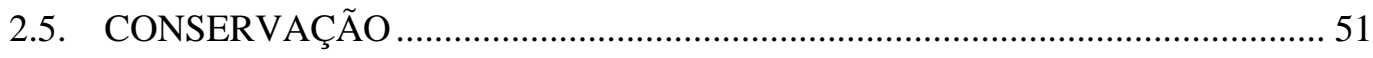

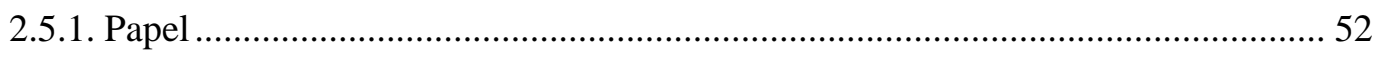

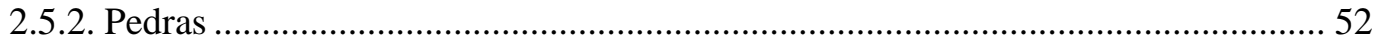

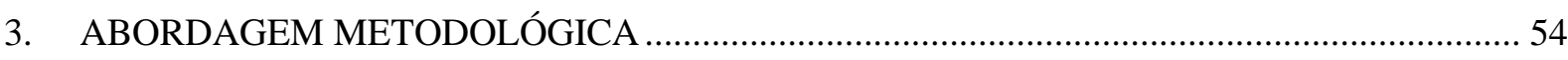

4. ARQUITETURA DE MUSEUS NA CIDADE DE BELÉM …............................................... 56

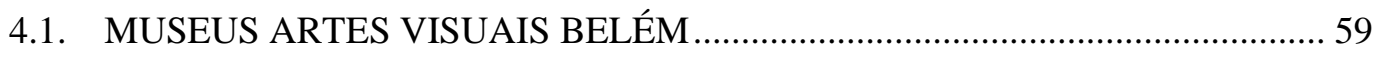

4.1.1. Museu de Arte de Belém .................................................................................... 59

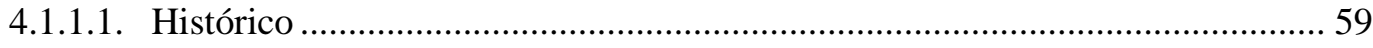

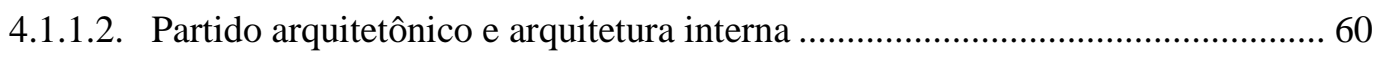

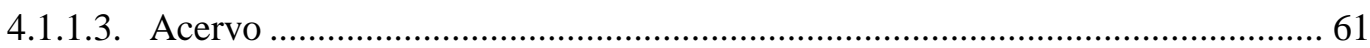




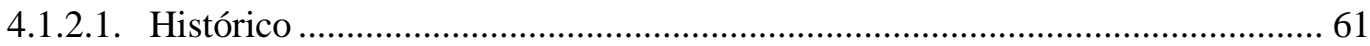

4.1.2.2. Partido arquitetônico e arquitetura interna ...................................................... 62

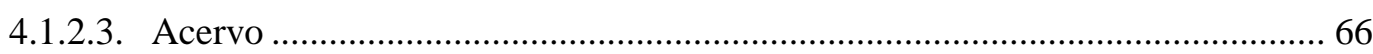

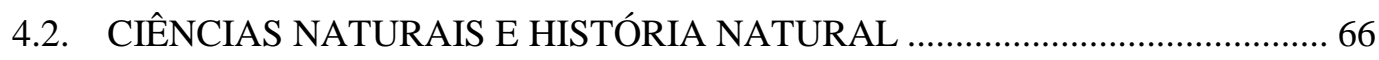

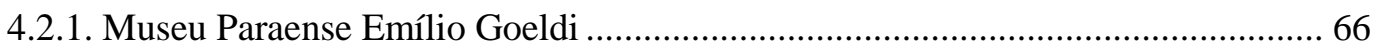

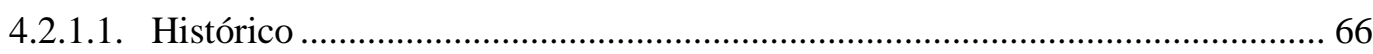

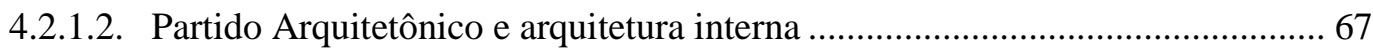

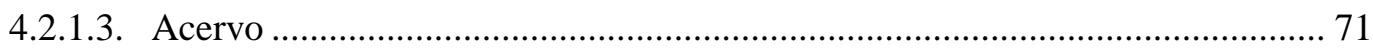

4.2.2. Museu de Gemas (Espaço São José Liberto) ........................................................ 71

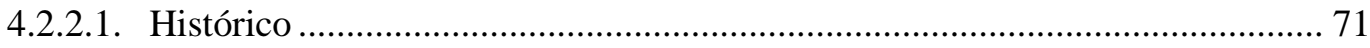

4.2.2.2. Partido Arquitetônico e arquitetura interna .................................................. 72

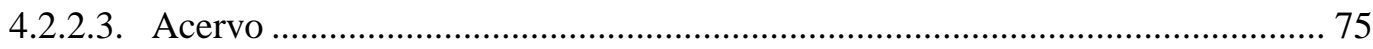

5. MUSEU DE GEOCIÊNCIAS DA UNIVERSIDADE FEDERAL DO PARÁ .............................. 77

5.1. Histórico do Instituto de Geociências................................................................... 77

5.2. Histórico do Museu de Geociências ...................................................................... 79

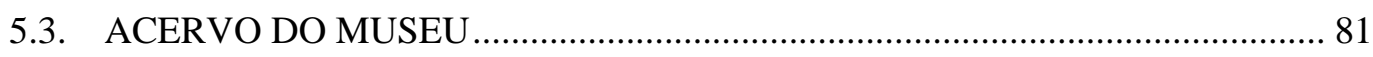

5.3.1. Exposição Permanente …….............................................................................. 82

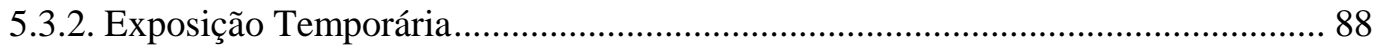

6. PROPOSTA ARQUITETÔNICA PARA O MUSEU DE HISTÓRIA GEOLÓGICA DA

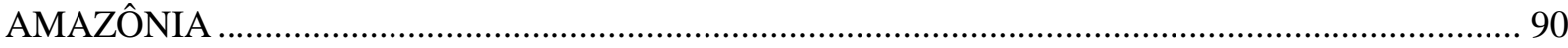

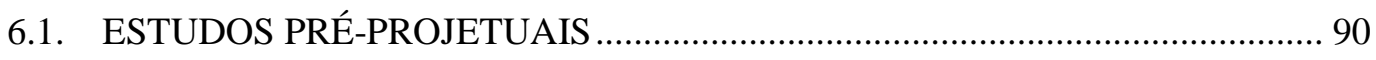

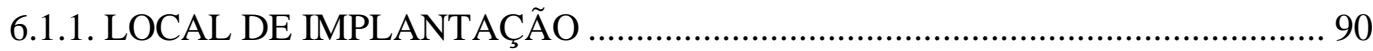

6.1.2. PROGRAMA DE NECESSIDADES ............................................................... 92

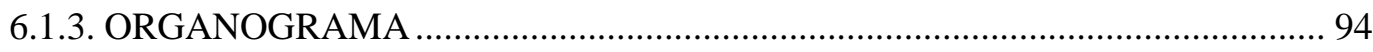

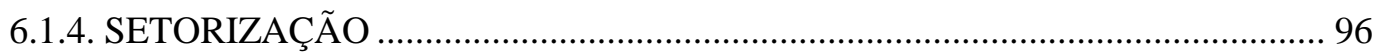

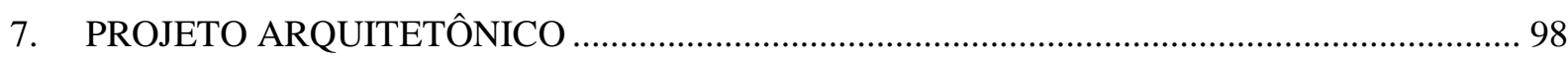




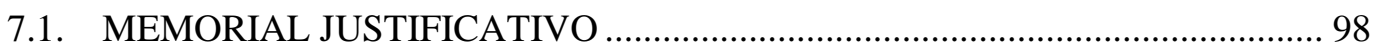

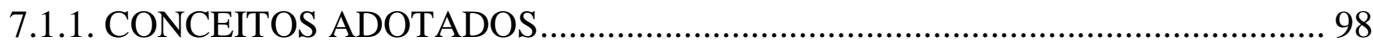

7.1.2. ELABORAÇÃO DO PARTIDO ARQUITETÔNICO ......................................... 99

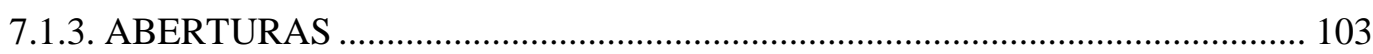

7.1.4. PARTIDO ARQUITETÔNICO FINAL …......................................................... 105

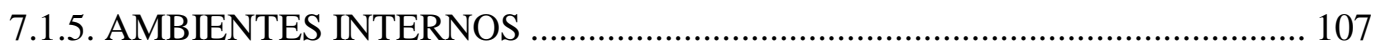

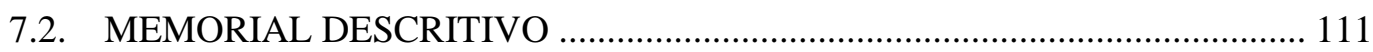

7.2.1. CARACTERÍSTICAS GERAIS DO EDÍFICIO ............................................. 111

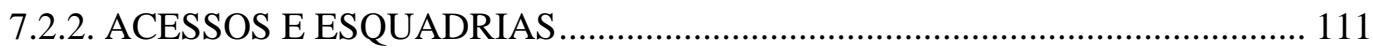

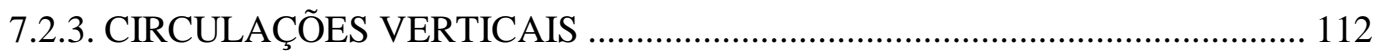

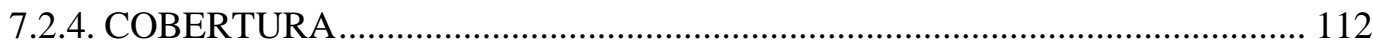

7.2.5. ESPECIFICAÇÕES POR AMBIENTE: ..................................................... 112

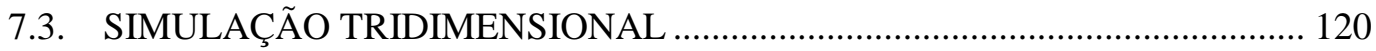

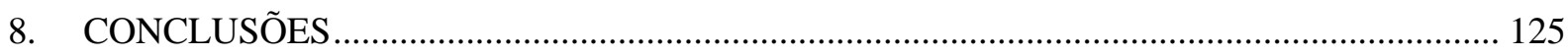

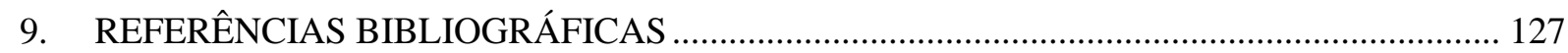

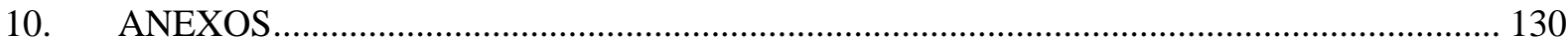




\section{LISTA DE ILUSTRAÇÕES}

FIGURA 1: TRONCO VEGETAL FOSSILIZADO, DO PERÍODO PERMIANO. ACERVO DO MUSEU.

FIGURA 2: TURBINELLA TURBERCULATA. ACERVO DO MUSEU.

FIGURA 3: MINERAL ENCONTRADO NOS ESTADOS UNIDOS. ACERVO DO MUSEU.

FIGURA 4: CONDRITO H5 IPITINGA. METEORITO NO PARÁ. ACERVO DO MUSEU.

FIGURA 5: DIAGRAMA DA GÊNESE DO ESPAÇO ARQUITETÔNICO. 20

FIGURA 6: PLANTA BAIXA VILLA ROTONDA. 21

FIGURA 7: PALÁCIO DO PLANALTO. 22

FIGURA 8: PARTENON 23

FIGURA 9: O HOMEM VITRUVIANO, DE LEONARDO DA VINCI......................................... 24

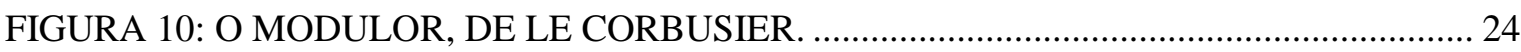

FIGURA 11: CONSTRUÇÃO CLÁSSICA DA SECÇÃO ÁUREA. .............................................. 25

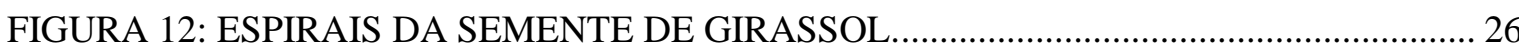

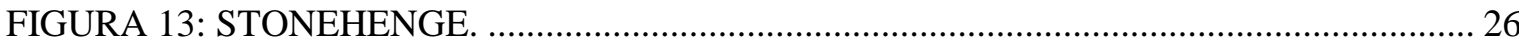

FIGURA 14: ESTUDO DO ALINHAMENTO DE STONEHENGE. ……..................................... 27

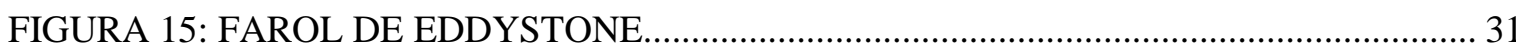

FIGURA 16: PRIMEIRA EMBARCAÇÃO CONSTRUIIDA EM CONCRETO ARMADO

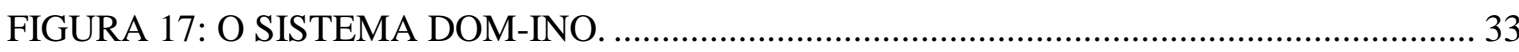

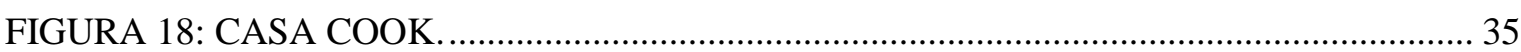

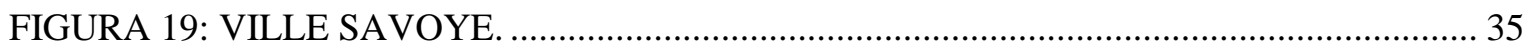

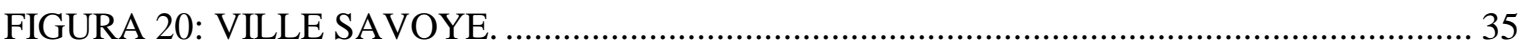

FIGURA 21: VILLA EM HUIS TER HEIDE, DE ROB VAN T'HOFF....................................... 38

FIGURA 22: PLANTA BAIXA DO SEGUNDO PAVIMENTO DA CASA SCHRODER, COM AS DIVISÓRIAS

FIGURA 23: PLANTA BAIXA DO SEGUNDO PAVIMENTO DA CASA SCHRODER, SEM AS DIVISÓRIAS. 
FIGURA 25: INTERIOR CASA SCHRODER. 39

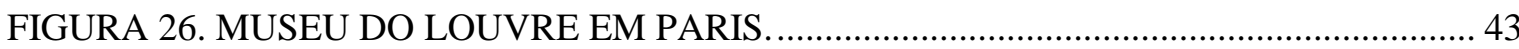

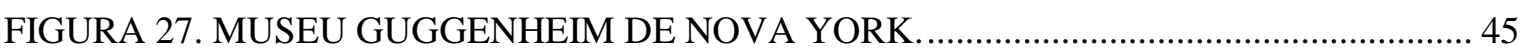

FIGURA 28. MODELO DE LE CORBUSIER PARA MUSEU DE CRESCIMENTO ILIMITADO. 46

FIGURA 29. MUSEU DE ARTE OCIDENTAL, PARQUE UENO, TÓQUIO. ............................. 46

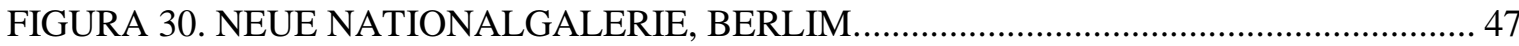

FIGURA 31. MUSEU DE ARTE MODERNA DO RIO DE JANEIRO ......................................... 48

FIGURA 32. MUSEU DE ARTE MODERNA DO RIO DE JANEIRO....................................... 48

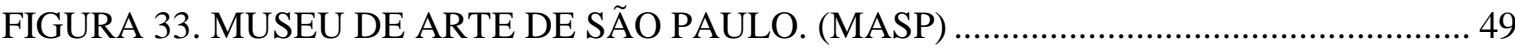

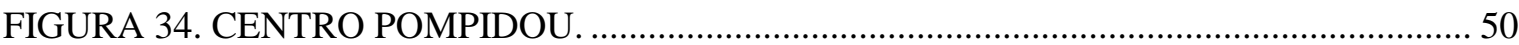

FIGURA 35. FUNDAÇÃO IBERÊ CAMARGO EM PORTO ALEGRE. ....................................... 50

FIGURA 36. MUSEU DE ARTE CONTEMPORÂNEA EM NITERÓI. (MAC) ........................... 51

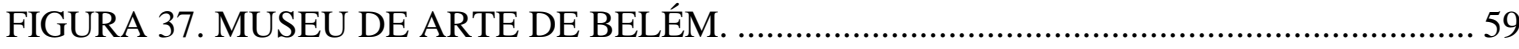

FIGURA 38. ESCADARIA EM MÁRMORE DO MUSEU DE ARTE DE BELÉM. .................... 60

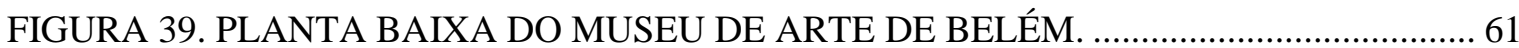

FIGURA 40. FACHADA DO MUSEU DA UNIVERSIDADE FEDERAL DO PARÁ. ................ 62

FIGURA 41. SALÃO DE EXPOSIÇÃO DO MUSEU DA UNIVERSIDADE FEDERAL DO PARÁ. 63

FIGURA 42. ESCADA DO MUSEU DA UNIVERSIDADE FEDERAL DO PARÁ..................... 63

FIGURA 43. ESCRITÓRIO DO GOVERNADOR AUGUSTO MONTENEGRO......................... 64

FIGURA 44. BIBLIOTECA DO MUSEU DA UNIVERSIDADE FEDERAL DO PARÁ 65

FIGURA 45. ANEXO DO MUSEU DA UNIVERSIDADE FEDERAL DO PARÁ....................... 65

FIGURA 46. JARDIM DO MUSEU DA UNIVERSIDADE FEDERAL DO PARÁ....................... 66

FIGURA 47. PAVILHÃO DOMINGO SOARES FERREIRA PENA (PRÉDIO DA ROCINHA) DO MUSEU PARAENSE EMÍLIO GOELDI.

FIGURA 48. EXPOSIÇÃO NO PRÉDIO DA ROCINHA DO MUSEU PARAENSE EMÍLIO GOELDI

FIGURA 49: ARTEFATOS ARQUEOLÓGICOS EM EXPOSIÇÃO NO PRÉDIO DA ROCINHA DO MUSEU PARAENSE EMÍLIO GOELDI. 
FIGURA 50: ARTEFATOS ARQUEOLÓGICOS EM EXPOSIÇÃO NO PRÉDIO DA ROCINHA DO MUSEU PARAENSE EMÍLIO GOELDI.

FIGURA 51. FACHADA DO ÁQUÁRIO JACQUES HUBER DO MUSEU PARAENSE EMÍLIO GOELDI. 69

FIGURA 52. CASTELINHO DO MUSEU PARAENSE EMÍLIO GOELDI. 70

FIGURA 53. ONÇA PINTADA DO MUSEU PARAENSE EMÍLIO GOELDI. ............................ 71

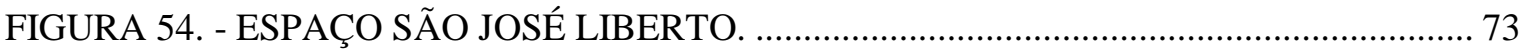

FIGURA 55. - OFICINA DE JÓIAS. ESPAÇO SÃO JOSÉ LIBERTO. ......................................... 73

FIGURA 56. - ARTESANATO LOCAL EXPOSTO NO ESPAÇO SÃO JOSÉ LIBERTO. 74

FIGURA 57. - COLISEU DAS ARTES, ESPAÇO SÃO JOSÉ LIBERTO.................................... 74

FIGURA 58. JARDIM DA LIBERDADE. ESPAÇO SÃO JOSÉ LIBERTO................................... 75

FIGURA 59. EXPOSIÇÃO PERMANENTE. ESPAÇO SÃO JOSÉ LIBERTO............................. 76

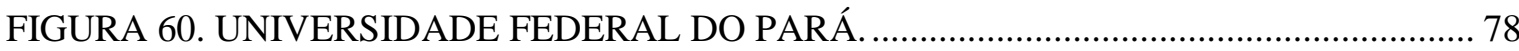

FIGURA 61. INSTITUTO DE GEOCIÊNCIAS E BIBLIOTECA SETORIAL.............................. 79

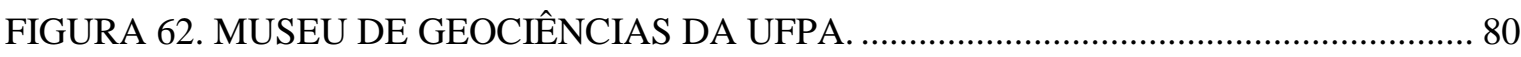

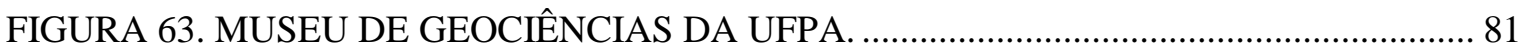

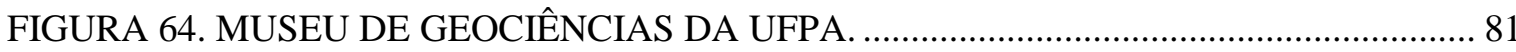

FIGURA 65. MAPA GEOLÓGICO DO BRASIL. ACERVO DO MUSEU DE GEOCIÊNCIAS DA UFPA.

FIGURA 66. MAPA GEOLÓGICO DO ESTADO DO PARÁ. ACERVO DO MUSEU DE GEOCIÊNCIAS DA UFPA...................................................................... 83

FIGURA 67: TURMALINA PRETA DO MUSEU DE GEOCIÊNCIAS DA UFPA...................... 84

FIGURA 68: AMETISTA DO MUSEU DE GEOCIÊNCIAS DA UFPA.......................................... 84

FIGURA 69: CALCITA PLACOSA E TRIDIMITA SOBRE QUARTZO DO MUSEU DE GEOCIÊNCIAS DA UFPA.

FIGURA 70: SIDERITA, DOLOMITA E PIRROTITA DO MUSEU DE GEOCIÊNCIAS DA UFPA. .84

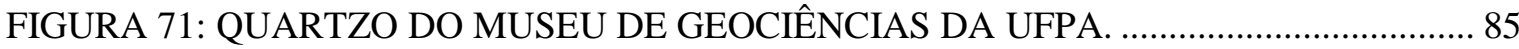

FIGURA 72: ZINNWALDITA DO MUSEU DE GEOCIÊNCIAS DA UFPA. ............................. 85

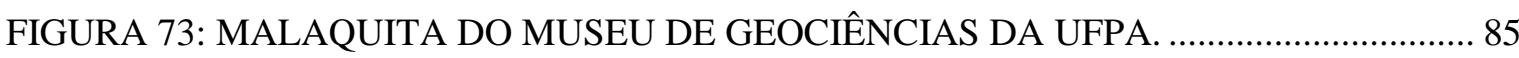

FIGURA 74: TOPÁZIO DO MUSEU DE GEOCIÊNCIAS DA UFPA. ……................................... 85 
FIGURA 75: FOSFATO ALUMINOSO PISOLÍTICO TIPO CRANDALITA, DO MUSEU DE GEOCIÊNCIAS DA UFPA 86

FIGURA 76: VEIO PEGMATÓIDE COM MUSCOVITA, EPIDOTO, TURMALINA E QUARTZO, DO MUSEU DE GEOCIÊNCIAS DA UFPA 86

FIGURA 77: MACHADINHA ÍNDIGENA EM ROCHA BÁSICA, ACERVO DO MUSEU DE GEOCIÊNCIAS DA UFPA.

FIGURA 78: MACHADINHA ÍNDIGENA EM ROCHA SUBVULCÂNICA, ACERVO DO MUSEU DE GEOCIÊNCIAS DA UFPA 86

FIGURA 79: FOSSÉIS DA FORMAÇÃO PIRABAS, ACERVO DO MUSEU DE GEOCIÊNCIAS DA UFPA.

FIGURA 80: FOSSÉIS DA FORMAÇÃO PIRABAS, ACERVO DO MUSEU DE GEOCIÊNCIAS DA UFPA.

FIGURA 81: FOSSÉIS DA BACIA DO PARANÁ, ACERVO DO MUSEU DE GEOCIÊNCIAS DA UFPA.

FIGURA 82: FOSSÉIS DA BACIA DO PARANÁ, ACERVO DO MUSEU DE GEOCIÊNCIAS DA UFPA.

FIGURA 83: PEGADA DO CARNOTAURUS SP, ACERVO DO MUSEU DE GEOCIÊNCIAS DA UFPA.

FIGURA 84: DENTES DE F.C PURUSSAURUS (CRODILÍDEOS), ACERVO DO MUSEU DE GEOCIÊNCIAS DA UFPA 88

FIGURA 85: PIRITA COM ESFARELITA E CASSITERITA, ACERVO DO MUSEU DE GEOCIÊNCIAS DA UFPA. 88

FIGURA 86: MINERAIS DE GEMAS, ACERVO DO MUSEU DE GEOCIÊNCIAS DA UFPA.

FIGURA 87: MINERAIS DE GEMAS, ACERVO DO MUSEU DE GEOCIÊNCIAS DA UFPA

FIGURA 88: TERRENO PARA IMPLANTAÇÃO DO MUSEU DE HISTÓRIA GEOLÓGICA DA AMAZÔNIA.

FIGURA 89: TERRENO PARA IMPLANTAÇÃO DO MUSEU DE HISTÓRIA GEOLÓGICA DA AMAZÔNIA.

FIGURA 90: ORGANOGRAMA. 95

FIGURA 91: SETORIZAÇÃO DO PAVIMENTO TÉRREO. 96

FIGURA 92: SETORIZAÇÃO DO $2^{\circ}$ PAVIMENTO. 97

FIGURA 93: SETORIZAÇÃO DO $3^{\circ}$ PAVIMENTO. 97

FIGURA 94. LOCALIZAÇÃO DO TERRENO NA UFPA. 98

FIGURA 95: ETAPA 01DO DESENVOLVIMENTO PROJETUAL 99 
FIGURA 96: ETAPA 02 DO DESENVOLVIMENTO PROJETUAL ............................................ 99

FIGURA 97: ETAPA 03 DO DESENVOLVIMENTO PROJETUAL ........................................... 100

FIGURA 98: ETAPA 04 DO DESENVOLVIMENTO PROJETUAL .......................................... 100

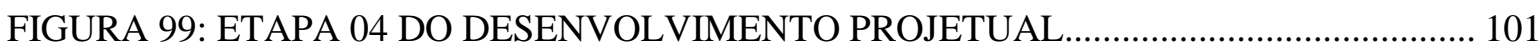

FIGURA 100: ETAPA 04 DO DESENVOLVIMENTO PROJETUAL. ...................................... 101

FIGURA 101: CROQUI CRISTALIZAÇÃO DIAMANTE ....................................................... 102

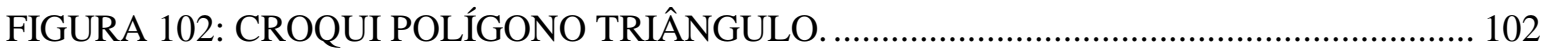

FIGURA 103: CROQUI ESTRUTURA CRISTALINA VERTICAL. VISTA

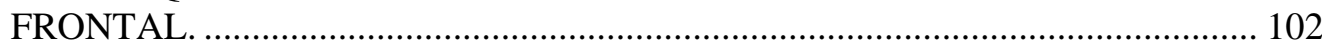

FIGURA 104: CROQUI ESTRUTURA CRISTALINA VERTICAL. VISTA

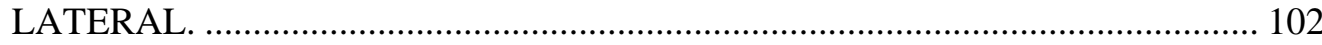

FIGURA 105: ETAPA 06 DO DESENVOLVIMENTO PROJETUAL. .......................................... 103

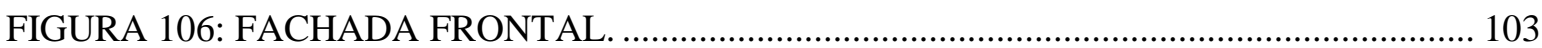

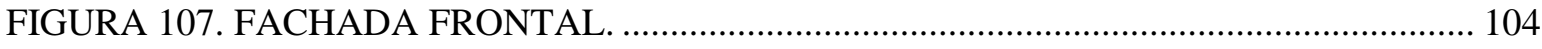

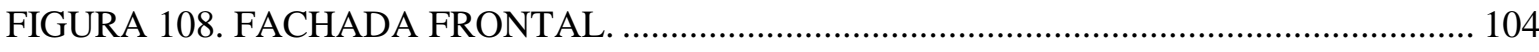

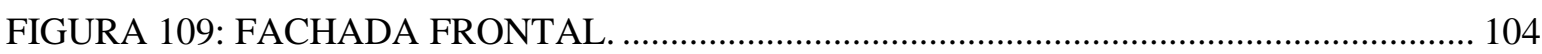

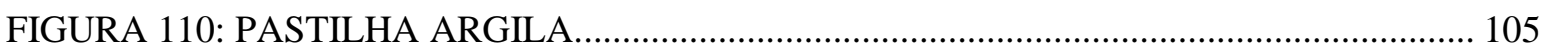

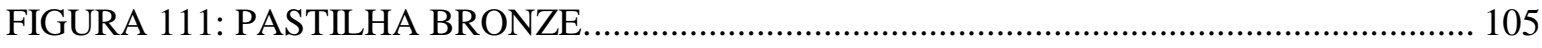

FIGURA 112: PARTIDO ARQUITETÔNICO FINAL. ................................................................ 106

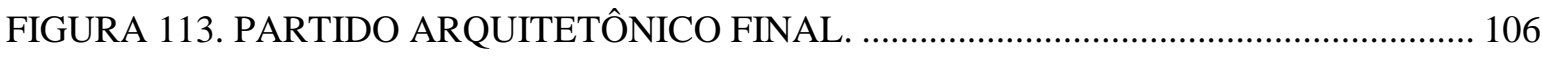

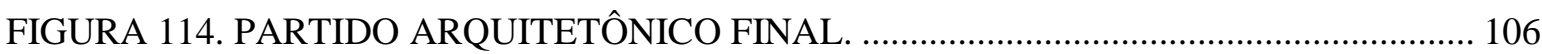

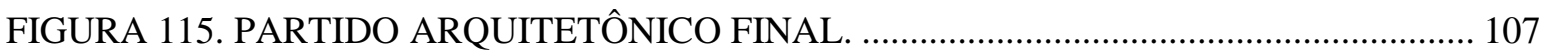

FIGURA 116. LOCALIZAÇÃO DOS ACESSOS DO MUSEU. ................................................... 107

FIGURA 117: DODECAGÓNO EM PLANTA NO PAVIMENTO TÉRREO. ............................... 109

FIGURA 118: SECÇÃO ESQUEMÁTICA DA ABERTURA ZENITAL E CONSEQUENTE INTEGRAÇÃO ENTRE AS EXPOSIÇÕES

FIGURA 119: PAINÉIS GEOMÉTRICOS CRIADOS A PARTIR DA ILUSÃO DE ÓTICA.

FIGURA 120: FACHADA PRINCIPAL PROPOSTA ARQUITETÔNICA PARA O MUSEU DE HISTÓRIA GEOLÓGICA DA AMAZÔNIA 
FIGURA 121: PROPOSTA ARQUITETÔNICA PARA O MUSEU DE HISTÓRIA GEOLÓGICA DA AMAZÔNIA

FIGURA 122: PROPOSTA ARQUITETÔNICA PARA O MUSEU DE HISTÓRIA GEOLÓGICA DA AMAZÔNIA

FIGURA 123: PROPOSTA ARQUITETÔNICA PARA O MUSEU DE HISTÓRIA GEOLÓGICA DA AMAZÔNIA.

FIGURA 124: PROPOSTA ARQUITETÔNICA PARA O MUSEU DE HISTÓRIA GEOLÓGICA DA AMAZÔNIA 


\section{INTRODUÇÃO}

Os museus como conhecemos atualmente tem origem ao final do século XVIII (RIBEIRO, 1993). Entretanto, sua essência possui por volta de 2,5 milhões de anos a.C, desde o período pré-histórico do paleolítico, quando surgiu no homem o costume de colecionar objetos, até a condição contemporânea, da inserção dessa instituição no contexto da globalização e pluralidade de funções. Atualmente, o papel dele está ligado não somente à difusão do seu acervo, mas à transmissão de valores, sendo ele um organismo vivo na vida dos homens.

Dessa forma é possível presenciar cada vez mais o museu no cotidiano da sociedade, não somente pelas exposições visuais, mas também em todos os sentidos, com mostras de cinema, oficinas e palestras. Portanto, seu espaço físico precisa abrigar distintas funções devido à procura cada vez maior do público, sendo necessários ambientes para alimentação, comercialização e áreas de convivência. Em paralelo a essas atividades, o museu contemporâneo não deve somente ser visto, ele deve ser sentido e absorvido. Logo, o setor mais importante atualmente para qualquer instituição desse porte é o setor voltado para o desenvolvimento de pesquisas.

Na cidade de Belém, as instituições locais seguem essa atual tendência pós-moderna dos museus, como o Espaço São José Liberto, antigo presídio da cidade, atualmente Museu de Gemas de Belém. O São José Liberto é uma instituição onde é possível adquirir conhecimento sobre a história do lugar, com uma cela dedicada à memória da cruel realidade do presídio, assim como observar as etapas pela qual passa o seu acervo, os minerais, desde o produto in natura, o processo de lapidação e produção de jóias e finalmente a comercialização do produto final. Ao público também são ofertadas oficinas, eventos culturais, e comercialização do artesanato local.

Com relação aos museus minerais, existe ainda em paralelo ao espaço São José Liberto outro museu em Belém, cujo conhecimento pesquisado e difundido refere-se à mineralogia, porém de forma mais abrangente, englobando todas as Geociências.

As Geociências são as ciências que estudam o planeta Terra e estão diretamente ligadas ao estudo da geologia, cuja pesquisa e estudo referem-se à origem e desenvolvimento do corpo celeste em que habitamos, assim como os processos naturais de formações rochosas 
e minerais. Do mesmo modo, com o estudo da geologia é possível compreender a evolução da vida através dos registros fósseis deixados por animais já extintos.

Uma parcela desses estudos geológicos está voltada para a Amazônia e sua extensa diversidade, pois a floresta possui um dos maiores sítios minerais do mundo. A área, desde a época do descobrimento do Brasil, é fonte de interesse das ciências naturais, devido à sua biodiversidade, tanto em fauna e flora, quanto em minérios.

Para difundir todo esse conhecimento, surgiu e se desenvolveu um museu em Belém voltado para esse fim, o Museu de Geociências, do Instituto de Geociências, da Universidade Federal do Pará.

O acervo do museu foi reunido ao longo de quatro décadas, e tem amostras de minerais do mundo inteiro. O mesmo é visitado por estudantes de ensino fundamental, médio, graduandos e pós-graduandos da cidade de Belém e outras, que almejam compreender a história do planeta Terra. É um dos poucos da região Norte voltado para a divulgação das geociências, tanto em relação às pesquisas realizadas pelo Grupo de Mineralogia e Geoquímica Aplicada (GMGA), coordenado pelo professor Marcondes Lima da Costa, quanto em relação ao conhecimento geológico da Amazônia.

O museu é constituído em grande parte de amostras de minerais, rochas, cristais, gemas e fósseis da região Amazônica (Figura 01, 02, 03 e 04), entre outros minérios encontrados fora do país e mapas pertencentes ao Instituto de Geociências da Universidade Federal do Pará. (COSTA, 1999).

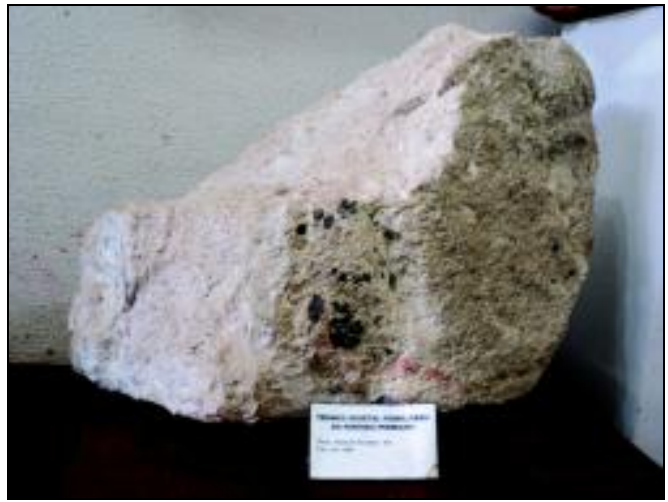

Figura 1: Tronco vegetal fossilizado, do período permiano. Acervo do Museu. Autor da foto: Luciana Florenzano, 2011

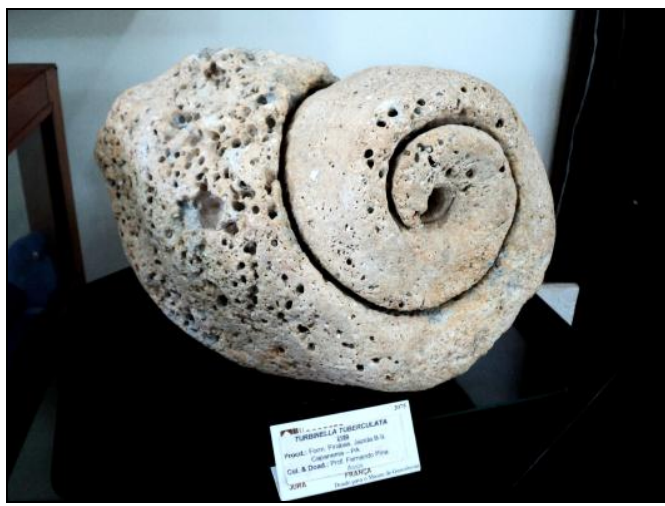

Figura 2: Turbinella Turberculata. Acervo do Museu.

Autor da foto: Luciana Florenzano, 2011. 


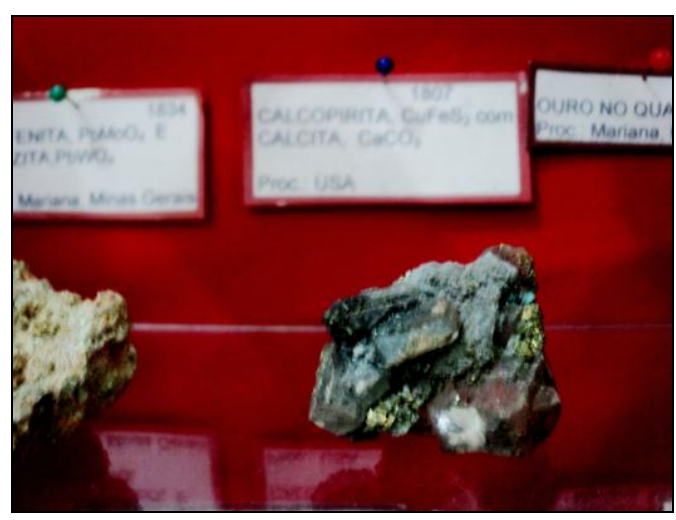

Figura 3: Mineral encontrado nos Estados Unidos. Acervo do Museu.

Autor da foto: Luciana Florenzano, 2011.

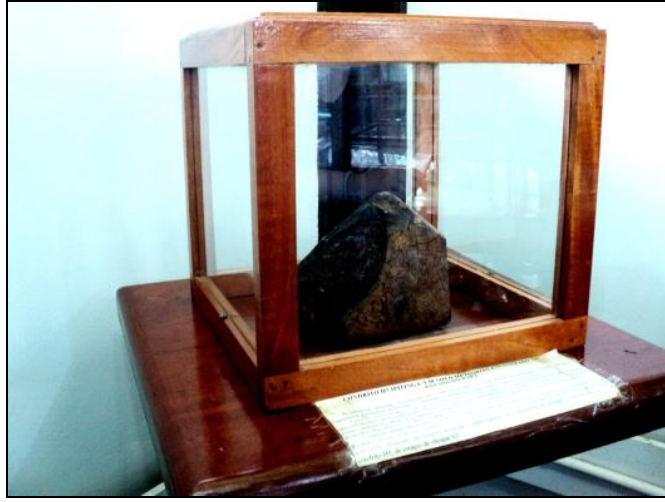

Figura 4: Condrito H5 Ipitinga. Meteorito no Pará. Acervo do Museu.

Autor da foto: Luciana Florenzano, 2011.

Devido à carência de um espaço maior, todo o acervo do Museu de Geociências está localizado em um corredor e uma sala dentro de um dos edifícios que compõem o parque geocientífico da UFPa. Dividindo dessa forma, o espaço com outros setores do Instituto de Geociências. Apesar do reduzido espaço físico em que as peças se encontram, elas estão agrupadas de acordo com sua natureza mineralógica e divididas em duas exposições, permanente e temporária.

O acervo do museu referente à exposição permanente é constituído por mapas geológicos, exemplares de minerais, rochas e fósseis. $\mathrm{Na}$ exposição temporária atual é possível ver minerais de gemas, artesanato e bio-jóias.

Infelizmente, nem todas as peças que compõem o acervo do museu estão em exposição, devido à falta de um espaço maior. E agregado a esse impasse, o museu não pode mais receber amostras para expandi-lo, uma vez que não há onde situá-las. A proposta arquitetônica para o Museu de História Geológica da Amazônia consiste na construção de um novo edifício, dessa forma, transferindo o acervo do museu, e criando um novo espaço físico para a instituição, a qual terá condições adequadas para expandir a coleção e organizá-la de forma estratégica para o melhor fluxo das pessoas e melhor contemplação da mesma, em paralelo a setores voltados à pesquisa e à formação acadêmica.

O objetivo desse trabalho é, portanto, a elaboração do projeto arquitetônico para o Museu de História Geológica da Amazônia, dentro do campus da Universidade Federal do Pará, com base em princípios matemáticos de forma, ritmo, proporção e equilíbrio, culminando em uma tipologia de arquitetura mineral voltada para a função museológica. 


\section{REVISÃO BIBLIOGRÁFICA}

A concepção arquitetônica é obviamente, diferente em cada período histórico. Em partes, porque a construção da forma está diretamente relacionada ao pensamento estético de cada grupo social. Por outro lado cada sociedade possui seus meios construtivos, os quais influenciam a representação da forma arquitetônica. Logo, a representação da arquitetura através de diferentes tipologias, acompanha os séculos de acordo com a cultura vigente da humanidade.

O presente trabalho pretende compreender o que é a forma, enquanto aparência básica, composta por conceitos matemáticos e conceitos fundamentais de composição, e enquanto representação da sociedade, principalmente a partir da ruptura com o classicismo, realizada através do movimento moderno do início do século XX. Para Mahfuz (2009), deve-se compreender a forma a partir de duas análises distintas.

A primeira compreende a forma enquanto figura e aparência das coisas, a partir de construções geométricas, princípios fundamentais e razões universais de proporcionalidade utilizadas na concepção arquitetônica.

A segunda diz respeito ao conceito de estrutura, vinculada ao movimento moderno e a construção da forma na arquitetura a partir das inovações tecnológicas e a análise da produção teórica e arquitetônica de algumas personalidades do século XX. A ênfase aqui será dada, principalmente, em relação à arquitetura de museus e a transformação que essa instituição teve ao longo da do século XX. A partir dessa compreensão sobre a concepção arquitetônica está a base para construção formal contemporânea, objetivo final desse estudo.

\subsection{PRINCÍPIOS FUNDAMENTAIS DA ARQUITETURA}

A forma é a combinação de conceitos matemáticos de linha, ponto e curva em um plano. Para Ching (2005) esses são os elementos primários geradores da forma. Um ponto indica uma posição no espaço. Uma reta transforma-se em um plano e esse plano dá origem ao volume. Por consequência tem-se uma forma. Para Arnheim (1997, p. 89) "forma é a configuração visível do conteúdo". Na arquitetura, ela é a representação dos desejos e necessidades do homem, estando sempre associada a um significado.

A forma se materializa no espaço. A espacialidade é uma característica inerente do ser 
humano, pois homem e espaço estão em uma constante co- relação, uma vez que no espaço se realizam as ações humanas.. Logo, o espaço cumpre simultaneamente funções simbólicas, funcionais e racionais (Figura 05), uma vez que abriga toda a existência humana. (MALARD, 2006.)

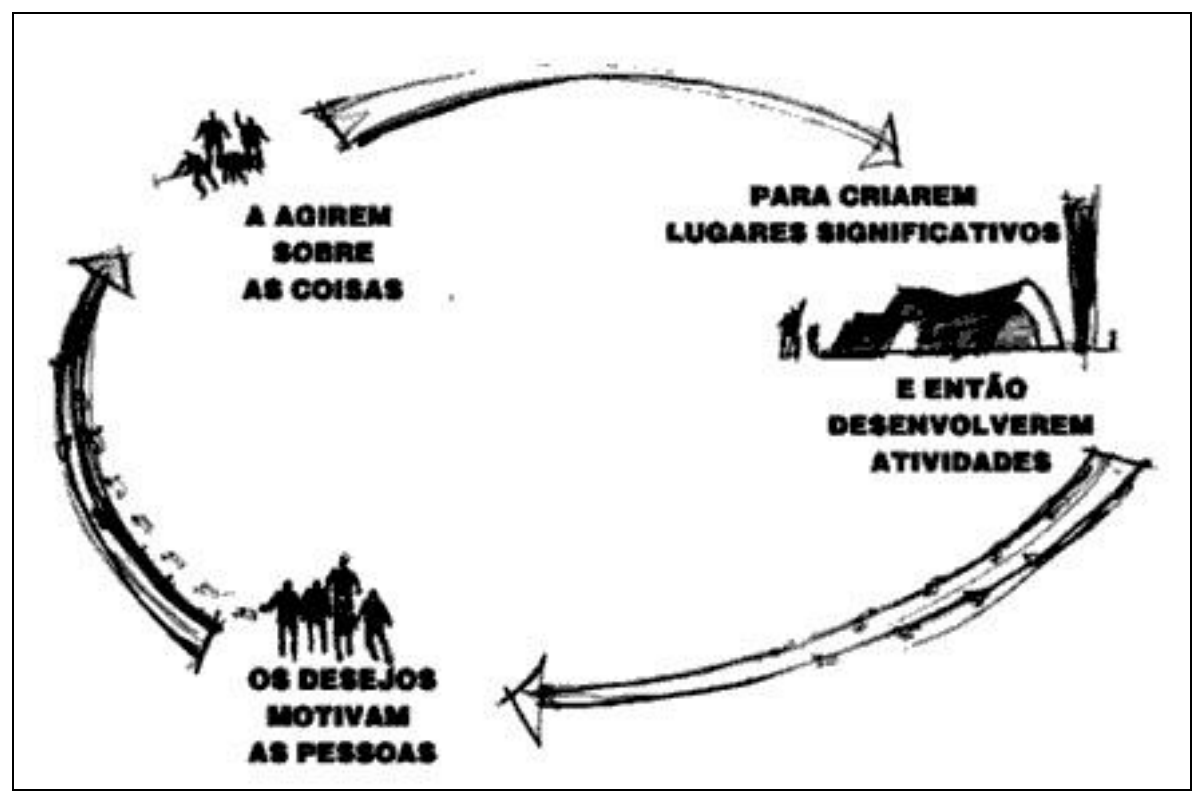

Figura 5: Diagrama da gênese do espaço arquitetônico. MALARD, 2006, p. 37.

A forma, concretizada no espaço é concebida com a combinação das linhas, pontos e das curvas, que por sua vez geram volumes. Essa composição ocorre baseada em princípios fundamentais de composição, como simetria, ritmo, proporção, equilíbrio, unidade e harmonia.

A simetria remete a uma noção de estabilidade para o homem, em razão da busca por essa estabilidade ela é encontrada em todos os campos do conhecimento, como na matemática e geometria, biologia e na área de estudo desse trabalho, a arquitetura. A simetria é estabelecida quando há uma divisão e esta resulta em partes iguais. Rohde (1982) a descreve como uma propriedade que um ente apresenta, quando o mesmo é submetido a uma operação específica. Para Rohde (1982, p. 9) “A simetria é uma operação que mantém uma forma invariante". Há 2000 anos o arquiteto romano, Vitruvio (2007, p.76) referiu-se à simetria como o "conveniente equilíbrio dos membros da própria obra e na correspondência de uma determinada parte".

Existem várias formas de arranjos simétricos, seja na natureza ou na arte e na 
arquitetura. Eles podem ser bilaterais, radiais ou axiais. A simetria bilateral é percebida quando posicionado um plano no centro de um corpo e ambas as partes fragmentadas são iguais, como na maioria dos animais, inclusive o homem. A simetria radial é encontrada principalmente na natureza, quando posicionado um eixo em um objeto, ou um animal e as partes giram em torno desse eixo.

Na prática arquitetônica, busca-se a simetria desde a antiguidade, atravessando vários estilos, em obras como o templo Partenon, em Atenas, a catedral metropolitana de Brasília, no Brasil, e a Villa Rotonda do arquiteto Andrea Palladio, com sua planta baixa obedecendo rigorosamente à simetria bilateral (Figura 06).

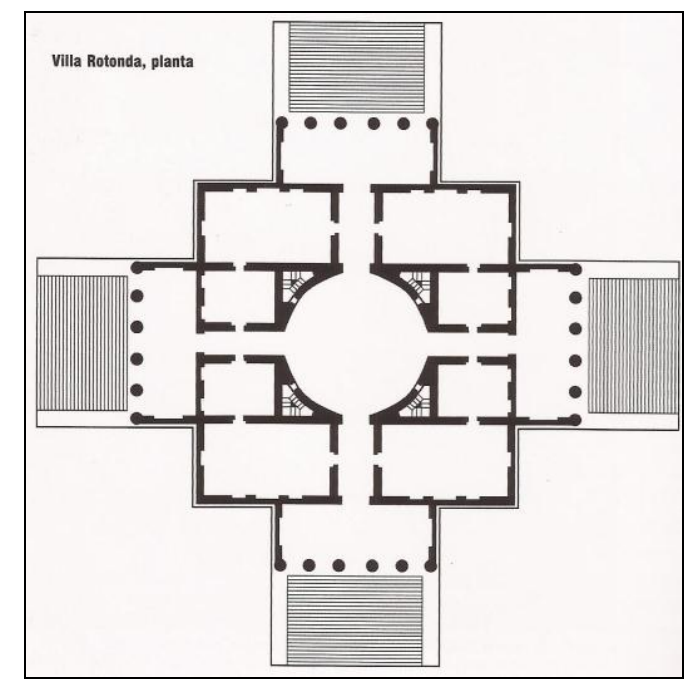

Figura 6: Planta baixa Villa Rotonda. Fonte: STRICKLAND, p.64.

Outro princípio da forma, utilizado na construção da arquitetura, é o ritmo. Ele também está contido na simetria, e é estabelecido a partir da repetição de elementos. Rodhe (1982) o descreve como um estado de equilíbrio. O ritmo, em quaisquer dos campos de conhecimentos, sugere ao homem conceitos de estabilidade e harmonia. Por isso, ele é amplamente utilizado na composição arquitetônica. O arquiteto brasileiro Oscar Niemeyer, utilizou o conceito de ritmo em várias de suas obras de arquitetura moderna, na capital de Brasília, como no palácio do Planalto (Figura 07), onde é possível visualizar a repetição ordenada dos pilares externos, compondo o ritmo da edificação. 


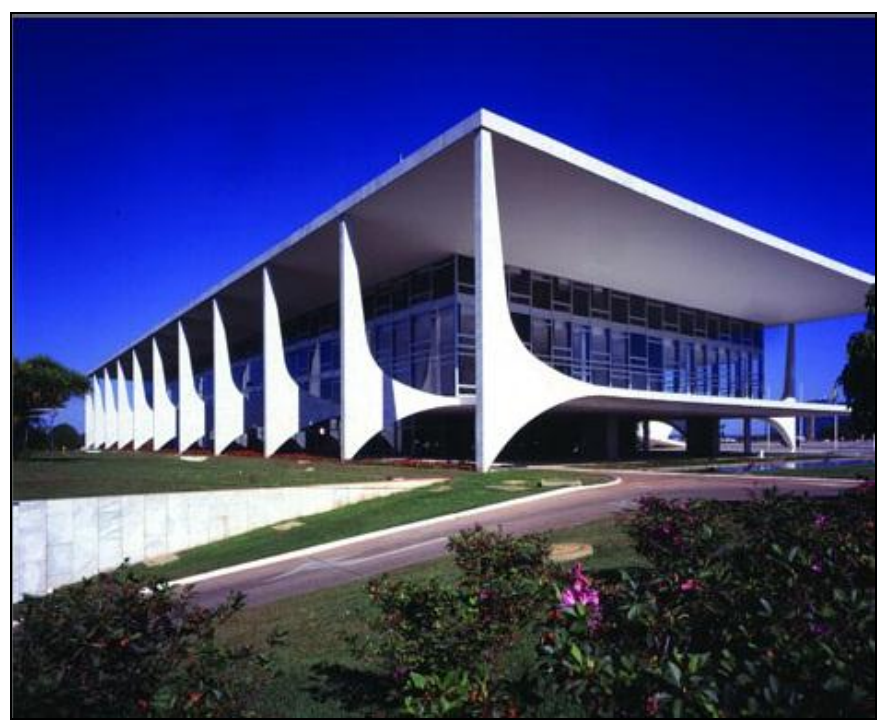

Figura 7: Palácio do Planalto. Fonte: Google Imagens. Disponível em: http://www.niemeyer.org.br/ Acesso em: 09 jul. 2011, 13:35.

O princípio do equilíbrio, assim como a simetria e o ritmo, está presente em todas as áreas do conhecimento humano. O homem sempre busca o equilíbrio, inclusive nas suas referências visuais. Para Gurgel (2007) o equilíbrio é encontrado quando os pesos visuais de dois elementos são iguais em relação a um eixo imaginário. Logo, eles se neutralizam. Essa noção de peso visual pode estar associada, obviamente, a visualização de elementos iguais em planos opostos, gerando o equilíbrio simétrico. Ou o equilíbrio pode ser encontrado com elementos diferentes em planos opostos, porém equivalentes em peso, configurando dessa forma equilíbrio assimétrico.

Construções equilibradas são construções harmoniosas. A harmonia na arquitetura é encontrada com a composição de elementos de forma sistematizada e racional e não uma combinação aleatória dos mesmos. Pode-se encontrar a harmonia, independente da simetria de uma edificação, pois o princípio harmônico é estabelecido por meio de proporções entre os espaços e elementos dentro da arquitetura.

Todos os conceitos de beleza para o homem, seja em objetos, em edifícios, ou no corpo humano, estão relacionados à proporção entre as partes que compõem o todo. A proporção é um princípio matemático relativo, pois refere - se, segundo Gurgel (2007, p. 32.) à "relação entre as partes de um todo; uma parte e um todo; ou entre um todo e outro todo".

Para Vitrúvio (2007, p. 168) a proporção “consiste na relação modular de uma determinada parte dos membros tomados em cada secção ou na totalidade da obra." Vitrúvio, 
arquiteto e engenheiro romano, viveu aproximadamente no ano de 25 a.C. Ele foi a primeira pessoa a sistematizar os estudos de proporção, criando uma analogia ao corpo humano, uma vez que descreve cada membro do corpo proporcionalmente à outro. Na arquitetura, essa proporcionalidade foi tida como vital nas construções gregas. Segundo Strickland (2003) as ordens gregas (dórica, jônica e coríntia) eram estabelecidas através de proporções matemáticas pré-estabelecidas. Proporções estas que foram exploradas nas construções, como o templo grego Partenon (Figura 08) considerado perfeito em sua proporcionalidade. O templo dedicado à deusa Atenas, possui todas as suas medidas estudadas matematicamente, o que, de acordo com Strickland (2003), lhe confere atributos de clareza, precisão e lógica.

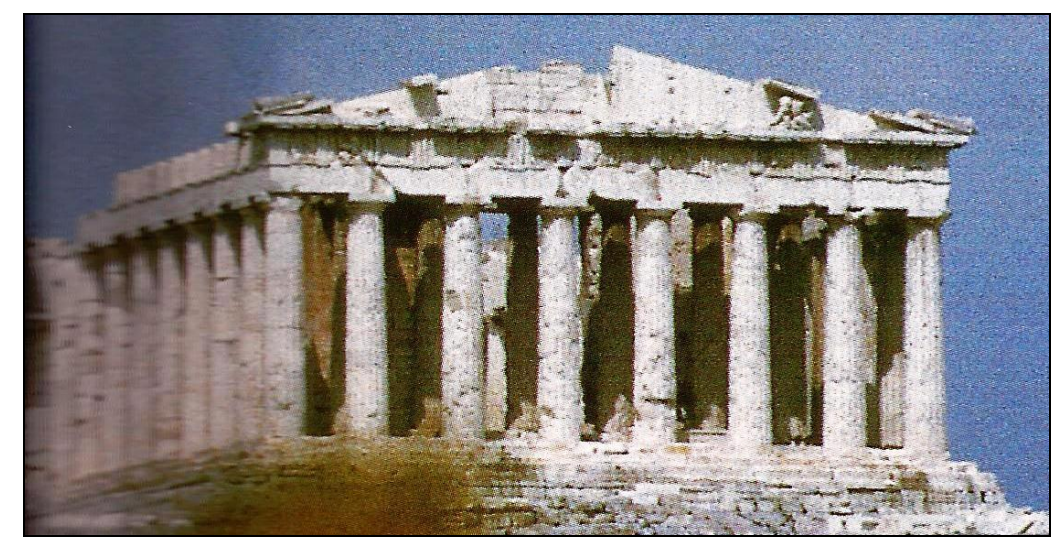

Figura 8: Partenon.

STRICKLAND, 2003, p. 13.

\subsection{PRINCIPIOS MATEMÁTICOS}

A proporção matemática em que o Partenon foi construído está presente em toda a história do planeta terra, desde a vida animal do período triássico, com os dinossauros, até a natureza e existência humana do atual período. Logo, foram muitas as mentes que se dedicaram a compreensão dessa proporção. De acordo com Ching (2005) ao decorrer da história da humanidade, existiram diversas teorias para estudar a proporção, e apesar de diferentes períodos e diferentes sistemas, os princípios e valores da proporção continuam os mesmos.

Considerado um dos grandes gênios da humanidade, Leonardo da Vinci realizou estudos relacionados à proporção encontrada no corpo humano, influenciado por Vitrúvio, que por volta de 25 a.C escreveu um conjunto de 10 livros, intitulado De Architectura. Vitruvio descreve no $3^{\circ}$ livro uma série de proporções encontradas nos membros do corpo do 
homem. Em meados do ano de 1490, Leonardo apresentou o homem vitruviano, o qual consistia de uma figura masculina, sem qualquer vestimenta ou adorno, em posição de braços abertos, formando a figura de um círculo e de um quadrado (Figura 09).

Após Vitrúvio e Leonardo, outros arquitetos vieram, posteriormente, a estudar as proporções. Os arquitetos renascentistas também exploraram as relações matemáticas na construção da forma arquitetônica. (CHING, 2005). Já na modernidade, no ano de 1948, o arquiteto suíço, conhecido como Le Corbusier, inspirado com as proporções encontradas no templo do Partenon, na Grécia, cria o modulor (Figura 10). O modulor consiste em uma espécie de sistema de medição, baseado em números matemáticos e no corpo humano, cujas medidas de referência são 113, 70 e $43 \mathrm{~cm}$, valores referentes a proporções matemáticas. (CHING, 2005). A partir dessas grandezas determinadas, o arquiteto suíço demonstra uma série de medidas que crescem em proporções contínuas. Le Corbusier utilizou seu modulor para compor suas obras de arquitetura modernas.

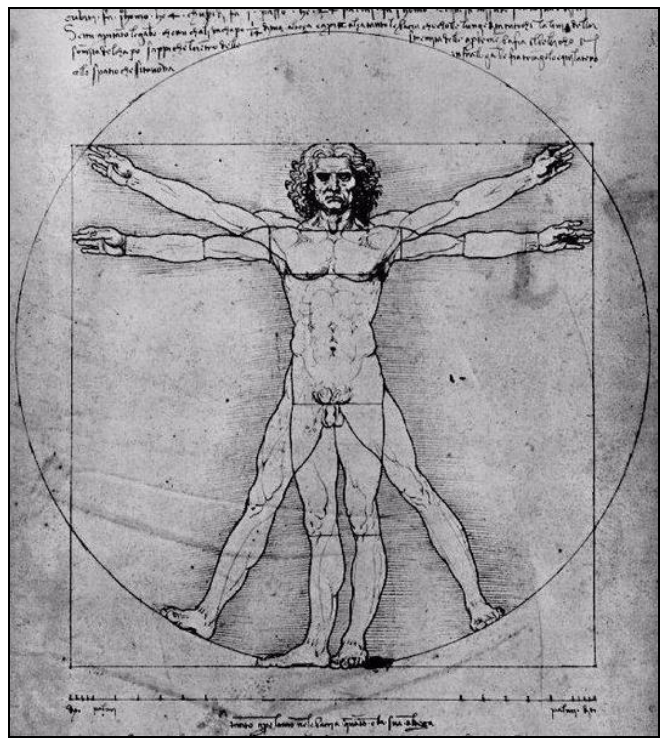

Figura 9: O homem vitruviano, de Leonardo da Vinci.

CESAR, p. 58.

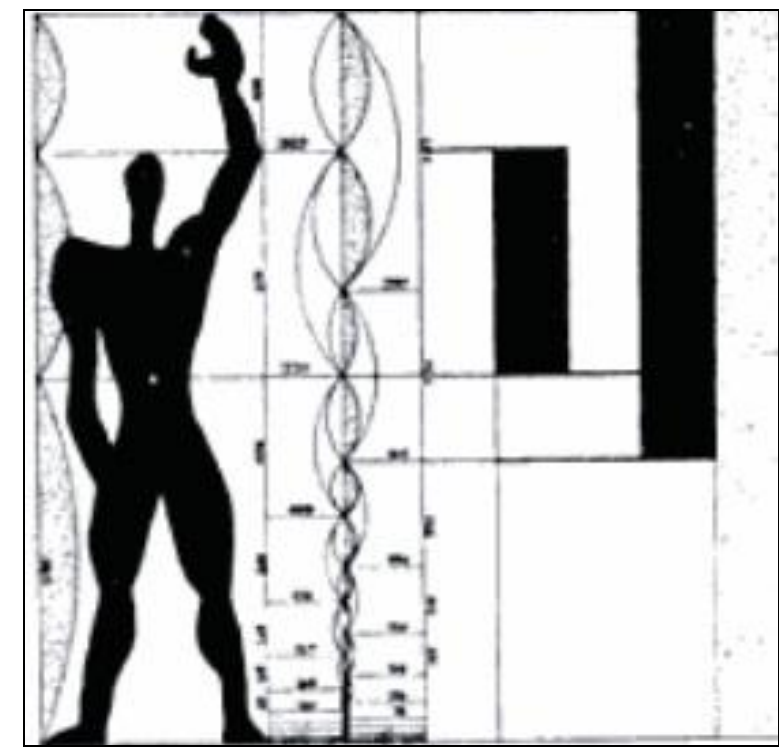

Figura 10: O Modulor, de Le Corbusier. KOTHER, p. 232.

De acordo com Doczi (2008) é possível encontrar unidade em todos os animais, vegetais e mesmo em coisas feitas pelo homem, através das proporções matemáticas e do crescimento dinâmico de alguns animais e vegetais. Esse crescimento consiste em uma relação constante baseada nos números 5 e 8 . Analisando pelo viés matemático, a razão entre esses números consiste em valores consideráveis, uma vez que o número 5 dividido pelo 
número 8 dá 0,625 ; também 8 dividido por $5+8(=13)$ dá por aproximação 0,625 . A razão contrária desses números também segue um padrão, 8 dividido por 5 é 1,625, ou seja, um valor igual ao resultado obtido na primeira operação, acrescidos de uma unidade. (DOCZI, 2008.)

Por meio da análise dessas operações, chega-se a seguinte equação, chamada de secção áurea: A: B = B: (A+B) (Figura 10). Para Doczi (2008, p. 2) esta equação é "a singular relação recíproca entre as duas partes desiguais de um todo, na qual a parte menor está para a maior assim como a parte maior está para o todo". Para Ching (2005, p. 286) "a secção áurea poder ser definida como a razão entre duas secções de uma reta, ou duas dimensões de uma figura plana, em que a menor das duas está para maior assim como a maior está para a soma de ambas". O interessante refere-se ao fato de que somente em um ponto de uma superfície, ou linha, ela poderá ocorrer. Esse ponto é chamado de o ponto de ouro. (DOCZI, 2008.)

Essa proporcionalidade é encontrada em praticamente toda a natureza e na vida animal. A humanidade também busca ao longo dos séculos essa proporção, em praticamente todos os objetos, criados pelo homem, a exemplo do cartão de crédito, e cheques, nos quais a sua forma é representada pelo retângulo áureo, de 5 por 8. (DOCZI, 2008).

O crescimento dinâmico de vegetais, como a flor do girassol (Figura 11), também está ligado a uma sequência de números, conhecida como a série Fibonacci, descoberta por Leonardo de Pisa, aproximadamente no período de 1200 . Na série, $(1,2,3,5,8,13,21,34,55 \ldots)$, cada número dividido pelo número seguinte dará aproximadamente 0,618 . Ao contrário, cada número dividido pelo anterior dará o resultado de 1,618. Esses números correspondentes respectivamente, a parte maior e menor da secção áurea.

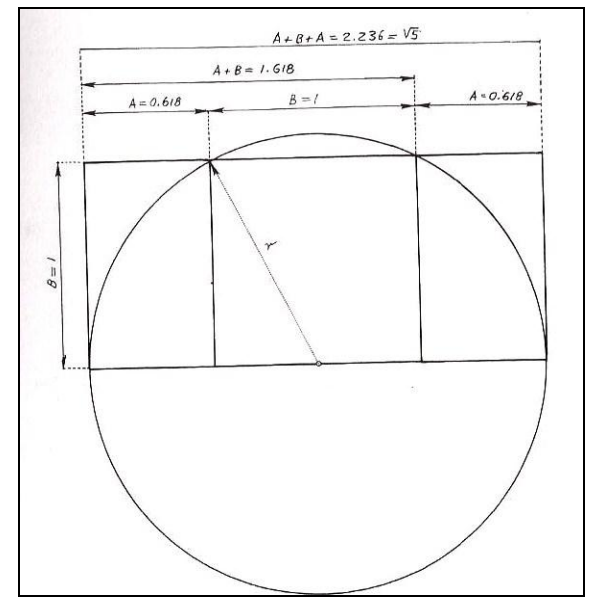

Figura 11: Construção clássica da secção áurea. DOCZI, 2008, p. 03. 


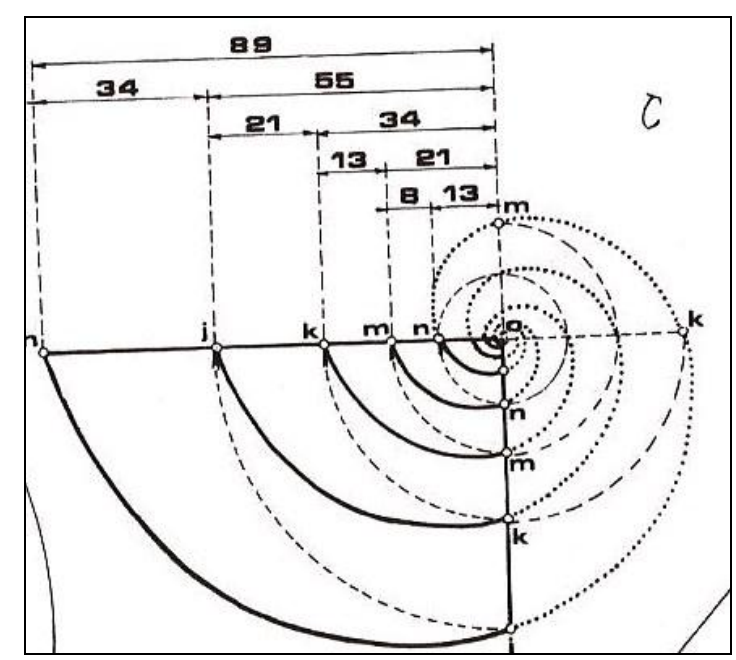

Figura 12: Espirais da semente de girassol. DOCZI, 2008, p. 04.

Outra relação, pertinente à arquitetura, refere-se aos triângulos retângulos, cujos lados também contêm as relações áureas descritas acima. O triângulo retângulo, conhecido também como triângulo de Pitágoras, possui em seus lados, unidades numéricas relativas aos números 3, 4 e 5. No qual 3 e 5 possuem $90^{\circ}$ de angulação entre eles e 5 é o valor da hipotenusa. Os números 3 e 5 estão na sequência de Fibonacci.

Essas relações matemáticas são encontradas não só na natureza e nos animais, mais também nas construções humanas. Desde povos pré-históricos busca-se a proporção áurea. Como no grande monumento feito em pedra, na arcada de Stonehenge, na Inglaterra (Figura 13 e 14), construído por volta de 2000 a 1600 a.C. (DOCZI, 2008), e nas pirâmides do México, como a pirâmide Chichen Itza, onde é possível visualizar em sua configuração as figuras do triângulo retângulo.

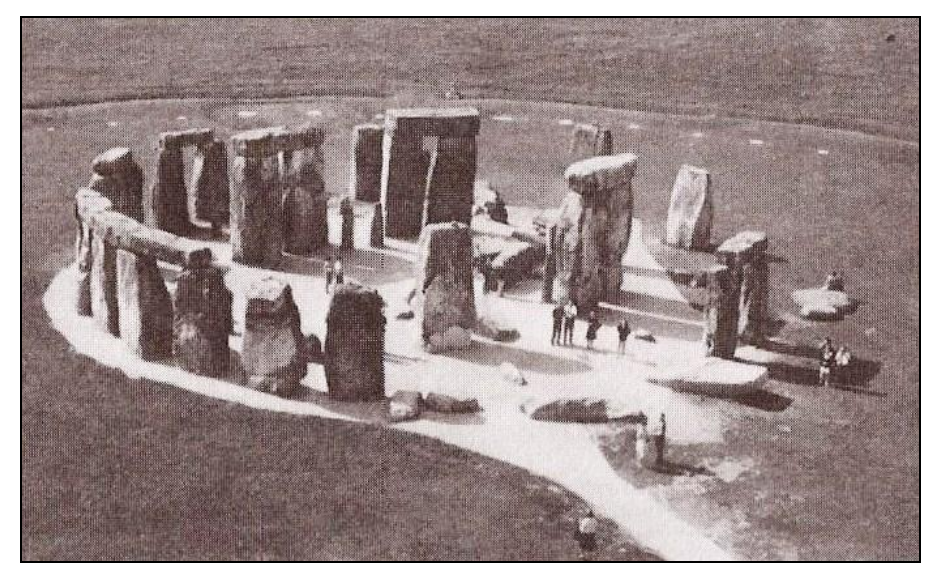

Figura 13: Stonehenge.

DOCZI, 2008, p. 39. 


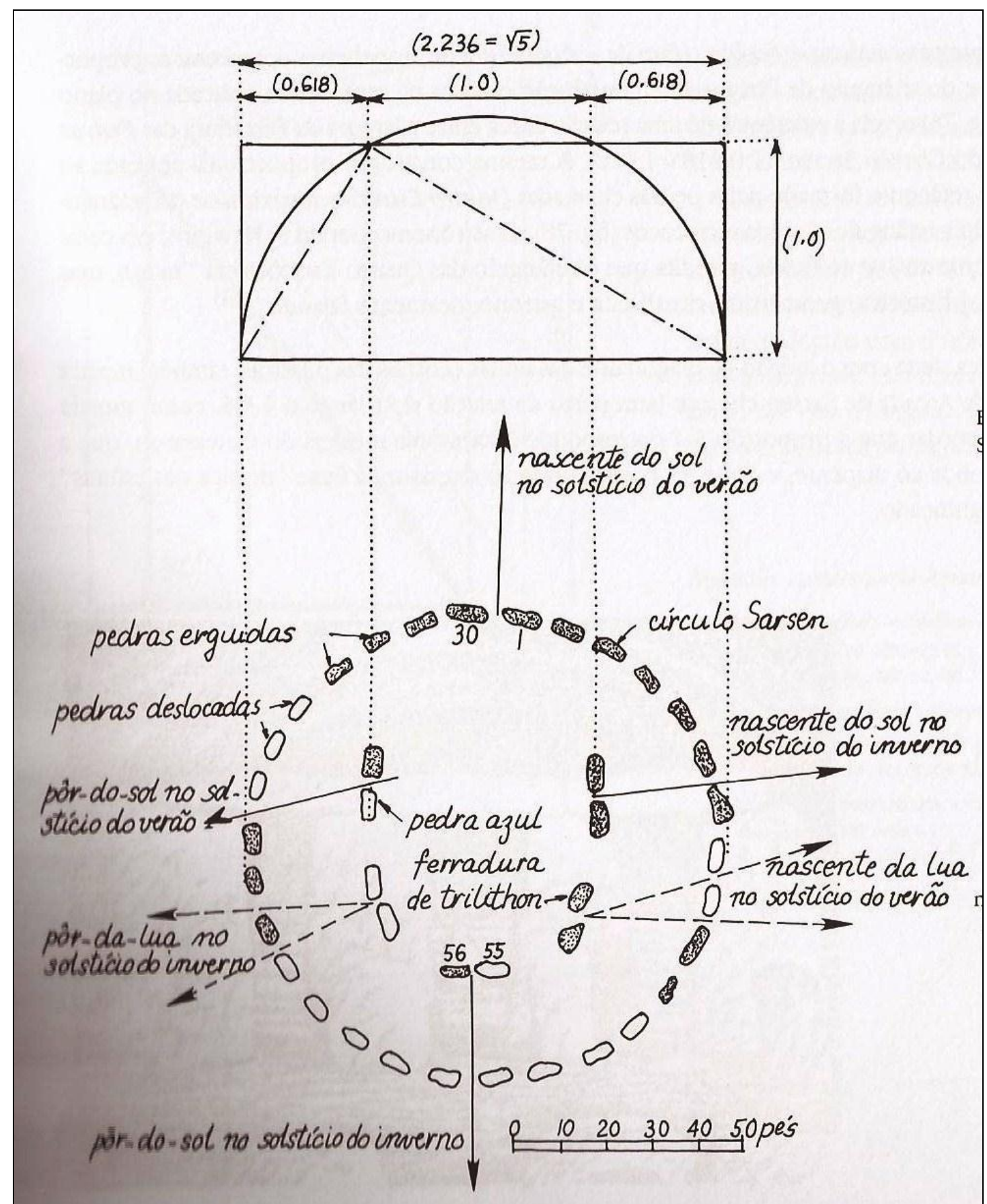

Figura 14: Estudo do alinhamento de Stonehenge. DOCZI, 2008, p. 39.

\subsection{A CONSTRUÇÃO DA FORMA NA ARQUITETURA}

\subsubsection{A ARQUITETURA A PARTIR DO MOVIMENTO MODERNO}

A modernidade arquitetônica em emergência no fim do século XIX e início do século XX mudou radicalmente a construção da forma na arquitetura. A concepção arquitetônica 
seguia um padrão classicista, já estabelecido desde a antiguidade, baseado em cânones clássicos e tipologias historicistas. De acordo com Curtis (2008) a arquitetura moderna possibilitou um novo debate acerca dos princípios básicos da arquitetura, fundados na simplicidade dos elementos e na clareza das idéias formais, criando uma ruptura sem precedentes na composição arquitetônica. Não porque os arquitetos do período moderno fossem contra a tradição, e sim porque eles eram contra o academicismo, instituído pela École des Beaus Arts de Paris. É fato que eles estudaram grandes teóricos do século passado, porém, segundo Pevsner (2002) a partir dos anos 1900 a questão estava relacionada à problemática da transformação de toda tradição existente em uma linguagem moderna, voltada para arte mecânica. De acordo com Piñon (2006, p. 22) "a modernidade instituiu um modo de entender a forma que substitui o impulso de mímeses pelo de construção”. Logo, a partir do movimento moderno é possível visualizar uma divisão na concepção formal.

A modernidade arquitetônica surgiu e se desenvolveu devido a uma série de acontecimentos, que serão brevemente explicados a seguir, pois são peças importantes para a compreensão do movimento moderno, assim como o conhecimento acerca da produção de alguns arquitetos, que ao longo da primeira metade do século $\mathrm{XX}$, se tornaram figuras essenciais nessa transição formal da arquitetura, e sem os quais o movimento moderno não seria completo. Para Curtis $(2008$, p. 275) "há outro nível de compreensão que deve ser alcançado caso se queira entender o significado interno de uma nova tradição. Ele está na química intelectual especial da obra individual de alto padrão. E nesse caso, nos interessa o sítio, o contexto e as intenções que forem únicos".

De acordo com Frampton (2008), quando mais se busca a origem da arquitetura moderna, mais dar-se conta de que ela está atrás, em meados do século XVII. É impossível compreender o modernismo, sem conhecer o contexto histórico instaurado com o declínio do classicismo, e o desenvolvimento de inovações tecnológicas realizadas no século XIX. Para Curtis (2008) o surgimento da modernidade foi uma reação que a sociedade teve ao caos e ecletismos que nela se instalou, devido a várias tentativas de revivais de modelos históricos.

Esse processo de transformação estética tornou-se de fato visível, na segunda metade do século XIX, quando a Revolução Industrial transformou o modo de fabricação dos artefatos e produtos criando a produção em massa, através das máquinas em substituição ao trabalho humano. Todavia, o desenvolvimento da produção industrial e das tecnologias produtivas não pode ser analisado somente como uma inovação desse processo de produção. 
É impossível, referir-se à Revolução Industrial sem levar em consideração o desejo de transformação da sociedade.

No início do século XX, o pensamento vigente da população acompanhava a crescente industrialização e inovação tecnológica, fato esse, que motivou a busca pela renovação das artes em oposição aos historicismos. Para Benevolo (2001), desde 1890 a cultura artística tradicional enfrentava um período de crise. Em razão disso, logo surgiram movimentos artísticos, no fim do século XIX, questionando o papel da arte na sociedade e buscando novas formas para a arquitetura. O primeiro deles, o Arts \& Crafts surgiu na Inglaterra, país pioneiro da Revolução Industrial, cuja industrialização precoce culminou no clima propício a transformações estéticas. Outro movimento artístico precursor do movimento moderno nasce na Bélgica, de acordo com Benevolo (2001), e chama-se Art Noveau. Tanto o Arts \& Crafts quanto o Art Noveau apresentavam o início do que viria a ser tornar, posteriormente, as artes e arquitetura no cenário mundial.

A partir desse cenário de crescente industrialização e levando em consideração as transformações do modo de vida, surge no início do século XX, o movimento moderno. Um novo período para as artes e arquitetura, caracterizado pela modernidade em oposição ao classicismo vigente. Piñon (2006) defende que o modernismo, deve ser entendido como uma nova maneira de se conceber arquitetura e não a um desgaste estético do classicismo. Tampouco, se deve resumir o movimento a um conjunto de características. Piñon (2006) o define como uma mudança em relação ao modo de construção da forma, enquanto representação arquitetônica. Para Frampton (2008) a construção da forma na arquitetura moderna rompeu com a arquitetura clássica, uma vez que estabeleceu como sujeito principal da construção, componentes técnicos, dentre eles escadas, rampas, elevadores. Componentes estes que na arquitetura clássica estavam escondidos, agora se tornaram elementos principais da representação funcional da nova arquitetura.

Logo, a representação da arquitetura, o espaço onde se desenvolvem as atividades humanas, é visto a partir de então, como uma representação do novo estilo de vida do homem moderno e as formas da arquitetura devem então abrigar essa nova filosofia. Para Scully (2002), o homem do início do século XX, encontrava-se em tensão, devido ao rompimento do modo de vida antigo, e a arquitetura moderna deveria então, refletir esse estado mental. 


\subsubsection{O DESENVOLVIMENTO DA ENGENHARIA ATRAVÉS DO CONCRETO ARMADO}

Grande parte dessa transformação arquitetônica só foi possível devido ao surgimento de um novo material da construção civil, o concreto armado, cujo desenvolvimento se deu devido à baixa resistência à tração do concreto simples. A nova tecnologia une a alta resistência à compressão e durabilidade do concreto com a alta resistência á tração do aço (liga metálica de ferro e carbono). Logo, diferente do concreto, que é uma espécie de pedra artificial, composta de cimento, água e agregados (BOTELHO, MARCHETTI, 2002) a qual, suporta apenas esforços de compressão, o concreto armado é resistente também aos esforços de tração, devido à introdução do aço em sua constituição.

O desenvolvimento do concreto simples aconteceu por volta de 1774, na cidade de Cornwall, na Inglaterra, quando o engenheiro John Smeaton realizou uma série de experimentos para encontrar o material construtivo que aguentaria sustentar o farol de Eddystone (Figura 15). Após diversas tentativas, ele por fim, utilizou uma mistura composta de cal, argila, areia e escória britada de ferro, para construir a base do seu farol. Porém, apesar da liderança inicial na tentativa do concreto armado, não foi a Inglaterra que seguiu com o desenvolvimento do mesmo.

A partir desse período, a técnica construtiva começa a evoluir, abrindo espaço para novos usos da mesma. A França, devido às condições econômicas, associadas ao costume de se construir em terra pisada, e ao desenvolvimento do cimento hidráulico pelo engenheiro Louis Vicat, em 1800, foi o primeiro país a inventar o concreto armado. O primeiro construtor a utilizá-lo, foi François Coignet que em 1847, projeta um terraço, com a cobertura em concreto e ferro. Em seguida, Joseph Louis Lambot projeta uma embarcação (Figura 16) e em 1861 Coignet desenvolve uma nova técnica, que consistia em reforçar o concreto com tela metálica.

O concreto armado também era aplicado em vasos de flores, patenteados em 1849, por Joseph Monier, importante paisagista da época, também francês. Nessa fase, o novo material era utilizado somente em pequena escala, e geralmente na decoração, como texturas em paredes. Porém, os arquitetos começaram a utilizá-lo nas construções, pois ele trazia vantagens econômicas e era de fácil aplicação. O primeiro construtor a utilizar o concreto armado em uma casa, foi o americano William E. Ward, em 1873, nos Estados Unidos. (FRAMPTON, 2008). Depois dele, a técnica foi utilizada em um prédio, por August Perret, A 
edificação, localizada em Paris, é finalizada em 1903 e trata-se da primeira construção onde é possível visualizar pelo exterior, o uso do concreto armado, (BENEVOLO, 2001).

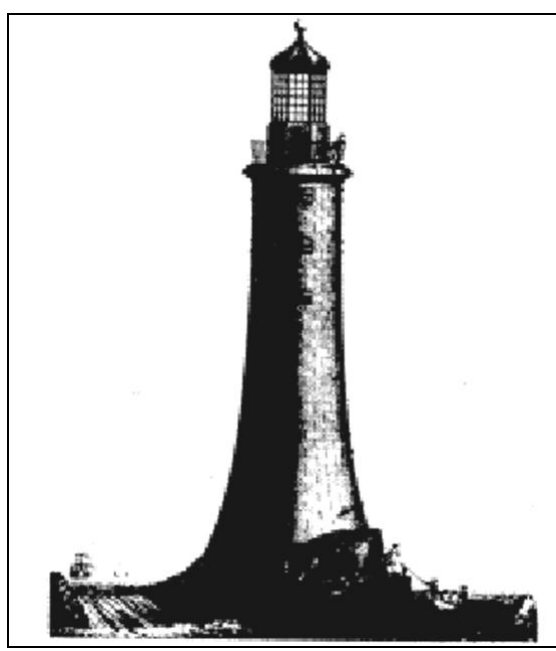

Figura 15: Farol de Eddystone. Fonte: Google Imagens. Disponível em: http://www.cimento.org/site/concreto.html. Acesso em: 31 jul. 2011, 15:14.DOCZI, 2008, p. 03.

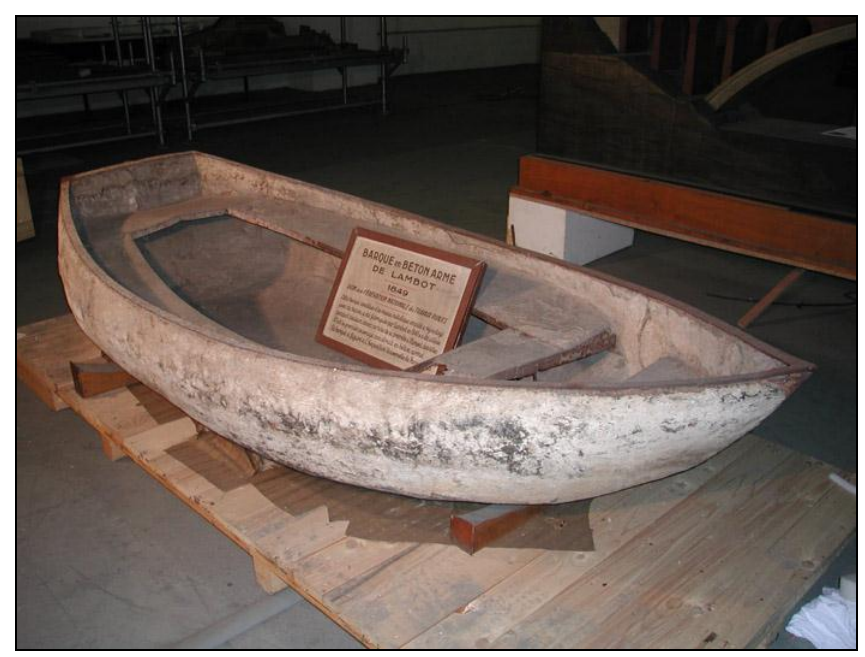

Figura 16: Primeira embarcação construída em concreto armado.

Fonte: Google Imagens. Disponível em:

http://www.expositions-universelles.fr/1855-expositionuniverselle-paris.html.

Acesso em: 22 jul. 2011, 18:09.

A introdução do concreto armado no mercado construtivo complementou a arquitetura moderna, pois sem ele os grandes precursores do modernismo não poderiam projetar suas obras. O uso em conjunto desses materiais, o concreto simples ao aço, garante a durabilidade da estrutura, uma vez que o cimento protege o aço da oxidação. $\mathrm{O}$ concreto armado traz também uma grande vantagem quanto à adaptabilidade, pois seu uso viabiliza formas arquitetônicas mais ousadas, que não seriam possíveis com o uso do concreto simples. Por isso, ele foi amplamente utilizado no século XX, e se tornou elemento essencial à prática da arquitetura moderna.

\subsubsection{LE CORSBUSIER: SISTEMA DOM-INO E OS CINCOS PONTOS PARA UMA NOVA ARQUITETURA}

Le Corbusier foi uma figura de extrema importância para a modernidade, pois em toda sua produção arquitetônica procurou representar o mundo mecanizado, através da aliança entre a arte e a máquina. Ao longo de sua vida sempre esteve em contato com as vanguardas tecnológicas, e foi introduzido às possibilidades construtivas que o concreto armado podia oferecer durante as viagens que realizou pela Europa. 
Le Corbusier saiu da Suíça em 1907 e foi morar na França, onde conheceu importantes arquitetos, como Tony Garnier, e trabalhou com August Perret, que já utilizava o concreto armado. Em seguida, viajou para a Alemanha, onde absorveu conhecimento com Peter Behrens, com quem trabalhou também, e Heinrich Werkbund, arquitetos que como Perret, conheciam as técnicas de engenharias modernas. Em 1911, o arquiteto suiço viaja para Itália, Grécia e Ásia menor, em uma viagem que chamou de "Voyage d'orient'. Nessa peregrinação, visitou o Partenon, e ficou impressionado com a proporção e ordem da edificação na Acrópole de Atenas, passando a partir de então, a desenvolver formas em vinculo com proporções matemáticas. (CURTIS, 2008).

Le Corbusier primou durante sua vida pela aliança entre engenharia e arquitetura. Em seu livro "Por uma arquitetura", ele escreve sobre o engenheiro e sobre o arquiteto:

O engenheiro, inspirado pela lei de economia e conduzido pelo cálculo, nos põe em acordo com as leis do universo. Atinge harmonia.

$\mathrm{O}$ arquiteto, ordenando formas, realiza uma ordem que é pura criação de seu espírito, pelas formas afeta intensamente nossos sentidos, provocando emoções plásticas; pelas relações que cria, ele desperta em nós ressonâncias profundas, nos dá a medida de uma ordem que sentimos em consonância com a ordem do mundo, determina movimentos diversos de nosso espírito e de nossos sentimentos, é então que sentimos a beleza. (LE CORBUSIER, 1926, p. 3).

Após o conhecimento adquirido, volta para França e desenvolve em 1915, em parceria com Max du Bois, um novo sistema construtivo, o sistema Dom-ino (Figura 17) concebido através de uma estrutura independente de vigas apoiadas em pilares. Le Corbusier persiste com a idéia de uma pureza estrutural, criando formas precisas e que pudessem ser padronizadas, buscando desse modo, a universalidade de sua obra. Assim, o arquiteto encontrou na geometria o seu principal critério compositivo, e os dimensionamentos do sistema Dom-ino foram concebidos com base na secção áurea. Com o sistema, ele poderia encontrar liberdade projetual na fachada. Le Corbusier projeta uma estrutura simples, que pode se adaptar a diferentes programas e ser reproduzida em larga escala, mostrando a economia da construção. O sistem Dom- Ino é o precursor do estilo formal de Le Corbusier, que em seguida, estaria presente nas obras do arquiteto suíço, e mudaria a representação formal da arquitetura a partir de então. 


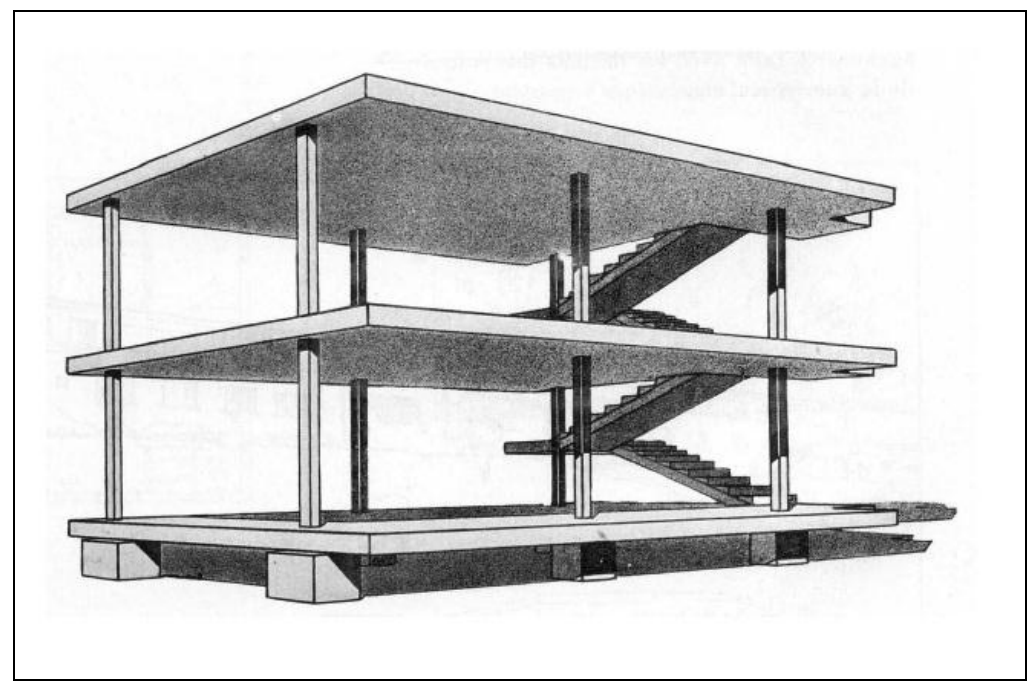

Figura 17: O sistema Dom-ino.

CURTIS, 2008. p. 85.

Em 1916, August Perret apresenta o pintor Amédée Ozenfant à Le Corbusier, e juntos desenvolvem o Purismo, em um manifesto intitulado "Aprés le cubisme". Diferente do movimento de Picasso, o purismo primava por uma ordem e precisão matemática, em favor de uma arte objetiva. Segundo Curtis (2008) essa etapa da vida de Le Corbusier foi de profunda importância para sua carreira como arquiteto, pois o período em que se dedicou a pintura foi uma espécie de laboratório de formas. Já em 1920, em Paris ele adota o pseudônimo de Le Corbusier, deixando de lado seu nome Jeanneret, e cria, em sociedade com Ozenfant a revista " $L$ 'espirit noveau". Le Corbusier ansiava pelo rigor matemático encontrado em formas primárias e os estudos que desenvolveu com Ozenfant foram de extrema importância para a construção da sua identidade formal, construída através das idéias puristas.

Nesse período, ainda em busca da forma ideal, Le Corbusier desenvolve novos critérios adotados para a prática da arquitetura. Ele acreditava que a arquitetura deveria ser desprovida de qualquer adorno ou decoração, cumprindo ao máximo a funcionalidade. Segundo Le Corbusier (1981, p. 65) “a casa era uma máquina de morar”. Em 1926, de acordo com Frampton (2008), após o sistema Domi-ino, como uma espécie de extensão do mesmo, Le Corbusier estabelece características que a construção deveria oferecer ao homem moderno. Essas orientações ele denominou "cinco pontos de uma nova arquitetura" e eram compostas pelos seguintes componentes formais: 


\section{Pilotis}

A casa agora era elevada do solo, através dos pilotis, deixando assim o térreo da edificação livre, para tráfego dos automóveis. Para Le Corbusier, esse era o princípio básico da sua doutrina, pois ele visualizava uma cidade toda elevada para livre utilização dos carros.

\section{Planta livre}

Uma vez que não precisariam mais de paredes internas como apoio a estrutura, a planta poderia ser livre para adaptar-se às exigências dos clientes.

\section{Fachada livre}

Le corbusier pregava a fachada livre, pois do mesmo modo que a planta, os pilotis deixavam a fachada livre, e esta deveria ser desprovida de qualquer decoração.

\section{Janelas em fita}

Outro quesito a ser cumprido para Le Corbusier eram as janelas em fita. As aberturas da edificação deveriam estender-se de um lado á outro da construção, como se fossem fitas ao longo das paredes, dando uma sensação de leveza a conjunto.

\section{Terraço jardim}

Por fim, o terraço jardim. Com o sistema estrutural do concreto armado, a última laje da edificação poderia ser também um ambiente de convívio, e este deveria conter a área arborizada da residência, como a reproduzir o terreno que existia antes da construção da casa.

Le Corbusier utilizou seus princípios em todas as obras que realizou em seguida. Como na casa Cook (Figura 18) sendo o volume composto basicamente por um cubo, com janelas em fita. Aqui é possível visualizar a clareza da forma de Le Corbusier e o equilíbrio assimétrico, constituído pela sacada a esquerda. O arquiteto descreve a casa Cook como o resultado das certezas que tinha até então, em relação aos cinco pontos para uma nova arquitetura. 


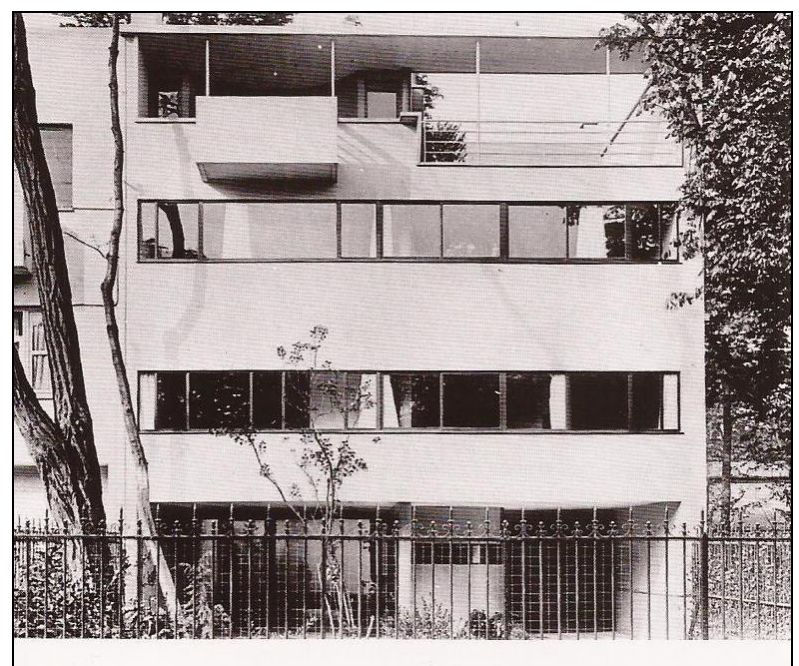

Figura 18: Casa Cook. CURTIS, 2008. p. 175.

A obra de Le Corbusier que sintetiza todas as suas teorias desenvolvidas ao longo de sua carreira, até o fim da década de 20, é a Ville Savoye (Figura 19 e 20). Uma casa de campo localizada a $30 \mathrm{~km}$ de Paris, na cidade de Poissy, construída em 1929. A Ville Savoye é envolta por um vasto campo verde, onde primeiro se visualiza a caixa retangular branca sobre os pilotis, e as janelas percorrendo um lado a outro da casa. Na fachada posterior, é possível enxergar a curva em cima da caixa retangular. Le Corbusier responde ao mundo mecanizado ao projetar essa residência, pois no seu entendimento a casa era também uma máquina. $\mathrm{Na}$ Ville Savoye é possível ver os componentes técnicos da construção, a escada e a rampa ocupando um lugar de destaque na planta livre. Para Curtis (2008, p. 280) "a ville savoye pode ser vista como um equivalente arquitetônico das transparências, simultaneidades e ilusões da pintura cubista”.

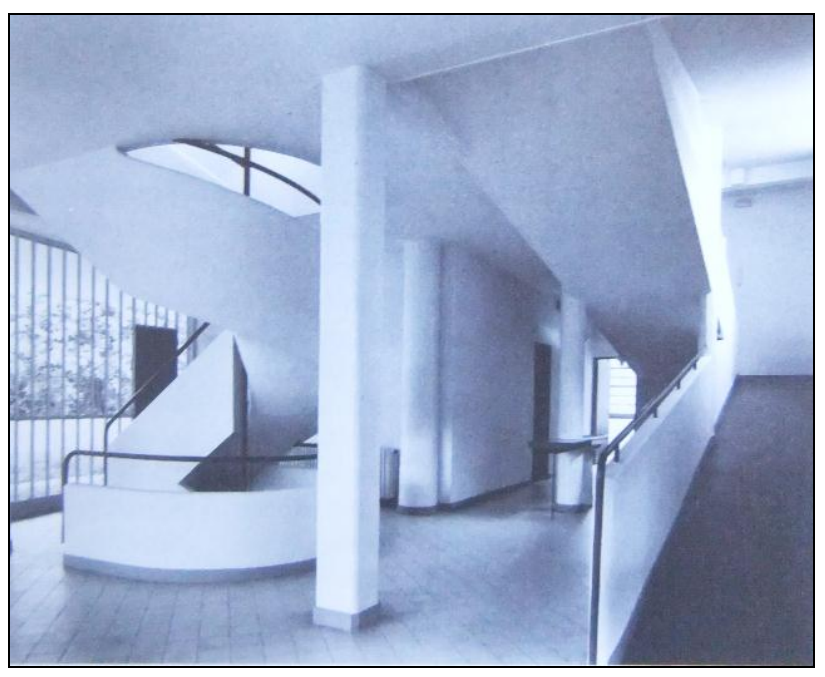

Figura 19: Ville Savoye. CURTIS, 2008. p. 277.

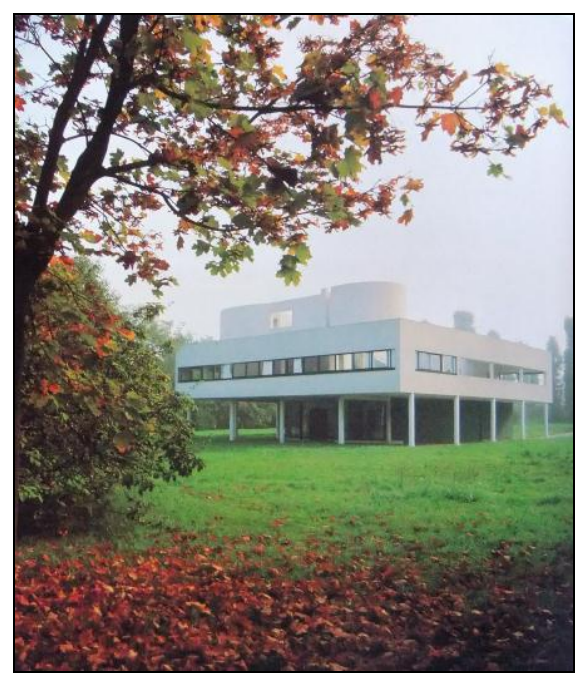

Figura 20: Ville Savoye. CURTIS, 2008. p. 276. 


\subsubsection{BAUHAUS}

A Bauhaus foi um acontecimento notável na modernidade arquitetônica, não só para a construção da forma na arquitetura, mais para a estética de todas as artes, inovando o ensino da arte a partir de então.

Diante do contexto de transformação do modo de vida, e associado ao fim da Primeira guerra mundial, que resultou em uma autocrítica da sociedade pelos intelectuais alemães, (ARGAN, 1999) encontra-se a Alemanha, onde em 1918 surge a Bauhaus, primeira escola de arquitetura moderna, fundada por Walter Gropius, na cidade de Weimar. A Bauhaus trouxe inúmeras inovações do modo de se ensinar e produzir arquitetura. Foi a primeira escola democrática, de acordo com Argan (1999), pois baseava-se na colaboração mútua entre alunos e professores. A palavra Bauhaus significa "casa da construção.” Gropius desejava unir artes, artesanato e indústria, para ele tudo deveria ser funcional e padronizado. Apesar do racionalismo, a Bauhaus sempre primou pelo exercício criativo e esteve em contato com outros movimentos artísticos europeus. Gropius queria antes de tudo, conceber formas puras e racionais, desprovidas de cânones do passado. No início do curso, os alunos não tinham aulas de história, para não sofrerem influências na hora da criação do projeto.

A sede da escola mudou de Weimar para Dessau, em 1925, devido a um novo arranjo político. Em 1928 Gropius transfere a diretoria da Bauhaus para Hannes Meyer. O crescimento político da direita ia de encontro aos interesses e ideais de Meyer, que logo é obrigado a abandonar a escola em 1930. Com isso, tem-se a última fase da escola, refugiada em Berlim, devido à perseguição dos nazistas. A partir de 1932, Mies Van der Rohe assume o comando e permanece diretor por mais um ano, até 1933, quando a escola é fechada pelos nazistas. Apesar da existência da Bauhaus não ter sido tão longa, os efeitos que ela trouxe para a construção formal da arquitetura foram notáveis. Para Argan (2001) as pesquisas analíticas da escola, influenciaram a produção industrial em série de vários objetos de uso geral utilizados atualmente, como móveis em tubos metálicos, e luminárias.

\subsubsection{A CONSTRUÇÃO DA FORMA ATRAVÉS DO MOVIMENTO NEOPLASTICISTA}

Em 1917, o artista plástico e arquiteto holandês Theo Van Doesburg cria o movimento artístico, conhecido como o Neoplasticismo (Argan, 1999), o qual posteriormente ficou conhecido como De Stijl, quando Theo Van Doesburg e Piet Mondrian fundaram a revista De 
Stijl (O Estilo). Os neoplasticistas almejavam uma renovação estética de todas as artes, através do racionalismo, pois acreditavam que, com isso, poderiam mudar a sociedade, tendo em vista uma cultura universal. Promoviam a necessidade do equilíbrio entre universal e individual. O movimento traz consigo o desprezo pelo ornamento em suas edificações. Para os neoplasticistas a forma deveria ser pura, logo, eles utilizavam linhas e ângulos retos, e cores primárias (amarelo, vermelho e azul) associadas ao branco, preto e cinza. A forma arquitetônica neoplasticista desprezava a simetria, por se tratar de um dos princípios utilizados na antiguidade e no classicismo. O movimento teve influencia sobre todas as áreas da arte, devido à diversidade artística dos integrantes do movimento, muitos deles pintores, como Mondrian e Bart Van der Leck, e designers, como Gerrit Rietveld.

O movimento teve a curta existência de 14 anos, e foi marcado pela influência, segundo Frampton (2008) de três figuras, o matemático Schoenmaekers, que criou o termo neoplasticismo, e a restrição à utilização das cores primárias. Porém, apesar de ter criado os fundamentos do De Stijl, não desempenhou participação direta no desenvolvimento estético do movimento. O neoplasticismo sofreu influência inicialmente do organicismo de Frank Loyd Wright e em maior intensidade do arquiteto holandês, Hendrik Berlage, devido a sua crítica sociocultural e ao uso racional dos elementos construtivos.

Em relação à construção da forma arquitetônica do século $\mathrm{XX}$, o neoplasticismo traz semelhanças às pinturas geométricas de Piet Mondrian, composições que consistiam na maioria em linhas horizontais e verticais quebradas. Após seu isolamento devido a guerra, Mondrian estabelece novas composições, com planos retangulares, flutuantes e coloridos. (FRAMPTON, 2008).

Entretanto, o movimento não teve grandes representações na arquitetura logo no início, apesar da existência de uma obra arquitetônica (Figura 21) relacionada ao movimento, em 1916, construída por Robert van’t Hoff em concreto armado, ainda com forte influência de Wright, (BANHAM, 1975.) 


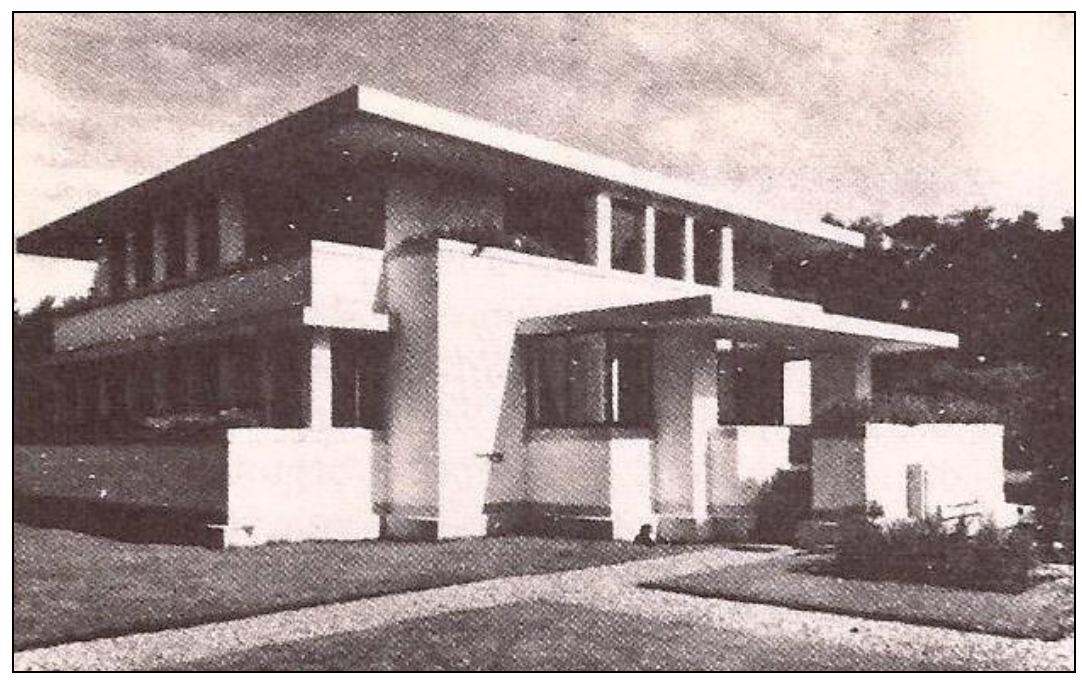

Figura 21: Villa em huis ter Heide, de Rob van t'Hoff. Fonte: BANHAM, p. 244.

De fato, a primeira aparição de elementos neoplasticistas em três dimensões deve-se a Gerrit Rietveld, com a construção da cadeira vermelha/azul. Após a cadeira, Rietveld continuou com a produção de peças de mobília até meados dos anos 20.

Em 1921, poucos integrantes do inicio do movimento ainda continuam, e novos aderiram. Inicia-se a segunda fase do movimento que vai até 1925 e marca o período de disseminação internacional do movimento. A partir dessa etapa as obras de Van Doesburg são influenciadas pelo artista russo Lissitzky.

Na Holanda, o movimento seguia com Rietveld e Vilmos Huszar, pintor húngaro que desenhou a primeira capa da revista $D e$ Stijl. Rietveld nesse período iniciou o projeto da Casa Schroder, em Utrecht (Figura 22, 23, 25, 25). A residência era a realização dos Dezesseis pontos de uma arquitetura plástica, de Van Doesburg. Apesar da construção tradicional em madeira e tijolos, a casa tornou-se ícone do neoplasticismo, pois se enquadrava em todos os aspectos da nova arquitetura. A casa Schroder era, de acordo com Frampton (2008, p. 175) “elementar, econômica e funcional; não monumental e dinâmica; anticúbica em sua forma e antidecorativa em sua cor". A planta baixa do segundo pavimento era totalmente flexível, pois não existiam paredes internas e sim divisórias que podiam ser fechadas, construindo assim um amplo espaço. 


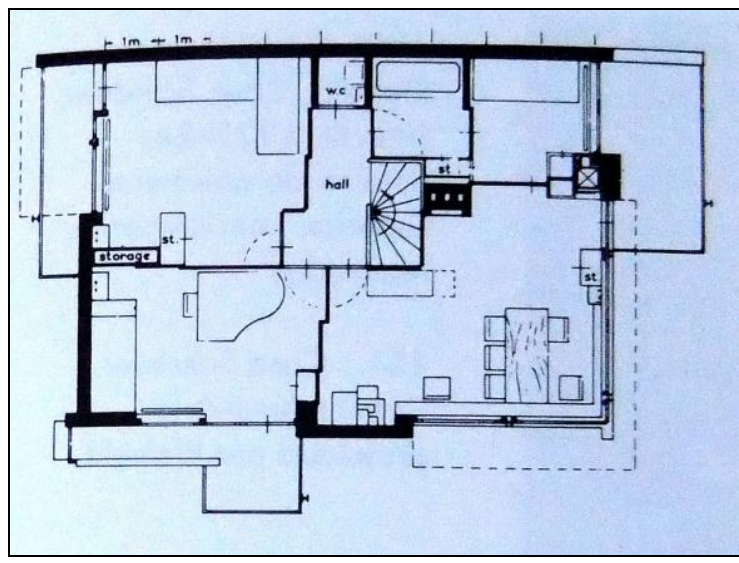

Figura 22: Planta baixa do segundo pavimento da Casa Schroder, com as divisórias. Fonte: CURTIS, p. 157

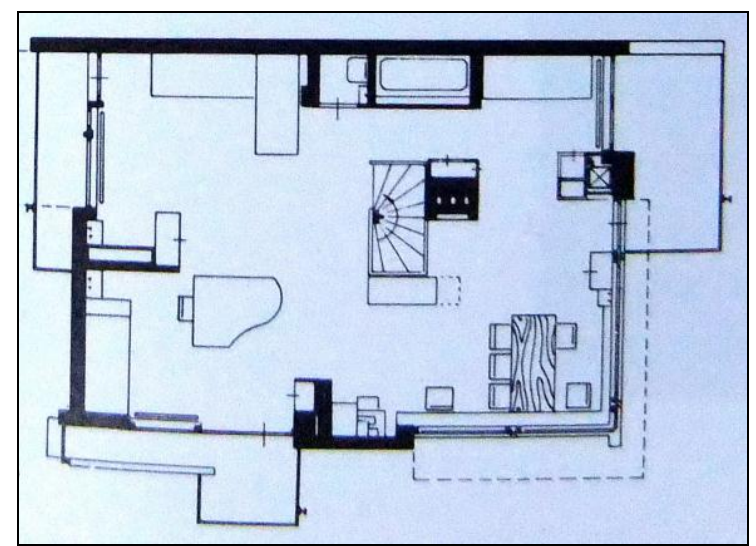

Figura 23: Planta baixa do segundo pavimento da Casa Schroder, sem as divisórias. Fonte: CURTIS, p. 157.

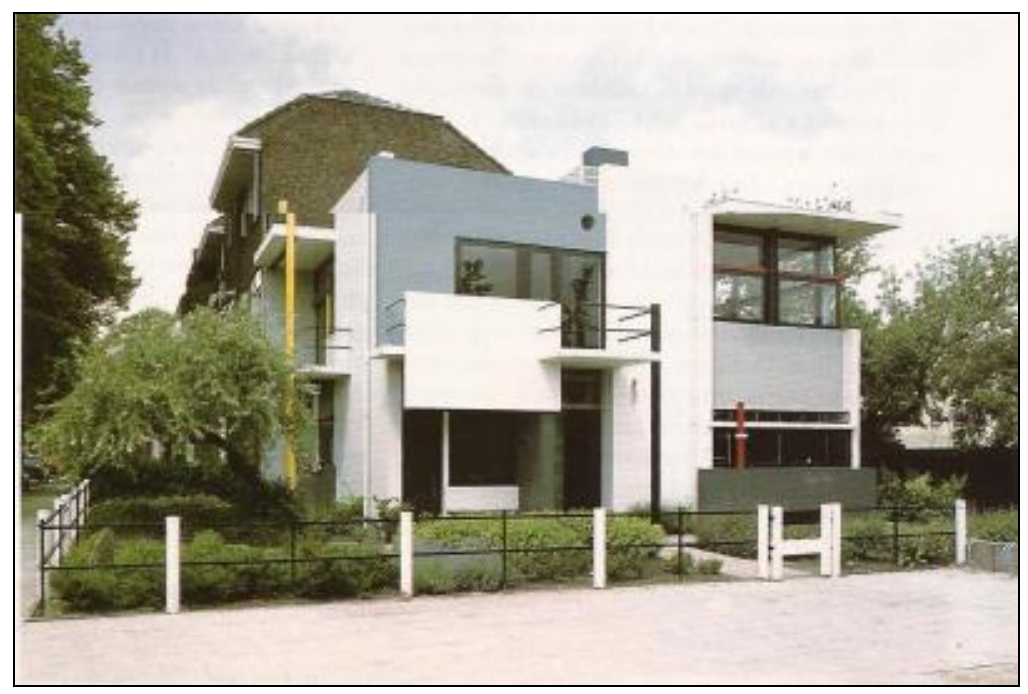

Figura 24: Fachada Casa Schroder.

Fonte: CURTIS, p. 157.

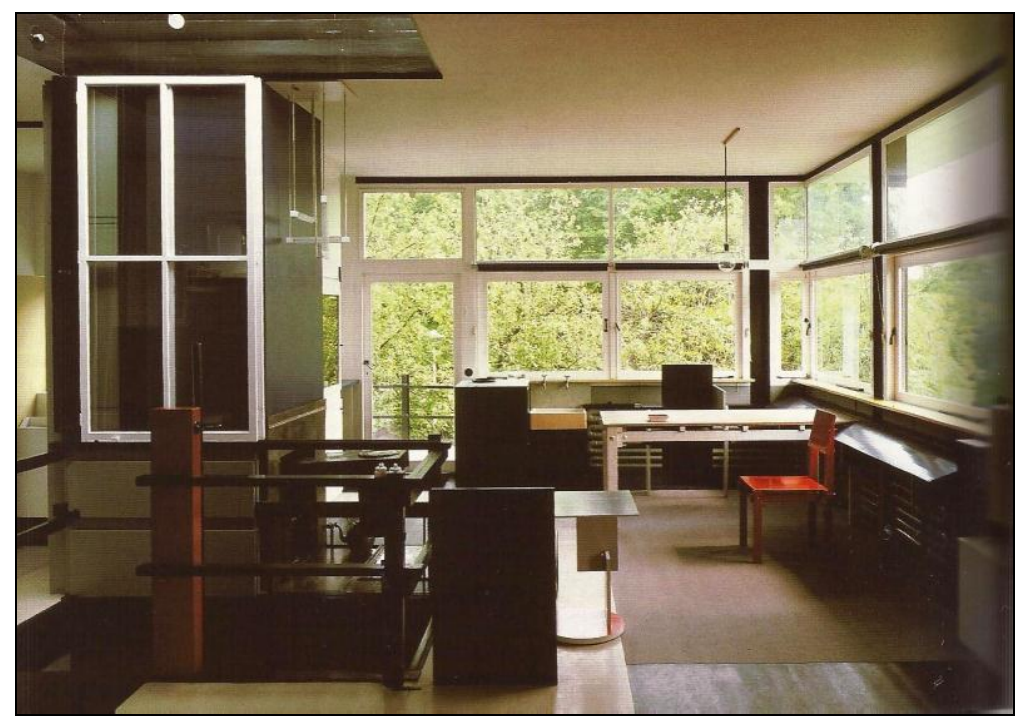

Figura 25: Interior Casa Schroder.

Fonte: CURTIS, p. 158. 
A terceira fase do momento, de 1925 a 1931 caracterizou-se pela ruptura entre Mondrian e Doesburg, pois este introduziu a linha diagonal na concepção neoplasticista. Doesburg estava desde sua aliança com Lissitztky a acreditar que a estrutura social e a tecnologia eram os principais componentes da forma, em detrimento da essência inicial do $D e$ Stijl, de harmonia universal. Também a partir dessa etapa, Doesburg se distanciou de Rietveld, que por sua vez também estava produzindo uma arte mais objetiva. Ambos os afastamentos contribuíram para dissolução do movimento em 1931.

\subsubsection{PARADIGMA FORMA X FUNÇÃO}

A era industrial que marcou o início do século $\mathrm{XX}$, trouxe para a arquitetura moderna o slogan do funcionalismo, criado por Louis Sullivan, em 1896 "a forma segue a função", (DEMPSEY, 2003). O edifício moderno, desvinculado de qualquer referência a tipologias passadas, deveria ser configurado em termos espaciais de acordo com a sua funcionalidade.

Esse paradigma teve suas origens no ramo na biologia. O naturalista francês Lamarck publicou em 1809 a teoria para a evolução dos seres vivos, de acordo com seus estudos o meio ambiente obrigava os seres vivos a mudarem seus hábitos para sobreviver, e essa mudança comportamental forçava assim a utilização ou não de alguns órgãos do corpo, culminando em um desenvolvimento ou atrofiamento de algumas partes. Como para Lamack as características adquiridas por um indivíduo eram passadas para os descendentes, isso explicava alguns órgãos bem desenvolvidos para as funções por ele desempenhadas. Assim, para Lamack a forma seguia a função. Porém, em seguida Charles Darwin, naturalista britânico, publica em 1859 um livro intitulado “A origem das espécies”, onde contesta a teoria de Lamarck ao afirmar que o ambiente exercia profunda importância nos seres vivos, que por sua vez sobreviviam de acordo com a seleção natural. Com isso, Darwin desenvolve a teoria atual da evolução das espécies. (DIOGO MEYER, CHARBEL NINO EL-HANI, 2005).

O movimento moderno então, se utiliza do termo "a forma segue a função" na composição formal dos novos edifícios, que estavam a partir de então, vinculados aos aspectos funcionais, desprezando qualquer ornamento. Assim, a arquitetura moderna também encontrou seu declínio na mesma fonte da sua ascensão. A simplicidade na construção formal, em vista a uma arquitetura universal e econômica proposta por alguns arquitetos, gerou uma profunda redução dos elementos de composição, culminando em construções desprovidas de linguagens arquitetônicas, e ainda mais, sem estudo de composições formais (na ânsia de 
fugir de qualquer contato com modelos historicistas).

O dogma disseminado na modernidade arquitetônica teve então sua contestação, pois limita a prática da arquitetura. $\mathrm{O}$ ambiente arquitetônico não deve atender somente a uma única função, uma vez que ele é construído com o intuito de atender ao homem. Ao entrar nesse tema, chega-se ao principal sujeito da arquitetura. Os edifícios são executados pelo homem e para o homem. Para Mahfuz (1995, p. 22) "a arquitetura ordena o ambiente humano, controla e regula as relações entre o homem e seu habitat. Ao fazer isso, a arquitetura serve várias funções, além das práticas”. Logo, não é a função que determina única e exclusivamente a construção formal da arquitetura. A forma é também responsável por aproximar ou separar os espaços na arquitetura. Sendo assim, ela assume o papel de ordenação do fluxo humano dentro do edifício, comunicando entre si os diferentes espaços da edificação, (MARTINEZ, 2000).

No contexto contemporâneo a prática arquitetônica é uma síntese de fatores que visam cumprir uma função e responder a um problema inicial. Dentre esses fatores está, obviamente, o programa de necessidades, pois ele é a base para construção, porém acrescidos do lugar, do clima, da cultura, do traçado urbano, de técnicas construtivas, do conforto, culminando em uma representação arquitetônica para o problema inicial. Para Mahfuz (2009) "Mesmo não sendo o objetivo exclusivo da arquitetura, a forma é seu resultado inevitável”.

\subsection{ARQUITETURA DE MUSEUS}

A abordagem a seguir mostrará brevemente um histórico acerca da origem do museu, tanto na sua essência, como no período em que se tornou uma instituição semelhante aos dias atuais. A ênfase será dada a ruptura em termos formais e filosóficos dos museus modernistas do século XX, e a atual condição da instituição na contemporaneidade. Adotando a mesma linha que o restante desse trabalho serão vistas obras arquitetônicas de importantes figuras que inauguraram uma nova fase para o museu e que são até os dias atuais referências essenciais na elaboração projetual.

\subsubsection{ORIGEM E DESENVOLVIMENTO DOS MUSEUS}

Não se sabe exatamente quando o homem surgiu na terra. Segundo Mota e Braick (2002) as primeiras espécies de hominídeos (todas as espécies de primatas) surgiram por volta de 4 milhões anos na África. O primeiro hominídeo do gênero homo foi o Homo habilis, que 
viveu por volta de 2,4 milhões a 1,5 milhões de anos atrás. O Homo habilis se diferenciou dos outros animais quando começou a produzir armas rudimentares, fabricadas com pau e pedra. A partir de então, ele pode se defender dos inimigos e caçar com maior facilidade seu próprio alimento. Esse é o primeiro período da pré-história, denominado período paleolítico, onde o Homo habilis começou a utilizar utensílios da natureza.

A essência do museu tem então sua origem no período paleolítico, quando os hominídeos sentem a necessidade de colecionar. O homem primitivo, segundo Ribeiro (1993, p. 149) "já no paleolítico juntava conchas, pedras e ossos de animais com a crença numa vida do além". Com o decorrer da história, em aproximadamente 4.500 a.C. a 539 a.C., o homem desenvolve a escrita, na região da Mesopotâmia, atual Iraque. A partir de então, grandes civilizações começam a se desenvolver, dentre elas, a civilização Egípcia, por volta de 3.000 anos a. C, (STRICKLAND, 2003). Para Ribeiro (1993) é no Egito que se encontram os primeiros objetos de grande qualidade, que já eram colecionados e guardados pelo homem. De acordo com Rangel (2008), durante a dinastia dos Ptolomeus, surgiu em Alexandria, no século III a.C, um complexo de edifícios, compostos por uma biblioteca, a qual possuía escritos de Alexandre, o grande, além de um observatório, jardim botânico e zoológico. Os edifícios abrigavam uma série de coleções, semelhante ao conceito de Universidade que a sociedade tem atualmente.

Na Grécia, os objetos colecionados eram guardados nos templos e já podiam ser visitados. É na cultura grega que surge o termo museu, denominado Museion, para os templos dedicados as Musas, filhas de Mnemósine e Zeus, os quais representavam respectivamente deuses da memória e o poder. (RANGEL, 2008).

Após Grécia, com a civilização romana surge um novo sentido para as coleções, caracterizado pelo gosto em colecionar e expor os troféus das suas vitórias. É notável a contribuição dos romanos em várias áreas do conhecimento. Eles foram os primeiros a se preocuparem com a conservação de suas obras de arte. Vitruvio há aproximadamente 2.000 anos escreveu orientações sobre entrada de luz solar nas pinacotecas romanas. (RIBEIRO, 1993).

Durante o período da Idade Média, entre o período romano e a Renascença, os objetos preciosos colecionados pertenciam a Igreja, maior símbolo do poder da época. Entretanto, grandes tesouros artísticos eram também guardados pelas famílias nobres da Europa. Para 
Ribeiro (1993) o sentido do museu que temos hoje em dia, surge na segunda metade do século XVI, com as coleções dos Médicis. Os Médicis foram uma família burguesa italiana, extremamente rica, que governaram Florença por volta de 1.400 a 1.700 d. C. A família teve importantes representantes, tanto na nobreza, quanto no poder religioso. Possuíam uma enorme riqueza, e uma vasta coleção de objetos de valor guardados nos seus palácios, e organizados em coleções privadas. (RIBEIRO, 1993). Porém, após a Revolução Francesa, em 1789, os nobres têm seus bens confiscados e a partir dessa data se originam os verdadeiros museus. Com a revolução, as coleções deixam de ser privadas e passam gradativamente, a se abrir ao público, de fato com uma série de restrições. Com o decorrer de três séculos seguintes após Revolução Francesa, surgiram inúmeras instituições museais.

Os primeiros museus de arte destinados ao público surgiram efetivamente no século XVII, como o British Museum em 1753, o Museu Pio Clementino em Roma em 1771 e o Museu do Louvre, em 1793 (Figura 26). O Louvre foi inicialmente construído em 1190 pelo rei Phillipe August, com o objetivo de ser uma fortaleza de proteção para Paris. Porém, em 1546 a construção medieval é demolida por Francisco I, então rei da França, para se construir o palácio. Ao longo de cinco séculos, importantes arquitetos participaram de diferentes reformas do Louvre. A última, em 1989 teve uma pirâmide de vidro projetada no meio do pátio central, pelo arquiteto I. M. Pei.

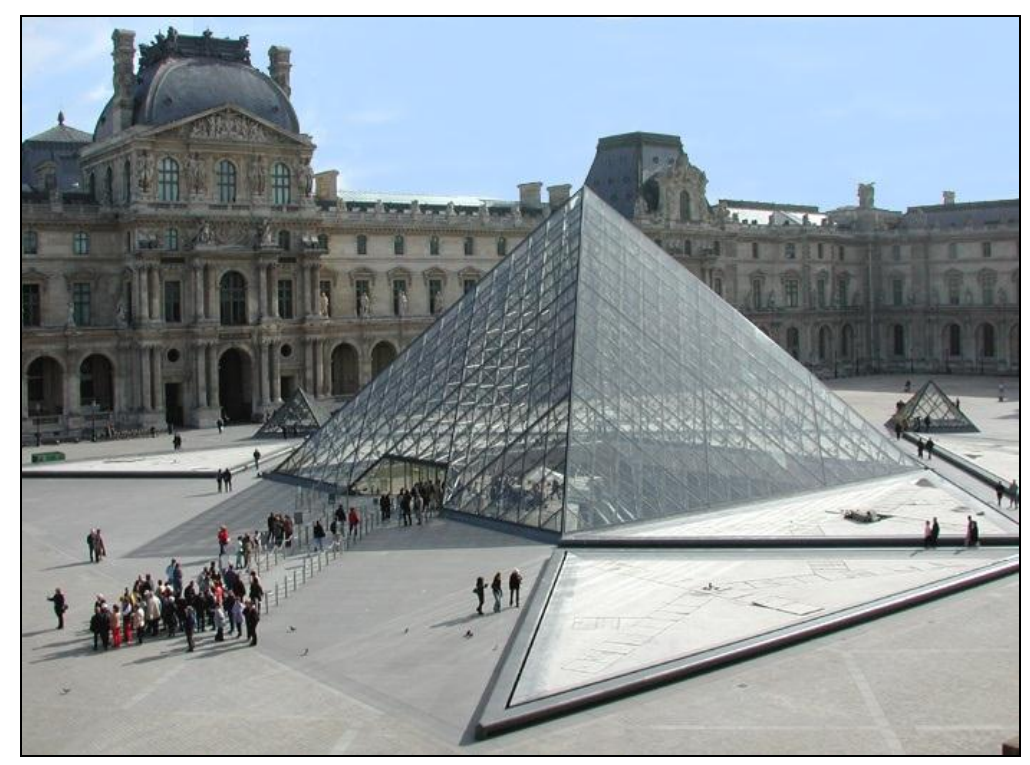

Figura 26. Museu do Louvre em Paris. onte: Google Imagens. Disponível em http://www.insecula.com/musee/photo_ME0000037737.html. Acesso em: 04 ago. 2011, 21:01. 


\subsubsection{MUSEU NA MODERNIDADE}

No início do século XX, como já citado neste trabalho, ocorre uma transformação na estética de todas as artes sem precedentes na história. Os museus também acompanham essa transição para a modernidade. De acordo com Montaner (2003) o museu a partir do século XX adota um novo sentido, uma vez que a sua filosofia já não respondia aos anseios do homem moderno.

As vanguardas do início do movimento moderno condenavam os museus, por acreditarem que eles não poderiam acrescentar nada de moderno à sociedade. Em especial o Futurismo, movimento que surge na Itália nos primeiros anos do século XX, cuja figura principal era Filippo Marinetti. Em 1909 Marinetti escreve o Manifesto futurista, onde se opõe a qualquer manifestação de arte, baseada em tradições históricas. Logo, os museus tornaram-se alvos a serem eliminados pelos futuristas. Segundo Banham (1975) Marinetti acreditava que os museus deveriam ser queimados, pois representavam cemitérios para a arte moderna.

Entretanto, essa museofobia das vanguardas, termo utilizado para Montaner para designar as críticas aos museus, foi uma espécie de ponto de partida para a transformação da instituição. Porém, a mudança demorou a acontecer, e só ocorreu, de fato, com a criação do Museu de Arquitetura Moderna de Nova York, em 1939. O MoMA foi o primeiro museu de arte moderna construído com os conceitos da arquitetura moderna, e também o primeiro museu vertical. Foi grande precursor do programa do museu contemporâneo, pois abriu espaço para a fotografia, o cinema e o desenho industrial. A partir de então, quase no fim da primeira metade do século XX, a arquitetura dos museus adquiri valor de obra artística a ser visitada também. Surgem então, notáveis contribuições arquitetônicas de arquitetos envolvidos com o movimento moderno.

Frank Loyd Wright foi uma das grandes mentes que inovaram a arquitetura e fizeram das suas obras importantes expressões do novo período estético. De origem americana e discípulo de Sullivan, Wright foi um dos primeiros arquitetos a rejeitar o ecletismo vigente e construir uma arquitetura orgânica. De acordo com Frampton (2008) o arquiteto americano desenvolveu a partir dos anos 1929 uma arquitetura de ficção científica, a exemplo do Museu Gugenheim de Nova Iorque, em 1943 (Figura 27). Segundo Montaner (2003), construído como um organismo extraordinário, o Gugenheim inovou não só na arquitetura fantástica, como no percurso interno do museu, visto e vivenciado como uma forma contínua de 
movimento. Wright abriu espaço para a mudança da forma fechada, estática e simétrica do museu, para uma forma dinâmica.

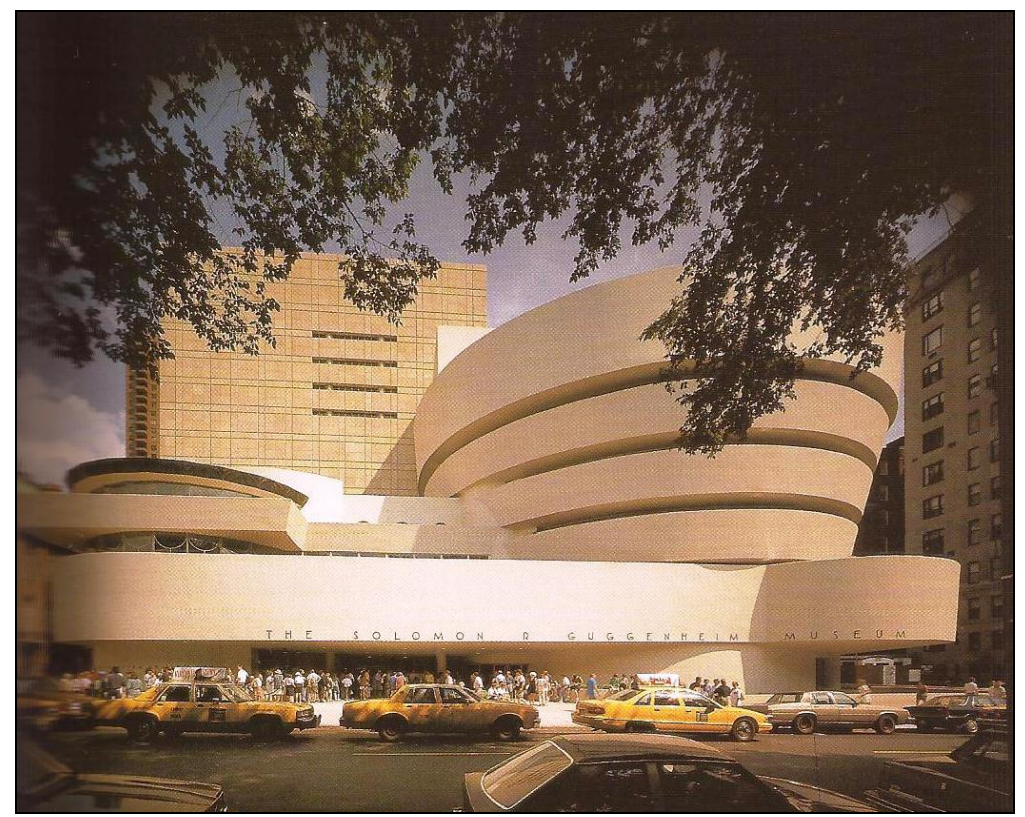

Figura 27. Museu Guggenheim de Nova York. Fonte: STRICKLAND, p. 229. Acesso em: 04 ago. 2011, 21:01

Em paralelo a idéia de arquitetura fenomenal de Wright, evolui e se modifica também no século XX a idéia primitiva de museu, como câmara de maravilhas. Segundo Montaner (2003, p. 28) "O ritual de acesso ao museu comporta a rememoração da experiência primordial e do significado inicial: uma caixa que é franqueada para que, sob um olhar atento, vá se revelando um saber escondido até aquele momento".

A modernidade arquitetônica se utiliza da idéia da caixa, porém com grandes mudanças formais. Nesse contexto, insere-se Le Corbusier, com seu modelo abstrato de museu retilíneo de crescimento ilimitado, em 1939 (Figura 28). Por meio desse protótipo, Le Corbusier explora o funcionalismo e neutralidade. Partindo então dessa concepção, ele adapta o modelo para utilizá-lo no Museu de Arte Ocidental, na cidade de Tóquio, no Japão (Figura 29). O museu possui pilotis que suscitam a idéia de um museu que se estende ao longo de um centro, (MONTANER, 2003). 


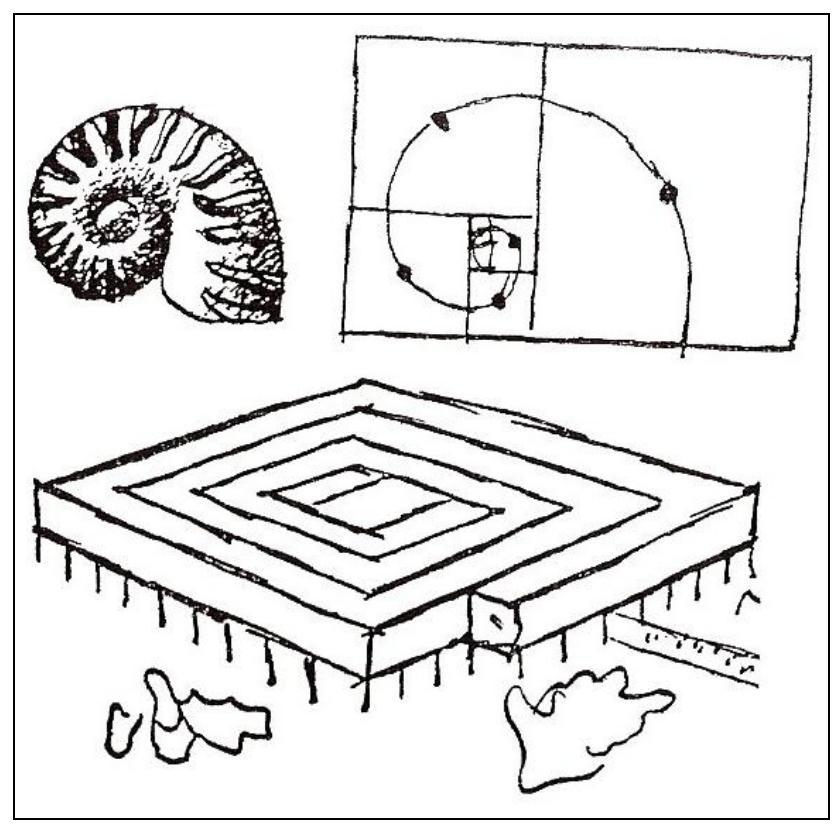

Figura 28. Modelo de Le Corbusier para museu de crescimento ilimitado.

Fonte: MONTANTER, p. 30.

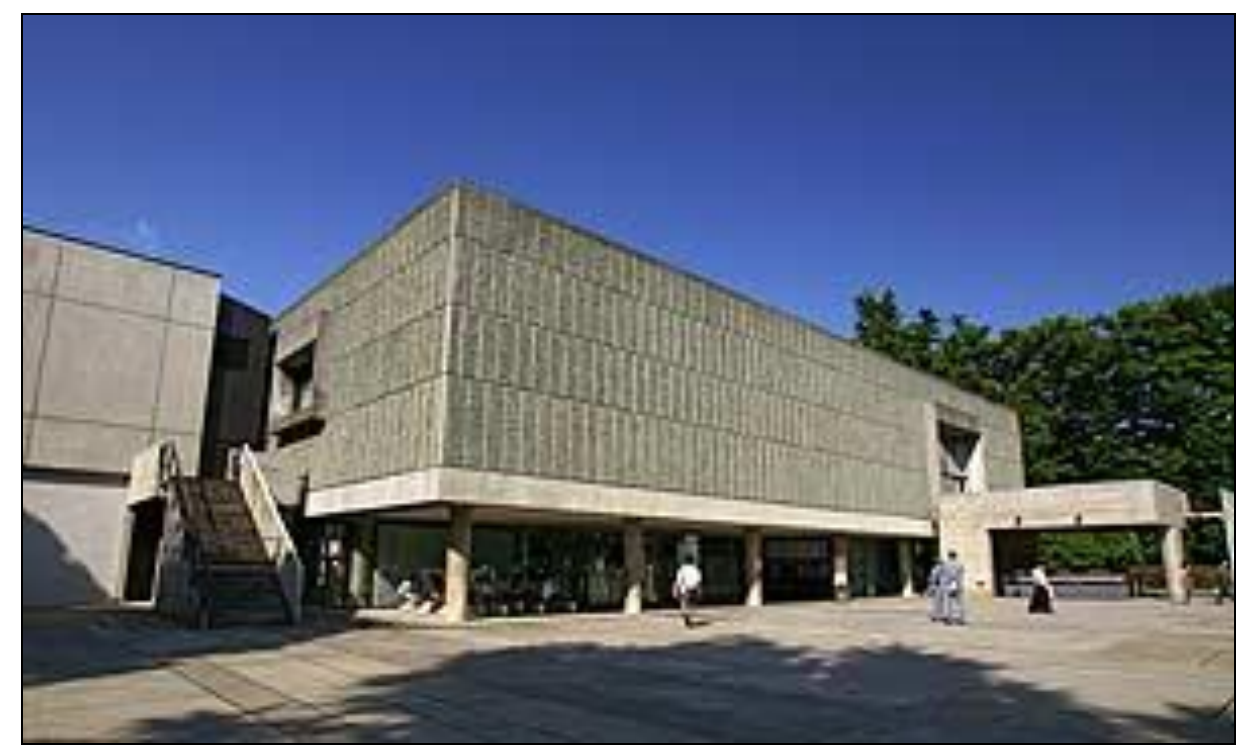

Figura 29. Museu de Arte Ocidental, Parque Ueno, Tóquio. Fonte: MONTANTER, p. 32.

Outra personalidade de destaque na transformação dos museus foi o arquiteto alemão Mies Van der Rohe, contemporâneo de Le Corbusier, que junto com ele e Frank Loyd Wright mudou a concepção do espaço museal, tanto no partido geral, quanto na compartimentação interna. Para Mies a planta do museu deveria ser flexível e acessível em um espaço moderno e universal, iluminado pela luz natural. Assim ele cria o museu de planta livre em 1942, na 
mesma idéia de composição que utilizou para o Pavilhão da feira Universal de Barcelona, em 1929. Do mesmo modo que o modelo de Le Corbusier, o museu de planta livre de Mies foi sendo adaptado, como na Neue Nationalgalerie, em Berlim, construída em 1968 (Figura 30). (MONTANER, 2003).

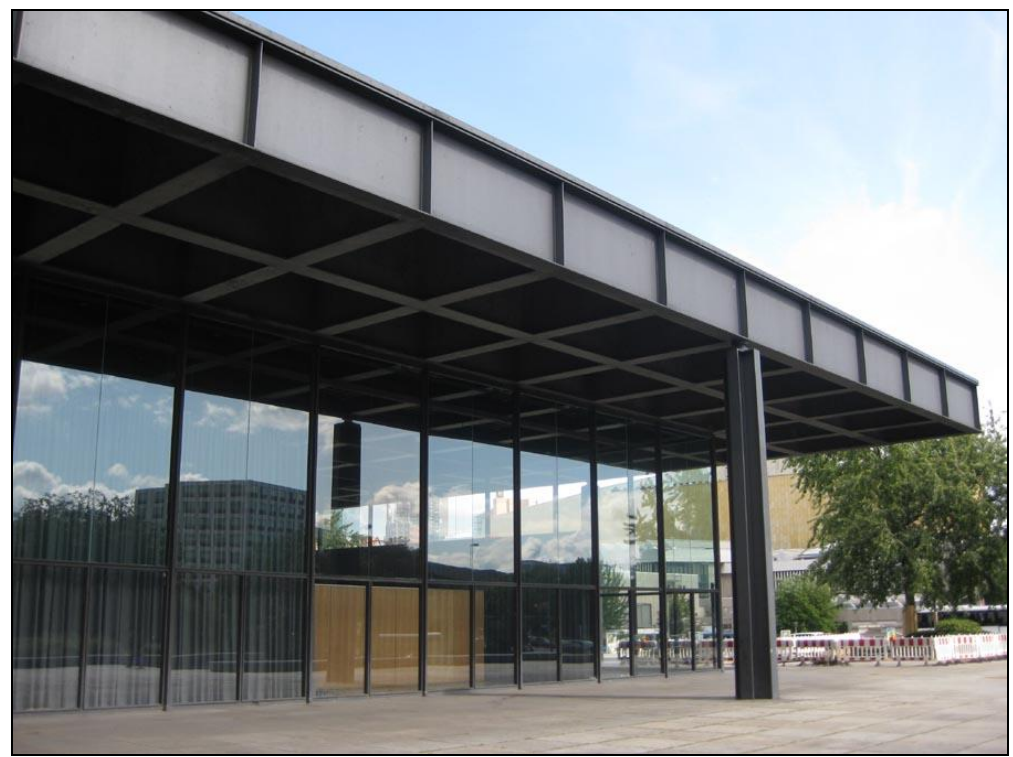

Figura 30. Neue Nationalgalerie, Berlim. Fonte: Google Imagens. Disponível em http://www.e-architect.co.uk/images/jpgs/berlin/neue_national_galerie_aw050909_7.jpg Acesso em: 07 ago. 2011, 23:04.

\subsubsection{MUSEUS MODERNOS BRASILEIROS}

A partir da década de 50, o Brasil teve uma grande participação na arquitetura de museus. De acordo com Montaner (2003) é possível visualizar as instituições do período a partir de dois grandes modelos. O primeiro estava relacionado às formas curvas e escultóricas que o arquiteto Oscar Nieymeyer vinha desenvolvendo na capital do Brasil. O segundo seguia a linha de composição utilizada pelo arquiteto Vilanova Artigas para a arquitetura pública, baseada em grandes praças cobertas, como a Faculdade de Arquitetura e Urbanismo de São Paulo, construída em 1961 e inspirada nos grandes pavilhões de Mies Van de Rohe.

Assim, o Brasil segue com o surgimento de diferentes museus que exploravam novas composições formais e novas museografias. Como exemplo, inserido dentro da tipologia de planta livre preconizada por Mies Van der Rohe está o Museu de Arte Moderna do Rio de Janeiro (Figura 31 e 32) projetado pelo arquiteto carioca Affonso Eduardo Reidy em 1948. É possível visualizar no MAM, características do Estilo Internacional, como a ênfase aos 
elementos técnicos, através circulação interna realizada pela escada helicoidal. E influências brasileiras, como os pilares inclinados de Niemeyer, e o espaço público integrado com o entorno de Vilanova Artigas, no caso o jardim de Burle Marx.

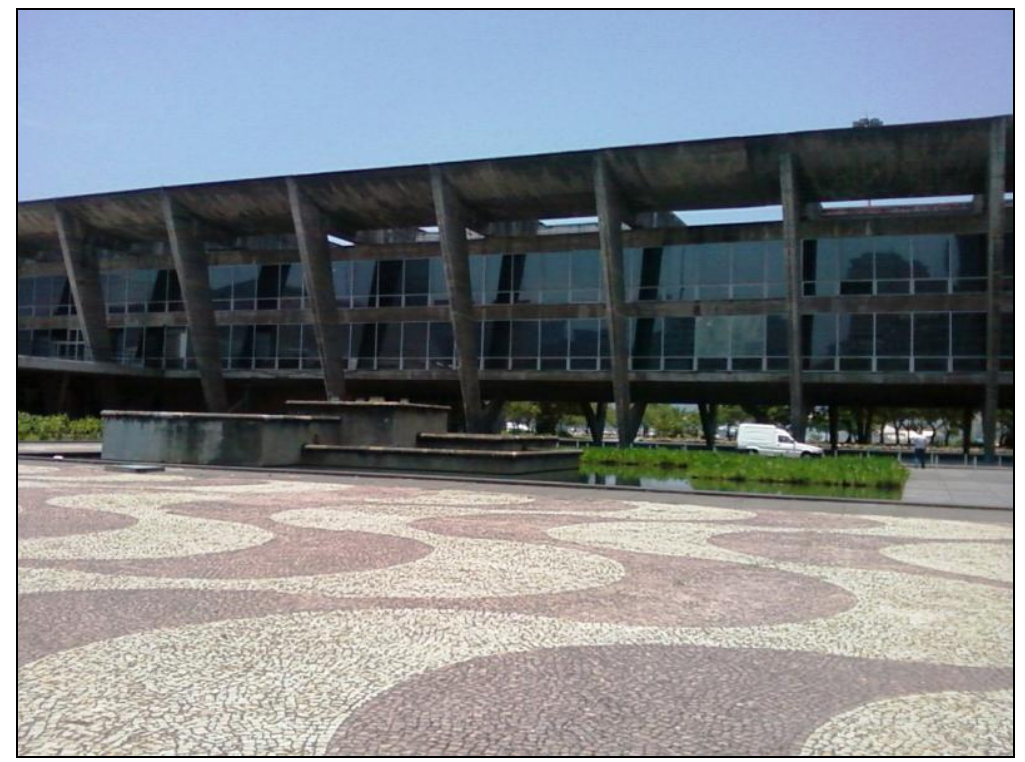

Figura 31. Museu de Arte Moderna do Rio de Janeiro. Autor da foto: Luciana Florenzano, 2010.

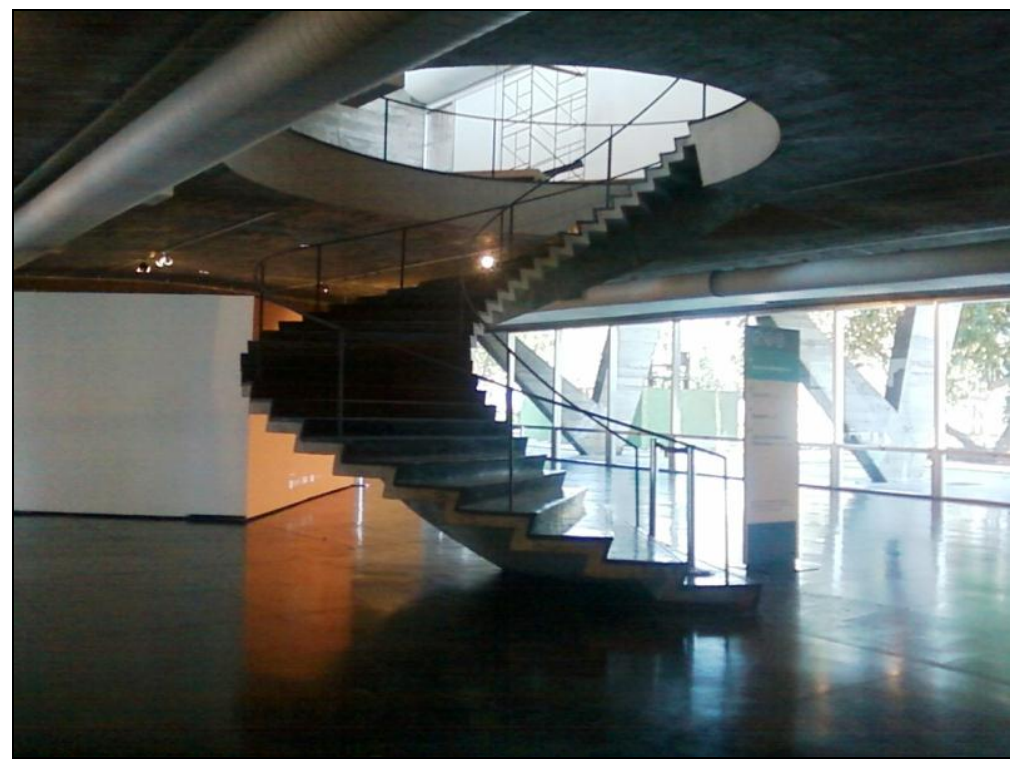

Figura 32. Museu de Arte Moderna do Rio de Janeiro. Autor da foto: Luciana Florenzano, 2010.

Em relação aos museus construídos no Brasil a partir dos anos 50, é notável a contribuição da arquiteta de origem italiana, naturalizada no Brasil, Lina Bo Bardi. Em especial o seu projeto para o Museu de Arte de São Paulo, construído em 1957. No MASP 
racionalismo e abstração aparentam serem os principais objetivos de Lina (Figura 33). A arquitetura do museu é caracterizada pela ausência de hierarquia nas fachadas, por meio de um volume suspenso por pilotis marcando uma grande praça coberta. O MASP inovou não só composição arquitetônica, mais no espaço expositivo. Lina projetou uma museografia diferente e impactante para o museu, sem a exposição dos quadros nas paredes. As obras do MASP eram expostas em blocos de cristais, apoiados em cubos de concreto. O espaço do museu é totalmente livre para circulação entre as obras de arte, que por sua vez estão como que flutuando dentro do espaço.

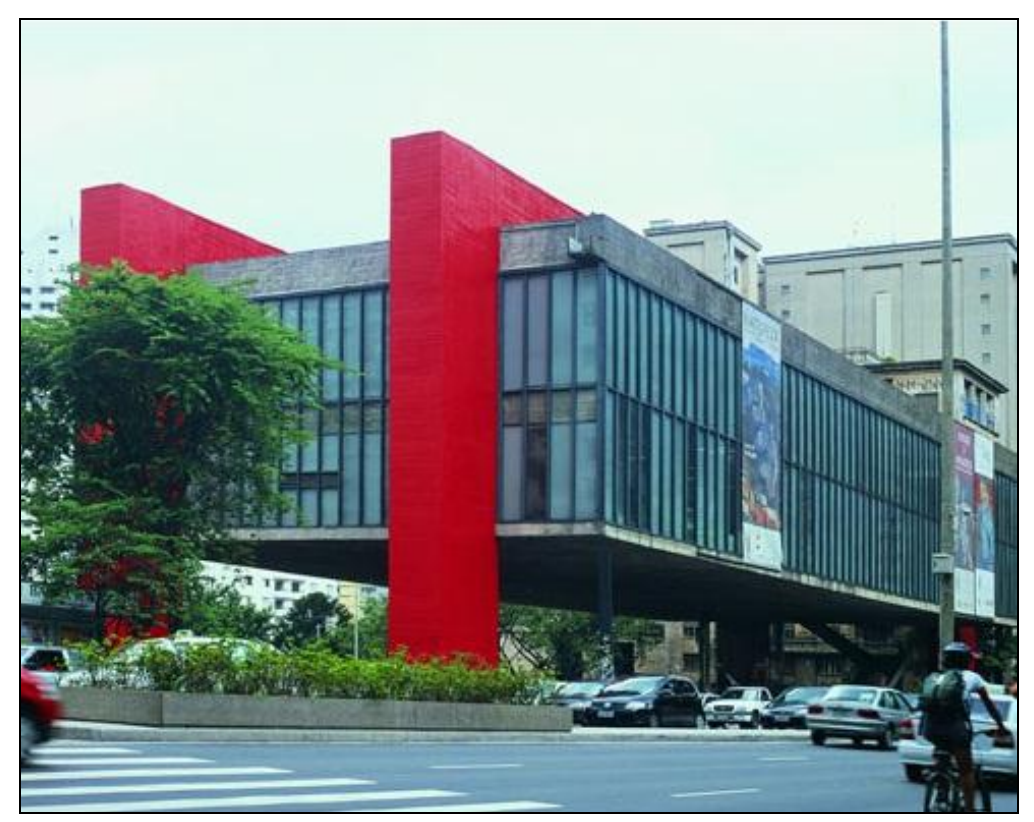

Figura 33. Museu de Arte de São Paulo. (MASP)

Fonte: Google Imagens. Disponível em http://masp.art.br/masp2010/sobre_masp_galeria.php. Acesso em: 03 ago. 2011, 22:56.

\subsubsection{MUSEU CONTEMPORÂNEO}

Os museus contemporâneos vêm desde a década de 70 modificando sua arquitetura e suas funções. Na atualidade, surgiram vários expoentes de uma nova arquitetura dos espaços museais, como a arquitetura minimalista do arquiteto japonês Tadao Ando e a arquitetura como contêiner, uma espécie de evolução da caixa, vista no Centro Pompidou em Paris, projetado em 1977, pelos arquitetos Renzo Piano e Richard Rogers (Figura 34). A arquitetura contemporânea de Piano e Rogers traz como referência, as fábricas e as novas possibilidades construtivas, com ênfase nas escadas rolantes e elevadores. 
Os museus contemporâneos passaram a ter importância econômica, além da social, pois alimentam o setor turístico das cidades. Como exemplo pode ser citado o Guggnheim de Bilbão, na Espanha, um museu que trouxe muitos turistas para uma cidade, até então esquecida como Bilbao (Figura 34).

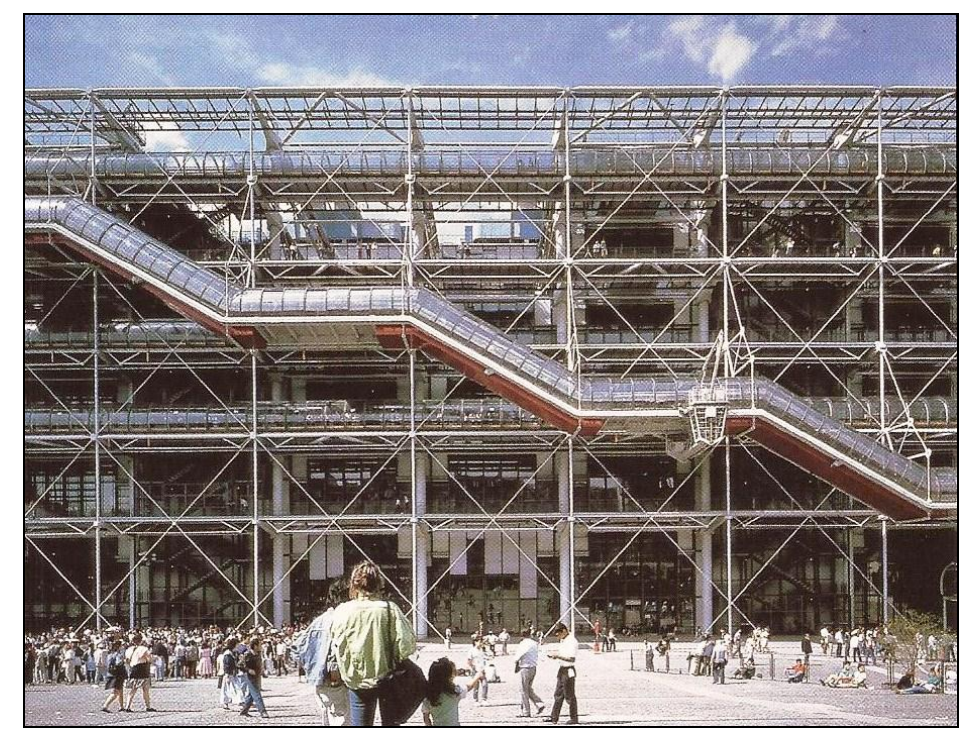

Figura 34. Centro Pompidou.

Fonte: STRICKLAND, p. 148.

No Brasil, também há vários exemplos que marcam a nova fase vivenciada pelo museu contemporâneo. Principalmente com o objetivo de atrair turistas, a arquitetura de alguns museus se tornou obra de arte. Como na Fundação Iberê Camargo, em Porto Alegre, projetada pelo arquiteto português Álvaro Siza (Figura 35). E no Museu de Arte Contemporânea de Niterói, construído em 1996 (Figura 36), onde mais uma vez Niemeyer explorou o concreto armado e o utilizou para realizar uma arquitetura totalmente desvinculada do ângulo reto.

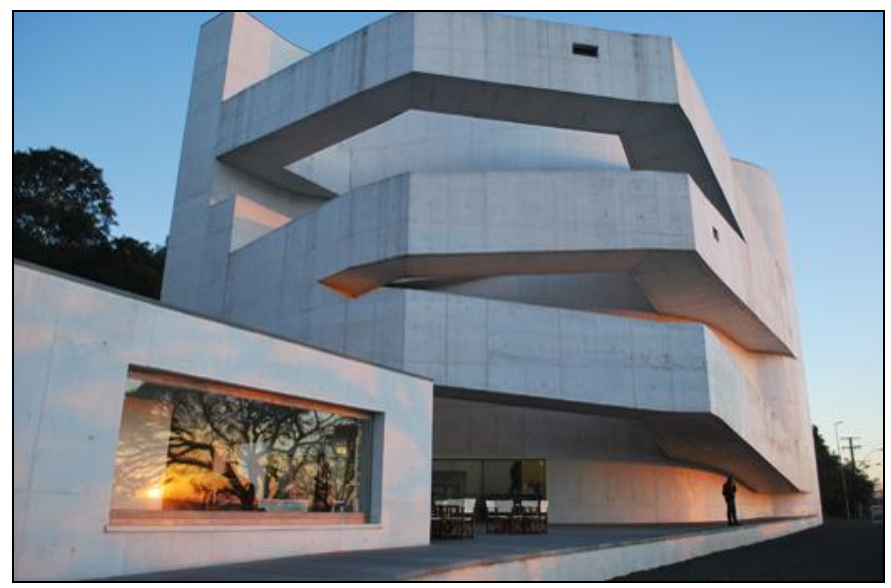

Figura 35. Fundação Iberê Camargo em Porto Alegre. Fonte: Google Imagens. Disponível em http://www.iberecamargo.org.br/a-fundacao/default.aspx. Acesso em: 04 ago. 2011, 21:35. 


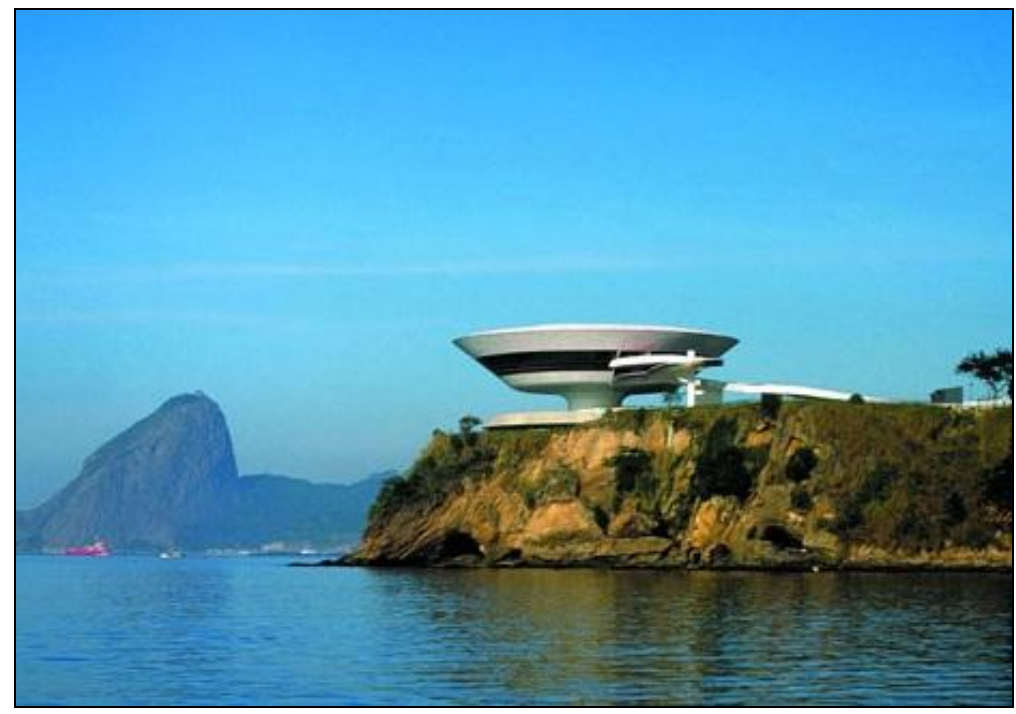

Figura 36. Museu de Arte Contemporânea em Niterói. (MAC) Fonte: Google Imagens. Disponível em http://www.niemeyer.org.br. Acesso em: 03 ago. 2011, 23:14.

Atualmente, os museus abrigam uma série de funções, além da contemplação visual das obras. Incorporam outras atividades de lazer e convivência, com espaços destinados a amostras de filmes, restaurantes, lanchonetes, e espaços de consumo. Desse modo, aproximam arte do comércio. O museu contemporâneo é dessa forma um organismo vivo em contínua transformação no cotidiano da sociedade.

\subsection{CONSERVAÇÃO}

O processo cultural desenvolvido por cada sociedade reflete em diversos elementos a compor o patrimônio natural. Esses bens culturais documentam a cultura material da sociedade, pois eles são a matéria concreta da existência de outros povos e dos recursos naturais e riquezas de cada nação.

O museu é o local onde se guardam os bens culturais, e mais do que isso, além da exposição ao público, devem desenvolver continuas pesquisas e promover adequada conservação do acervo. Por conservação entende-se (SECRETARIA DE ESTADO DA CULTURA, 2008, p. 13) “conjunto de técnicas e procedimentos destinados a proteger um objeto contra fatores de diferentes naturezas - físicos, químicos, biológicos e humanos - que possam agir sobre ele, sozinhos ou conjuntamente, ameaçando a até destruindo sua integridade". 
O estado em que se encontra cada bem natural ou obra de arte relaciona-se aos aspectos dos seus materiais constituintes e a que condições eles foram mantidos. Logo, se as peças estão bem conservadas, devem somente ser guardadas e expostas em condições adequadas de clima, e iluminação e proteção.

Assim, para o correto funcionamento do museu devem ser previstas medidas de segurança, tanto contra incêndio, quanto contra furtos, controle do clima, da iluminação solar e artificial no interior do edifício. O programa de um museu deve estar adequado às funções determinadas para ele, com uma circulação para o público e outra para funcionários. Outro fator determinante para o museu é sua reserva técnica, pois a mesma deve ser projetada em um local seguro, de preferência no térreo da edificação e em um ambiente sem umidade e incidência da radiação solar.

Será pertinente para o trabalho, o entendimento da conservação dos minerais e mapas, pois constituem os materiais do acervo do Museu de História Geológica da Amazônia.

\subsubsection{PAPEL}

O papel industrial é criado a partir da celulose da madeira em associação a outros componentes, como açúcar, colas, amidos e lignina. O processo de produção do papel já o danifica, pois são adicionados produtos químicos que visam branquear o papel e que assim, comprometem a estrutura celulósica do material.

Em um adequado projeto, devem ser previstos locais bem arejados e livres de incidência solar para a exposição dos mapas, com uma temperatura entre 18 e $22^{\circ} \mathrm{C}$ e taxa de umidade relativa do ar, entre 45 e $60 \%$. Outro fator importante para a conservação dos mapas, que deve que utilizado, é a colocação de molduras no mesmo, geralmente em aço ou alumínio, pois assim evita-se o dano causado pelo manuseio com as mãos, que podem estar sujas ou molhadas e o contato com possíveis insetos. Por fim, nunca utilizar fitas colantes, como o durex, visto que, esse material solta substâncias que mancham por definitivo o papel.

\subsubsection{PEDRAS}

Os minerais, para Miguel e Altaba (1975, p. 7) "são os seres que ocorrem naturalmente na parte sólida da crosta terrestre e possuem composição química definida, cujas partículas elementares (íons, átomos e moléculas) são ordenadas sistematicamente”. Podem se 
apresentar em poliedros bem definidos, como os cristais, os quais são obtidos com a associação de diferentes elementos químicos presentes na formação de muitas rochas. Assim, as pedras naturais são o resultado da fragmentação das rochas. As rochas magmáticas, eruptivas (granitos, quartzos, feldspatos e micas) ou ígneas surgiram na Terra a partir do resfriamento da crosta terrestre, formadas em sua maioria por compostos de silício, oxigênio e alumínio. Logo, as pedras naturais são muito resistentes. (SECRETARIA DE CULTURA DO ESTADO, 1998).

O processo de degradação das pedras é lento e continuo, por ação da água ou da umidade, da temperatura, da poluição, dos ventos, de microrganismos, caracterizando assim, o envelhecimento normal da pedra, onde o material perde umidade interna e resseca, oxida e endurece. Com o tempo aparecem fissuras que levam a sua ruptura. Variações bruscas de temperatura trazem danos às pedras, pois causam dilatação e retração.

A conservação a se ter com os minerais é simples, não precisando de grande trabalho quanto a sua exposição ou reserva técnica. Os cuidados são básicos e inclui além do correto acondicionamento em locais protegidos de umidades excessivas e mudanças bruscas de temperatura, uma limpeza regular com uma escova de cerdas macias para eliminar a poeira incidente. E acima de tudo, as peças não devem estar em contato direto com a radiação solar, pois algumas pedras, a exemplo da ametista, perdem o brilho após intensa exposição ao sol. 


\section{ABORDAGEM METODOLÓGICA}

Com o objetivo de elaborar uma proposta arquitetônica para o Museu de História Geológica da Amazônia, o presente trabalho foi estruturado a partir de três etapas: revisão bibliográfica, pesquisa de campo e estudos projetuais, culminando no projeto arquitetônico.

A primeira etapa, que consiste na revisão bibliográfica, teve início com uma pesquisa acerca dos princípios fundamentais da arquitetura, visando a compreensão de como ocorre, de fato, a composição formal, desde a concepção da forma abstrata até a materialização da mesma no espaço. E para tal, o estudo se fundamentou na leitura de livros sobre os conceitos de composição e a aplicação dos mesmos da arquitetura. Em um segundo momento dessa revisão, a pesquisa foi conduzida por novas leituras, dessa vez acerca da prática arquitetônica visualizada a partir do movimento moderno.

A etapa seguinte se fundamentou em uma pesquisa direcionada a arquitetura de museus. Dessa forma, o trabalho foi conduzido de modo a englobar os conceitos referentes ao museu e o significado da instituição museal através de uma revisão bibliográfica sobre o tema.

Em seguida, iniciou-se a segunda etapa, referente à pesquisa de campo, direcionada aos museus na cidade de Belém. Tal pesquisa contemplou visitas a onze instituições e coletou informações sobre a arquitetura de museus na cidade, por meio da análise geral de cada edifício, visualizando os ambientes, com suas aberturas, acessos e funções. Em última análise, porém mais profunda, a pesquisa foi direcionada ao Museu de Geociências da Universidade Federal do Pará, reunindo informações sobre sua história e seu acervo, através de entrevistas com os usuários do museu, e um levantamento cadastral da coleção.

Concluído o embasamento teórico e o levantamento de informações, a etapa seguinte consistiu na elaboração da proposta para o museu, iniciando com a definição do programa de necessidades, o pré-dimensionamento dos ambientes, organograma e fluxograma. Com as diretrizes e condicionantes do projeto definidas, foram feitos estudos pré-projetuais, levando em consideração a legislação do Plano Diretor Urbanístico da Cidade Universitária José da Silveira Netto e o entorno do terreno escolhido para locação do museu. Com essas condições, foram iniciados croquis a mão, objetivando aplicar os conceitos pesquisados no projeto; e em seguida o estudo foi feito utilizando o programa Google Sketchup. Simultaneamente aos 
testes volumétricos, foram feitos estudos de plantas baixas através do programa Autodesk AutoCAD.

A proposta está fundamentada de acordo com o Plano Diretor Urbanístico da UFPa, obedecendo todas as condições impostas pelo mesmo. O processo projetual ocorreu de forma a cumprir todas as condições estabelecidas pelas normas da ABNT, sendo elas a NBR 9050, a norma de acessibilidade, e a NBR 9077, norma de saídas de emergência. Tais medidas foram adotadas com o intuito de criar um espaço acessível, agradável, com boas soluções para os diversos fluxos e com um partido arquitetônico condizente com a essência do Museu de Geociências da UFPa. 


\section{ARQUITETURA DE MUSEUS NA CIDADE DE BELÉM}

Os museus são lugares de conhecimento e vivência, e exercem cada vez mais papel sócio-cultural, acabando de uma vez com a postura antiga dos museus passados, de espaços distantes do povo. Os museus contemporâneos foram sendo moldados a partir da modernidade e atualmente são instituições a serviço da comunidade, trazendo conhecimento específico através do espaço expositivo e de constantes pesquisas.

Os museus do século XIX exercem assim, uma função pedagógica, pois abrigam inúmeras atividades educativas, alcançando todas as faixas etárias. Para tal acontecimento, fazem parte uma série de profissionais, dentre eles arquitetos, museólogos, conservadores e educadores. A cada dia, o espaço expositivo do museu torna-se mais complexo, com o objetivo de atrair o público. Logo, existe um longo período de fundamentação da exposição, desde a idéia e planejamento até a montagem. O estudo da exposição contemporânea envolve uma série de fatores, como acessibilidade para qualquer tipo de portador de necessidades especiais, iluminação, conservação das obras, e segurança tanto para as peças, quanto para o público, cada vez maior.

A cidade de Belém, capital do estado do Pará, contêm um número considerável de instituições museais, e que contribuem para o estudo da museologia e para o desenvolvimento de pesquisas dentro da região norte. Grande parte dessas instituições está localizada em importantes edifícios, tanto do ponto de visto histórico, quanto arquitetônico, os quais foram adaptados através de investimentos e restaurações, para servir aos novos usos. Característica marcante na cidade, é que infelizmente, nenhuma instituição foi projetada e erguida para ser um museu.

Belém expandiu também suas galerias, e locais expositivos, contando assim com uma extensa quantidade desses espaços. No presente trabalho, serão abordadas na capital do Pará somente as instituições que ultrapassam os limites da exposição, desenvolvendo constantes pesquisas e aquisição de um acervo permanente. Dessa forma, esta pesquisa abrange onze museus, dos quais cinco são abordados mais especificamente, e que tem como objetivo, um panorama sobre a arquitetura museal em Belém. Os tópicos abordados foram quanto à história da edificação, assim como seu partido arquitetônico, os acessos, a iluminação, o programa de necessidades e o acervo, tanto o exposto, quanto o guardado na reserva técnica. 
Os museus foram divididos em quatro categorias, de acordo com o Instituto Brasileiro de Museus/Ministério da cultura (2011), por meio do Guia Brasileiro de Museus, apenas para melhor compreensão do universo das instituições em Belém. Entretanto, existem museus que não se encaixam somente em uma categoria, prevalecendo dessa forma, o acervo permanente.

Nessa pesquisa serão adotadas as seguintes categorias para o acervo:

\section{ARTES VISUAIS}

Coleções de pinturas, esculturas, gravuras, e desenhos, incluindo a produção relacionada à Arte Sacra. Nesta categoria também estão incluídas as chamadas Artes Aplicadas, ou seja, as artes que são voltadas para a produção de objetos, tais como porcelana, cristais, prataria, mobiliário, tapeçaria etc. (IBRAM, p. 19). Os museus inseridos nesta categoria na cidade de Belém são:

1.1. Museu de Arte de Belém;

1.2. Museu da UFPA ;

1.3. Museu de Arte Sacra;

1.4. Museu casa das onze janelas.

\section{HISTÓRIA}

Bens culturais que ilustram acontecimentos ou períodos da História. (IBRAM, p. 19). Os museus inseridos nessa categoria na cidade de Belém são:

2.1. Museu do Círio;

2.2. Museu do Estado do Pará .

\section{ETNOGRAFIA E ANTROPOLOGIA:}

Coleções relacionadas às diversas etnias, voltadas para o estudo antropológico e social das diferentes culturas. Ex: acervos folclóricos, artes e tradições populares, indígenas, afrobrasileiras, do homem americano, do homem do sertão etc. (IBRAM, p. 19). Os museus inseridos nessa categoria na cidade de Belém são:

3.1. Museu do Forte do presépio. 


\section{IMAGEM E SOM}

Documentos sonoros, videográficos, filmográficos e fotográficos. (IBRAM, p. 19). Os museus inseridos nessa categoria na cidade de Belém são:

4.1. Museu da Imagem e do Som

\section{CIÊNCIAS NATURAIS E HISTÓRIA NATURAL}

Bens culturais relacionados às Ciências Biológicas (Biologia, Botânica, Genética, Zoologia, Ecologia etc.), às GeoCiências (Geologia, Mineralogia etc.) e à Oceanografia. (IBRAM, p. 19). Os museus inseridos nessa categoria na cidade de Belém são:

5.1. Museu Emilio Goeldi;

5.2. Museu de Gemas;

5.3. Museu de Geociências da UFPA. 


\subsection{MUSEUS ARTES VISUAIS BELÉM}

\subsubsection{MUSEU DE ARTE DE BELÉM}

\subsubsection{HISTÓRICO}

O museu de arte de Belém está localizado no Palácio Antônio Lemos, também conhecido como Palacete Azul (Figura 37). A construção do edifício inicia-se em 1860, data registrada em uma moeda comemorativa cunhada em 14 de abril de 1860. (FUMBEL, 1996). O Palácio foi inaugurado em 15 de agosto de 1883, em comemoração aos 60 anos da adesão do estado do Pará a Independência, e foi erguido para ser a sede da Intendência Municipal. O prédio foi construído e projetado por José Coelho da Gama Abreu, conhecido como Barão de Marajó, informação também cunhada na mesma moeda. O Palacete Azul é um dos representantes mais expressivos do estilo Imperial Brasileiro na região do Norte do Brasil, erguido no auge do ciclo da borracha na Amazônia.

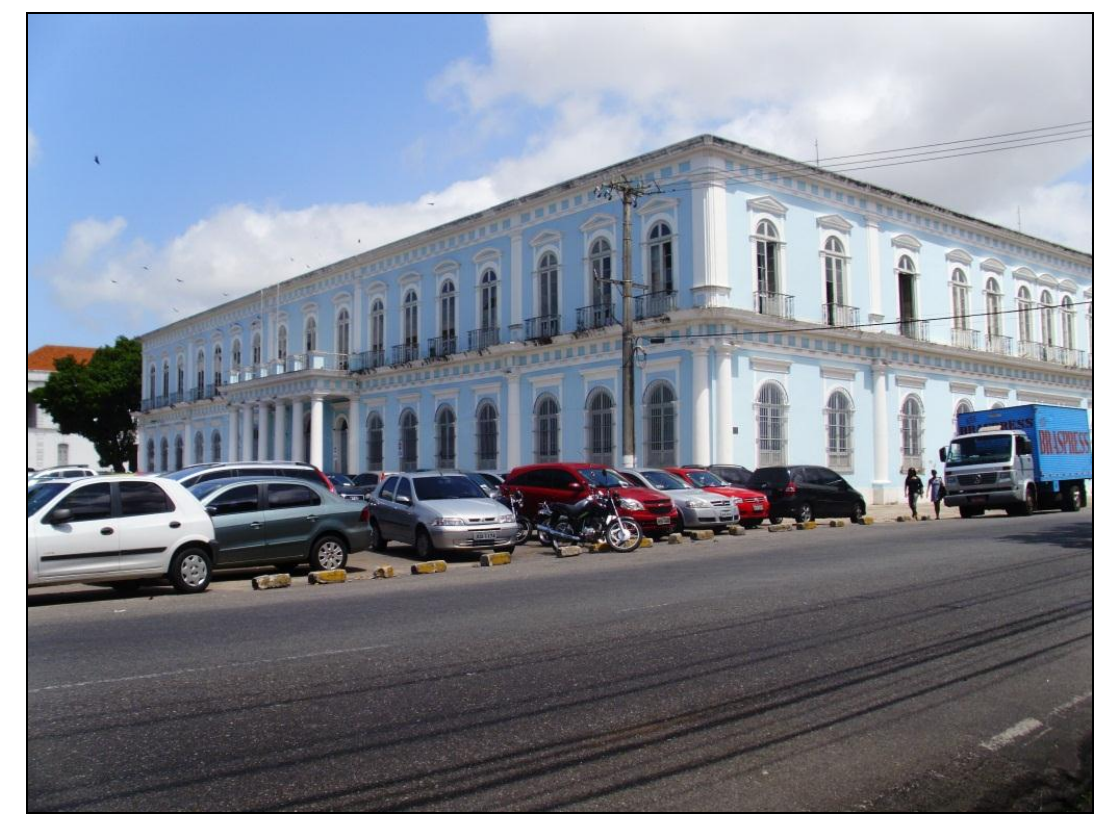

Figura 37. Museu de Arte de Belém. Autor da foto: Luciana Florenzano, 2011.

A partir da década de 80, Belém passou a ser uma cidade integrada ao cenário artístico brasileiro, com o surgimento de organizações culturais, voltadas para o desenvolvimento da cultura local. É criada então, em 1983, a Pinacoteca Municipal de Belém. E em 1986 é criado pela lei municipal, $\mathrm{n}^{\circ}$ 7.348, o Museu da Cidade de Belém, a partir da Pinacoteca. Em seguida, em 1989 é criada a Fundação Cultural do Município de Belém (FUMBEL). E no ano 
de 1994, após uma reforma, o Palácio Antônio Lemos, torna-se sede do Museu de Arte de Belém, em substituição ao Museu da Cidade de Belém. Todo o acervo do Palácio (móveis, luminárias, esculturas, e pinturas) foi incorporado ao acervo do Museu. (BRITTO, 1996). Em 1996, o MABE torna-se membro do Conselho Internacional de museus (ICOM).

Seguindo a tendência dos museus contemporâneos, o Museu de Arte de Belém possui um trabalho interdisciplinar, envolvendo diversos profissionais nas montagens das exposições, como arquitetos, arte-educadores, artistas plásticos, museólogos e restauradores. (BRITTO, 1996).

\subsubsection{PARTIDO ARQUITETÔNICO E ARQUITETURA INTERNA}

O Palácio Antônio Lemos é estilo neoclássico visto através da simetria das plantas, frontões triangulares e colunas dóricas das fachadas, com a cobertura em telha de barro cozido. O museu chama a atenção tanto pela fachada, quanto no interior através da escadaria em Mámore (Figura 38). O MABE possui $3.500 \mathrm{~m}^{2}$ e três salões para as exposições. São eles o salão verde, o rosa e o dourado, situados no pavimento superior.

O MABE tem como meta preservar, restaurar, adquirir, pesquisar e divulgar a sua coleção, e outras manifestações artísticas. Contribui para o desenvolvimento da sociedade paraense, uma vez que está em constante relação com as escolas, e instituições de pesquisa. Dessa forma, o museu possui espaços destinados a essas atividades, como salas para exposições, biblioteca, laboratório de restauro e conservação, reserva técnica, auditório, sala de fotografia e outras salas para oficinas, além do setor de funcionários, com a copa, refeitório e do gabinete do prefeito (Figura 39).

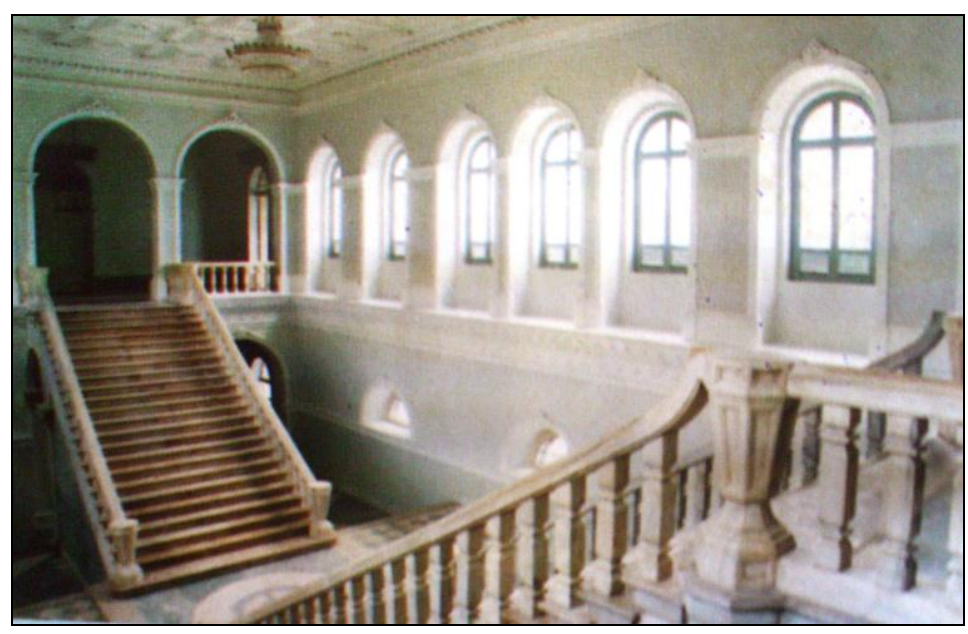

Figura 38. Escadaria em mármore do Museu de Arte de Belém. FUMBEL, 1996, p. 07. 


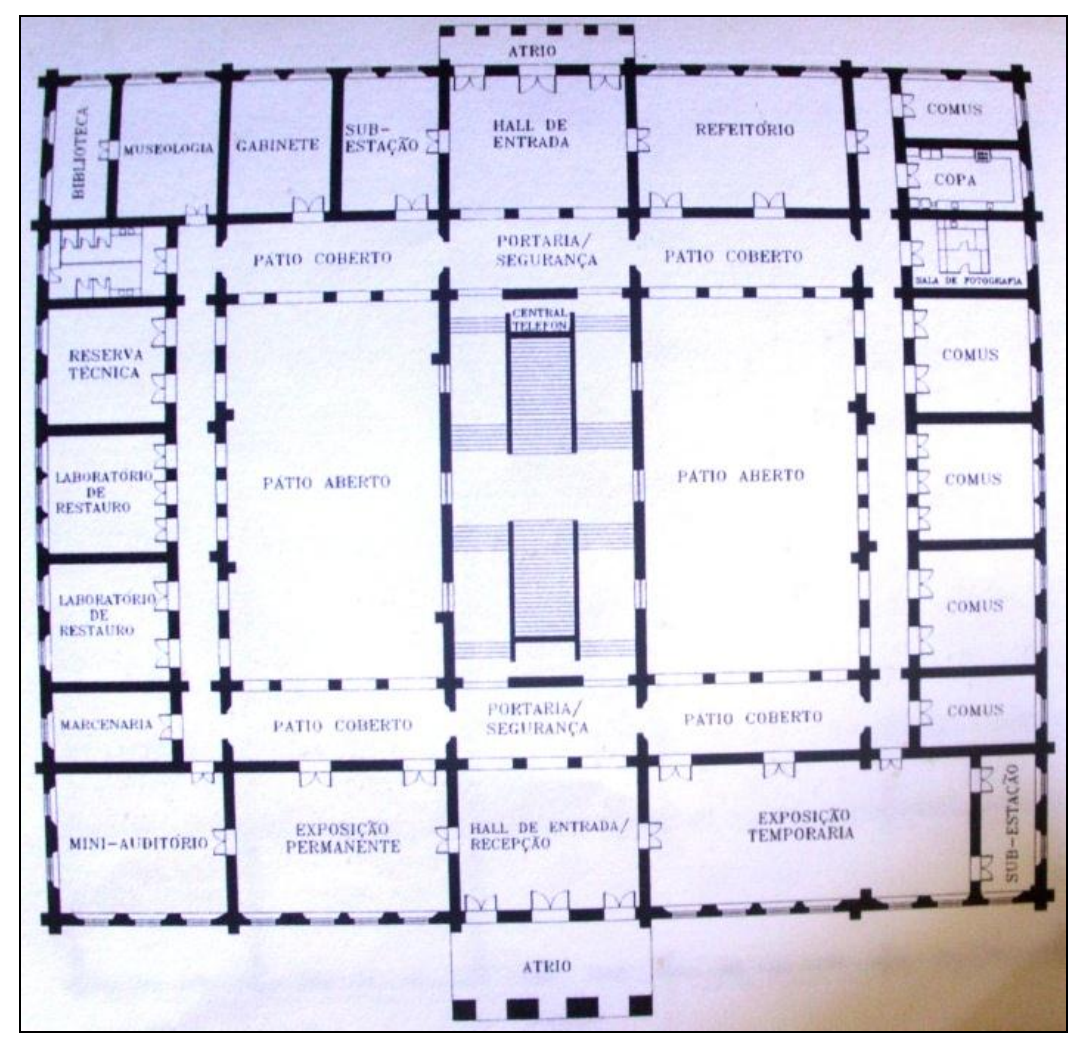

Figura 39. Planta baixa do Museu de Arte de Belém. FUMBEL, 1996, p. 05.

O museu também conta, com uma sala denominada "Museologia", onde são realizadas palestras e oficinas. E além de abrigar o museu, o Palácio também é sede do gabinete da prefeitura municipal de Belém.

\subsubsection{ACERVO}

A coleção do Museu, relacionada às artes visuais é composta por volta de 1.000 peças. Entre obras de pintura, escultura, desenhos, cerâmicas, gravuras, fotografias e o mobiliário do Palácio.

\subsubsection{MUSEU DA UNIVERSIDADE FEDERAL DO PARÁ}

\subsubsection{HISTÓRICO}

O prédio que abriga o museu da Universidade Federal do Pará foi construído no início do século, para ser a residência do governador Augusto Montenegro, e dessa forma ficou conhecido como Palacete Montenegro (Figura 40). 


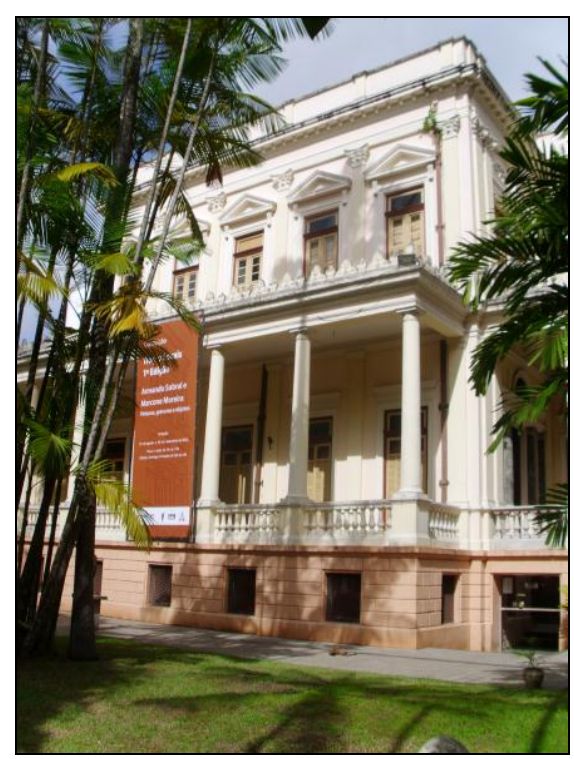

Figura 40. Fachada do Museu da Universidade Federal do Pará. Autor da Foto: Luciana Florenzano, 2011.

Na década de 60 a UFPa comprou a residência, com o objetivo de transformar o edifício em sede da reitoria. Em razão desse novo uso, o prédio passou por uma reforma, na qual, infelizmente sofreu diversas perdas, pois devido ao regime militar vigente a maioria dos detalhes decorativos foram considerados inadequados a um prédio de uso oficial.

Na década de 70 é criado o campus da UFPa, localizado no bairro do Guamá e então, em 1982 a reitoria da Universidade é transferida para o campus. Dessa forma, a residência torna-se museu, em 1985. Como não havia um acervo próprio, o MUFPA não possuía reserva técnica e nem recurso financeiro para aquisição de um acervo. A instituição sofreu um período de desgaste arquitetônico, até os anos 2000, devido à falta de investimentos. No ano de 2003, o palacete Augusto Montenegro é tombado pelo Governo do Estado do Pará e com nova direção, o museu é reformado.

\subsubsection{PARTIDO ARQUITETÔNICO E ARQUITETURA INTERNA}

O governador Augusto Montenegro encomendou o projeto do edifício ao engenheiro italiano Filinto Santoro, autor também dos projetos do Colégio Gentil Bittencourt e do Mercado de São Brás. Santoro formou-se pela Real Escola de Nápoles, na Itália e trouxe referências do renascimento italiano, inclusive com os materiais utilizados na construção do Palácio, como o mármore utilizado nos capitéis das fachadas. Dessa forma, o gradil externo e 
as esquadrias, assim como alguns elementos decorativos e luminárias externas foram importados de Milão. Os forros são em madeira ou metal, ambos amplamente decorados. Os pisos são em madeiras regionais. Porém, o piso de cada sala difere, de acordo com a importância do ambiente. Sendo assim, os pisos do hall de entrada, e das varandas são em materiais diferentes, a da entrada em mosaico genovês, e o da varanda, em ladrilhos hidráulicos. O edifício é representante da arquitetura eclética em Belém.

O acesso ao edifício é feito por uma escada lateral, a qual conduz ao salão, onde é realizada a exposição temporária (Figura 41). Em outro ambiente, está localizada a escada em curva sinuosa, tornando essa área uma das mais atrativas do museu, a qual leva ao pavimento superior para a exposição do edifício com seu mobiliário (Figura 42). Outra opção é subir pelo elevador, incorporado ao edifício no ano de 2008.

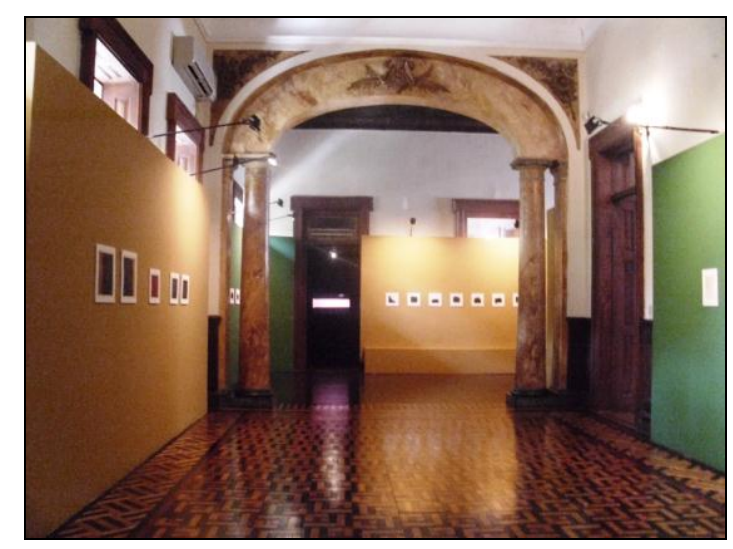

Figura 41. Salão de exposição do Museu da Universidade Federal do Pará.

Autor da Foto: Luciana Florenzano, 2011.

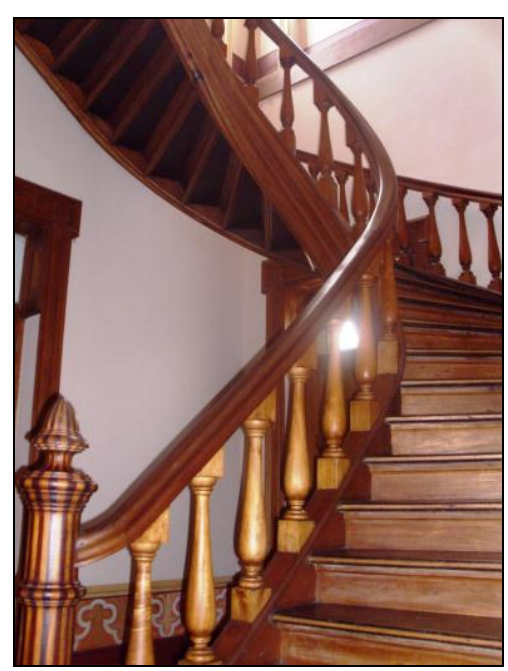

Figura 42. Escada do Museu da Universidade Federal do Pará. Autor da Foto: Luciana Florenzano, 2011. 
Se o visitante seguir no pavimento térreo, após um memorial dedicado a história da Universidade Federal do Pará, encontra-se o antigo escritório do governador Augusto Montenegro, onde atualmente além da visitação, é uma sala para eventos solenes, como lançamento de livros, e lançamento de novas exposições temporárias (Figura 43).

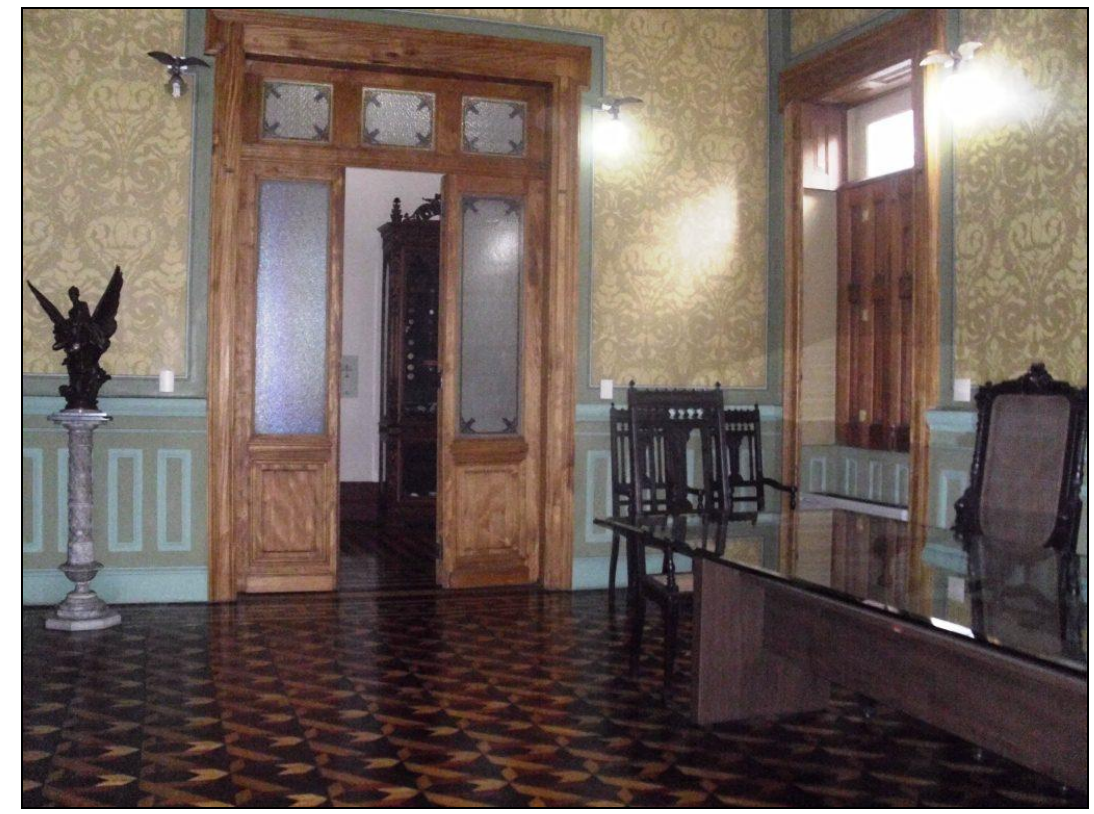

Figura 43. Escritório do governador Augusto Montenegro. Autor da Foto: Luciana Florenzano, 2011.

O prédio possui muitas portas e janelas para circulação de ar e iluminação natural. Os quartos antes eram todos interligados, característica arquitetônica do início do século XX. Para atual função, foram vedadas as circulações entre os ambientes. O Museu da UFPa possui uma área multi-uso para palestras, cursos e oficinas, além de uma sala multimídia, local também destinado a restauração de obras do acervo. Também são ministradas aulas do curso de Museologia dentro das dependências do museu.

O Museu tem biblioteca própria (Figura 44), instalada em uma espécie de porão, próximo a escada de acesso principal. A biblioteca possui um rico acervo, extremamente procurado por pesquisadores, principalmente em relação à coleção sobre a cultura da Amazônia, doada pelo professor Vicente Salles. Além de outros livros, periódicos, documentos, e recortes de jornais.

Do lado oposto aos acessos, existe um anexo do edifício, onde está situado o setor 
administrativo do museu, composto por dois pavimentos, sendo o primeiro destinado em grande parte à reserva técnica e o segundo a sala da direção (Figura 45).

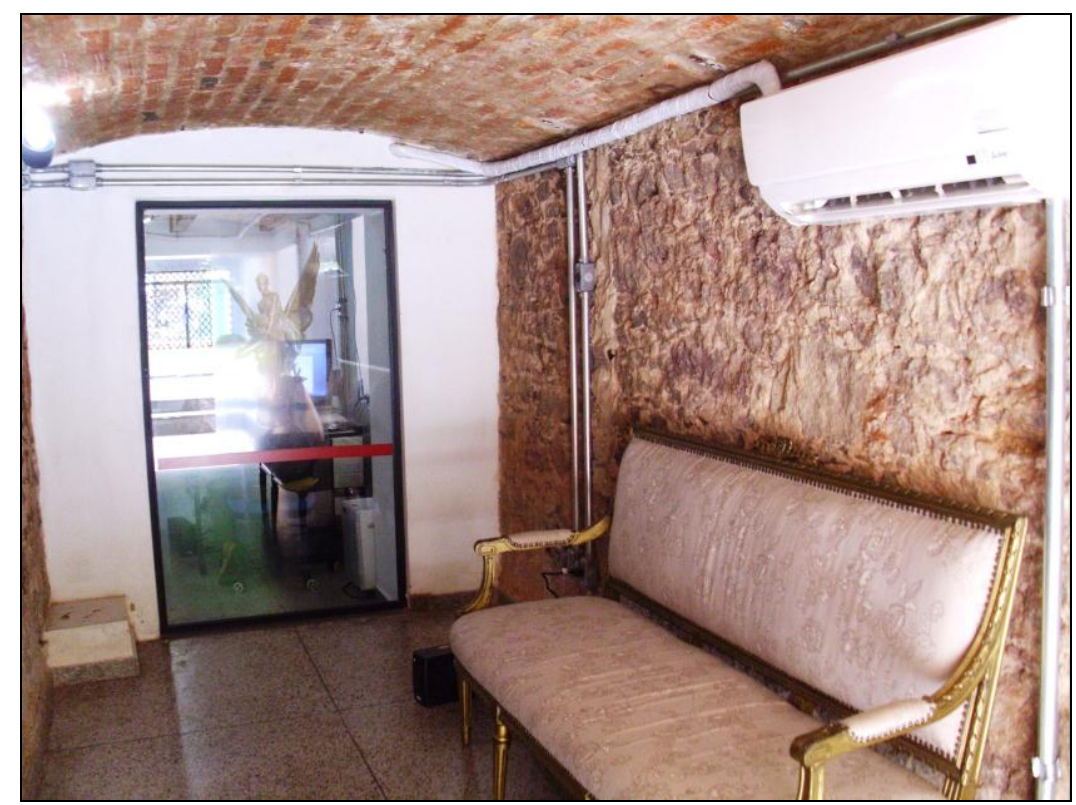

Figura 44. Biblioteca do Museu da Universidade Federal do Pará. Autor da foto: Luciana Florenzano, 2011.

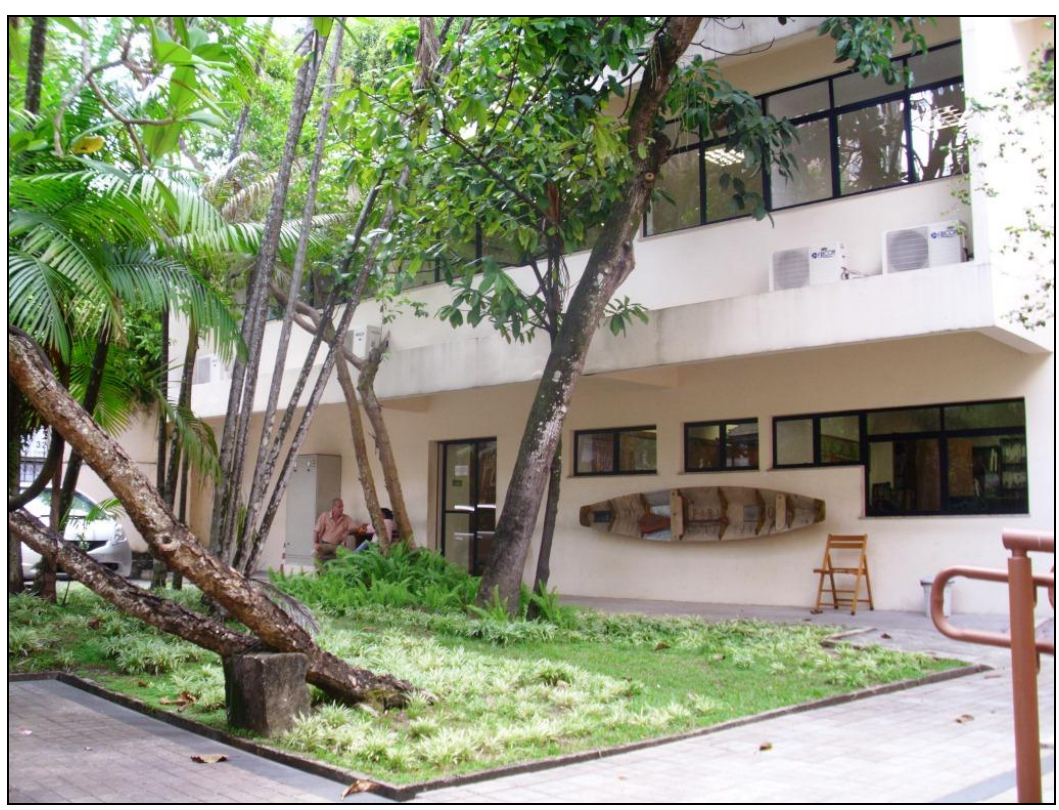

Figura 45. Anexo do Museu da Universidade Federal do Pará. Autor da foto: Luciana Florenzano, 2011.

O jardim data de um período posterior à construção do Palácio. Ele foi incorporado, entre os anos de 1948 e 1950, através da aquisição por parte da então família residente, de seis residências situadas na Av. Generalíssimo Deodoro, as quais foram demolidas para a 
construção do jardim neoclássico, com estátuas e um chafariz central (Figura 46).

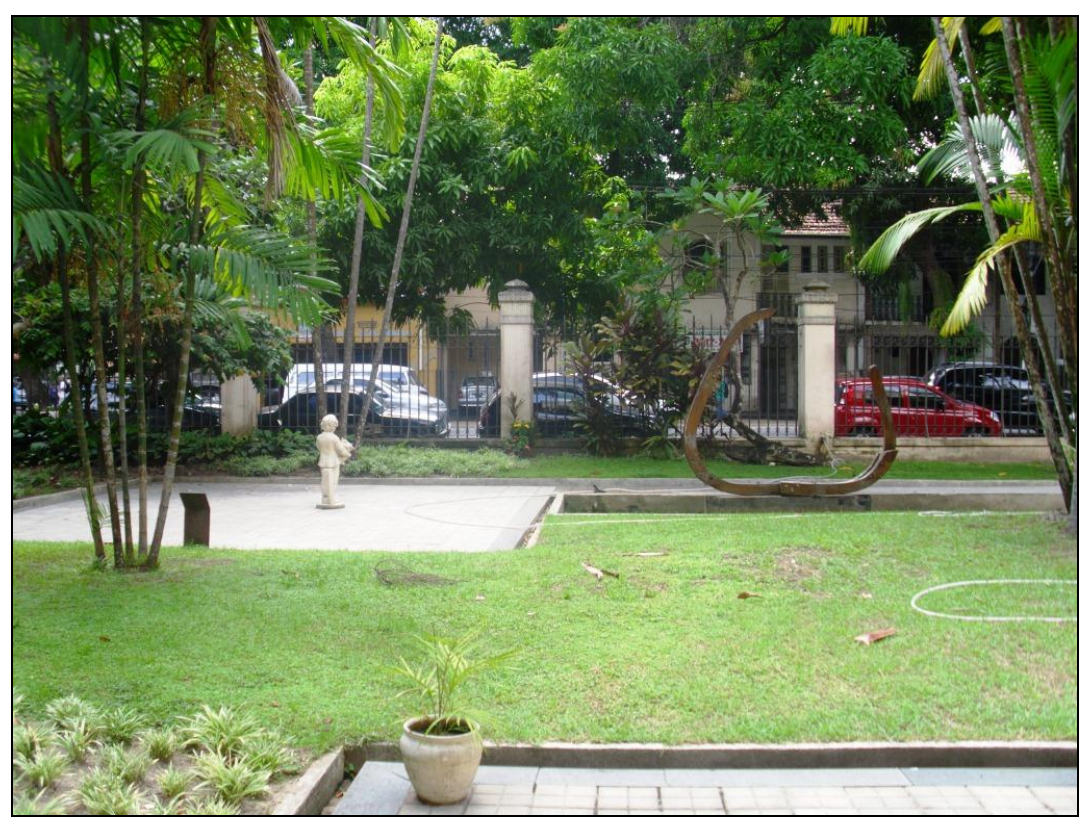

Figura 46. Jardim do Museu da Universidade Federal do Pará. Autor da foto: Luciana Florenzano, 2011.

\subsubsection{ACERVO}

O museu inicialmente não possuía acervo próprio. Porém, ao longo das últimas décadas foi adquirindo uma coleção variada relacionada às artes visuais e principalmente a arte contemporânea, por meio de pinturas, esculturas e desenhos, os quais permanecem guardados na reserva técnica do museu, de lá saindo eventualmente para exposições temporárias. O acervo em exposição permanente do museu caracteriza-se pelo próprio edifício em si, com seus lustres, pisos, revestimentos e mobiliário.

\subsection{CIÊNCIAS NATURAIS E HISTÓRIA NATURAL}

\subsubsection{MUSEU PARAENSE EMÍLIO GOELDI}

\subsubsection{HISTÓRICO}

O Museu Emilio Goeldi possui temática diferente das demais instituições da cidade de Belém. Trata-se do museu brasileiro mais antigo nesse gênero, sobre a fauna, a flora e a cultura amazônica.

O museu possui dois núcleos. Um setor de pesquisas, localizado na Av. Perimetral e o 
outro, o Parque Zoobotânico, criado em 1985. O parque originou-se do Museu Paraense, no ano de 1871, sob a direção do naturalista Domingos Soares Ferreira Pena. Entretanto, devido as suas condições precárias de funcionamento, o museu acabou sendo desativado com a morte de Ferreira Pena, em 1889. Quatro anos mais tarde, o então governador Lauro Sodré, acreditando no potencial do museu, convida um naturalista suíço, vindo do Rio de Janeiro, Emílio Goeldi para assumir a direção do museu, que passaria por uma reforma. Assim, com o devido investimento e adequação do museu as normas, é inaugurado em 1895 o parque zoobotânico. O parque se tornou referência nas pesquisas da região amazônica e em diversas publicações, conferências, etc. Por isso, em 1900 o governador Paes de Carvalho muda o nome do museu de Museu Paraense para Museu Paraense Emílio Goeldi.

De lá para cá, o museu ampliou seu acervo, e ganhou reconhecimento. Vinculou-se ao Conselho Nacional de Pesquisas (CNPQ) no início dos anos 50, do qual permaneceu até 2000, quando passou a ser subordinado ao Ministério da Ciência e Tecnologia do Brasil. Na década de 70, ampliou suas bases físicas, uma vez que o espaço do parque já não supria as necessidades do museu. Dessa forma, é criado o campus de pesquisa, localizado na Av. Perimetral. Atualmente, todas as pesquisas do museu são realizadas nesse campus, juntamente com a administração e a biblioteca, e lá se encontra a reserva técnica da instituição. No parque estão as exposições, tanto dos animais e da natureza, quanto de alguns artefatos relacionados à cultura amazônica.

\subsubsection{PARTIDO ARQUITETÔNICO E ARQUITETURA INTERNA}

O Museu Paraense Emílio Goeldi é uma das fontes de lazer da população de Belém. Ele possui um extenso conjunto arquitetônico e paisagístico, que compõem o parque zoobotânico. Além dos recintos dos animais, o parque possui monumentos espalhados ao longo de 5,2 hectares de área. No parque, além dos edifícios destinados a exposições, encontram-se a Diretoria da instituição, a coordenação de administração e museologia, a assessoria de comunicação social e a Editora do museu. O museu possui os seguintes edifícios, abertos ao público:

\section{- Prédio da rocinha}

Pavilhão Domingo Soares Ferreira Penna, logomarca do museu, é conhecido como prédio da Rocinha, pois no século XX, existiam perto da cidade de Belém, algumas casas de 
campo utilizadas para descanso, as quais eram chamadas de rocinhas (Figura 47). Assim, a rocinha do Museu Paraense Emílio Goeldi foi construída em 1879 para ser a residência de Bento José da Silva Santos. Porém, é adquirida pelo governo federal em 1895, para ser o local destinado ao Museu, criado em 1866 e ainda sem sede. Emilio Goeldi, então diretor do museu, transformou a Rocinha no local de instalação do acervo permanente, gabinete e biblioteca. Infelizmente, poucas rocinhas restaram em Belém, sendo a do museu, única para visitação (Figuras 48, 49, 50). O prédio sofreu duas restaurações, uma em 1970 e outra em 2003/2005. Atualmente, é o único prédio com exposições no parque.

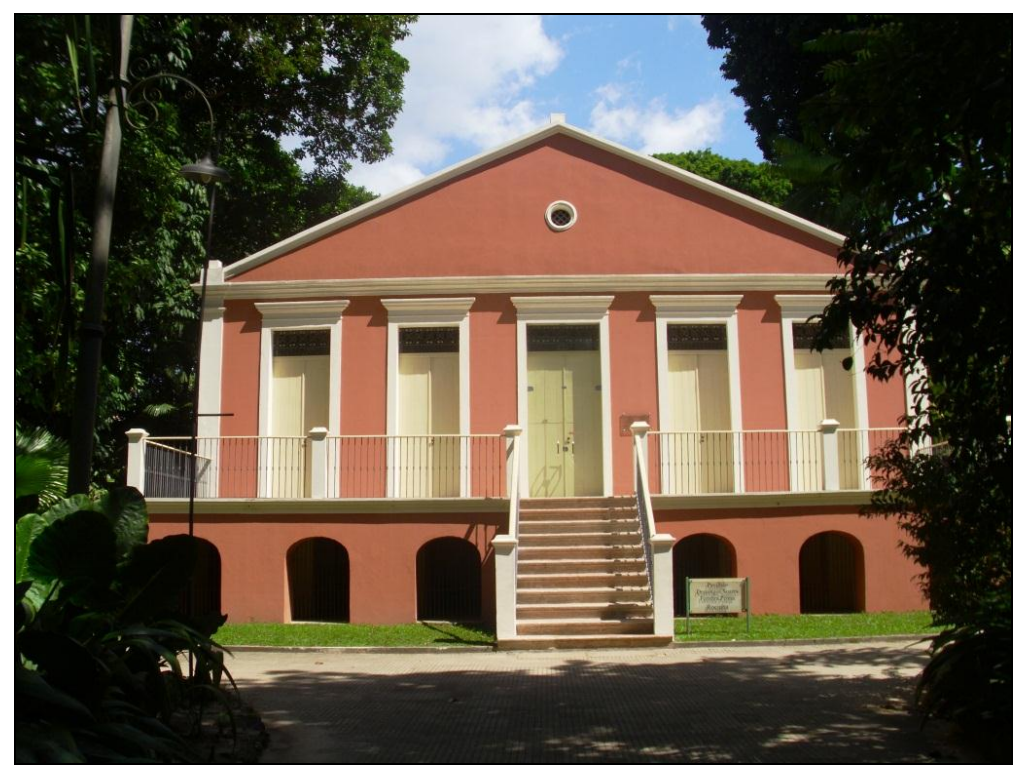

Figura 47. Pavilhão Domingo Soares Ferreira Pena (Prédio da Rocinha) do Museu Paraense Emílio Goeldi. Autor da foto: Luciana Florenzano, 2011.

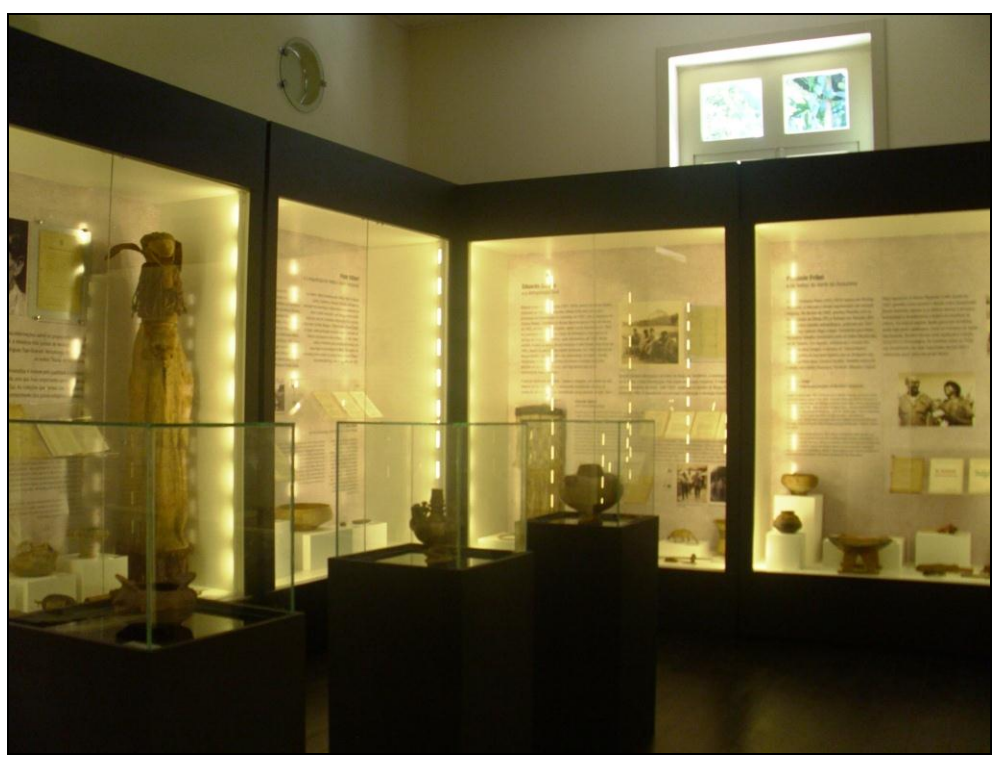

Figura 48. Exposição no Prédio da Rocinha do Museu Paraense Emílio Goeldi.

Autor da foto: Luciana Florenzano, 2011. 


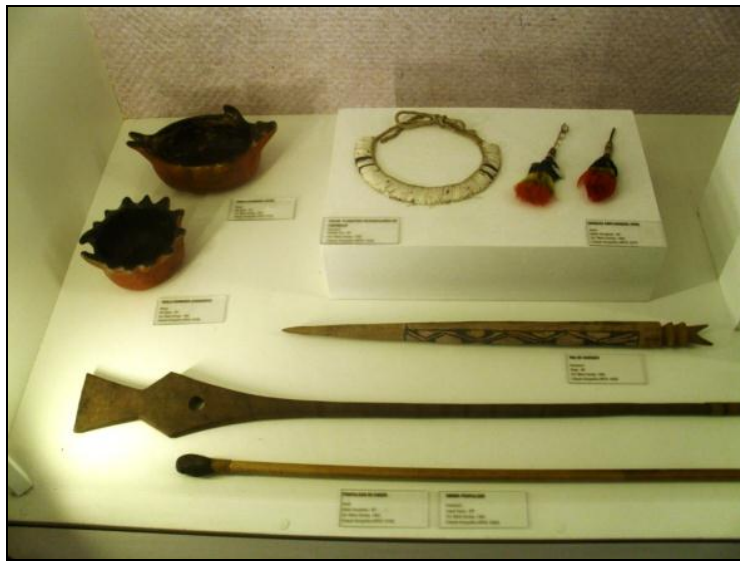

Figura 49: Artefatos arqueológicos em exposição no Prédio da Rocinha do Museu Paraense Emílio Goeldi.

Autor da foto: Luciana Florenzano, 2011.

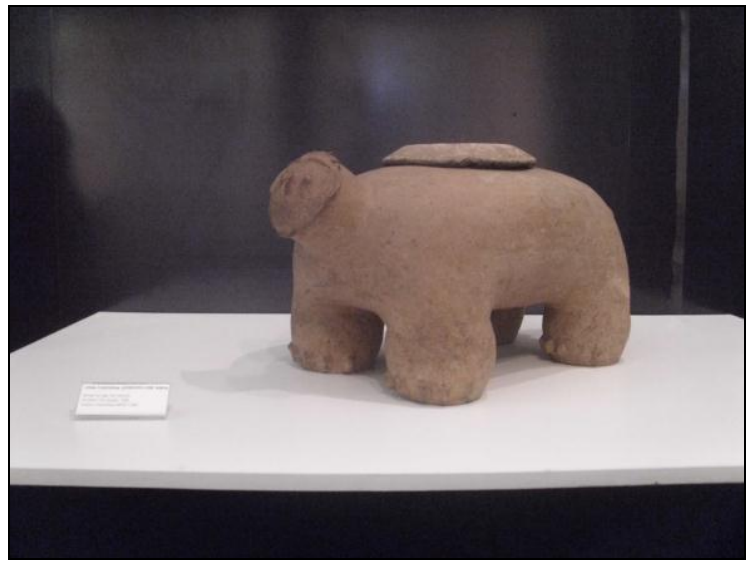

Figura 50: Artefatos arqueológicos em exposição no Prédio da Rocinha do Museu Paraense Emílio Goeldi.

Autor da foto: Luciana Florenzano, 2011.

\section{- Aquário Jacques Huber}

É o aquário público mais antigo do Brasil, foi inaugurado em 1911. Originalmente, seu partido arquitetônico seguia a linha art noveau, entretanto com as reformas e intervenções que o aquário sofreu, grande parte de seu partido foi descaracterizado (Figura 51).

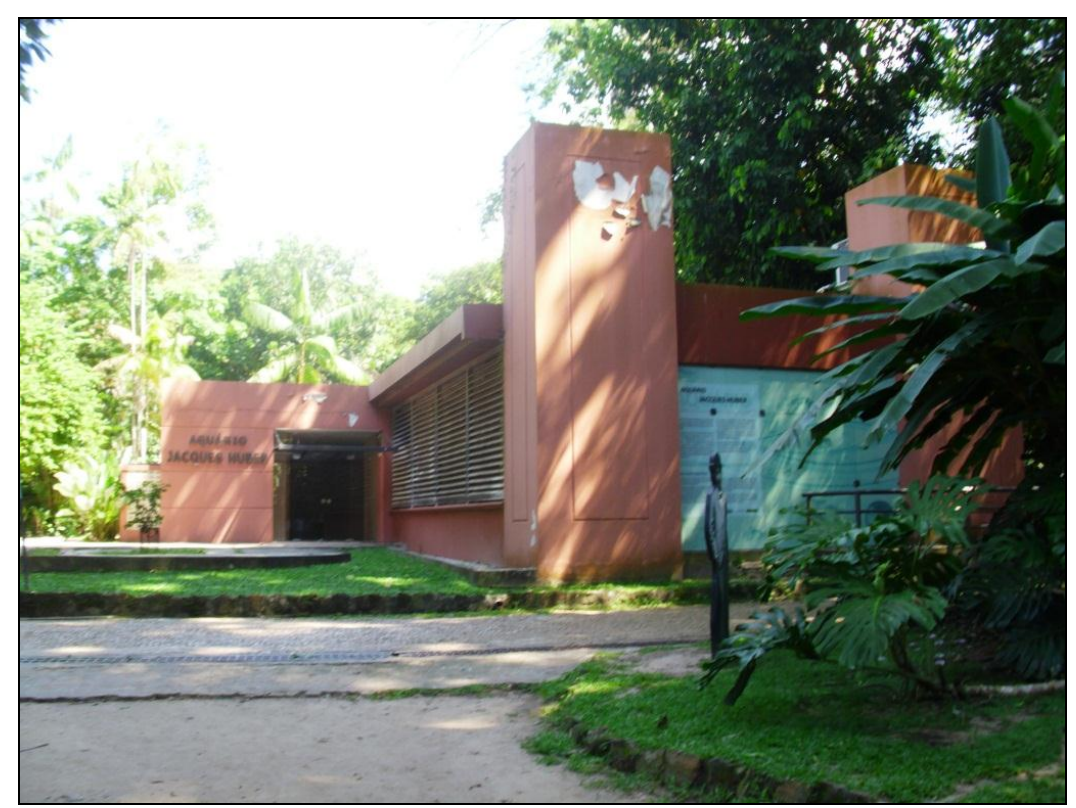

Figura 51. Fachada do Áquário Jacques Huber do Museu Paraense Emílio Goeldi.

Autor da foto: Luciana Florenzano, 2011. 
O aquário, que possuía esse nome em homenagem a Jacques Huber, diretor na época de sua construção, abriga peixes da região amazônica, além de serpentes e quelônios. Atualmente, o aquário está desativado.

\section{- Castelinho}

O Castelinho foi inaugurado em 1901 no parque, e era na verdade uma caixa d'água disfarçada, a qual se tornou grande atração. Emilio Goeldi idealizou o Castelinho como um mirante, do qual seria possível visualizar o parque todo. Atualmente, o castelinho ainda atrai muitos visitantes (Figura 52).

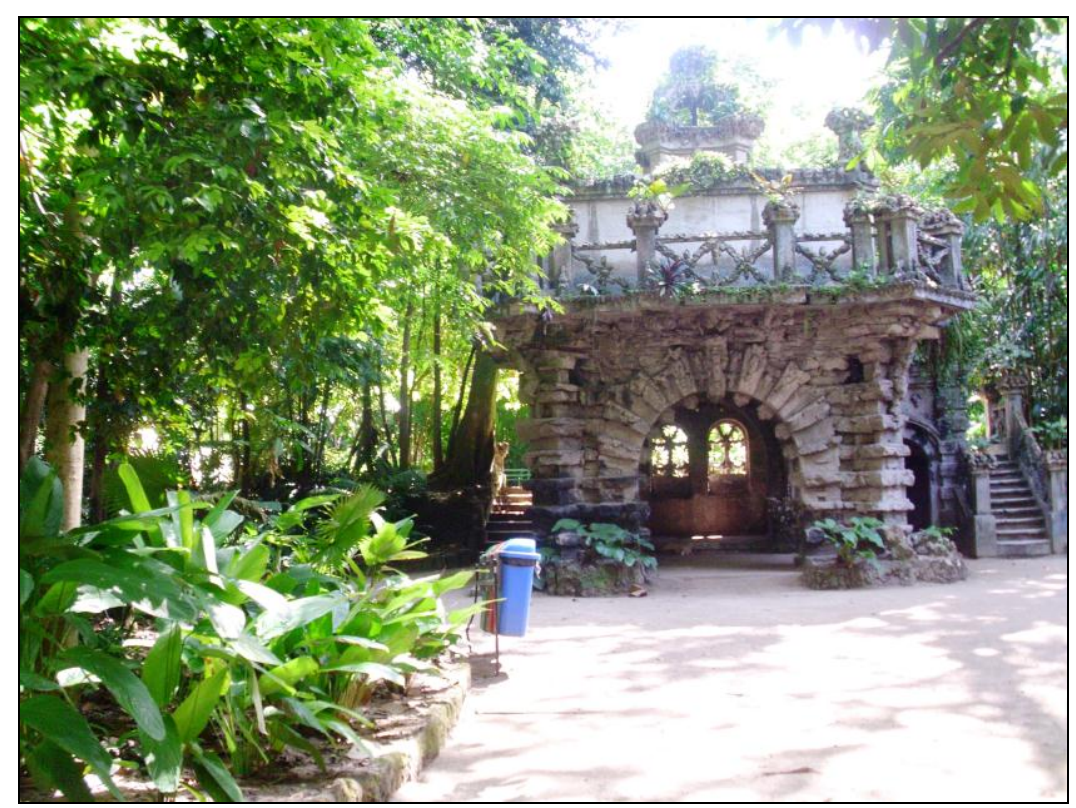

Figura 52. Castelinho do Museu Paraense Emílio Goeldi. Autor da foto: Luciana Florenzano, 2011.

\section{- Biblioteca de ciências clara maria galvão}

A biblioteca do Parque, cujo partido arquitetônico corresponde à arquitetura eclética produzida no século XIX em Belém, esteve no parque até o início da década de 80 e em 29 de agosto de 1987 foi instalada a biblioteca de Ciências Clara Maria Galvão, exclusiva para estudantes e professores do ensino fundamental e médio. Hoje em dia também funciona no prédio o serviço de Educação da Coordenação de Museologia e o clube do pesquisador mirim. 


\subsubsection{ACERVO}

O acervo do museu é composto por mais de mil animais, alguns em extinção, entre eles a onça pintada (Figura 53). Bem como inúmeros exemplares de animais empalhados, insetos, artefatos arqueológicos, entre outros. O parque contêm por volta de duas mil plantas, entre elas a árvore da castanha do Pará. O museu também possui animais que circulam livremente, como cutias, guarás, garças, preguiças, entre outros.

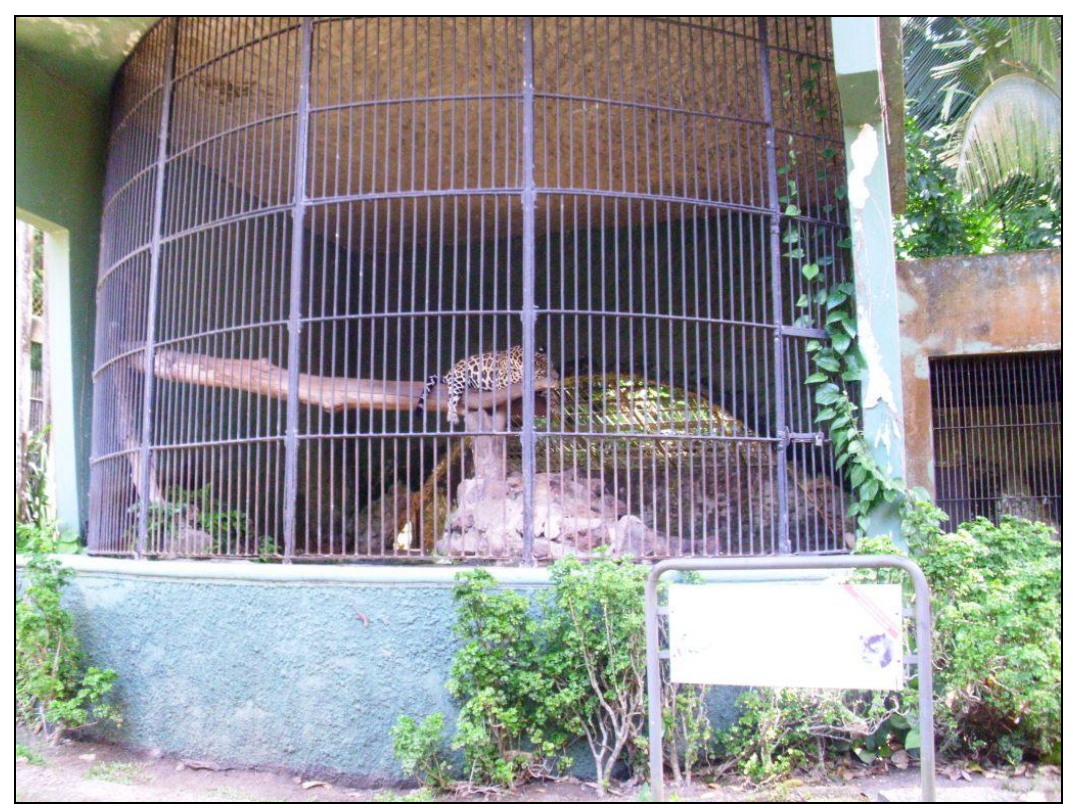

Figura 53. Onça pintada do Museu Paraense Emílio Goeldi. Autor da foto: Luciana Florenzano, 2011.

O parque, atualmente está bem equipado, possuindo além do entretenimento ao público, coleta seletiva do lixo, inclusive com lixeiras destinadas a pilhas e baterias descarregadas de máquinas fotográficas dos visitantes.

\subsubsection{MUSEU DE GEMAS (ESPAÇO SÃO JOSÉ LIBERTO)}

\subsubsection{HISTÓRICO}

Em 1749, os missionários franciscanos que residiam em Belém, construíram um 
convento dedicado a São José ${ }^{1}$, em um terreno doado por Hilário de Souza Azevedo, $13^{\circ}$ capitão-mor do Pará. Entretanto, menos de dez anos depois, os frades são expulsos, por ordem do Marquês de Pombal. A partir de então, o edifício deixou de ser convento, possuindo diversos usos ao longo de 85 anos. Foi transformado em um quartel, depois olaria, e hospital, até que em 1843 se tornou uma cadeia pública, para onde iam homens, mulheres e escravos. O edifício possuía capela com oratório, enfermaria e uma escola.

No ano de 1894, o então governador Lauro Sodré realizou a primeira reforma no edifício. A segunda aconteceu em 1926 e a terceira em 1943. Não se sabe exatamente a data, mas entre a década de 1950 e 1960, se tornou o presídio São José.

No governo de Almir Gabriel, em 2000, o presídio foi desativado e passou por um processo de restauração. Atualmente, no edifício funcionam o Museu de Gemas, a oficina de jóias e a casa do artesão. O Museu é uma das instituições que compõem o Sistema Integrado de Museus e Memoriais, criado pelo Governo do Pará, através da Secretaria de Cultura (SECULT).

\subsubsection{PARTIDO ARQUITETÔNICO E ARQUITETURA INTERNA}

O Espaço São José Liberto está localizado em frente à Praça Amazonas, no bairro do Jurunas em Belém (Figura 54). O edifício neocolonial possui paredes largas, em pedra e janelas que caracterizam o ritmo da edificação.

\footnotetext{
${ }^{1}$ José é um personagem bíblico, marido de Maria, mãe de Jesus Cristo. De acordo com a Bíblia José era carpinteiro e artesão.
} 


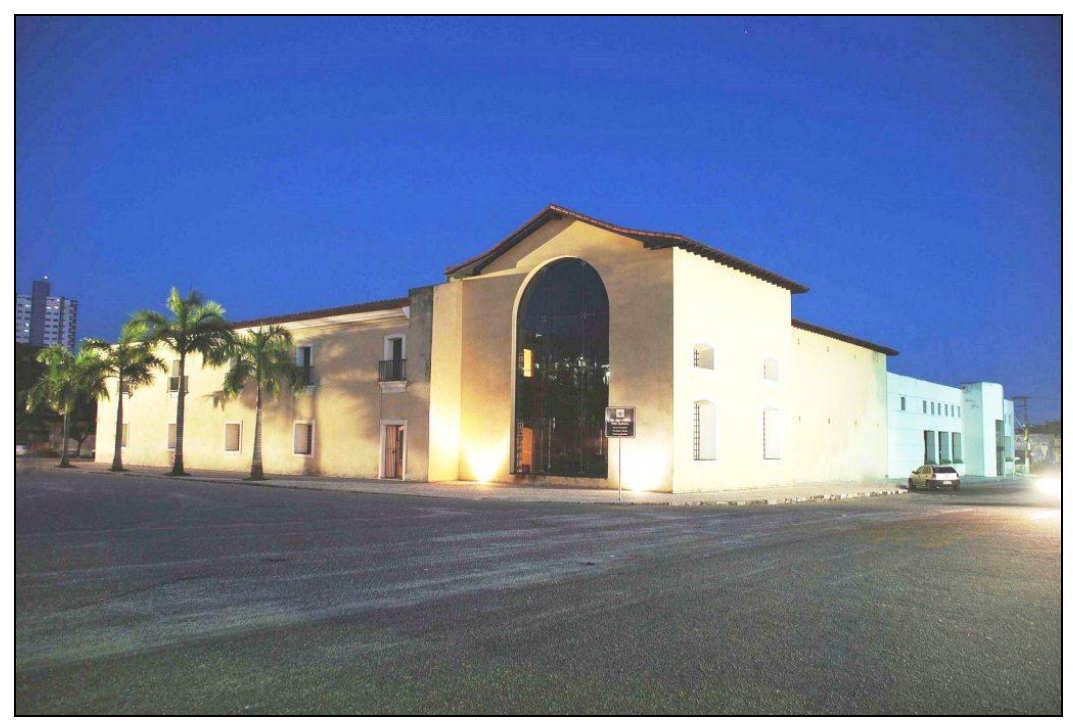

Figura 54. - Espaço São José Liberto.

Fonte: Google Imagens. Disponível em:

http://www.saojoselibertoigama.blogspot.com/p/o-espaco.html Acesso em: 20 set. 2011, 21:19.

Assim como os demais museus em Belém, ele foi adaptado para abrigar a função museal. Por essa razão, as salas de exposição, que antigamente eram as celas dos presos, tiveram a iluminação e ventilação natural vedadas. O museu segue a linha das instituições museais contemporâneas, e traz várias opções de entretenimento ao público visitante, que pode visitar a oficina de jóias (Figura 55) e conhecer o processo que o mineral passa até ser comercializado. O museu contêm também uma exposição do artesanato paraense (Figura56) além de um espaço destinado a apresentações teatrais e de dança, e eventos culturais, denominado Coliseu das artes (Figura 57).

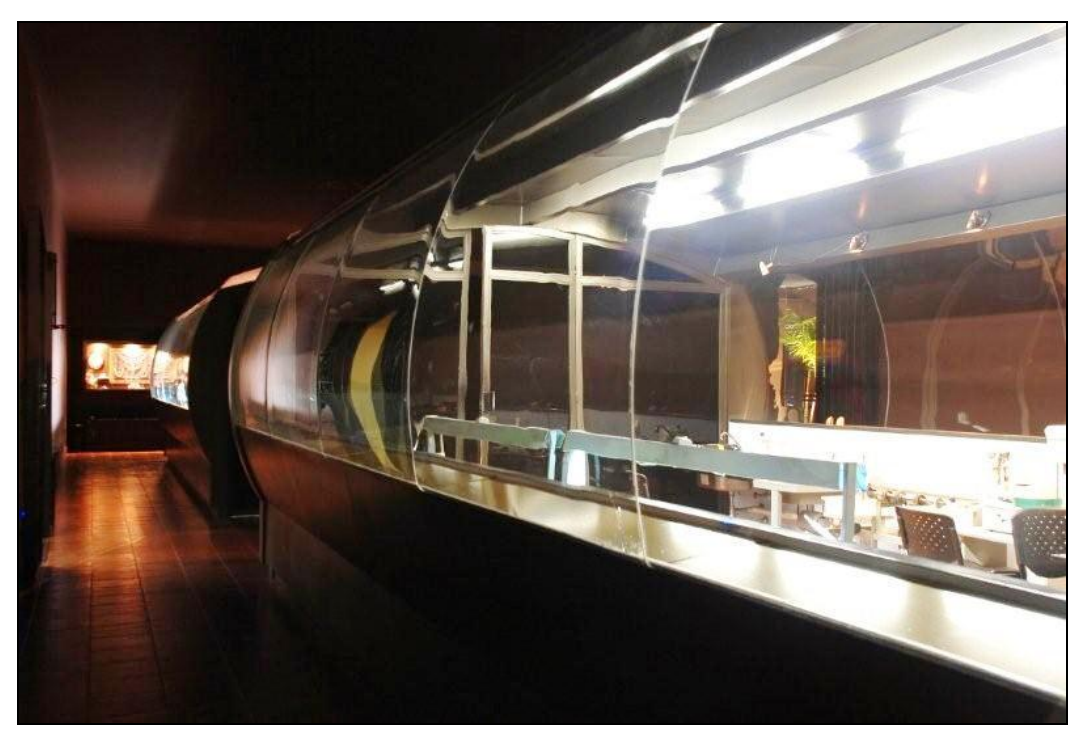

Figura 55. - Oficina de jóias. Espaço São José Liberto.

Fonte: Google Imagens. Disponível em:

http://www.saojoselibertoigama.blogspot.com/p/o-espaco.html

Acesso em: 20 set. 2011, 21:19. 


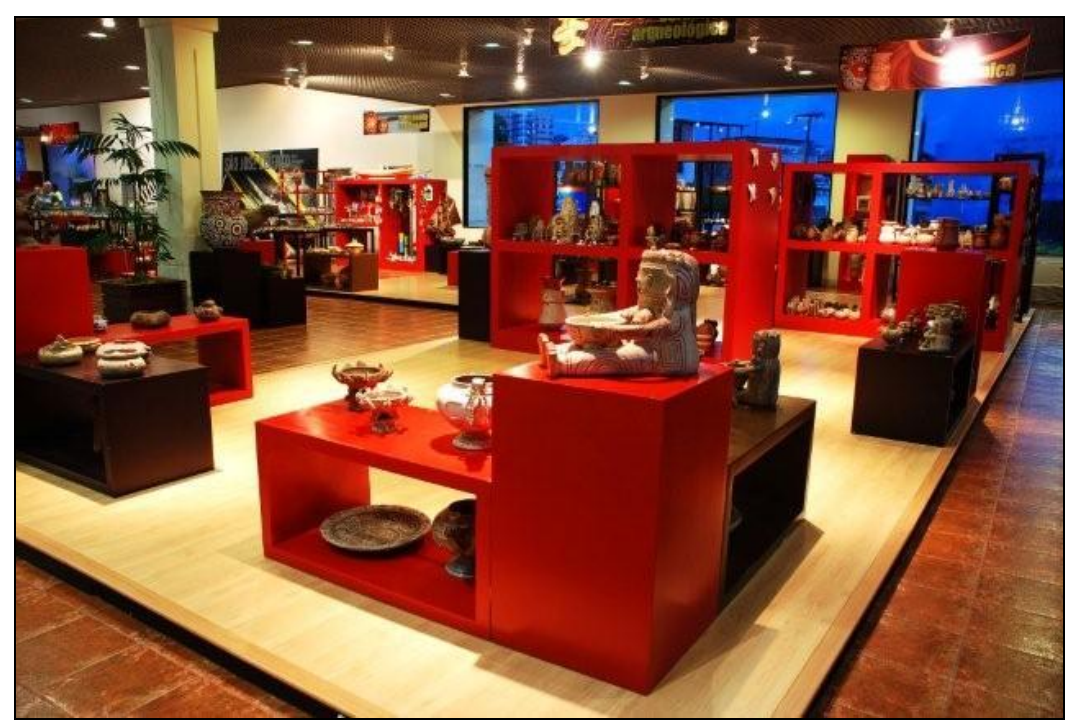

Figura 56. - Artesanato local exposto no Espaço São José Liberto. Fonte: Google Imagens. Disponível em:

http://www.saojoselibertoigama.blogspot.com/p/o-espaco.html Acesso em: 20 set. 2011, 21:19.

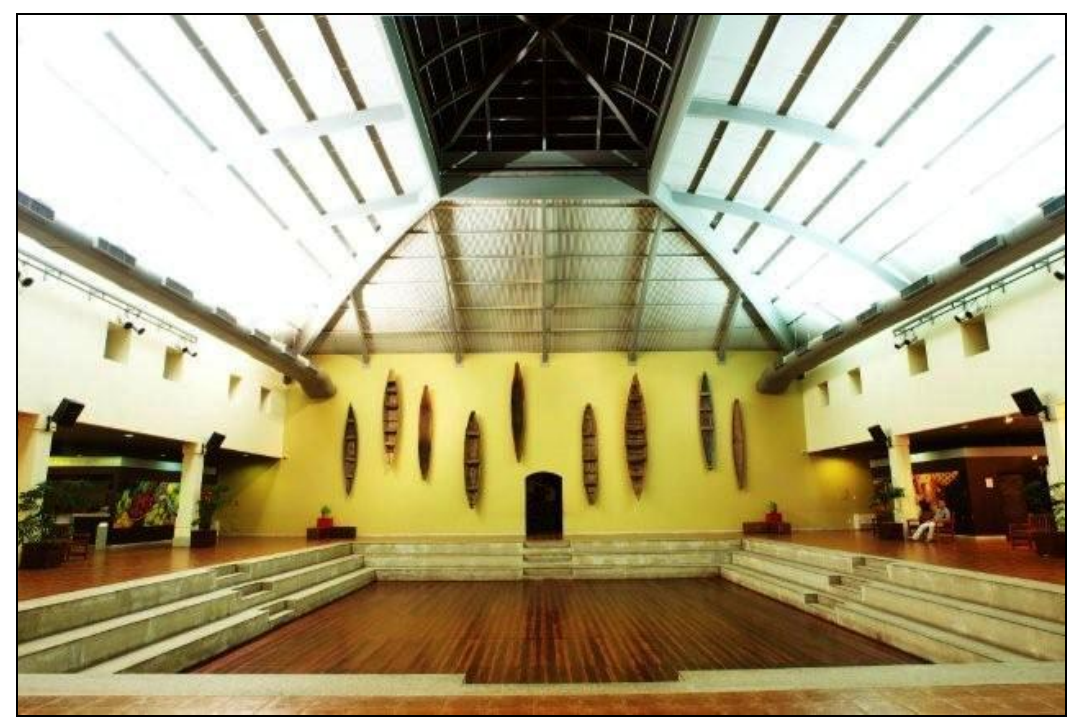

Figura 57. - Coliseu das Artes, Espaço São José Liberto.

Fonte: Google Imagens. Disponível em:

http://www.saojoselibertoigama.blogspot.com/p/o-espaco.html Acesso em: 20 set. 2011, 21:19

No pátio central do São José Liberto, está o Jardim da Liberdade, o qual recebeu paisagismo em harmonia com o museu. Ao redor do jardim, está a Casa do artesão, e a oficina de jóias. 


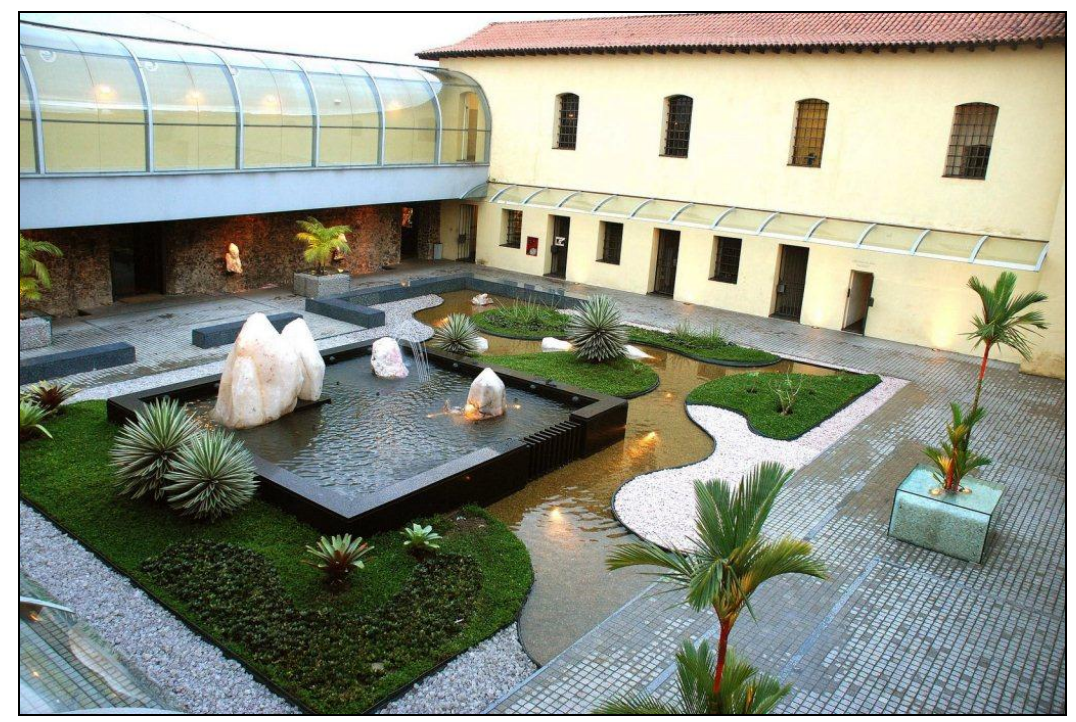

Figura 58. Jardim da Liberdade. Espaço São José Liberto. Fonte: Google Imagens. Disponível em: http://www.saojoselibertoigama.blogspot.com/p/o-espaco.html Acesso em: 20 set. 2011, 21:19.

\subsubsection{ACERVO}

O acervo do Museu possui por volta de quatro mil peças, dentre elas cerâmicas milenares, gemas minerais do Pará e de outras regiões da Amazônia e jóias produzidas pelos artistas que compõem o Polo Joalheiro. As gemas podem ser visualizadas tanto em estado bruto, quanto lapidado.

A exposição permanente acontece em cinco salas, próximas ao acesso principal do museu. O espaço antes abrigava as celas do presídio.

As salas que guardam a exposição se interligam e possuem as janelas vedadas. $\mathrm{O}$ caminho do visitante é planejado, de forma a obter a melhor compreensão sobre a coleção. Em um primeiro momento, a primeira sala é dedicada à ocupação humana na Amazônia, e consiste em artefatos arqueológicos, como lâminas de machados de pedras polidas, cunha de pedra polida, pedra picoteada, pontas de flechas confeccionadas com minerais, muiraquitãs, cerâmicas, vasos, entre outros artefatos diversos.

Nas salas seguintes, é possível visualizar um histórico das gemas e do ouro na Amazônia, com exemplares de materiais gemológicos naturais formados pela natureza, como diamantes, esmeraldas, quartzos, turmalinas, e ametistas. A sala expositiva também mostra ao visitante a história da mineração no Brasil. 
A última sala é dedicada às gemas paraenses, e a história do ouro no Pará (Figura 59).

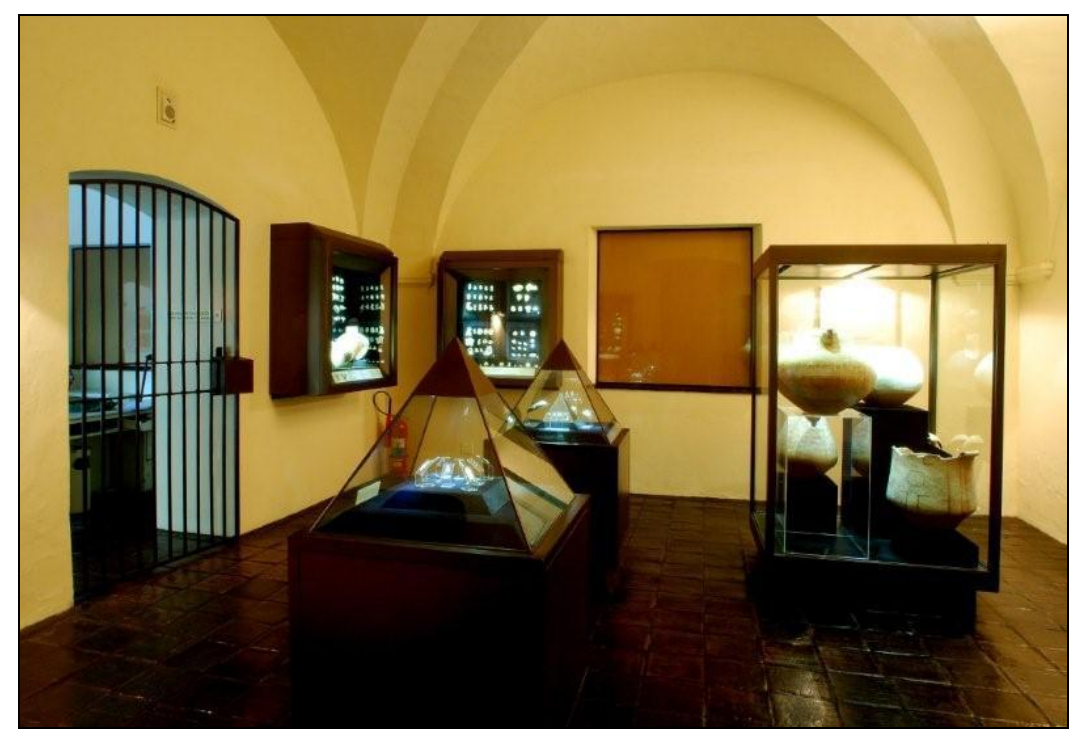

Figura 59. Exposição permanente. Espaço São José Liberto. Fonte: Google Imagens. Disponível em: http://www.saojoselibertoigama.blogspot.com/p/o-espaco.html. Acesso em: 20 set. 2011, 21:19 


\section{MUSEU DE GEOCIÊNCIAS DA UNIVERSIDADE FEDERAL DO PARÁ}

\subsection{HISTÓRICO DO INSTITUTO DE GEOCIÊNCIAS}

A partir da segunda metade do século XX no Brasil, a região da floresta Amazônia se consolidou como sítio mineralógico, devido as grandes descobertas de inúmeros bens minerais. Na década de 1950, foi descoberto ouro no rio Tapajós, gerando a grande leva de imigrantes para essa região e em meados dos anos 60 os geocientistas encontraram grandes jazidas de bauxita e caulim. Tais fatos abriram as portas para o investimento do governo voltado as pesquisas geológicas e prospecção de minérios, entre 1970 e 1980. Foi a época do auge das descobertas na floresta e projetou mundialmente a região. Os anos 80 foram marcados pela descoberta de ouro em Serra Pelada, atual distrito de Curionópolis, no sudeste do estado do Pará. Tal descoberta culminou em uma migração humana sem precedentes na história da extração mineral, tornando Serra Pelada o maior garimpo a céu aberto do mundo. Com o decorrer dos anos, foram sendo encontrados inúmeros sítios naturais que possuíam vastos depósitos de pedras naturais.

Atualmente, a floresta amazônica continua fornecendo uma grande quantidade de bens minerais, entre eles alumínio, ferro, manganês, ouro, cromo, caulim, calcário, brita, seixos, pedras preciosas e pedras ornamentais.

Paralelo a essas descobertas mineralógicas, foi fundada em Belém, capital do estado do Pará, em 02 de julho de 1957, a Universidade Federal do Pará, que consistia no agrupamento de cinco faculdades, que já existiam em Belém, sendo elas as faculdades de Direito, Medicina, Odontologia, Farmácia e Engenharia.

O curso de Geologia é criado em 23 de Dezembro de 1963, com início das aulas em 1964, ministradas em dois casarões localizados no centro histórico de Belém. Já no ano de 1965, é criado o Núcleo de Geociências, órgão que compreendia o curso de Geologia e Geografia. Em 1970 foi inaugurado o atual campus da Universidade (Figura 60) localizado no bairro do Guamá. Com a nova localização, o curso de Geologia separou-se do curso de Geografia, passando a ser gerido pelo Centro de Ciências Exatas e Naturais. 


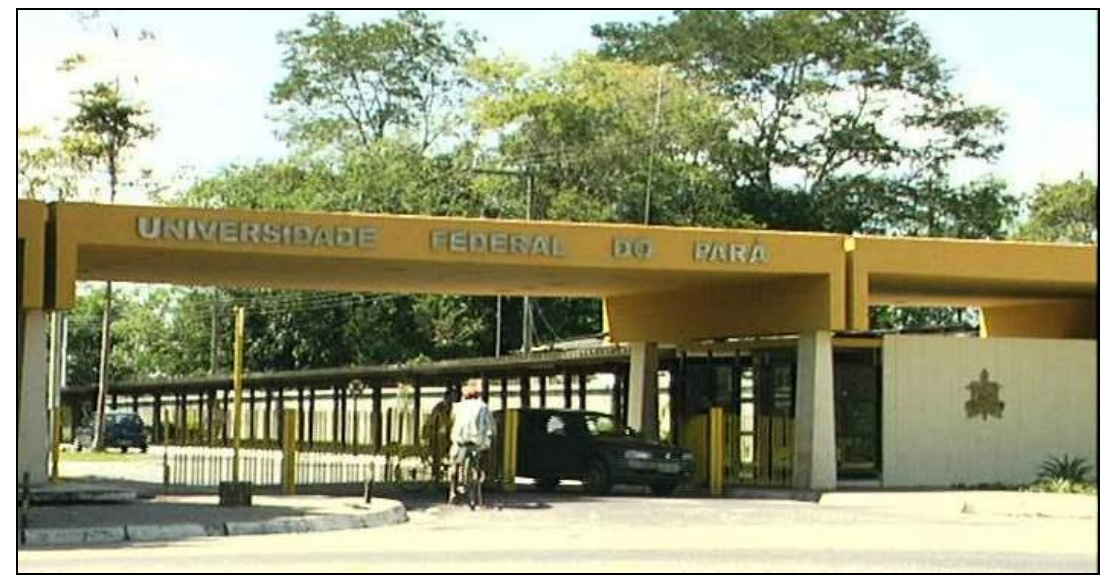

Figura 60. Universidade Federal do Pará.

Fonte: Google imagens. Disponível em:

http://www.portal.ufpa.br/interna_minutodauniversidade.php?idMinuto=60.

Acesso em: 17 ago. 2011, 11:43.

O avanço das descobertas na Amazônia e dos diversos investimentos nesse setor demandavam cada vez mais profissionais especializados, aumentando dessa forma a procura do curso de Geologia na UFPa, assim o mesmo teve um aumento significativo em termos de qualidade, com a inserção de novos profissionais vindos de outras regiões. Ao longo dos anos o curso de Geologia foi adquirindo espaço dentro do campus da Universidade.

Com o crescimento do curso, houve investimento financeiro de diversas agências, como o Conselho Nacional de Desenvolvimento Científico e Tecnológico (CNPq), a Coordenação de Aperfeiçoamento de Pessoal de Nível Superior (CAPES), e a Superintendência de Desenvolvimento da Amazônia (SUDAM).

Tais organizações trouxeram recurso financeiro para construção da infraestrutura necessária de apoio as pesquisas na área das Geociências, através de novos equipamentos e a construção de laboratórios, e então é criado em 1975 o Centro de Geociências da UFPA. A nova estrutura comportava os cursos de Geologia e Meteorologia, e o programa de pósgraduação em Geofísica, se separando assim, das Ciências Exatas e Naturais. Desde 2007, com o novo regimento geral da Universidade, o Centro de Geociências passou a ser Instituto de Geociências, composto pelas faculdades de Geologia, Geofísica, Meteorologia, e Oceanografia, e os programas de graduação em Geologia/Geoquímica, Geofísica e Ciências Ambientais.

Desde sua criação até a condição atual de Instituto de Geociências, a Universidade 
formou uma extensa quantidade de profissionais voltados para a área de Geociências. Atualmente, o Instituto conta com uma boa estrutura acadêmica, administrativa e científica. Possui diversas pesquisas relacionadas às Geociências e vários laboratórios, como de microscopia eletrônica de varredura, análises químicas, hidrogeologia, caracterização mineral e sedimentologia, além de laboratórios meteorológicos e geofísicos, entre outros mais específicos. O Instituto conta também com uma biblioteca setorial (Figura 61) e um auditório. Assim, o Instituto de Geociências da UFPa é atualmente uma instituição acadêmica com extensa contribuição para o desenvolvimento do estado do Pará, por meio da qualificação dos profissionais, das pesquisas e de um grande acervo geológico.

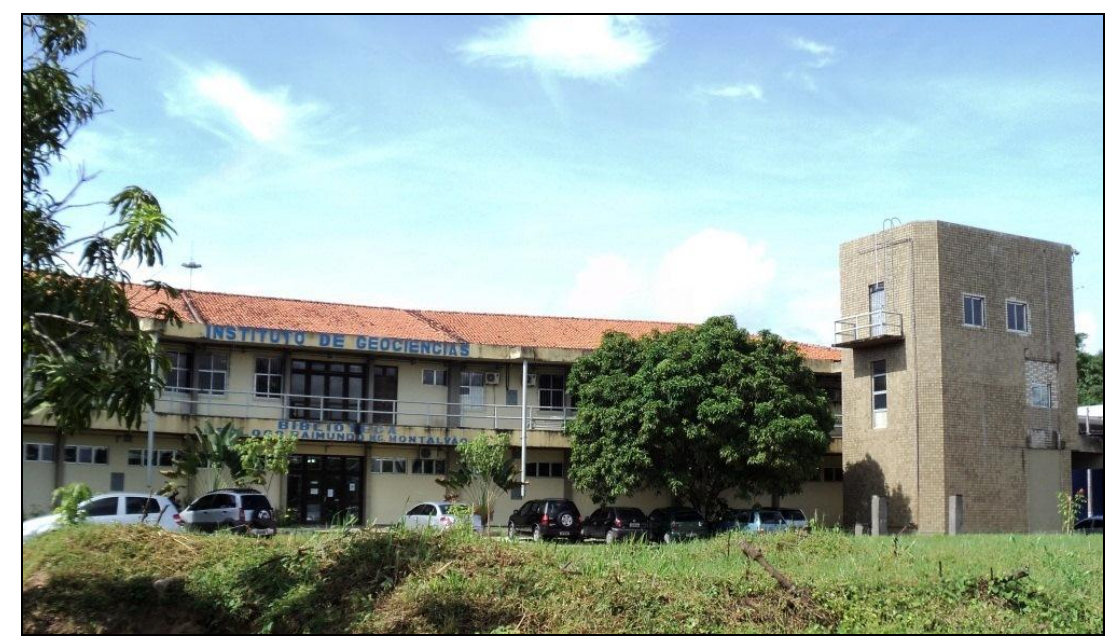

Figura 61. Instituto de Geociências e biblioteca setorial. Autor da foto: Luciana Florenzano, 2010.

Para difundir todo o conhecimento mineralógico da floresta Amazônia e de outras regiões do Planeta, surgiu e se desenvolveu um museu no Instituto de Geociências.

\subsection{HISTÓRICO DO MUSEU DE GEOCIÊNCIAS}

A origem do museu tem inicio em 1973, com a criação do programa de pós-graduação em geofísica, que atraiu novos profissionais para compor o corpo docente, entre eles o professor Manuel Gabriel Siqueira Guerreiro, locado no departamento de Geologia. O professor Guerreiro realizou o primeiro passo para a criação do museu, com a doação de peças particulares para a Universidade. Em seguida, outros professores e alunos doaram novas amostras, as quais foram catalogadas pelo então estudante Marcondes Lima da Costa. Paulatinamente, o museu vai aumentando sua coleção. Por volta de 1978 o acervo já possuía 300 peças, misturadas entre minerais extraídos da região amazônica e outros advindos de outros países, como as amostras adquiridas nos Estados Unidos, doadas pelo professor José 
Carlos Raimundo.

Em 1983, agora como professor, Marcondes Lima da Costa, fica responsável pela organização da coleção, analisando o acervo para identificação, catalogação e ampliação do mesmo, com investimentos do Conselho Nacional de Desenvolvimento Científico e Tecnológico (CNPq). Com a ajuda de várias pessoas, em 21 de dezembro de 1984, o museu foi inaugurado, localizado no mesmo prédio que o laboratório de geologia, e uma das construções mais antigas da Universidade Federal do Pará, executada pela Superintendência de Desenvolvimento da Amazônia (SUDAM).

O museu possui um vasto acervo de minerais, reunidos durante quase 50 anos do curso na Universidade. É notória a sua importância, pois a população da cidade de Belém é carente de informações sobre os recursos minerais da região. Logo, por meio do museu, e das pesquisas realizadas pelo Grupo de Mineralogia e Geoquímica Aplicada (GMGA), coordenado pelo professor Marcondes Lima da Costa, é possível aproximar mais a população local da importância das Geociências no contexto econômico atual, da gama de minerais que a floresta amazônica possui e das aplicações dos minerais no cotidiano local. O GMGA tratase do primeiro grupo na região da Amazônia com o objetivo de aplicar técnicas mineralógicas e geoquímicas aos problemas e materiais naturais e industriais encontrados na Amazônia.

Desde sua criação, o museu ocupa uma área de $100 \mathrm{~m}^{2}$, localizada em um dos blocos que constituem o parque geocientífico do Instituto de Geociências, dentro da Cidade Universitária José da Silveira Netto (Figura 62).

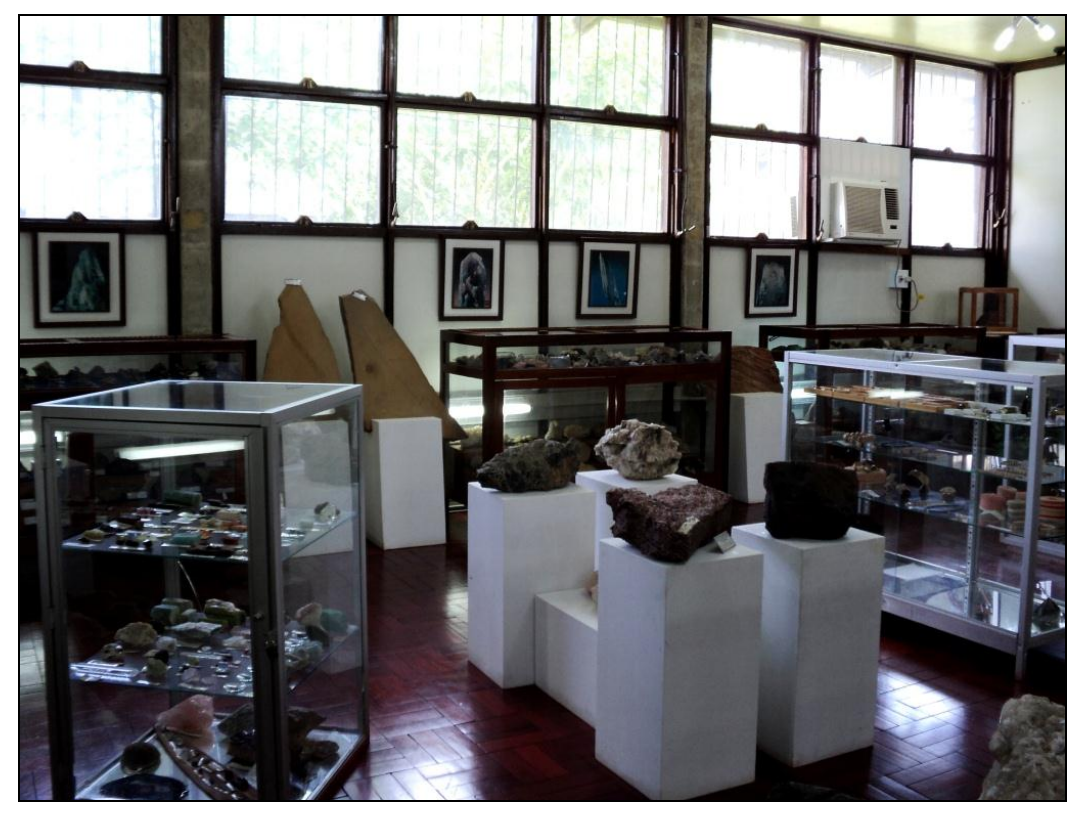

Figura 62. Museu de Geociências da UFPA.

Autor da foto: Luciana Florenzano, 2010. 


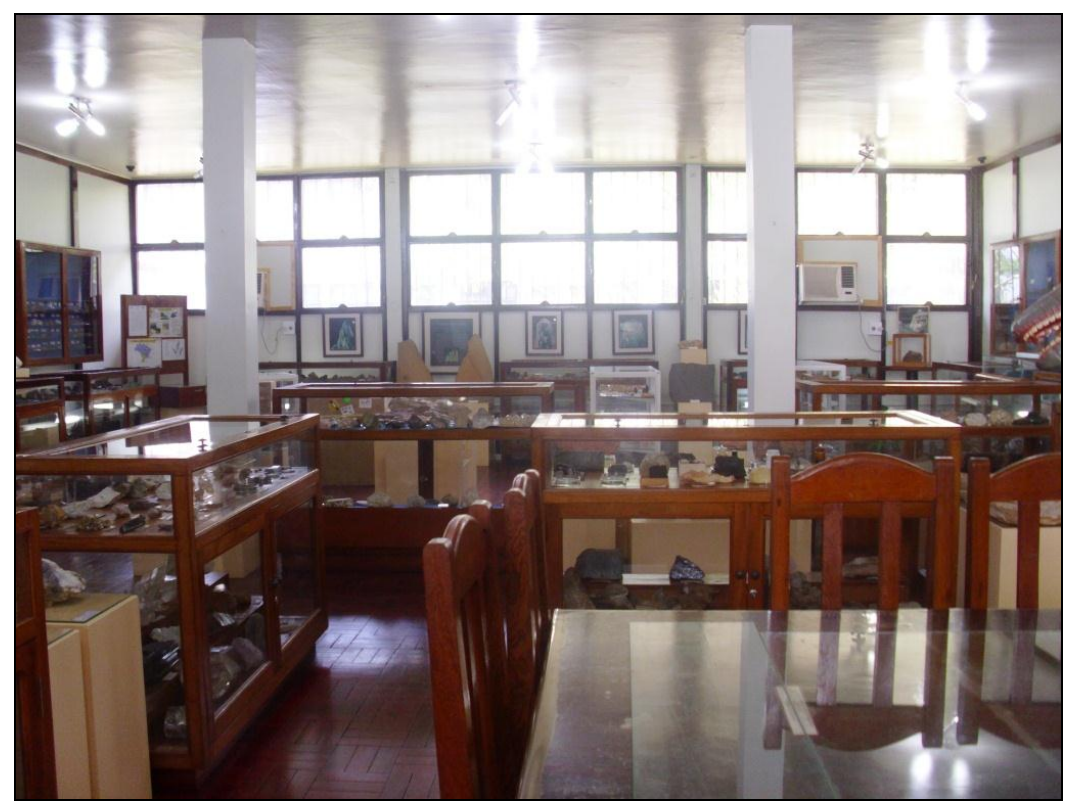

Figura 63. Museu de Geociências da UFPA. Autor da foto: Luciana Florenzano, 2010.

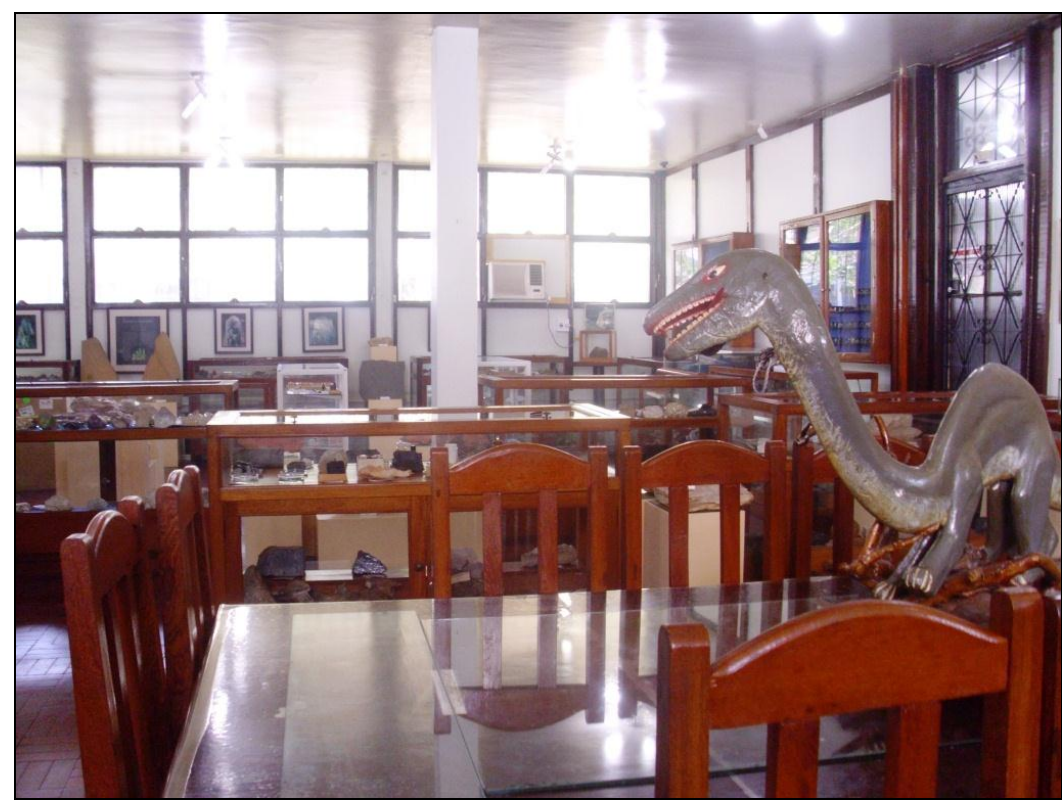

Figura 64. Museu de Geociências da UFPA. Autor da foto: Luciana Florenzano, 2010.

\subsection{ACERVO DO MUSEU}

O atual acervo possui 2.361 peças, constituídas em grande parte de amostras de minerais, rochas, cristais, gemas e fósseis da região Amazônica, entre outros minérios encontrados fora do país e mapas pertencentes ao Instituto de Geociências da Universidade Federal do Pará. 
Como o espaço físico é reduzido, o acervo está localizado no corredor de entrada e em uma sala climatizada no interior da edificação. Apesar do espaço limitado em que as peças estão situadas, elas estão agrupadas de acordo com sua natureza mineralógica e divididas em duas tipologias de exposições.

\subsubsection{EXPOSIÇÃO PERMANENTE}

A exposição permanente do Museu de Geociências da UFPA conta com a maior parte do acervo e aborda aspectos relacionados à difusão das geociências, além de uma secção determinada a história do curso.

Nessa exposição o público pode visualizar diferentes mapas geológicos da região amazônica e do resto de Brasil, dentre eles:

- Mapa geológico do Brasil (Figura 65).

- Mapa da Amazônia Legal com localização das suas principais jazidas, depósitos e ocorrências minerais.

- Documentário fotográfico e amostras de rochas do espetacular garimpo de ouro de Serra Pelada.

- Fotografias e pôsteres de minerais, fósseis e cavernas.

- Coluna crono e litoestratigráfica composta da Bacia do Amazonas. Trabalho em conjunto com a Petrobrás-Belém.

- Coluna litoestratigráfica de Nova Olinda-AM, com ênfase ao depósito de silvinita. Doação da Petromisa-Belém.

- Mapa geológico do Pará, organizado por KATZER, em 1903 (Figura 66).

- Mapa Geológico da região de Pirocaua, Maranhão, datado de 1956.

- Mapa Geológico do Brasil, de 1938.

- Geológical Time Table. 


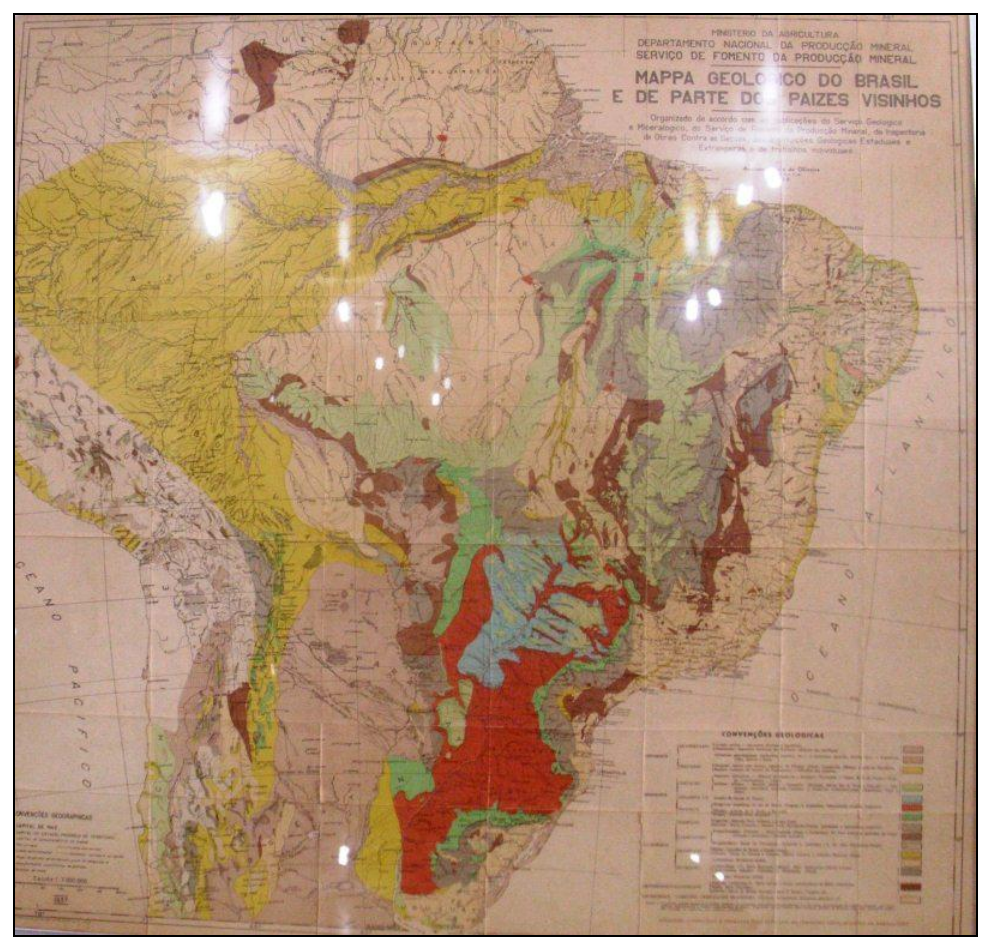

Figura 65. Mapa Geológico do Brasil. Acervo do Museu de Geociências da UFPA.

Autor da foto: Luciana Florenzano, 2011.

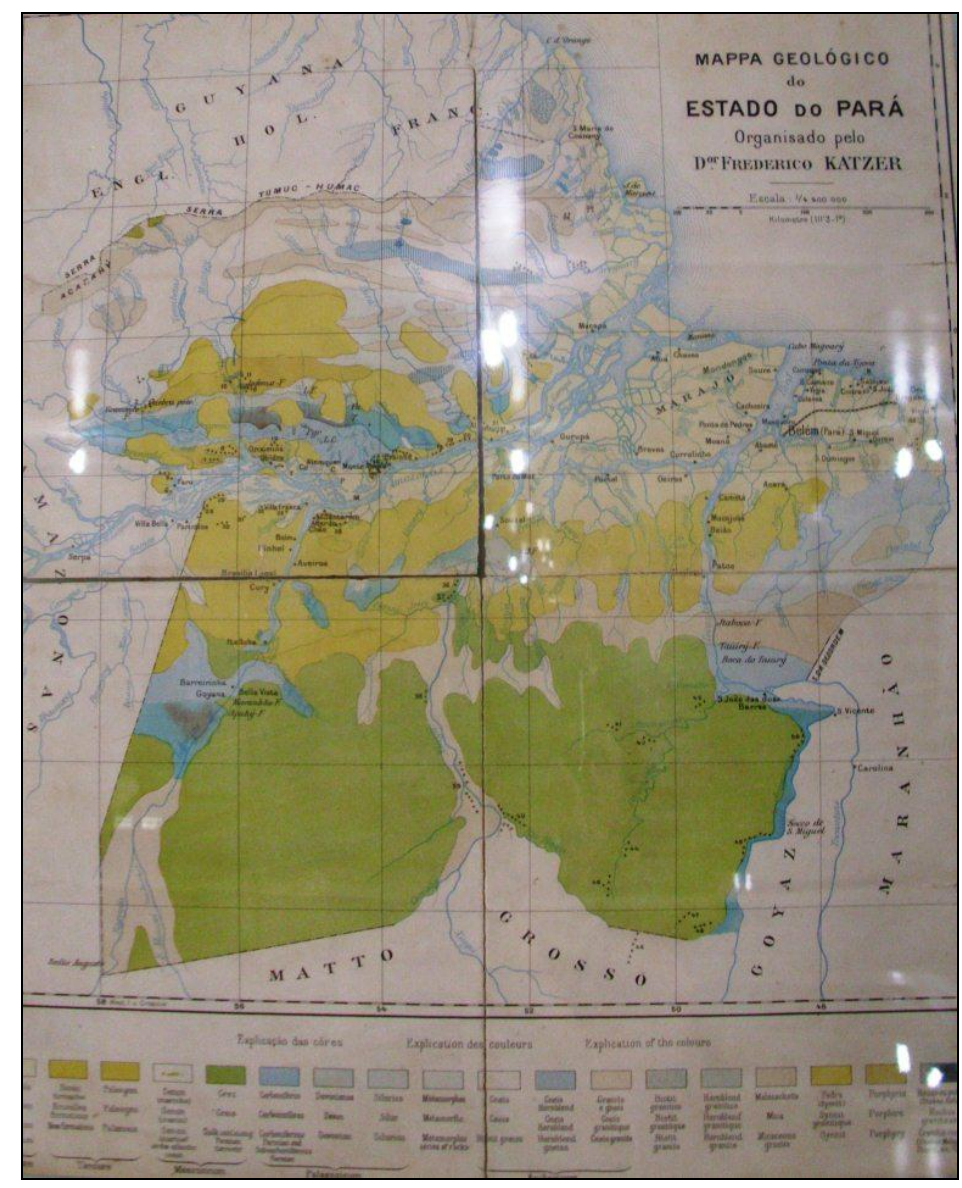

Figura 66. Mapa Geológico do Estado do Pará. Acervo do Museu de Geociências da UFPA.

Autor da foto: Luciana Florenzano, 2011. 
O acervo do museu também possui inúmeros exemplares de minerais e rochas, divididos nos seguintes segmentos:

- Miscelânea Geológica: minerais, rochas regionais e exóticas; ligas artificiais (Figura 67, 68, 69,70, 71, 72, 73 e 74).

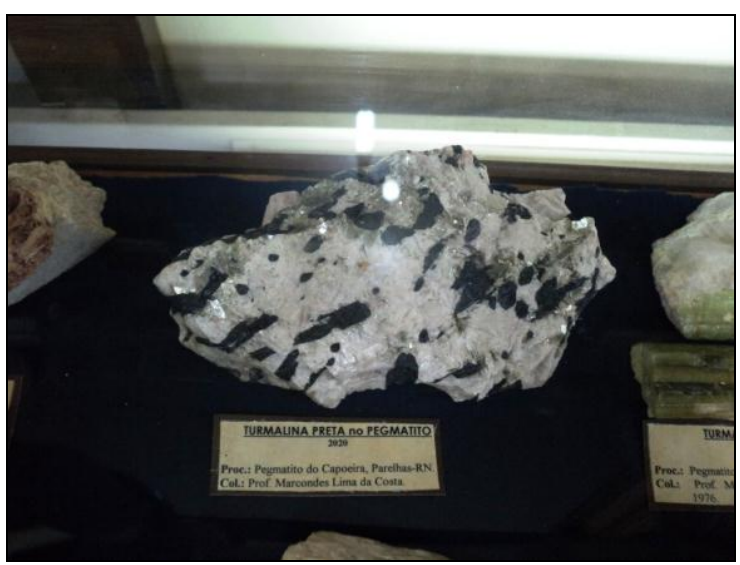

Figura 67: Turmalina preta do Museu de Geociências da UFPA.

Autor da foto: Luciana Florenzano, 2011.

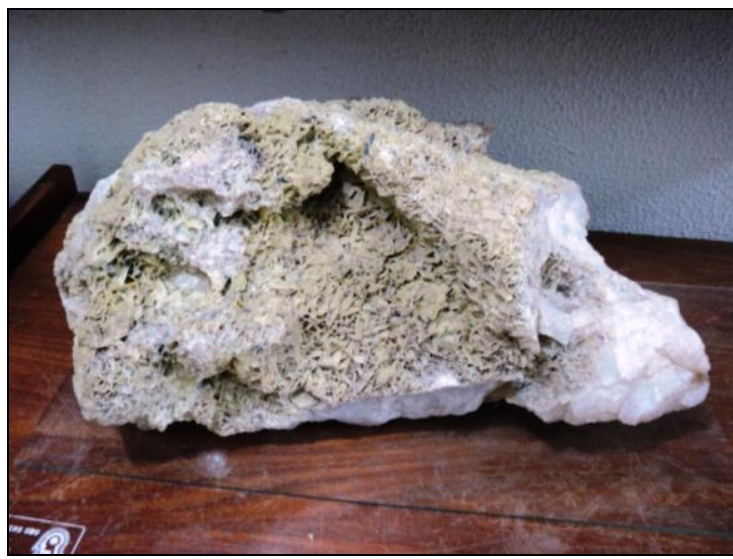

Figura 69: Calcita placosa e tridimita sobre quartzo do Museu de Geociências da UFPA.

Autor da foto: Luciana Florenzano, 2011.

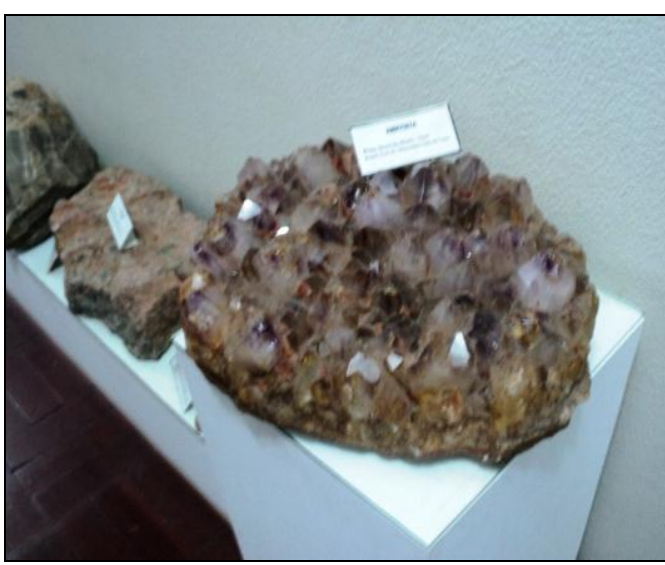

Figura 68: Ametista do Museu de Geociências da UFPA.

Autor da foto: Luciana Florenzano, 2011.

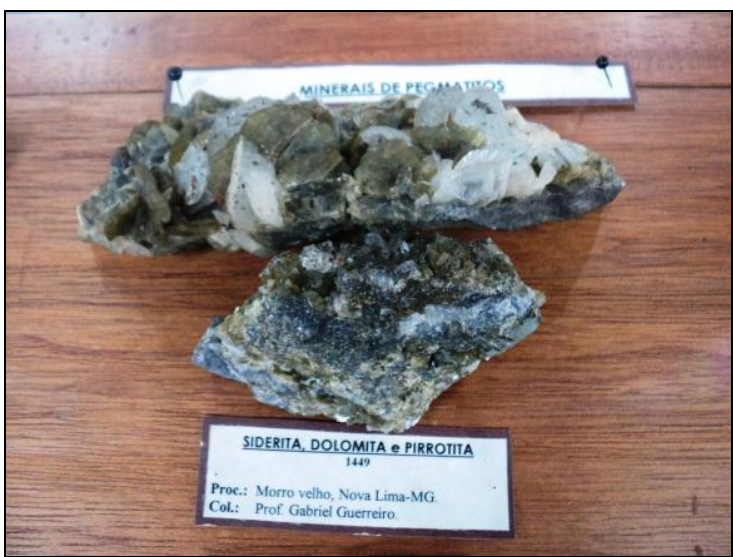

Figura 70: Siderita, Dolomita e Pirrotita do Museu de Geociências da UFPA.

Autor da foto: Luciana Florenzano, 2011. 


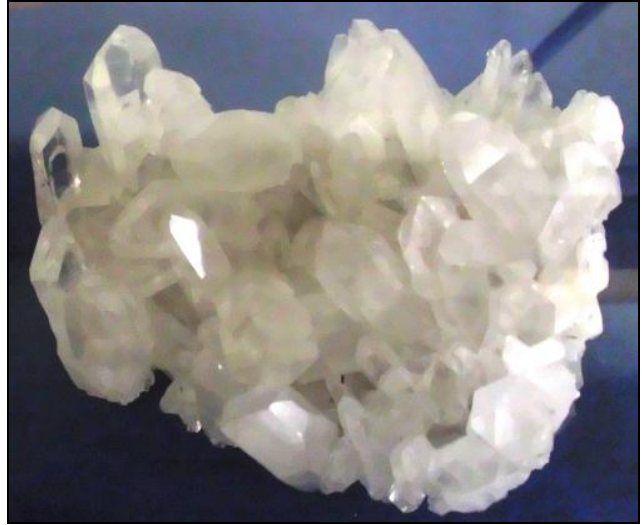

Figura 71: Quartzo do Museu de Geociências da UFPA.

Autor da foto: Luciana Florenzano, 2011.

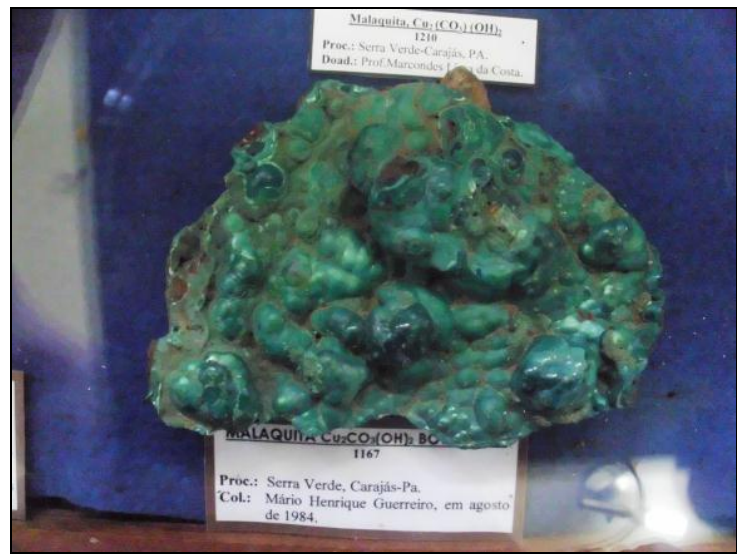

Figura 73: Malaquita do Museu de Geociências da UFPA.

Autor da foto: Luciana Florenzano, 2011.

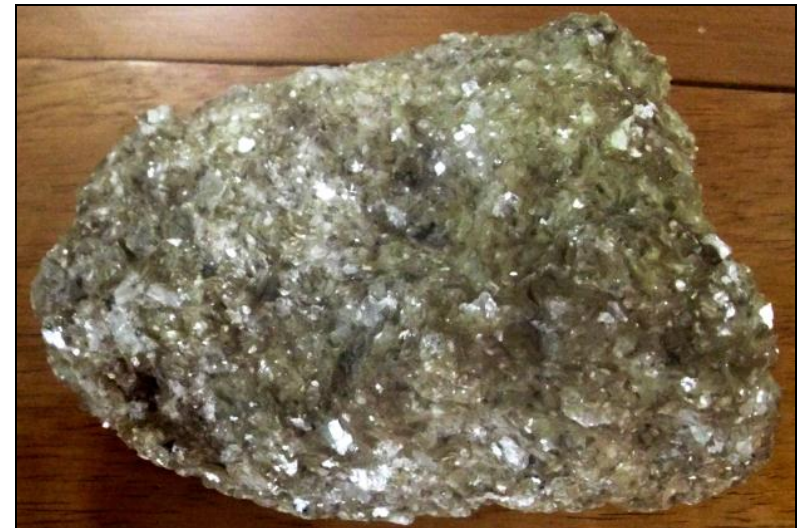

Figura 72: Zinnwaldita do Museu de Geociências da UFPA.

Autor da foto: Luciana Florenzano, 2011.

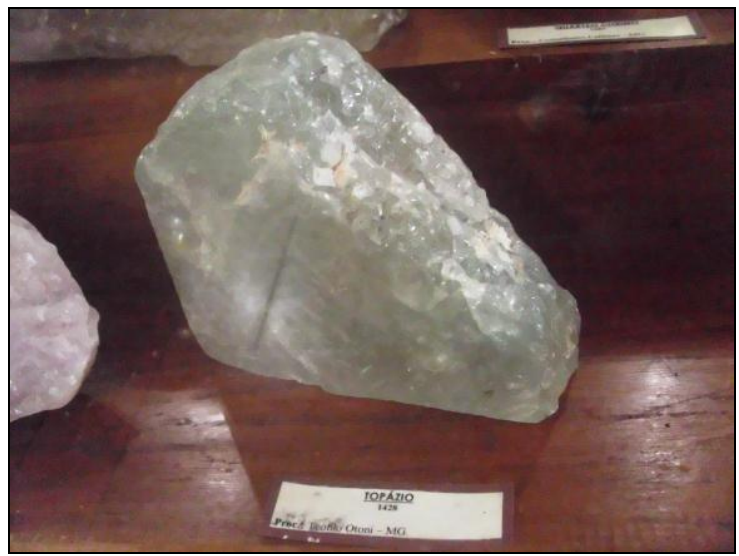

Figura 74: Topázio do Museu de Geociências da UFPA.

Autor da foto: Luciana Florenzano, 2011.

Classes química-cristaloquímica dos minerais: dos elementos nativos aos silicatos.

- Os principais Grupos de Rochas: Ígneas, Sedimentares e Metamórficas². (Figura 75, 76, 77, e 78).

\footnotetext{
${ }^{2}$ Podemos dividir as rochas em três grandes grupos, de acordo com a sua origem: sedimentares, metamórficas, e Ignéas. As sedimentares originam-se na superfície por ação dos fenômenos geológicos externos. As metamórficas resultam da transformação de rochas preexistentes por ação da pressão e da temperatura em profundidades. Finalmente, as Ignéas ou vulcânicas são o resultado da cristalização de massas fundidas e magnas que, originando-se do interior da crosta, foram expelidas por processos vulcânicos. (ALTABA, MIGUEL,1975, P. 27)
} 


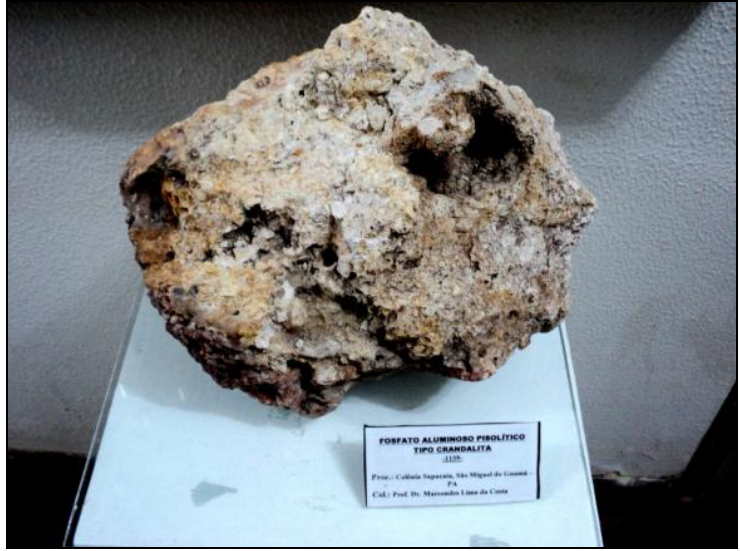

Figura 75: Fosfato aluminoso pisolítico tipo crandalita, do Museu de Geociências da UFPA

Autor da foto: Luciana Florenzano, 2011.

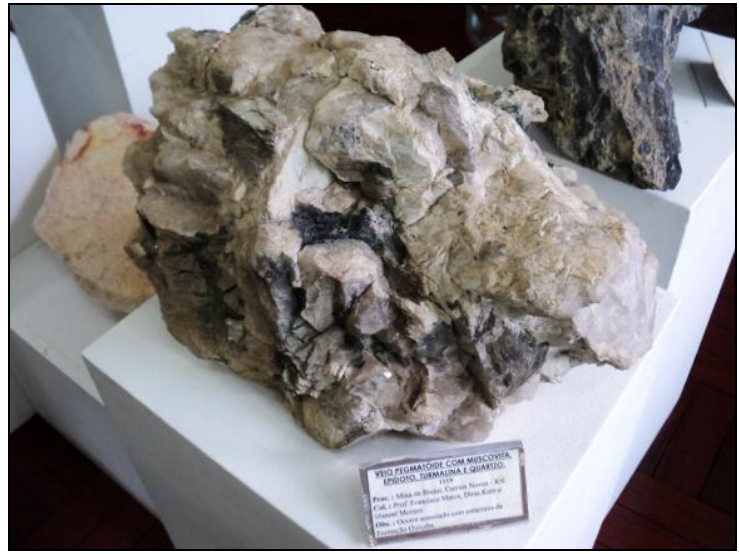

Figura 76: Veio Pegmatóide com Muscovita, Epidoto, Turmalina e Quartzo, do Museu de Geociências da UFPA.

Autor da foto: Luciana Florenzano, 2011.

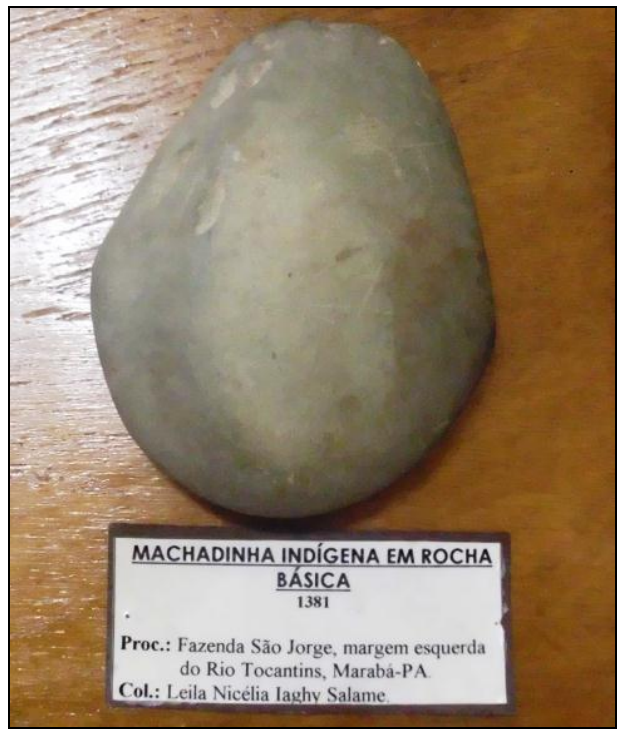

Figura 77: Machadinha Índigena em rocha básica, acervo do Museu de Geociências da UFPA.

Autor da foto: Luciana Florenzano, 2011.

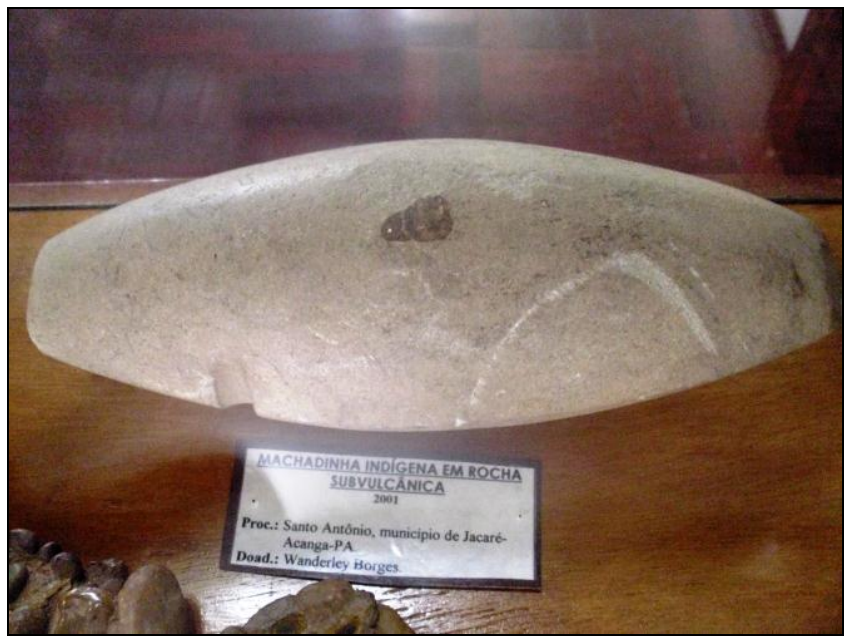

Figura 78: Machadinha Índigena em rocha subvulcânica, acervo do Museu de Geociências da UFPA. Autor da foto: Luciana Florenzano, 2011.

- Rochas do Arquipélago de Fernando de Noronha.

E uma extensa variedade de fosséis:

- Fauna da formação Pirabas, Mioceno inferior da região nordeste do Pará. Organizado pela professora Jane Garrafielo Fernandes (Figura 79 e 80). 


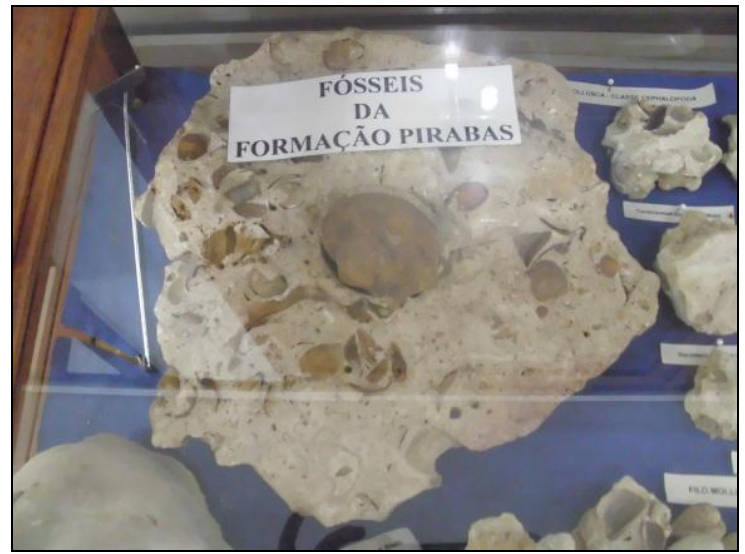

Figura 79: Fosséis da Formação Pirabas, acervo do Museu de Geociências da UFPA. Autor da foto: Luciana Florenzano, 2011.

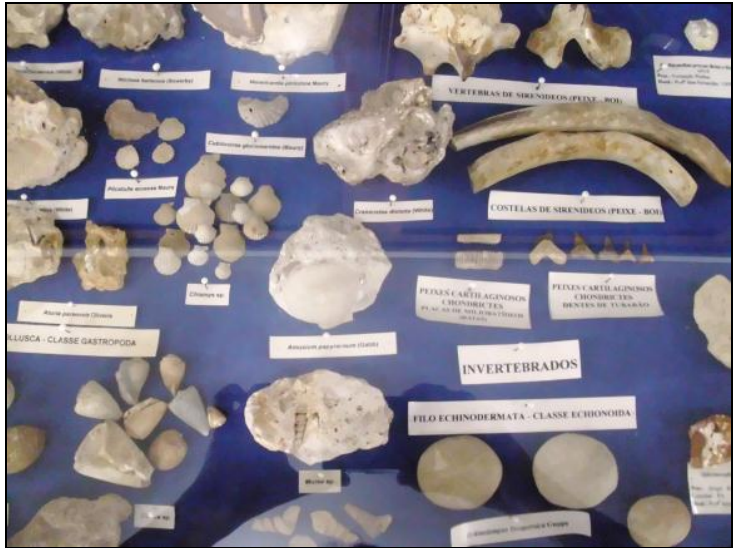

Figura 80: Fosséis da Formação Pirabas, acervo do Museu de Geociências da UFPA. Autor da foto: Luciana Florenzano, 2011.

- Fósseis da bacia do Paraná (Figura 81 e 82).

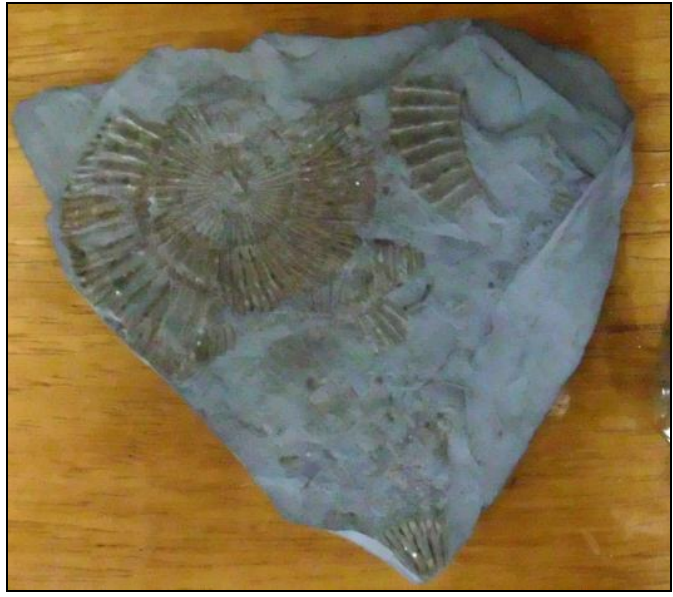

Figura 81: Fosséis da bacia do Paraná, acervo do Museu de Geociências da UFPA. Autor da foto: Luciana Florenzano, 2011.

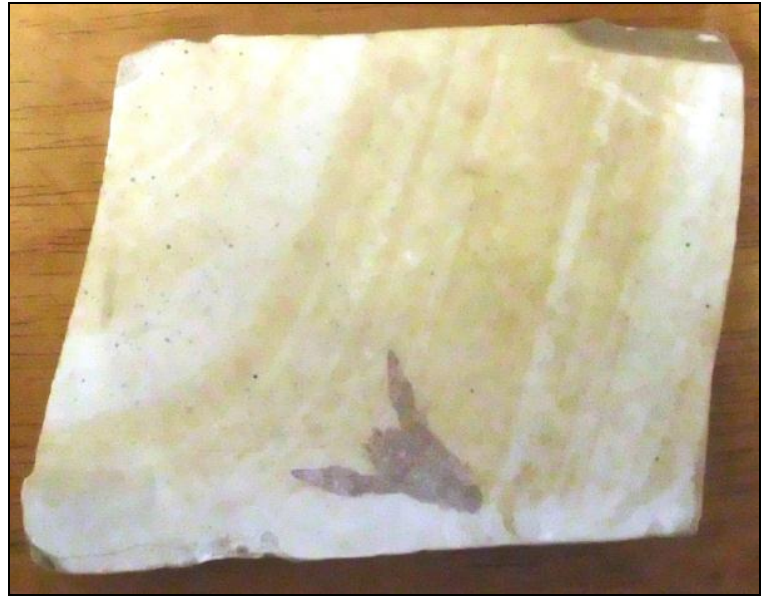

Figura 82: Fosséis da bacia do Paraná, acervo do Museu de Geociências da UFPA. Autor da foto: Luciana Florenzano, 2011.

- Miscelânea Paleontológica, com diversos exemplos de fósseis da mais variada procedência. Organização da professora Jane Garrafielo Fernandes (Figuras 83 e 84). 


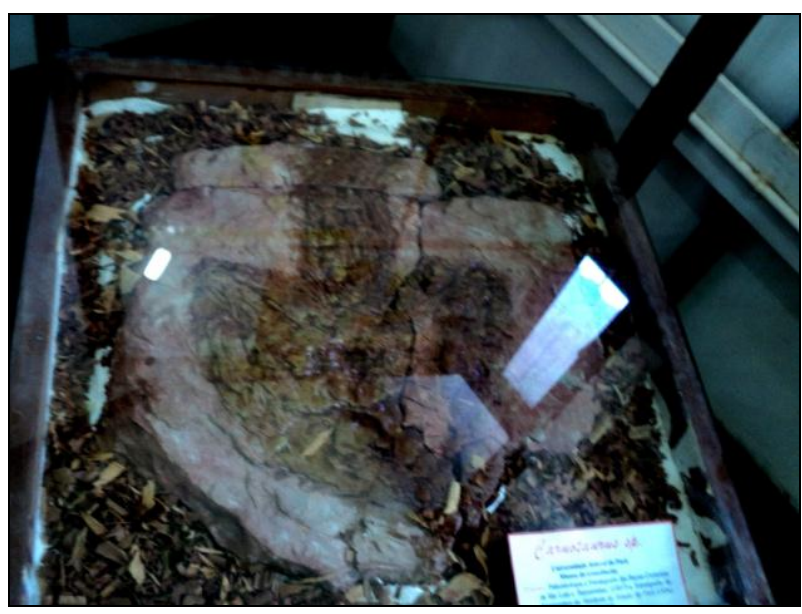

Figura 83: Pegada do Carnotaurus sp, acervo do Museu de Geociências da UFPA.

Autor da foto: Luciana Florenzano, 2011.

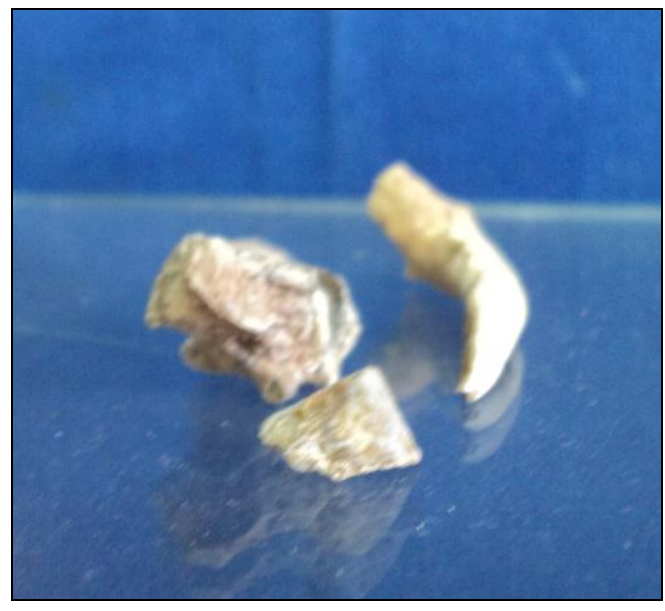

Figura 84: Dentes de F.C Purussaurus (crodilídeos), acervo do Museu de Geociências da UFPA.

Autor da foto: Luciana Florenzano, 2011.

\subsubsection{EXPOSIÇÃO TEMPORÁRIA}

A atual exposição temporária do museu é composta por:

- Minerais da mina de estanho e prata de Potosi e Oruro, Bolívia. Doação da universidade Autônoma "Tomás Frias", de Potosi, Bolívia (Figura 85).

- Coisas do Acre. Organização de Walmeire Alves de Melo Costa.

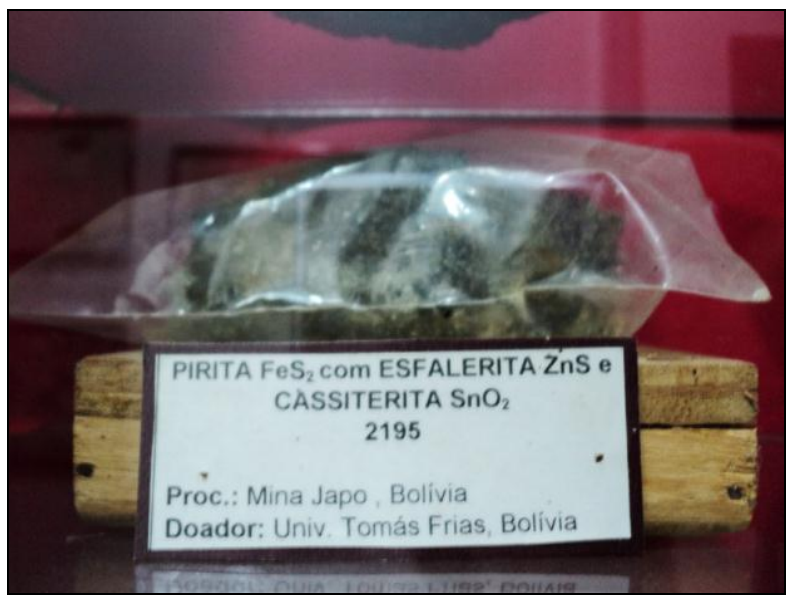

Figura 85: Pirita com Esfarelita e Cassiterita, acervo do Museu de Geociências da UFPA. Autor da foto: Luciana Florenzano, 2011. 
Além das duas exposições, o museu também possui uma secção destinada às gemas e artesanato (Figuras 86 e 87):

- Minerais de gemas.

- Bio-jóias.

- Artesanato e bio-jóias em Jarina.

- Artesanato em cloritito

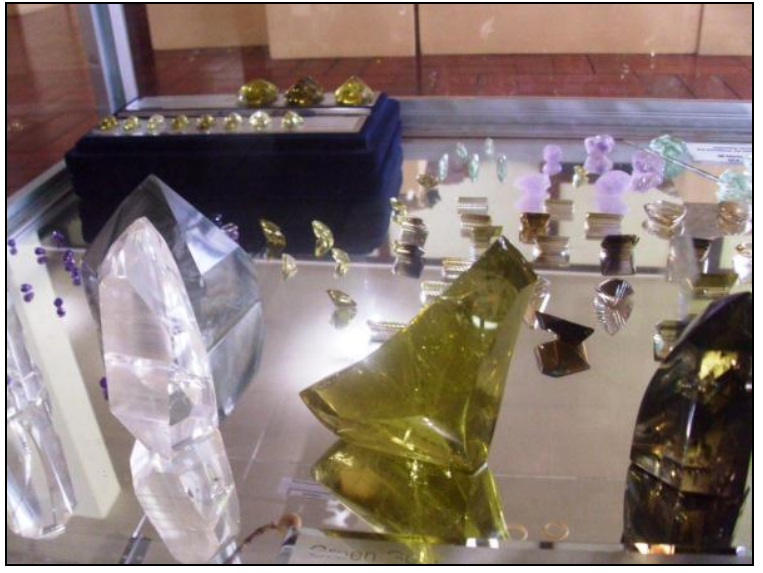

Figura 86: Minerais de gemas, acervo do Museu de Geociências da UFPA.

Autor da foto: Luciana Florenzano, 2011.

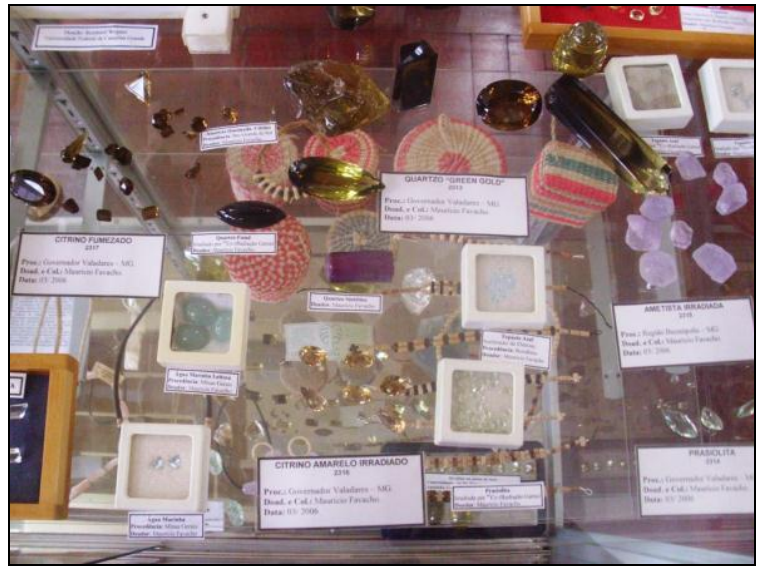

Figura 87: Minerais de gemas, acervo do Museu de Geociências da UFPA.

Autor da foto: Luciana Florenzano, 2011.

Conhecendo o acervo, representado neste trabalho por meio de alguns exemplares, e em consequência sua dimensão e importância, torna-se visível a necessidade de organizá-lo em um espaço físico que o exalte e que seja um atrativo para o Instituto de Geociências.

A coleção associada às constantes pesquisas e atividades desenvolvidas pelo Grupo de Mineralogia e Geoquímica Aplicada (GMGA), torna o Museu de Geociências uma instituição com alto potencial atrativo, com a possibilidade de expandir o acervo, trazendo benefícios tanto para Universidade, com a procura maior dos universitários e de alunos interessados em estudar Geociências, quanto para cidade de Belém, com a troca de informações de pesquisadores provenientes de outros estados e países, interessados no intercâmbio de conhecimento com a instituição. 


\section{PROPOSTA ARQUITETÔNICA PARA O MUSEU DE HISTÓRIA GEOLÓGICA DA AMAZÔNIA}

\subsection{ESTUDOS PRÉ-PROJETUAIS}

\subsubsection{LOCAL DE IMPLANTAÇÃO}

A área escolhida para a implantação do projeto arquitetônico está situada dentro do campus da Universidade Federal do Pará e trata-se um terreno vazio, situado no parque geocientífico (Figura 88 e 89), em frente à biblioteca setorial do Instituto de Geociências. Como a proposta está contida nos limites da cidade universitária, os parâmetros legais foram ditados pelo Plano Diretor Urbanístico da Cidade Universitária José da Silveira Netto.

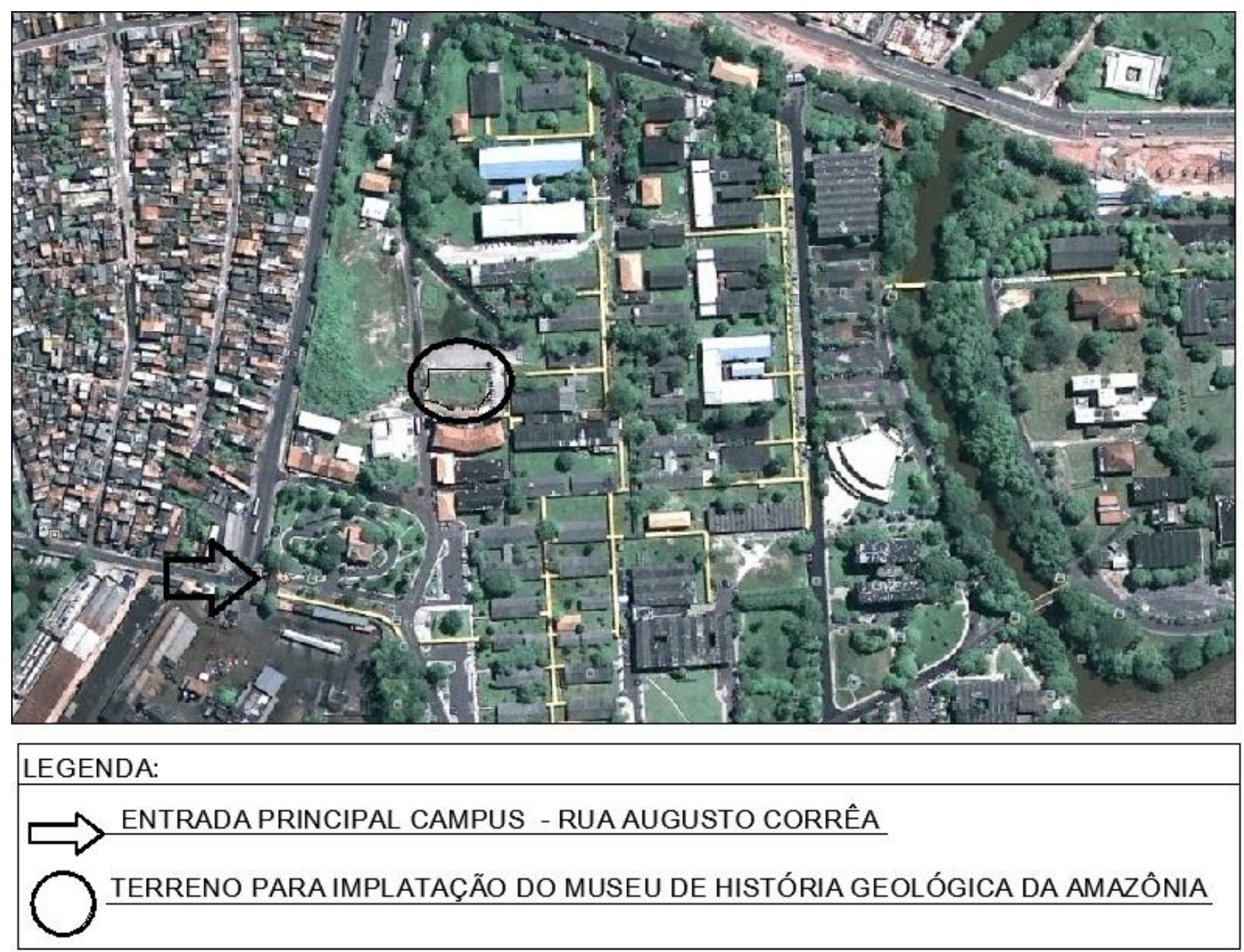

Figura 88: Terreno para implantação do Museu de História Geológica da Amazônia. Fonte: Google Earth. 


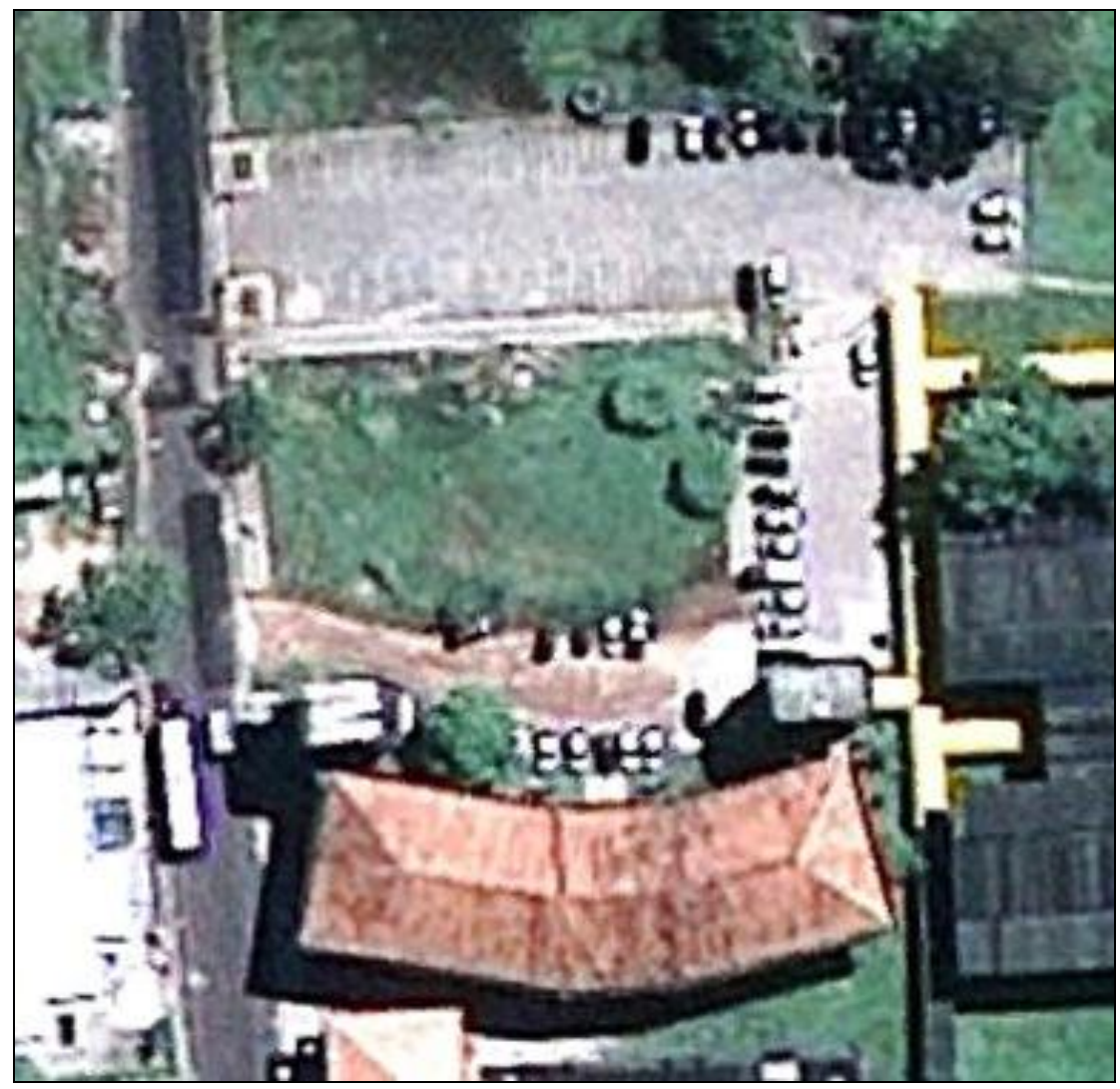

Figura 89: Terreno para implantação do Museu de História Geológica da Amazônia.

Fonte: Google Earth.

De acordo com o Plano Diretor, o terreno escolhido para implantação deste trabalho está inserido no Setor Básico do campus, e mais especificadamente na quadra 01 do setor, conforme o anexo A. A escolha do terreno implica no cumprimento do Plano Diretor Urbanístico da cidade universitária. Logo, o presente trabalhou procurou enquadrar-se nas condições estabelecidas pelo terreno.

Sendo assim, de acordo com o anexo B, para o Setor Básico, o qual conta com 30,33 de área são permitidos os seguintes índices urbanísticos:

- Taxa de ocupação máxima do setor de $40 \%$;

- Coeficiente de aproveitamento máximo de 0,8;

- Afastamento mínimo pelas edificações por quadra;

- Quadra 01 e 04 - 10 m; 
O Plano Diretor da Universidade possui os índices urbanísticos por setores e quadras. Desse modo, o projeto aqui proposto preocupou-se em manter a distância entre outras edificações de $10 \mathrm{~m}$. A taxa de ocupação utilizada foi a de $64.7 \%$. A altura total da construção é de $13 \mathrm{~m}$. Tal utilização do solo e coeficiente de aproveitamento máximo foram permitidos, uma vez que a quadra 01 do Setor básico não possui grandes áreas adensadas, como visualizado nas imagens mostradas. Portanto, a taxa de ocupação utilizada, de $64.7 \%$ irá contribuir para o adensamento do setor, sem fugir dos parâmetros legais exigidos pelo Plano diretor.

Em relação ao zoneamento do uso do solo, a edificação classifica-se no uso Institucional, com atividades administrativas e uso público em geral.

Como já existe em frente ao terreno escolhido para implantação, um estacionamento já consolidado, a proposta fez pequenas modificações no mesmo, para melhor acesso ao museu, e visando contemplar vagas para portadores de necessidade especiais.

\subsubsection{PROGRAMA DE NECESSIDADES}

A definição do programa de necessidades percorreu um longo caminho, iniciado pelo estudo dos museus, partindo da sua essência, atravessando diversos períodos até atingir sua função dentro do atual contexto. Foram estudados casos internacionais, nacionais e regionais, através da extensa pesquisa realizada, a qual atingiu quase que na totalidade todas as instituições museais da cidade de Belém.

Por fim, foi realizada uma profunda investigação sobre a história do Museu de Geociências da UFPa, assim como a compreensão sobre seu acervo, e os anseios e necessidades dos seus usuários.

Estas etapas serviram de base para a materialização dos conceitos e diretrizes museológicas na determinação do programa de necessidades e consequente organograma. De forma a aplicar a museologia na arquitetura e desta relação se extrair algo funcional e harmônico.

Desse modo, em um primeiro momento foram estabelecidas as duas principais funções da instituição, aqui definidas como a função de salvaguarda e a função de comunicação. Em seguida, foram determinados todos os setores necessários ao funcionamento do museu. 
Portanto, o espaço físico do edifício foi conduzido através da integração de seis setores, sendo eles:

TABELA 1: DIVISÃO SETORES.

\section{SETOR 01: SETOR DE COMUNICAÇÃO, EXPOSIÇÕES E EDUCAÇÃO}

Setor destinado às atividades referentes aos diversos níveis comunicação, tanto do acervo com o visitante, através da exposição permanente e da temporária, quanto do edifício com os usuários.

\section{SETOR 02: SETOR DE SALVAGUARDA}

Setor destinado à salvaguarda da coleção do museu, através do seu correto acondicionamento.

\section{SETOR 03: SETOR DE PESQUISA}

Setor responsável por manter as constantes pesquisas na área das Geociências realizadas pelo Instituto de Geociências.

SETOR 04: SETOR ADMINISTRATIVO

Setor do museu destinado a atender a organização administrativa da instituição.

SETOR 05: SETOR DE SERVIÇOS GERAIS

Setor destinado a atender as manutenções necessárias ao edifício, assim como os espaços necessários ao convívio e acomodação dos funcionários.

SETOR 06: SETOR DE APOIO AO VISITANTE

Setor de suporte as atividades desenvolvidas pelo visitante dentro do museu.

Com a definição dos setores foi possível determinar e dimensionar os ambientes necessários para atender corretamente os diversos setores do museu, ilustrados na tabela 2:

TABELA 2: DIVISÃO SETORES.

\begin{tabular}{|c|l|c|}
\hline \multicolumn{3}{|c|}{ PROGRAMA DE NECESSIDADES } \\
MUSEU DE HISTÓRIA GEOLÓGICA DA AMAZÔNIA \\
\hline \multirow{2}{*}{ SETOR } & \multicolumn{1}{|c|}{ AMBIENTE } & $\begin{array}{l}\text { ÁREA } \\
\left(\mathrm{m}^{2}\right)\end{array}$ \\
\hline \multirow{3}{*}{ SETOR SALVAGUARDA } & 1. Laboratório de Conservação de Acervo & 20,00 \\
\cline { 2 - 3 } & 2. Documentação Museológica & 12,00 \\
\cline { 2 - 3 } & 3. Higienização da Coleção & 12,00 \\
\hline
\end{tabular}




\begin{tabular}{|c|c|c|}
\hline & 4.Guarda temporária & 10,00 \\
\hline & 5. Reserva Técnica & 90,00 \\
\hline & TOTAL & 144,00 \\
\hline \multirow{5}{*}{ SETOR DE PESQUISA } & 6. Laboratório básico de caracterização mineral & 25,00 \\
\hline & 7. Pesquisas I & 20,00 \\
\hline & 8. Pesquisas II & 20,00 \\
\hline & 9. Alojamento pesquisador visitante I e II & 50,00 \\
\hline & TOTAL & 115,00 \\
\hline \multirow{3}{*}{$\begin{array}{l}\text { SETOR DE COMUNICAÇÃO } \\
\text { - EXPOSIÇÕES }\end{array}$} & 10. Exposição Permanente & 300,00 \\
\hline & 11. Exposição Temporária & 200,00 \\
\hline & 12. Equipamentos expográficos & 15,00 \\
\hline \multirow{4}{*}{$\begin{array}{l}\text { SETOR DE COMUNICAÇÃO } \\
\text { - EDUCAÇAO }\end{array}$} & 13. Sala multimídia & 15,00 \\
\hline & 14. Auditório (90 lugares) & 110,00 \\
\hline & 15. Mini-biblioteca & 25,00 \\
\hline & TOTAL & 665,00 \\
\hline \multirow{5}{*}{ SETOR ADMINISTRATIVO } & 16. Diretoria & 15,00 \\
\hline & 17. Secretaria & 5,00 \\
\hline & 18. Educação & 10,00 \\
\hline & 19. Montagem Exposições & 15,00 \\
\hline & TOTAL & 45,00 \\
\hline \multirow{5}{*}{$\begin{array}{l}\text { SETOR DE SERVIÇOS } \\
\text { GERAIS }\end{array}$} & 20. Sanitários vestiários funcionários & 40,00 \\
\hline & 21. Copa & 10,00 \\
\hline & 22. DML & 4,00 \\
\hline & 23. Lixeira & 4,00 \\
\hline & TOTAL & 58,00 \\
\hline \multirow{5}{*}{$\begin{array}{l}\text { SETOR DE APOIO AO } \\
\text { VISITANTE }\end{array}$} & 24. Hall de entrada & 60,00 \\
\hline & 25. Banheiros públicos & 30,00 \\
\hline & 26. Cafeteria & 30,00 \\
\hline & 27. Loja & 18,00 \\
\hline & TOTAL & 138,00 \\
\hline TOTAL GERAL SETORES & \multicolumn{2}{|l|}{$1.165,00$} \\
\hline ALVENARIA & \multicolumn{2}{|l|}{139,80} \\
\hline CIRCULAÇÕES (30\%) & \multicolumn{2}{|l|}{349,5} \\
\hline $\begin{array}{l}\text { TOTAL ÁREA } \\
\text { CONSTRUÍDA }\end{array}$ & \multicolumn{2}{|l|}{$1.654,30$} \\
\hline
\end{tabular}

\subsubsection{ORGANOGRAMA}

Por meio dessa definição, estudaram-se os diferentes fluxos e acessos que o edifício deveria conter. Dessa forma, a proposta arquitetônica obedeceu ao seguinte organograma: 


\section{ORGANOGRAMA MUSEU DE HISTÓRIA GEOLÓGICA DA AMAZÔNIA}

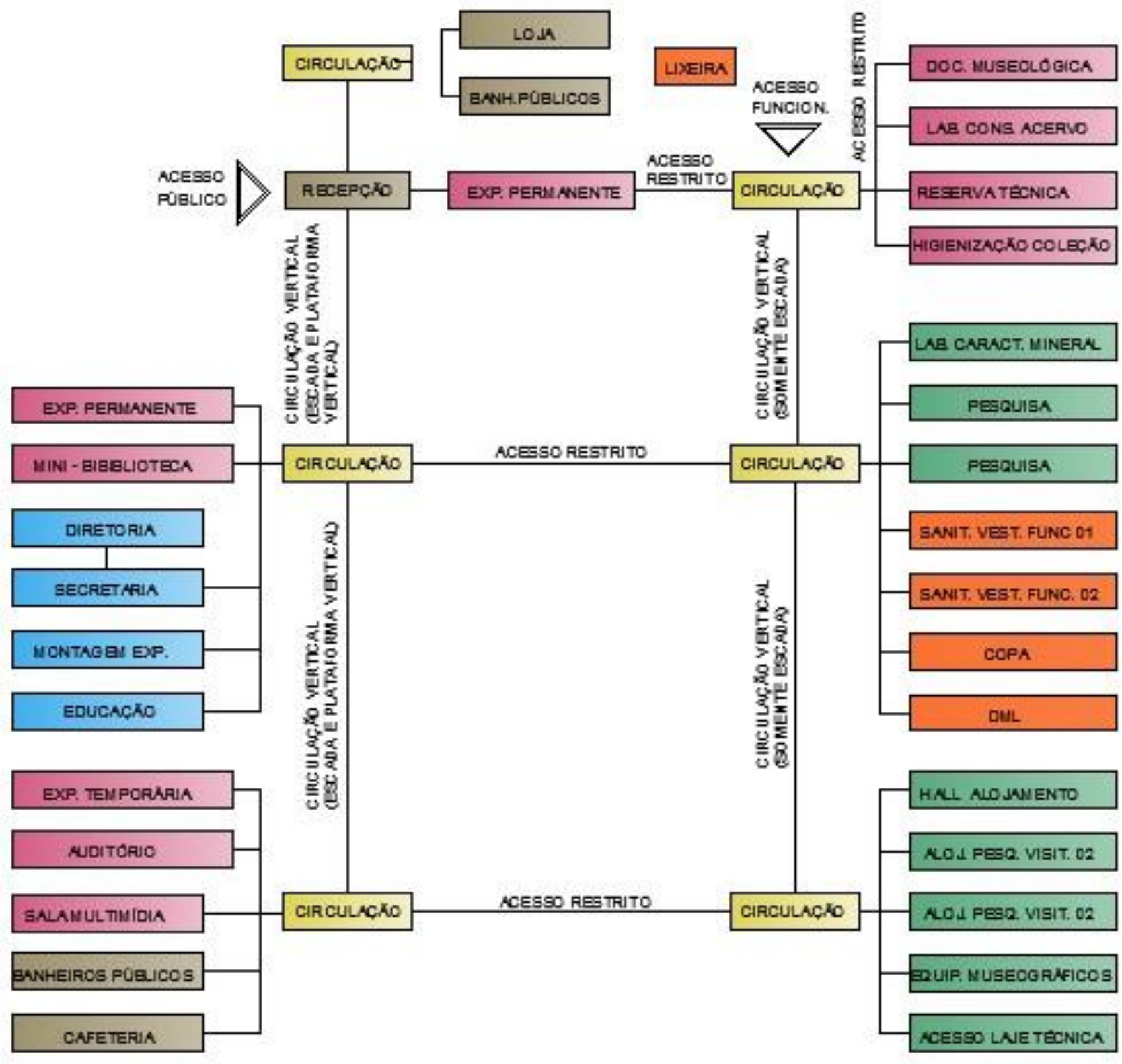

Figura 90: Organograma. 


\subsubsection{SETORIZAÇÃO}

Para um projeto arquitetônico voltado às instituições museais, as áreas dos setores definidos devem refletir as atividades desenvolvidas pelo museu. O setor de educação compreende as exposições permanentes e temporárias, assim como as atividades relacionadas à educação do público. É, portanto, o setor com mais espaços dentro da instituição. Após ele, destaca-se a necessidade de áreas estratégicas para o setor de salvaguarda, por se tratar do conjunto de ambientes destinados à conservação da coleção.

Portanto, após a compreensão do tipo de acervo e suas condições corretas de armazenamento e exposição, associado ao local de implantação, a orientação solar, e ao universo do museu de geociências, desenvolveu-se a setorização e organização dos ambientes, dispostos da seguinte maneira (Figura 91, 92 e 93):

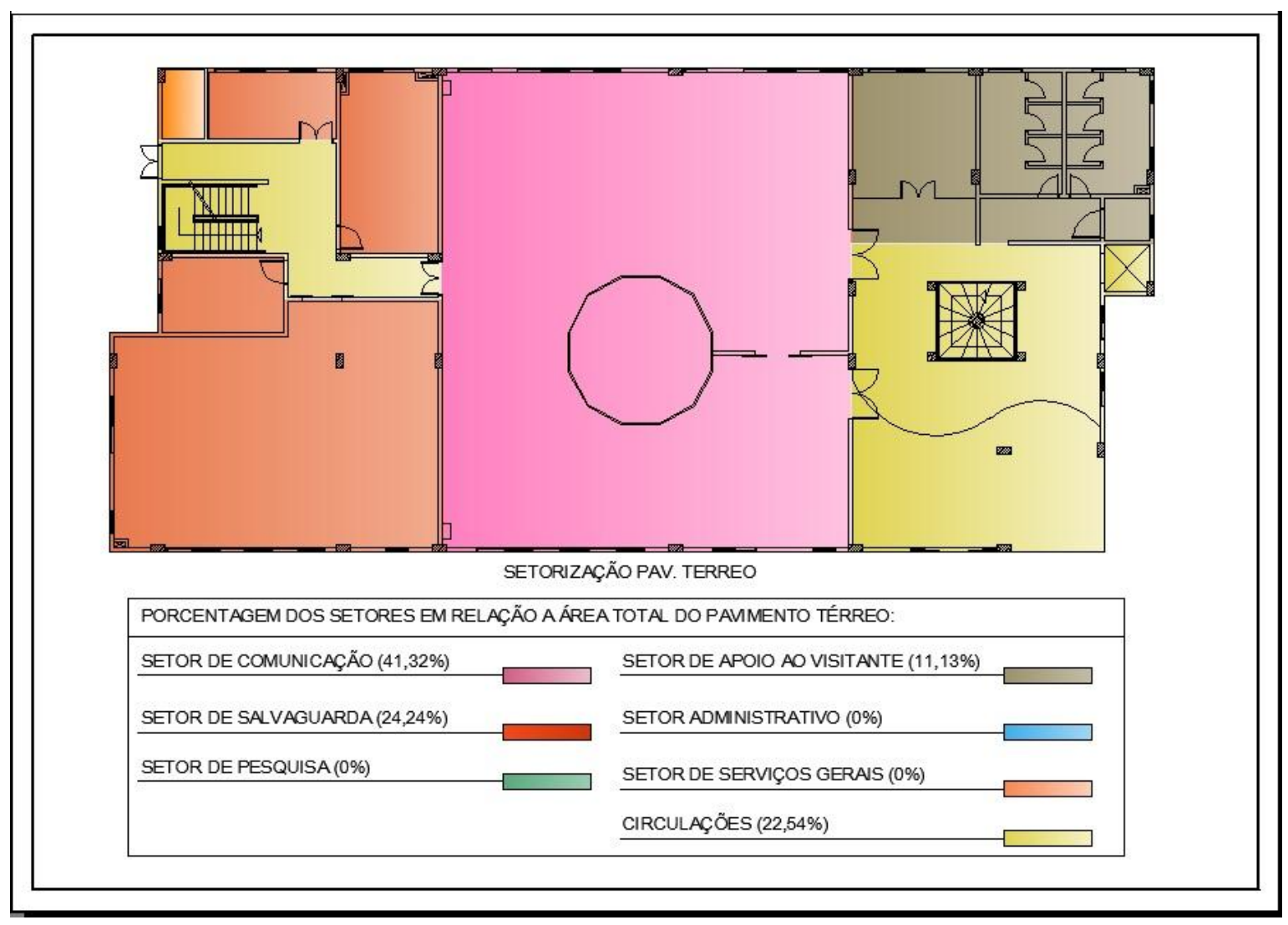

Figura 91: Setorização do pavimento térreo. 


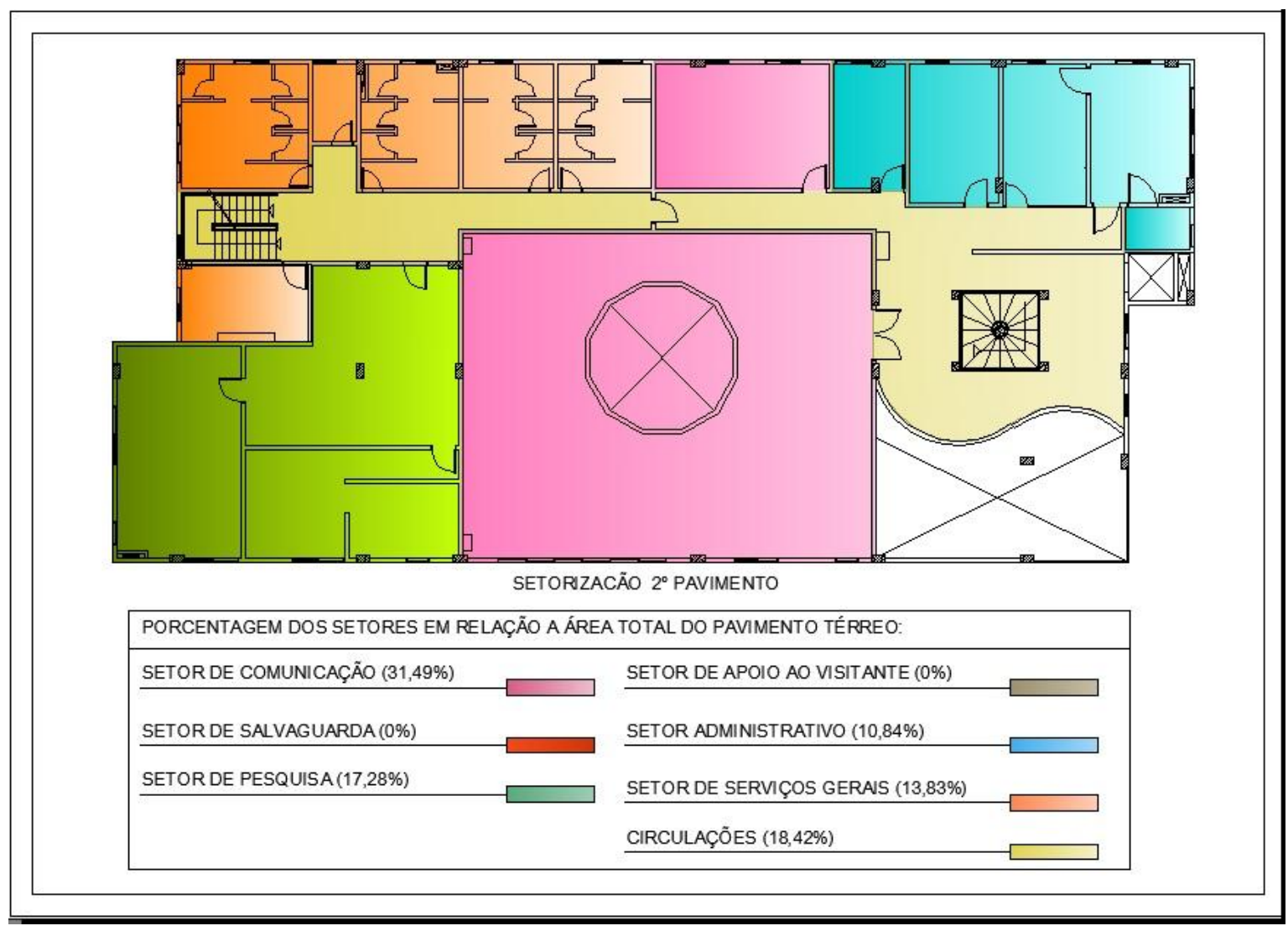

Figura 92: Setorizacão do $2^{\circ}$ pavimento.

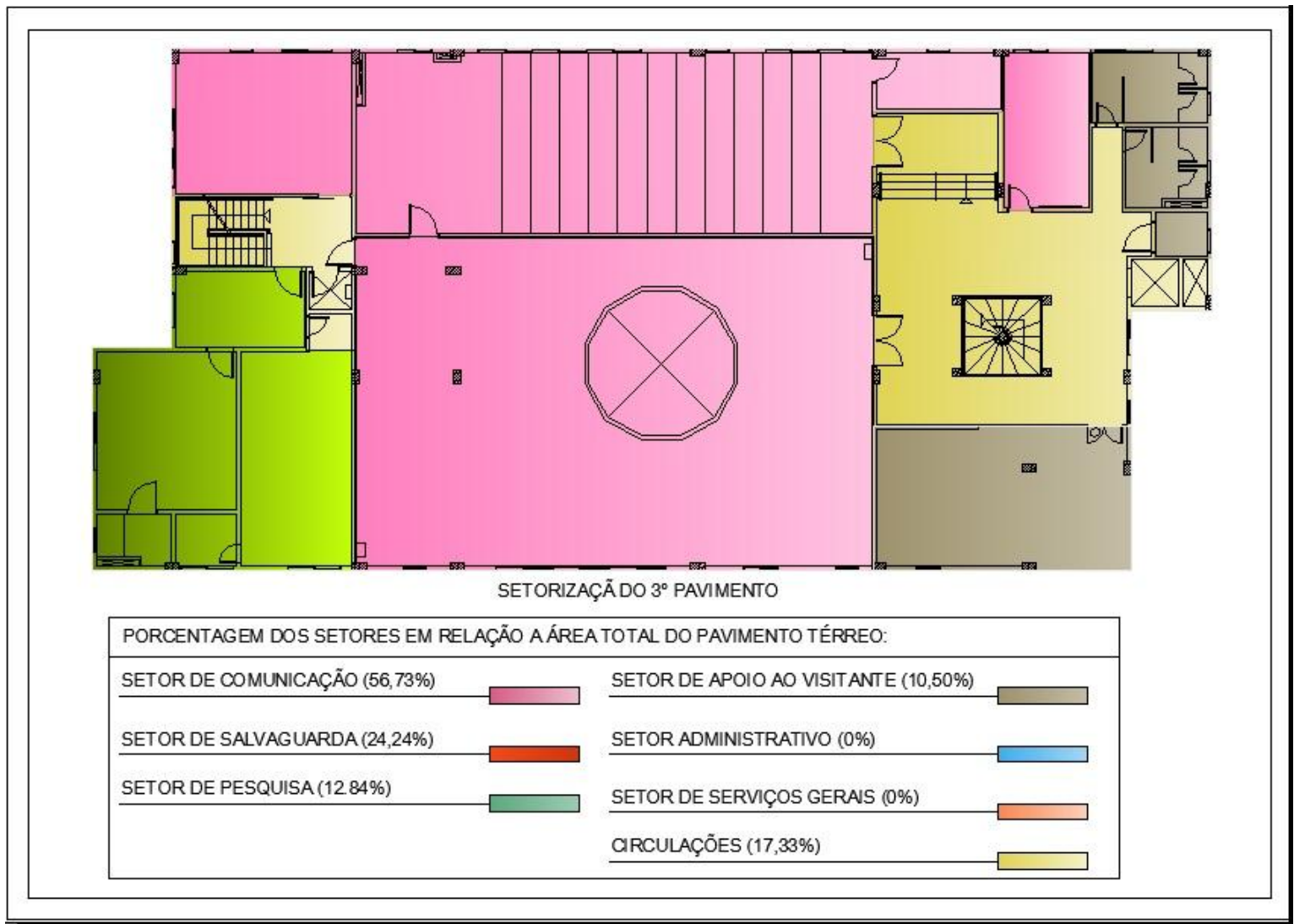

Figura 93: Setorização do $3^{\circ}$ pavimento. 


\section{PROJETO ARQUITETÔNICO}

\subsection{MEMORIAL JUSTIFICATIVO}

\subsubsection{CONCEITOS ADOTADOS}

A arquitetura é indubitavelmente, representada pela sua materialização no espaço. Logo, em uma primeira instância, o modo como ocorre essa materialização, torna-se, mesmo que esse não seja seu objetivo, o resultado final da arquitetura. Posteriormente ao objeto materializado e a consequente percepção humana sobre ele, a arquitetura incorpora outras funções e valores.

Sendo assim, o projeto arquitetônico aqui mostrado tem como objetivo apresentar uma proposta baseada em princípios fundamentais de composição, retornando a questão primária da arquitetura, de acordo com Ching (2005), uma combinação dos elementos geradores da forma, como linhas e pontos em um plano. Desse modo, os princípios norteadores do processo de elaboração da proposta arquitetônica para o Museu de História Geológica da Amazônia se baseiam nos conceitos de harmonia, ritmo, equilíbrio, proporção e contraste. Entretanto, outros fatores foram estudados e inseridos na elaboração formal.

O primeiro deles foi a localização do museu, dentro do Campus da cidade Universitária José da Silveira Netto. Como o terreno escolhido trata-se de uma área situada em um cruzamento de uma via com uma circulação interna do campus e um estacionamento já consolidado, o partido arquitetônico deveria causar impacto na lateral da via, por se tratar de um acesso mais utilizado dentro do campus (Figura 94).

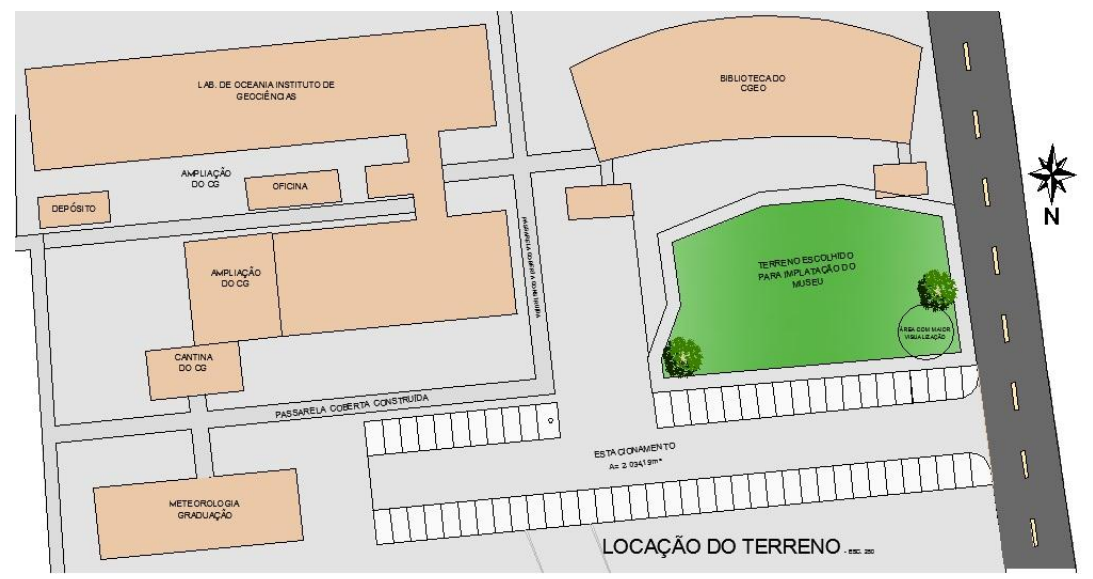

Figura 94. Localização do terreno na UFPa.

Fonte: Desenhos do autor. 
O segundo fator a ser considerado no desenvolvimento projetual refere-se à condição climática da cidade de Belém, com taxas elevadas de temperatura e umidade. Portanto, uma das medidas definidas antes mesmo da elaboração do projeto, era que este deveria, amenizar mesmo que em pequeno grau, o desconforto térmico decorrente dessas taxas.

\subsubsection{ELABORAÇÃO DO PARTIDO ARQUITETÔNICO}

Determinado o programa e consequentemente o espaço físico necessário, a representação do projeto deveria conter a essência do museu. Para tal, se partiu da decomposição de uma caixa de 35 metros de comprimento, por 13 metros de altura (Figura 95).

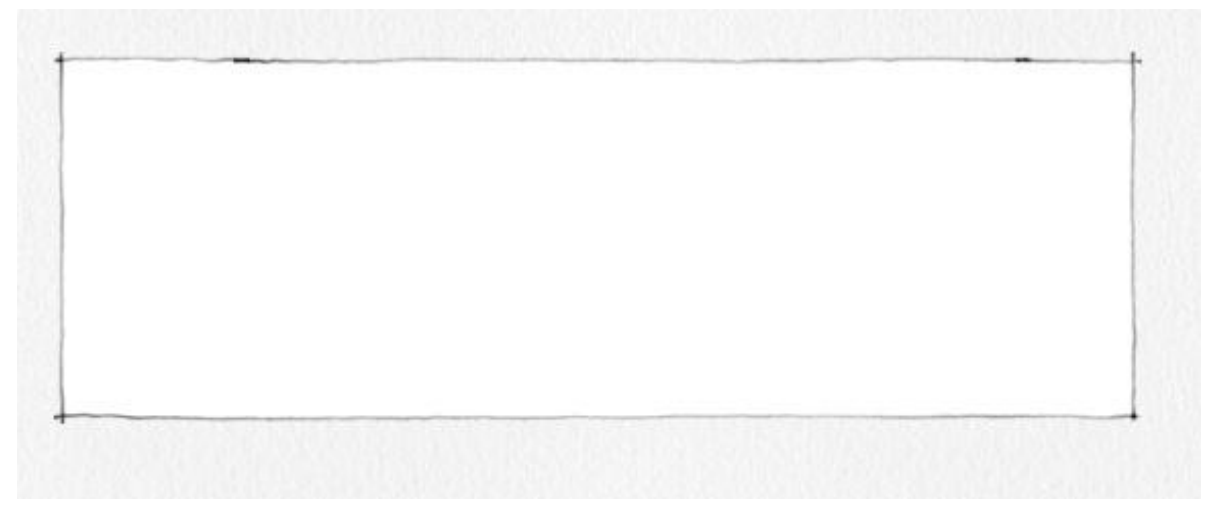

Figura 95: Etapa 01do desenvolvimento projetual.

Fonte: Desenhos do autor.

Em seguida, procurou-se estudar relações matemáticas de proporção e de decomposição dessa caixa (Figura 96).

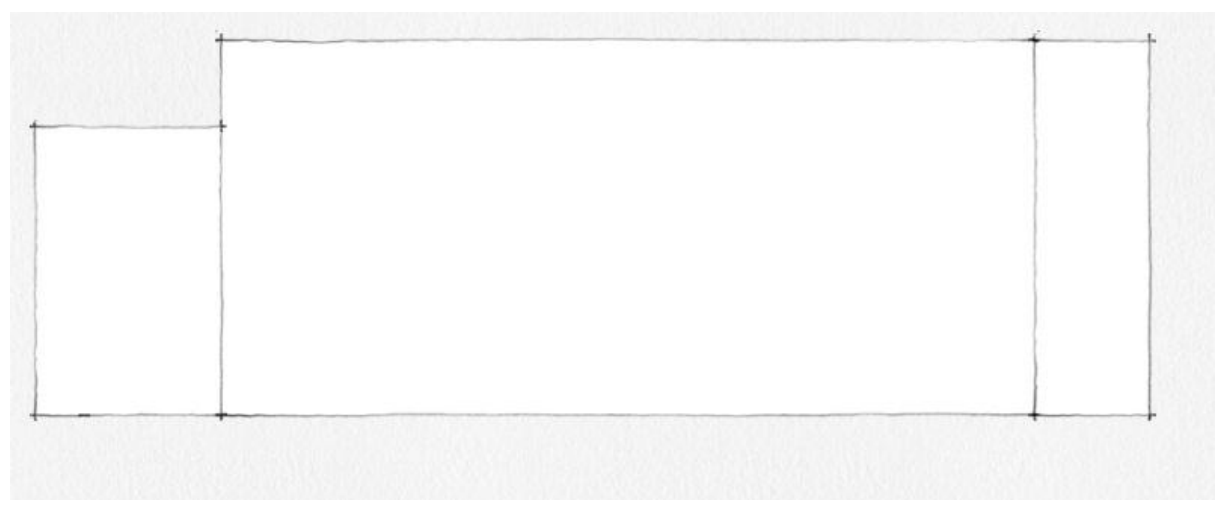

Figura 96: Etapa 02 do desenvolvimento projetual.

Fonte: Desenhos do autor.

Após isso, estudou-se o contraste e a relação de profundidade, através da inclinação de uma linha, aproximadamente $5^{\circ}$ para baixo do eixo (Figura 97). 


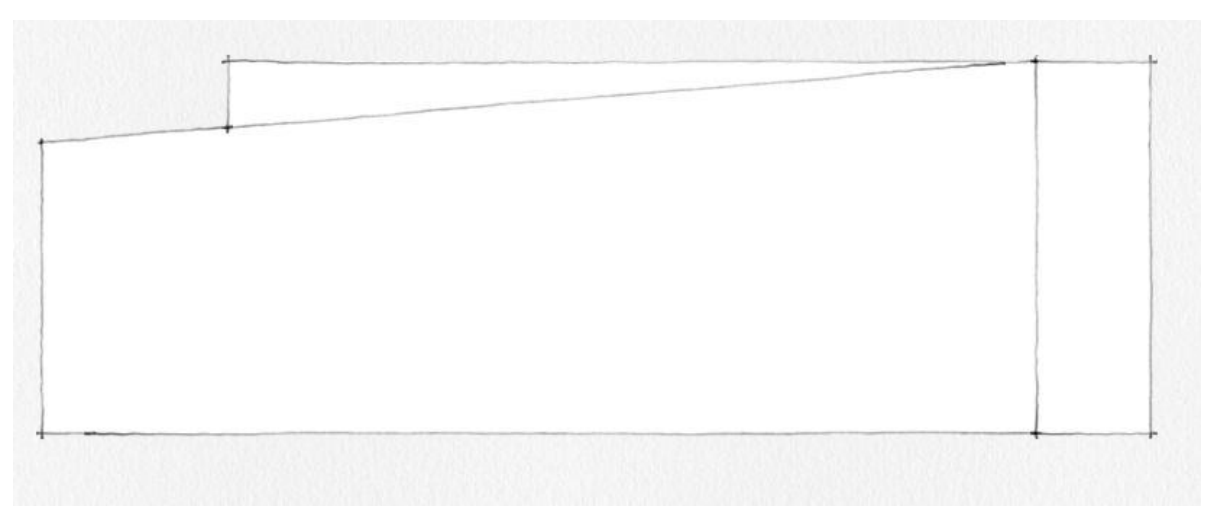

Figura 97: Etapa 03 do desenvolvimento projetual.

Fonte: Desenhos do autor.

Seguindo o conceito de contraste, e incorporando o conforto térmico como uma das premissas a serem seguidas, optou-se por inclinar $10^{\circ}$ algumas paredes, uma vez que realizando tal ato, diminui-se a incidência solar nos ambientes. Essa inclinação foi realizada a partir da linha à direita, posicionada à $90^{\circ}$ do eixo horizontal. Adotando essa linha como ponto de partida, as demais foram inclinadas em conjunto com a parede correspondente, de forma a compor o volume total, com uma linha reta e a sua paralela inclinada $10^{\circ}$ (Figura 98, 99 e 100).

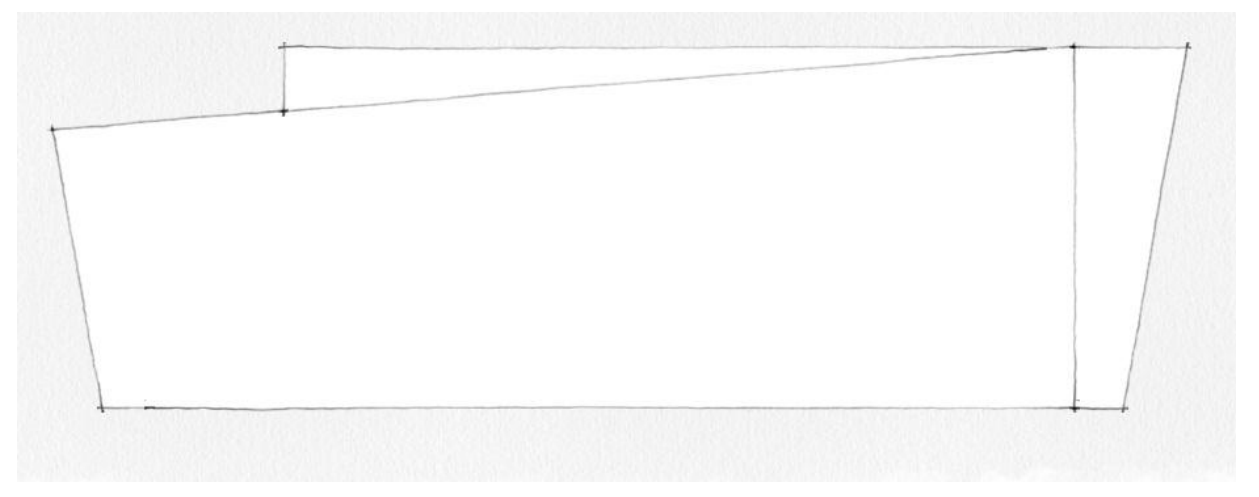

Figura 98: Etapa 04 do desenvolvimento projetual.

Fonte: Desenhos do autor. 


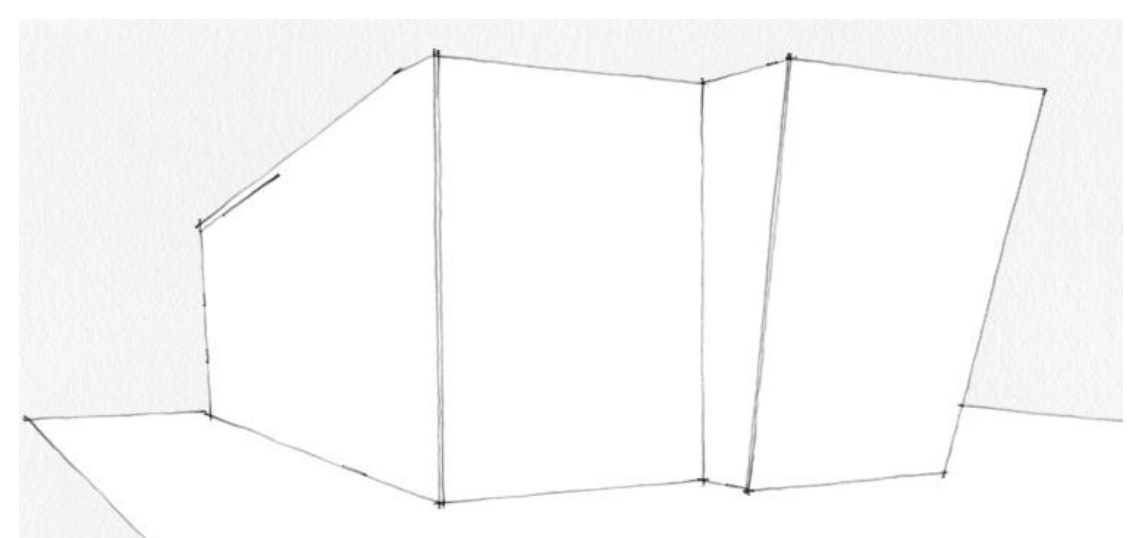

Figura 99: Etapa 04 do desenvolvimento projetual.

Fonte: Desenhos do autor.

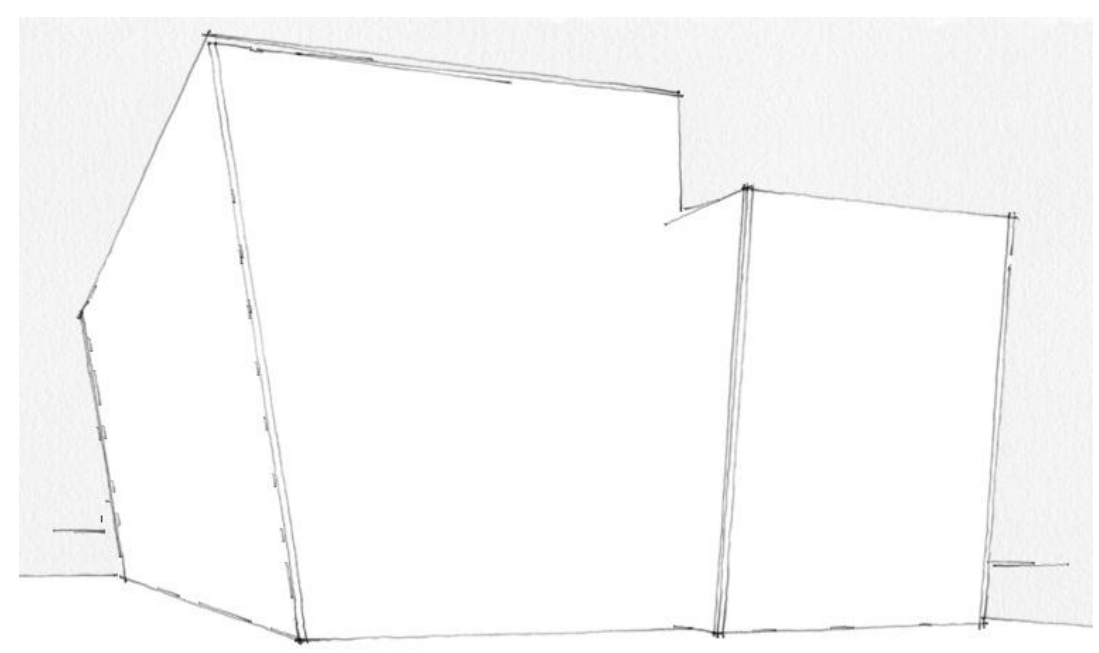

Figura 100: Etapa 04 do desenvolvimento projetual.

Fonte: Desenhos do autor.

Definindo o partido geral e suas dimensões, procurou-se dar continuidade a proposta voltada para uma tipologia de arquitetura mineral.

Para tal composição, o projeto buscou embasamento teórico nos polígonos ${ }^{3}$ e poliedros ${ }^{4}$. Inicialmente, o estudo se deu em relação ao triângulo, pelo fato desse polígono constituir um dos arranjos cristalográficos do mineral diamante (Figura 101 e 102).

\footnotetext{
${ }^{3}$ Figuras Planas limitadas por uma linha fechada.

${ }^{4}$ Sólidos geométricos constituídos por faces, que por sua vez são polígonos.
} 


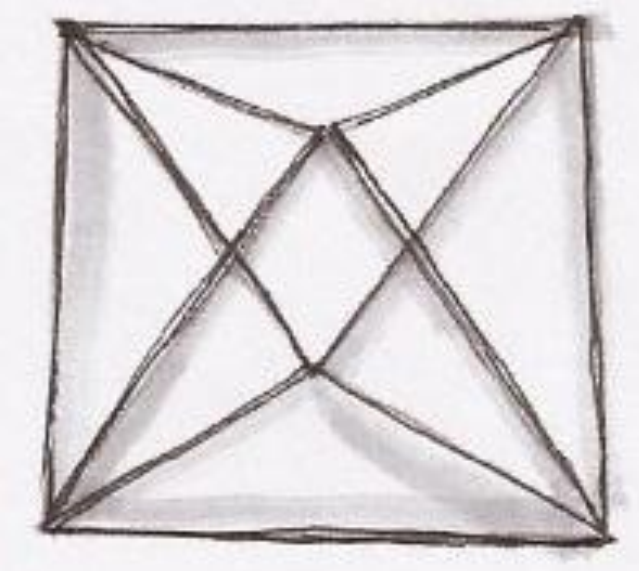

Figura 101: Croqui cristalização diamante. Fonte: Desenhos do autor.

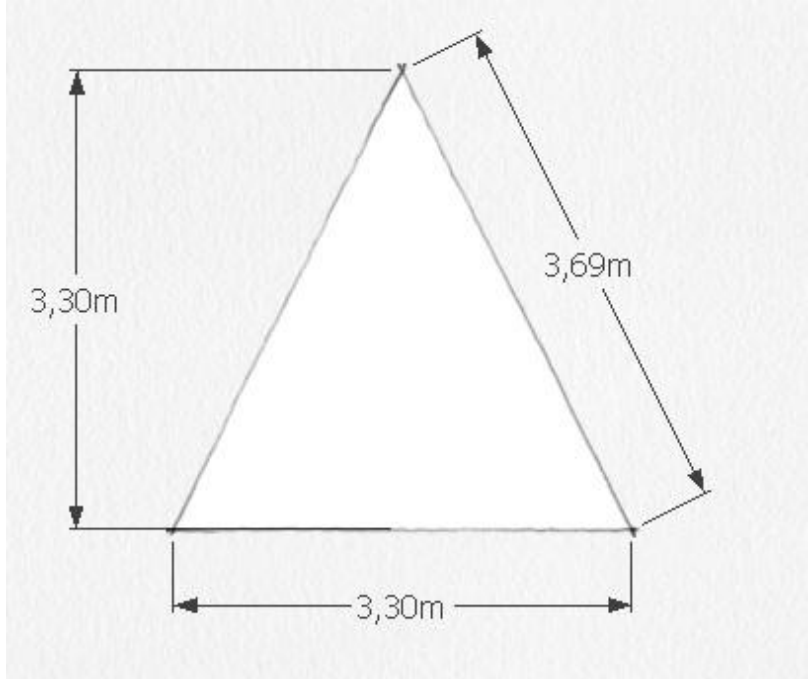

Figura 102: Croqui polígono triângulo. Fonte: Desenhos do autor.

Em seguida, foi definido, visando a integração e o contraste com o volume total da edificação, que o triângulo deveria ser constituído de uma estrutura transparente, por representar, dessa forma, a cristalinidade do diamante. Após essa definição, foi estudada a melhor forma de organização espacial, harmonia e proporcionalidade da estrutura cristalina com a dimensão da volumetria definida. Sendo assim, resolveu-se dispor do arranjo simétrico e vertical do triângulo (Figura 103 e 104), estabelecendo a altura máxima de 13.00 m já determinada pelo partido arquitetônico.

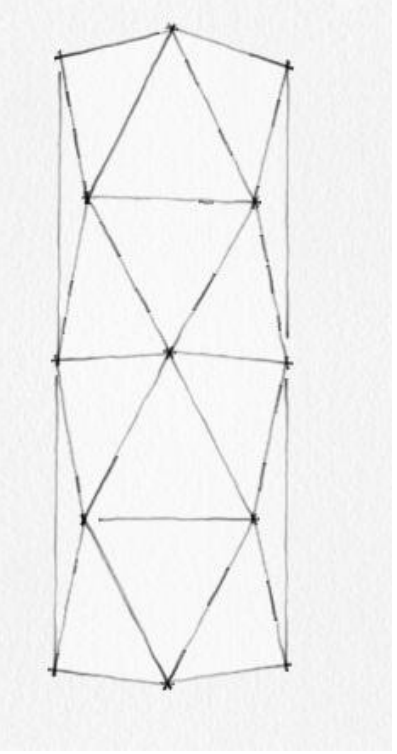

Figura 104: Croqui estrutura cristalina vertical. Vista Frontal.

Fonte: Desenhos do autor.

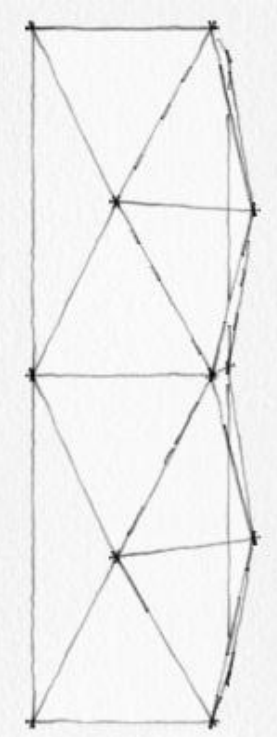

Figura 103: Croqui estrutura cristalina vertical. Vista Lateral. Fonte: Desenhos do autor. 
Com essa verticalização, chegou-se à seguinte integração (Figura 105):

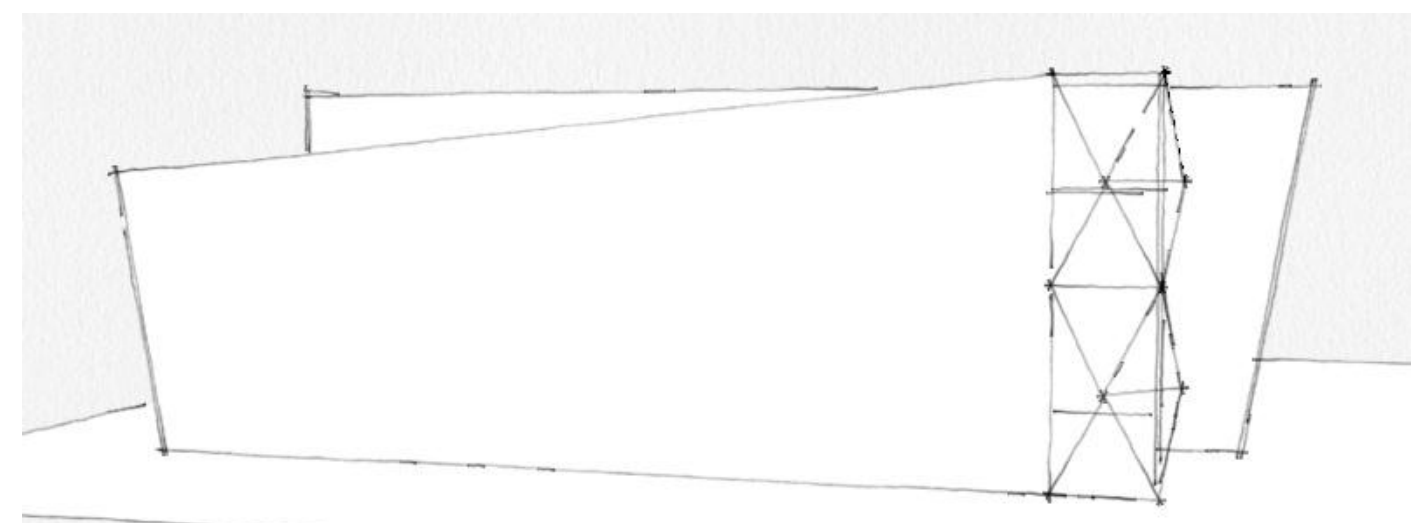

Figura 105: Etapa 06 do desenvolvimento projetual. Fonte: Desenhos do autor.

\subsubsection{ABERTURAS}

As aberturas da edificação também foram estudadas e analisadas, após a definição da organização interna dos ambientes estabelecidos no programa de necessidades. Todos os espaços dentro do museu possuem aberturas para o exterior, de forma a trazer conforto para os usuários. Entretanto, com o intuito de manter o projeto fiel aos seus conceitos de equilíbrio assimétrico e contraste, as esquadrias foram determinadas através da composição de aberturas predominantemente verticais ou horizontais, criando assim, um ritmo novo para o partido arquitetônico (Figura 106, 107, 108 e 109).

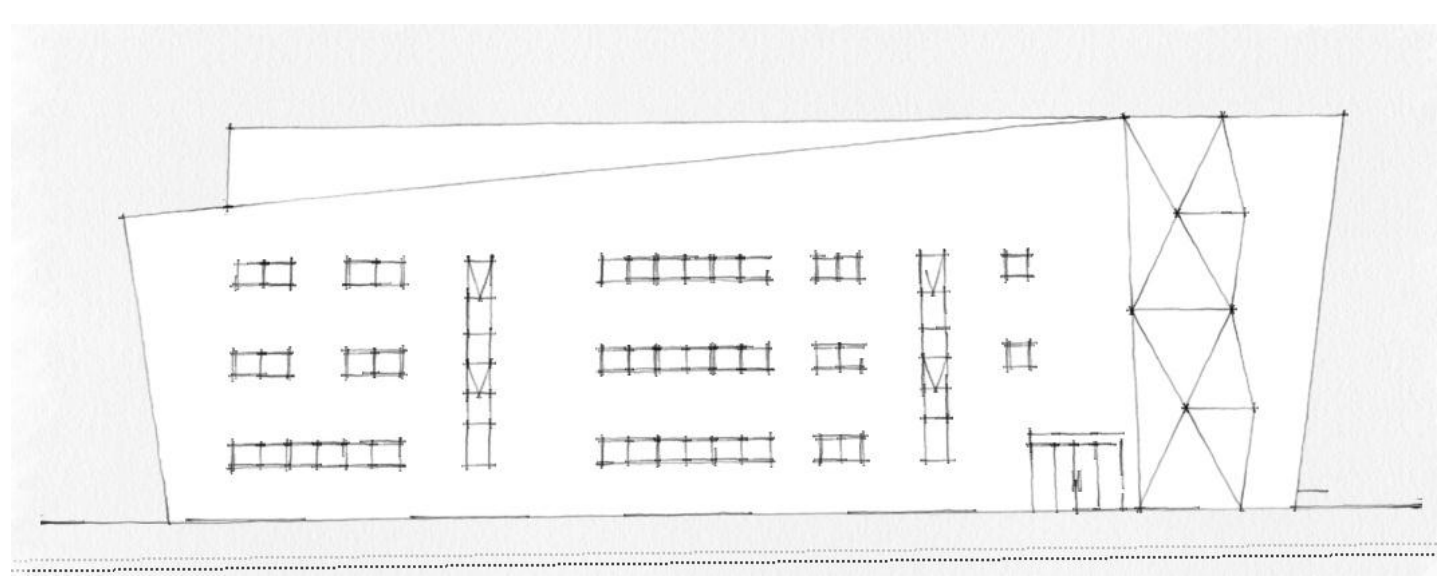

Figura 106: Fachada frontal.

Fonte: Desenhos do autor. 


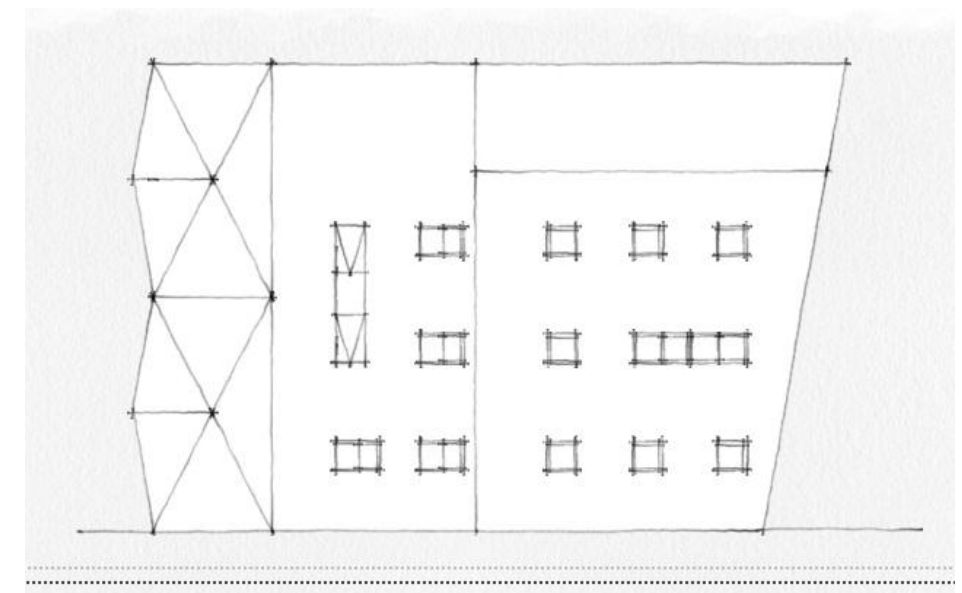

Figura 107. Fachada lateral.

Fonte: Desenhos do autor.

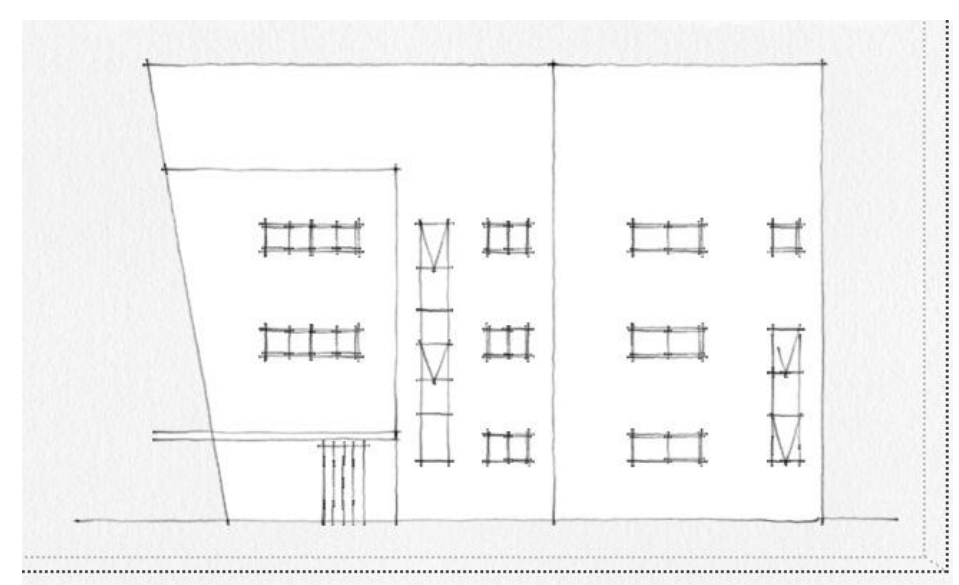

Figura 108. Fachada lateral.

Fonte: Desenhos do autor.

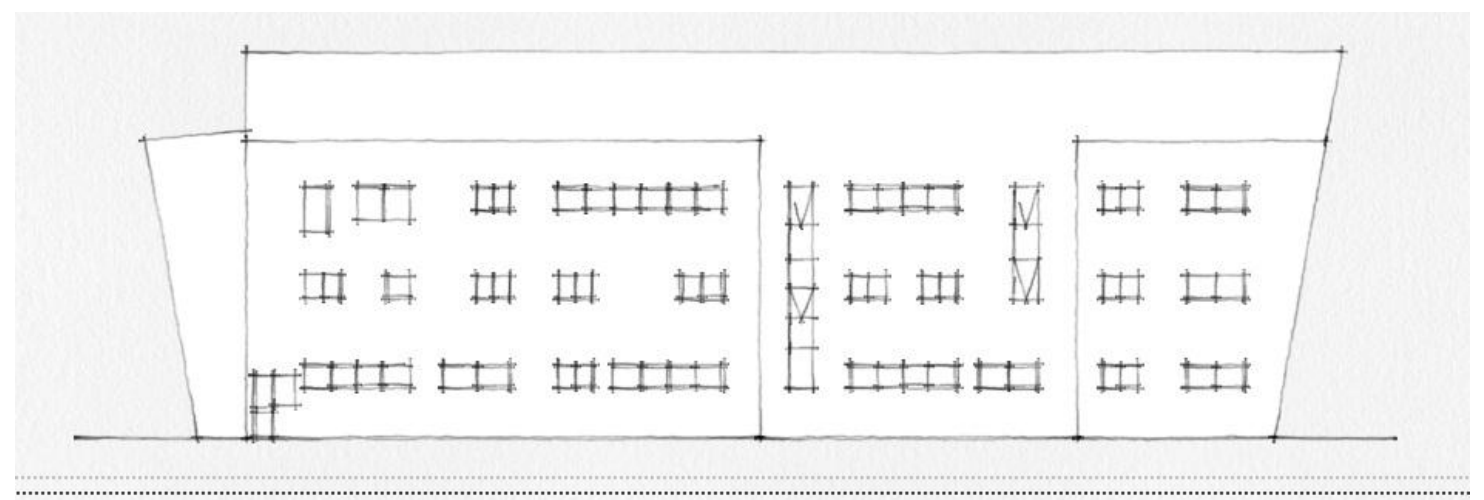

Figura 109: Fachada posterior.

Fonte: Desenhos do autor. 


\subsubsection{PARTIDO ARQUITETÔNICO FINAL}

Ao final da elaboração para a proposta volumétrica do museu, encontrou-se um pequeno conflito em relação à proporção final, caracterizado por uma excessiva distância entre a última esquadria e o término da alvenaria, causando certo desconforto visual. Entretanto, tal sensação foi bloqueada, de forma a não ferir os conceitos atribuídos aos projetos. Para esse bloqueio, desenvolveu-se uma composição cromática, incorporando um elemento horizontal, com o objetivo de criar diferentes profundidades e limites, gerando sensações de planos diferentes e dessa forma, e desviando a atenção do observador da distancia.

Essa combinação de cores também foi concebida em harmonia tanto com o entorno, quanto com a linguagem do partido arquitetônico. Dessa forma, o jogo de profundidade foi realizado utilizando-se dois tipos iguais de revestimento, a pastilha, porém com tonalidades diferentes, sendo a cor escura chamada Bronze e a mais clara, Argila.

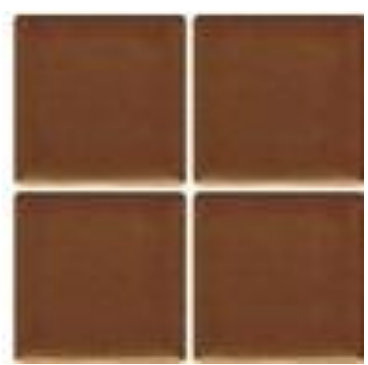

Figura 111: Pastilha Bronze.

Fonte: Desenhos do autor.

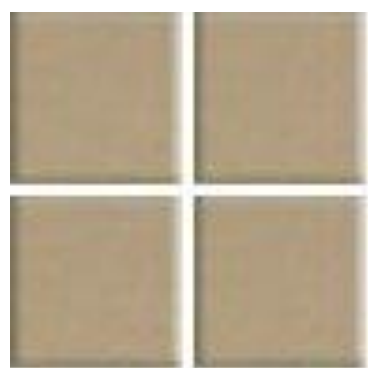

Figura 110: Pastilha Argila.

Fonte: Desenhos do autor.

Através dessa escolha, atingiu-se o resultado final (Figura 112, 113, 114 e 115). 


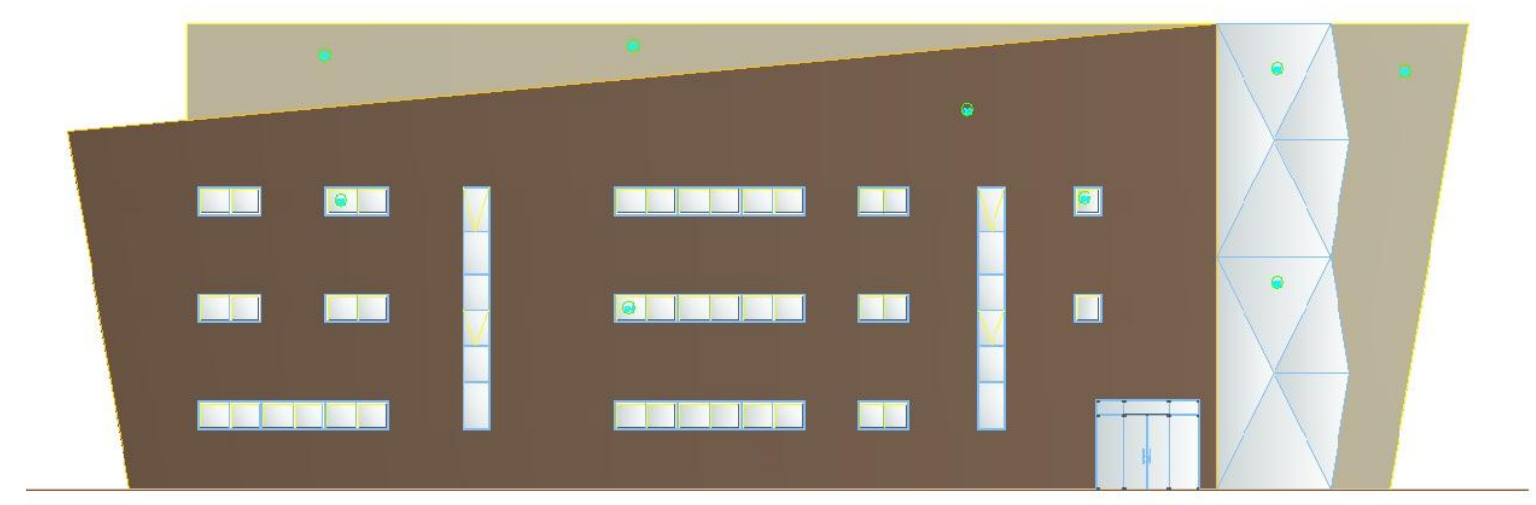

ESTUDO CROMÁTICO _ED IN

Figura 112: Partido Arquitetônico final.

Fonte: Desenhos do autor.

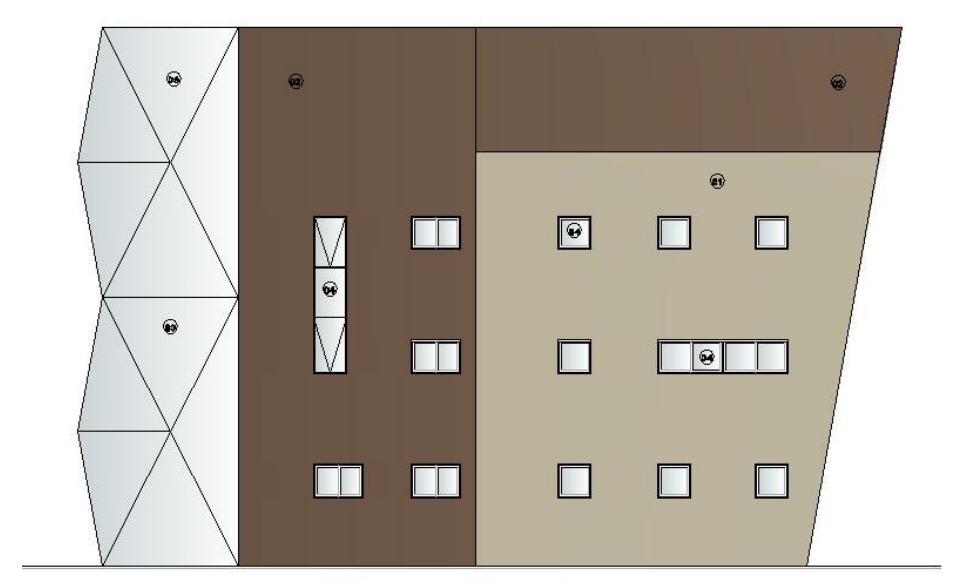

ESTUDO CROMATICO

Figura 113. Partido Arquitetônico final.

Fonte: Desenhos do autor.

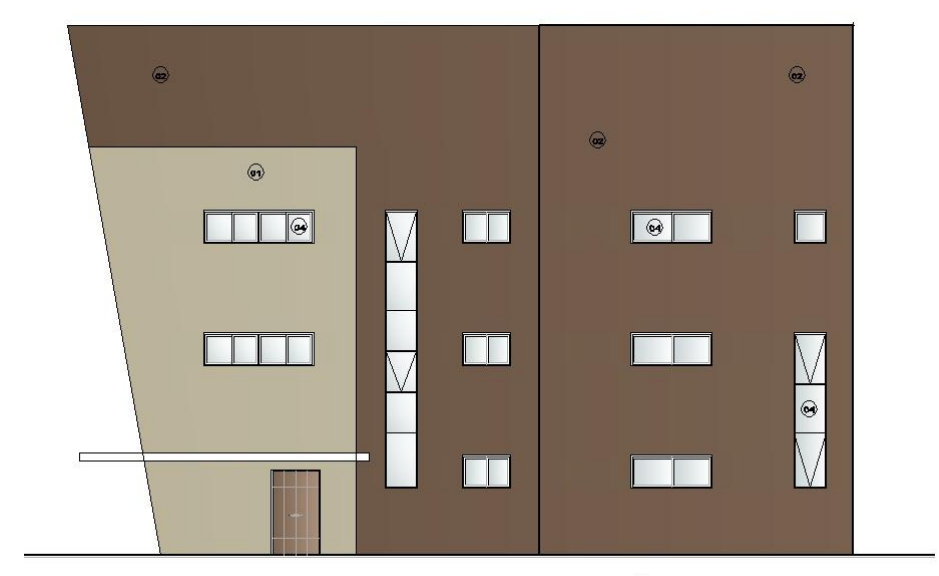

ESTUDO CROMÁTICO ....10.

Figura 114. Partido Arquitetônico final.

Fonte: Desenhos do autor. 


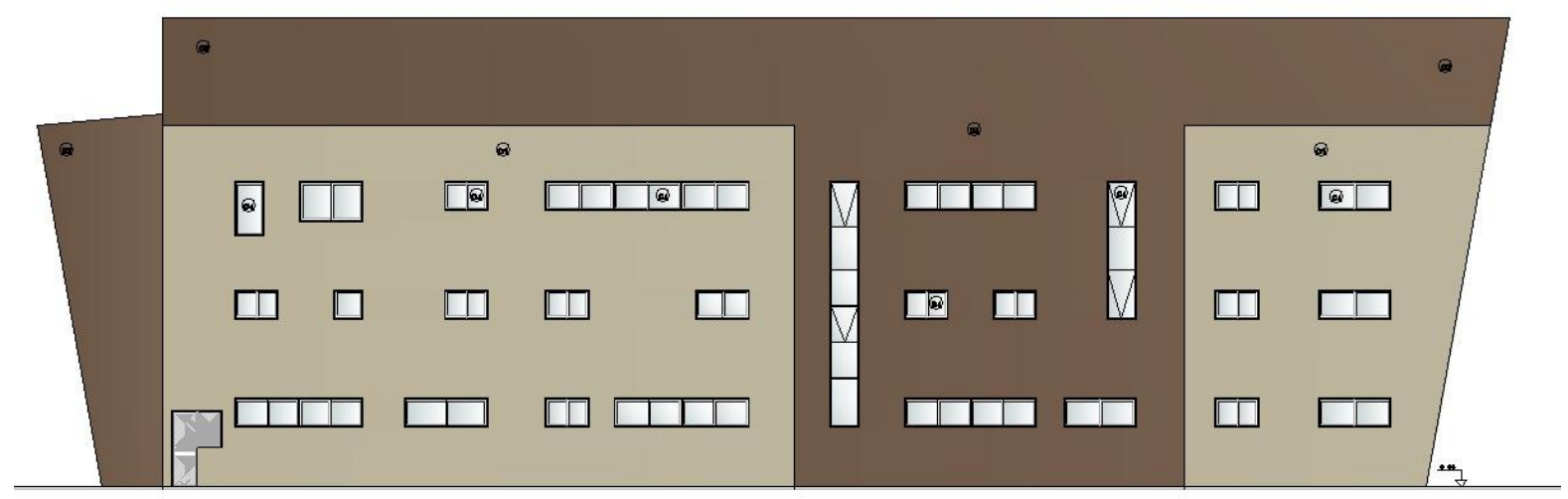

ESTUDO CROMATICO = $\rightarrow$

Figura 115. Partido Arquitetônico final.

Fonte: Desenhos do autor.

\subsubsection{AMBIENTES INTERNOS}

Por se tratar de um edifício que abriga objetos de valor, duas premissas foram de extrema importância na composição arquitetônica e na distribuição espacial dos ambientes, sendo elas o conforto térmico e a segurança da coleção.

Portanto, foram definidos dois acessos ao interior do edifício. Um acesso público, localizado na fachada principal do edifício e próximo a estrutura metálica lateral. E outro situado na fachada lateral, posicionado em um local menos visível e próximo a vaga de estacionamento para carga e descarga (Figura 116).

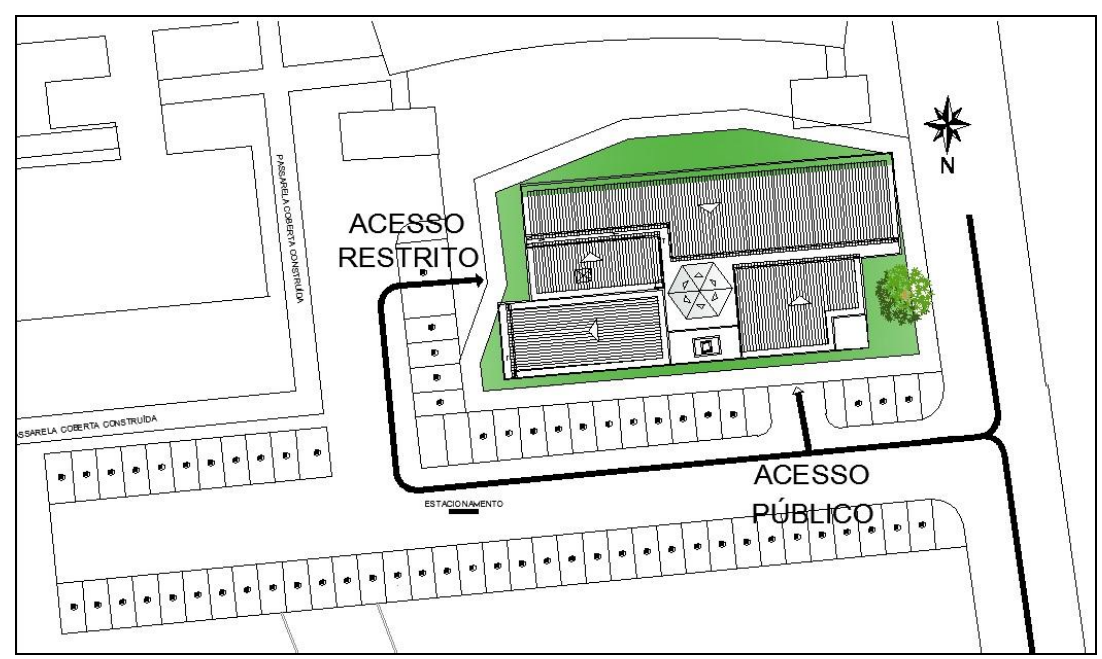

Figura 116. Localização dos acessos do museu. Fonte: Desenhos do autor. 
Do ponto de vista da conservação preventiva do acervo do museu de Geociências, alguns fatores foram adotados. Todavia, como a coleção do museu é em sua maioria constituída por minerais, como gemas, rochas e cristais, apenas algumas medidas tornam-se indispensáveis, uma vez que o acervo não necessita de cuidados extremos. O projeto então optou por abrigar a coleção em um espaço banhado por amplas aberturas, com o objetivo de tornar as exposições um lugar claro e arejado. Para tal efeito, foi levada em consideração tanto a segurança do edifício, quanto o percurso museográfico vivenciado pelo visitante. Sendo assim, todas as aberturas possuem um peitoril alto, com $1.65 \mathrm{~m}$.

No que diz respeito às exposições, elas foram a principal preocupação do projeto. De acordo com Scheiner (2006), as exposições são fundamentalmente, os locais que exibem a filosofia da instituição, e devem ser priorizados, pois através desse espaço ocorre o contato maior com o publico visitante.

As exposições do projeto aqui proposto estão presentes em todos os três pavimentos, sendo as permanentes localizadas no térreo e no segundo pavimento e a temporária no terceiro pavimento. Com o intuito de estabelecer uma integração entre as três, foi criada uma iluminação zenital por meio da criação de uma abertura na laje do segundo e terceiro andar, caracterizado pela forma de um dodecagóno ${ }^{5}$. Espaço este, que por sua vez, será destinado a abrigar peças maiores da coleção, a exemplo de grandes pedras, ou fósseis (Figura 117 e 118).

\footnotetext{
${ }^{5}$ Polígono com doze lados iguais.
} 


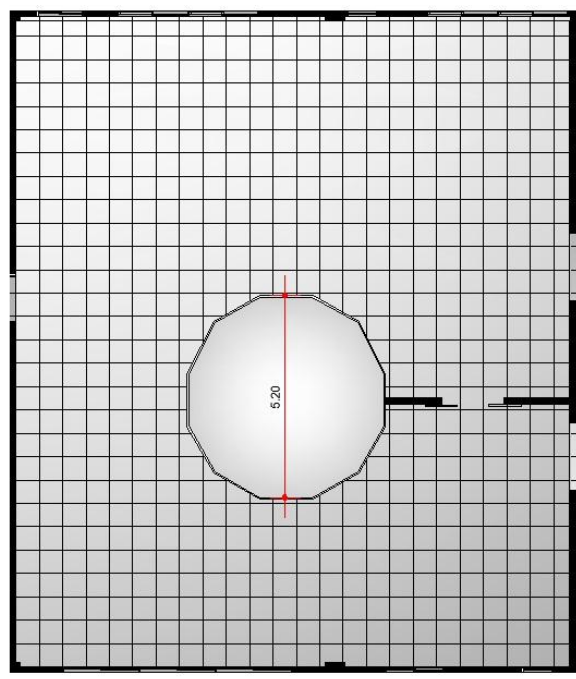

Figura 117: Dodecagóno em planta no pavimento térreo.

Fonte: Desenhos do autor.

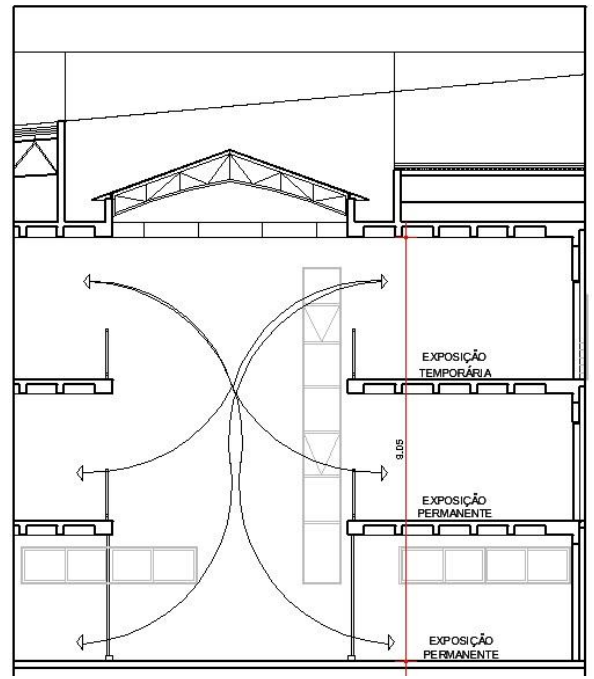

Figura 118: Secção esquemática da abertura zenital e consequente integração entre as exposições.

Fonte: Desenhos do autor.

Ainda com relação aos cuidados com o acervo, outro ambiente priorizado no projeto foi a reserva técnica, por tratar-se de um dos locais mais restritos do museu, uma vez que nele guarda-se toda a coleção da instituição. Tal prioridade configurou-se em posicionar esse ambiente de forma estratégica e privilegiada perante os demais. Dessa forma, o espaço destinado a reserva, recebe incidência solar pelo período da manhã, deixando o acervo a condições mais amenas de temperatura.

Visando ainda, a conservação preventiva da coleção, foram instaladas aberturas cruzadas no espaço, tornando-o um local ventilado e iluminado. Tal fato configurou-se como uma necessidade, pois como a coleção não requer controles rigorosos de temperatura, a preocupação primordial não foi quanto a temperatura do ambiente, e sim quanto a mudanças bruscas de temperatura, este sim um fator prejudicial ao acervo. Sendo assim, a reserva técnica foi projetada de modo a abrigar adequadamente a coleção, em caso de indisponibilidade de climatização artificial.

Com o intuito de transpor para o interior do edifício a filosofia da volumetria obtida, foram criados painéis decorativos, valendo-se das relações de profundidade obtidas através de composições cromáticas. Tal combinação resultou em uma pequena ilusão de ótica (Figura 119), onde as cores foram definidas de forma a criar associações aos metais Bronze, Prata e Cobre. As peças foram agrupadas e posicionadas em paredes estratégicas, uma em cada andar. 

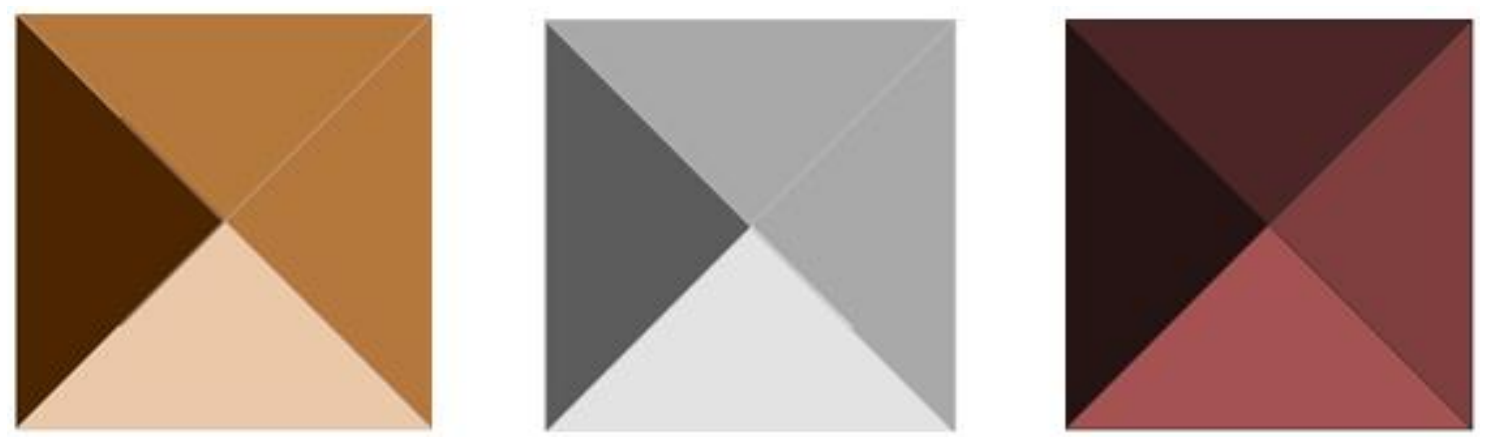

Figura 119: Painéis geométricos criados a partir da ilusão de ótica. Fonte: Desenhos do autor.

O hall de entrada do edifício também foi projetado de forma a trazer características da fachada ao interior. Desse modo, optou-se por introduzir uma escada helicoidal inscrita em uma quadrado, incorporando o contraste da forma circular com a forma quadrada. A escada é constituída de uma estrutura metálica com degraus de vidro leitoso, e guarda corpo em vidro temperado incolor com 10mm de espessura. Tais escolhas adicionaram leveza, amplitude e cristalinidade ao hall de entrada.

As demais compartimentações internas, foram organizadas de acordo com o programa de necessidades determinado e adotando os princípios estabelecidos pela Lei de Acessibilidade (Decreto-lei 5296, de 2 de dezembro de 2004), na qual a acessibilidade em espaços físicos consiste no direito à eliminação de barreiras arquitetônicas e à possibilidade de comunicação, de acesso físico, e de equipamentos.

Dessa forma, considerou-se a questão da mobilidade de portadores de necessidades especiais do tipo físico, buscando solucionar as dificuldades de locomoção, de estadia em determinado ambiente e de utilização dos equipamentos e estruturas disponíveis por parte de cadeirantes. O projeto então faz uso de amplas circulações e determina locais com condições apropriadas para sua permanência (vagas de estacionamento reservadas e área livre para posicionamento e giro no auditório). Com o intuito de contemplar a acessibilidade em todos os aspectos, foram adotadas outras medidas, como a determinação de que todos os banheiros fossem dotados de cabines especiais com vasos e equipamentos adequados para a utilização por portadores de necessidades físicas.

A expansão do Instituto de Geociências da UFPa, tanto na graduação, quanto na pósgraduação e por meio das pesquisas realizadas pelo Grupo de Mineralogia e Geoquímica 
Aplicada demandam por uma estrutura física que possa comportar essa evolução e torne-se um polo atrativo dentro da Universidade. De forma que o parque geocientífico possa usufruir de um projeto que contemple tanto as funções necessárias à formação acadêmica discente, quanto à divulgação acerca do estudo das Geociências para os visitantes e interessados em adquirir conhecimento acerca da coleção. Portanto, a proposta arquitetônica para o Museu de História Geológica da Amazônia propõe uma volumetria atrativa, que reflita o acervo a ser descoberto e admitindo como princípio fundamental o estímulo a novas descobertas.

\subsection{MEMORIAL DESCRITIVO}

\subsubsection{CARACTERÍSTICAS GERAIS DO EDÍFICIO}

A estrutura volumétrica da proposta final é constituída por formas geométricas, concebidas a partir da integração de eixos verticais, horizontais e inclinados. O partido arquitetônico é idealizado a partir de dois volumes distintos, integrados a uma estrutura metálica situada na lateral direita do volume a frente, formada pelo sistema Spider Glass.

As fachadas receberam composições cromáticas caracterizadas por duas cores distintas de revestimentos, sendo eles a Pastilha Jatobá na cor Bronze e a Pastilha Jatobá na cor Bege Argila, ambas no formato de $5 \times 5 \mathrm{~cm}$.

A edificação é organizada em três andares, estruturados a partir de lajes de concreto, com exceção para as áreas de exposições do museu, as quais receberam laje cogumelo nervuradas. O forro utilizado é o forro em gesso acartonado Knauf.

\subsubsection{ACESSOS E ESQUADRIAS}

Todas as esquadrias do edifício são esquadrias em alumínio anodizado com vidro temperado de $8 \mathrm{~mm}$ de espessura.

O acesso principal do museu é realizado através de uma porta automática Manusa, com vidro temperado incolor e $10 \mathrm{~mm}$ de espessura. $\mathrm{O}$ acesso de funcionários é feito por uma porta de abrir em duas folhas, em MDF, revestida com laminado melamínico wengué.

As marquises, tanto do acesso público, quanto do acesso de funcionários são em vidro temperado incolor, com espessura de $10 \mathrm{~mm}$. 


\subsubsection{CIRCULAÇÕES VERTICAIS}

A escada do hall de entrada é caracterizada como uma escada helicoidal, inscrita em um quadrado. Ela é sustentada por uma estrutura metálica, com degraus em vidro leitoso e guarda corpo em alumínio anodizado e vidro temperado com 10mm de espessura.

A circulação vertical do setor restrito do museu é realizada através de uma escada de cimento pintado.

O guarda-corpo do segundo pavimento, assim como os localizados nos três andares de exposição são constituídos de alumínio anodizado e vidro temperado, com $10 \mathrm{~mm}$ de espessura.

\subsubsection{COBERTURA}

O telhado da edificação é constituído de telha termoácustica Eternit do tipo sanduíche, um sistema caracterizado por uma telha, um isolante (poliestireno expandido) e outra telha. Tal escolha foi adotada por se tratar de uma boa solução ao clima de Belém, uma vez que a telha funciona como um isolante térmico e acústico.

A estrutura da cobertura é realizada através de treliças metálicas.

As calhas são em concreto impermeabilizado. Os rufos também são em concreto.

A laje técnica é caracterizada por uma laje impermeabilizada.

A cobertura da edificação também possui uma circulação zenital, realizada através de um domus de iluminação, cuja cobertura é feita com o vidro Cebrace Cool Lite KNT.

\subsubsection{ESPECIFICAÇÕES POR AMBIENTE:}


TABELA 3: ESPECIFICAÇÕES POR AMBIENTE

\begin{tabular}{|c|c|c|c|c|c|c|c|}
\hline & $\begin{array}{ll} \\
2 \\
\end{array}$ & 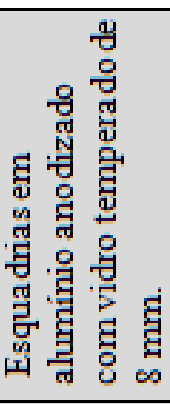 & 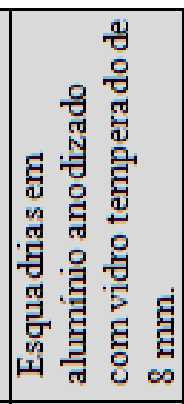 & 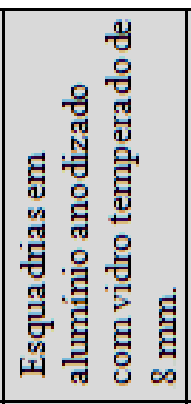 & 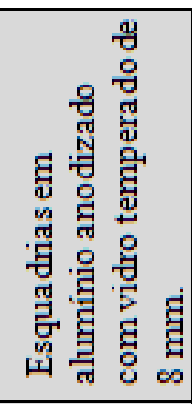 & 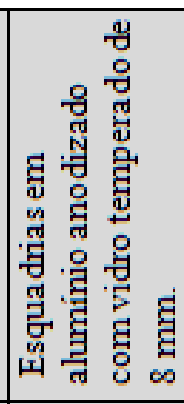 & 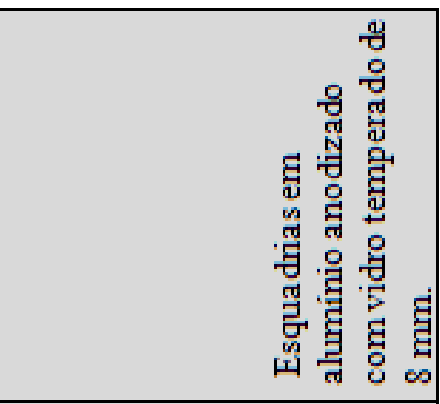 \\
\hline & ชิ & 죄 & 晹 & 壮 쾨 & 国 & 코 & 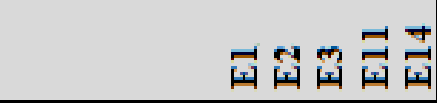 \\
\hline & 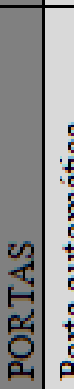 & 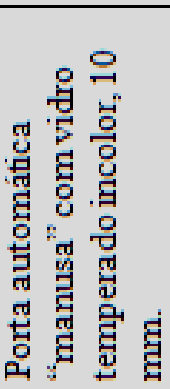 & 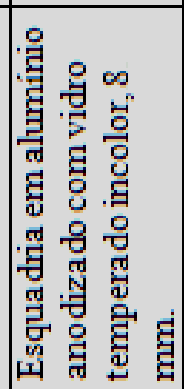 & 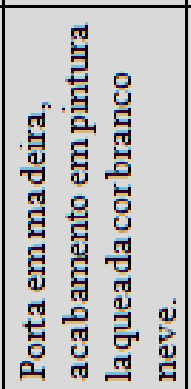 & 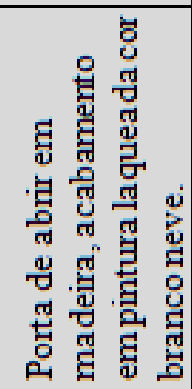 & 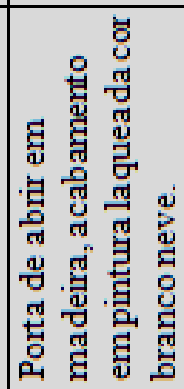 & 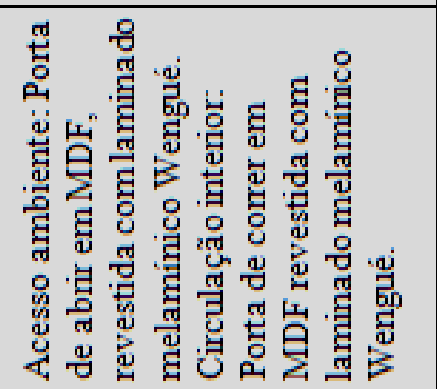 \\
\hline 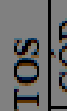 & ○ิ & $\overrightarrow{2}$ & ฉి & $\delta_{1}^{\prime}$ & \&े & $\mathcal{\Sigma}$ & 舟责 \\
\hline 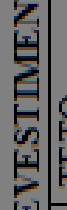 & $\begin{array}{l} \\
0 \\
\text { ⿶ㅚㅂ } \\
\end{array}$ & 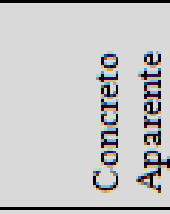 & 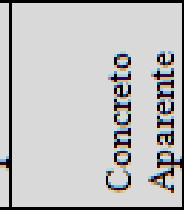 & 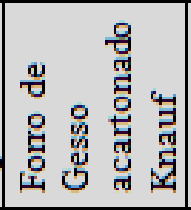 & 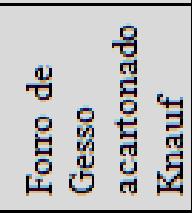 & 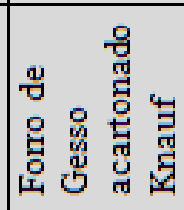 & 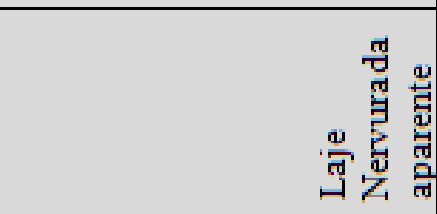 \\
\hline 됭 & ○ิ & 可 & 田 & I & I & $\mathbb{E}$ & 可 \\
\hline 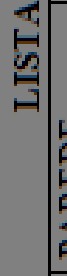 & 氙 & 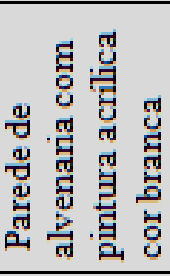 & 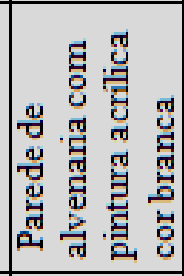 & 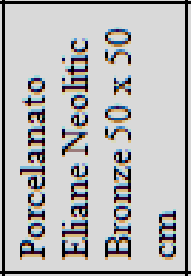 & 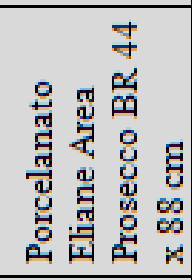 & 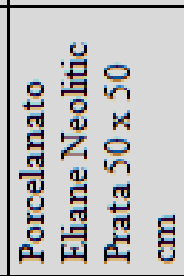 & 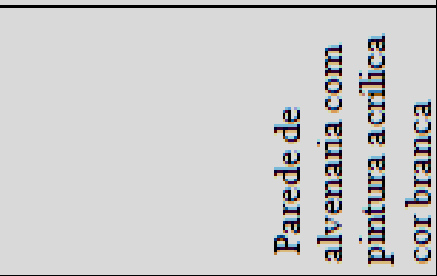 \\
\hline & 잉 & 武 & 斗 & 2 & 2 & 2 & 2 \\
\hline & 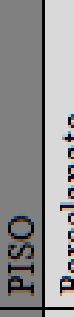 & 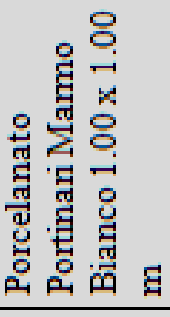 & 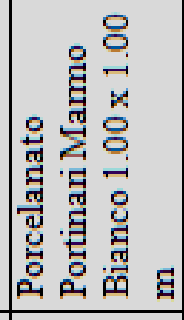 & 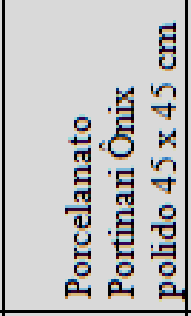 & 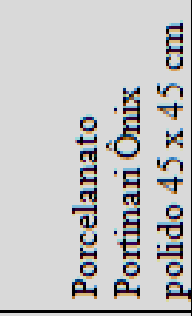 & 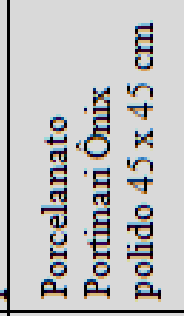 & 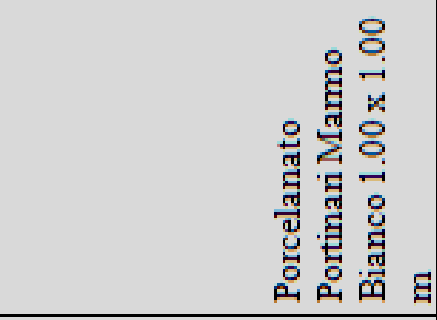 \\
\hline & ○ి & $\vec{Q}$ & $\overrightarrow{a_{1}}$ & $\overrightarrow{a_{1}}$ & $\vec{a}$ & $\overrightarrow{a_{1}}$ & $\vec{a}$ \\
\hline & 商 & 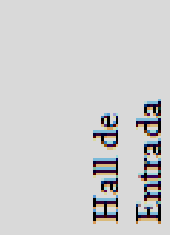 & : & 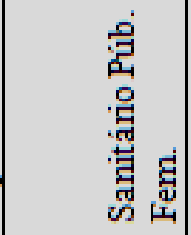 & 量 & 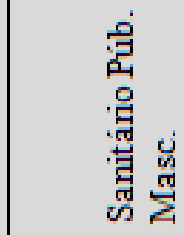 & 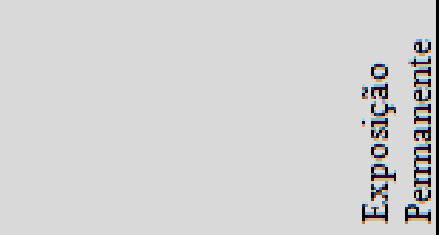 \\
\hline \multicolumn{8}{|c|}{ 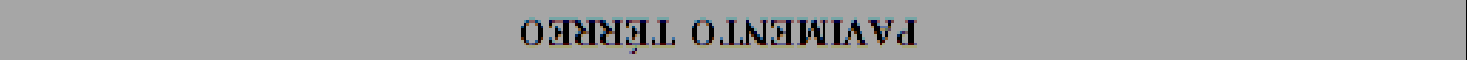 } \\
\hline
\end{tabular}




\begin{tabular}{|c|c|c|c|c|c|c|c|}
\hline | & 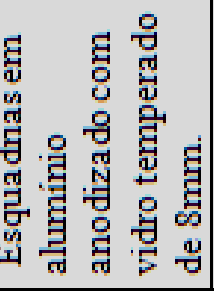 & 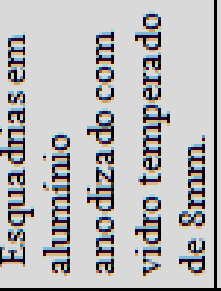 & 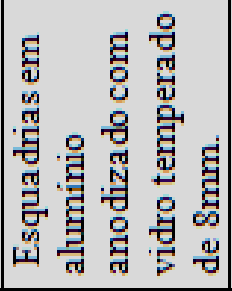 & 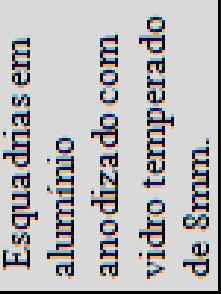 & 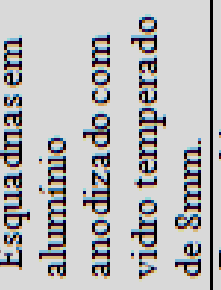 & 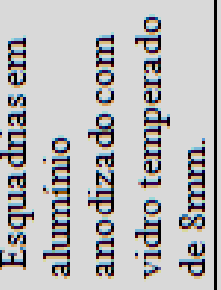 & \\
\hline O & | & 이 죄 & 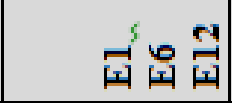 & 氖 & 焉 & | & | \\
\hline & 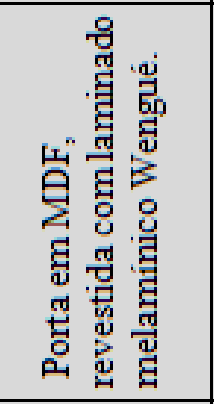 & 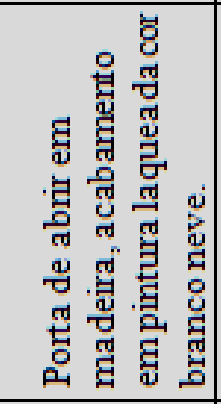 & 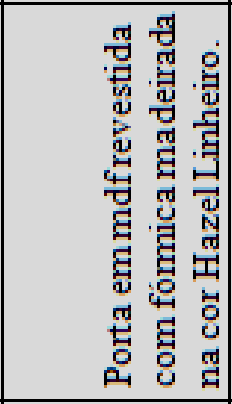 & 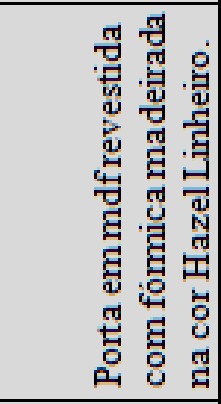 & 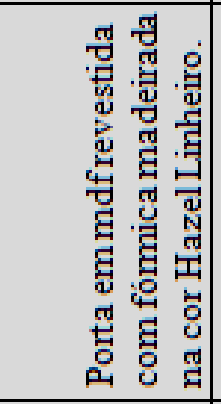 & 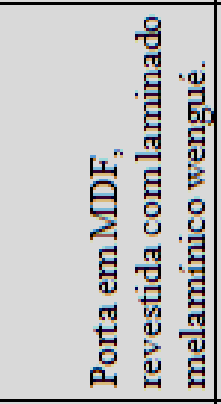 & 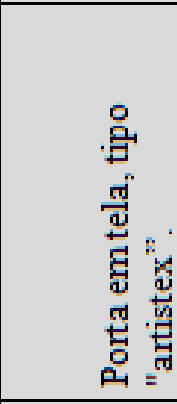 \\
\hline 잉 & $\stackrel{\infty}{\circ}$ & $\stackrel{\infty}{\infty}$ & 을 & $\tilde{\beta}_{1}$ & 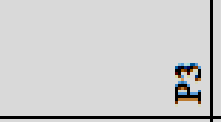 & $\stackrel{\infty}{\infty}$ & $\vec{a}$ \\
\hline $\begin{array}{l}\text { 옵 } \\
\text { 凷 }\end{array}$ & 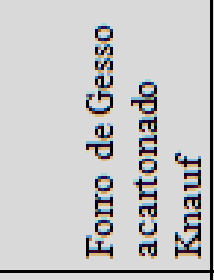 & 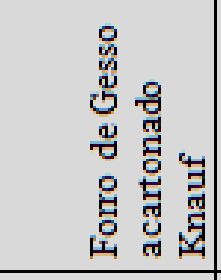 & 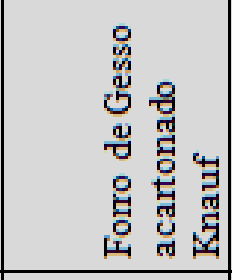 & 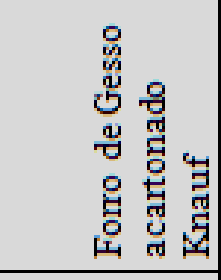 & 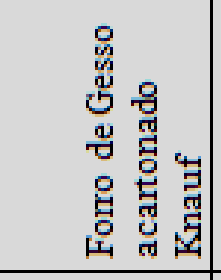 & 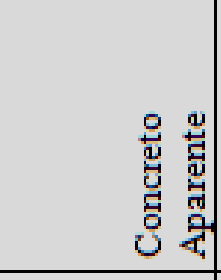 & 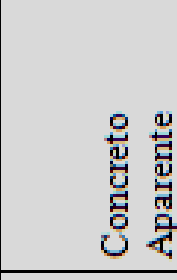 \\
\hline 엉 & 幽 & $\mathbb{E}$ & I & $\mathrm{I}$ & $\mathbb{2}$ & 正 & 匡 \\
\hline 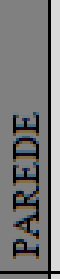 & 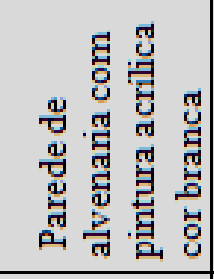 & 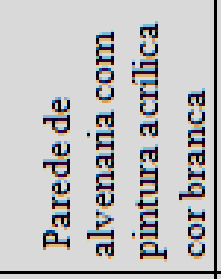 & 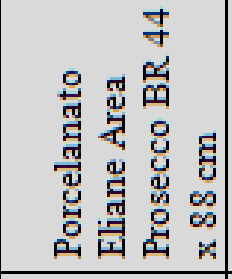 & 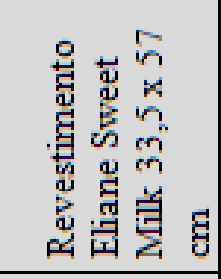 & 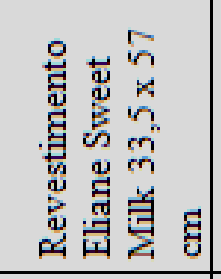 & 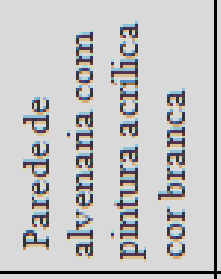 & 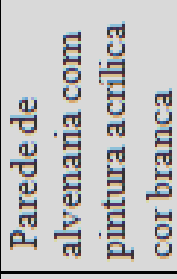 \\
\hline 8 & 2 & a & 2 & 离 & 芯 & 勻 & a \\
\hline $\begin{array}{l}\text { ○ } \\
\text { 品 }\end{array}$ & 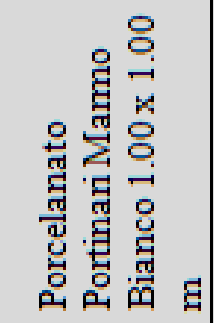 & 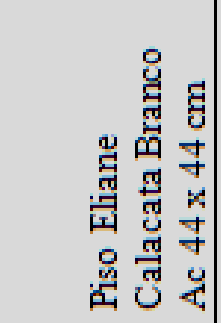 & 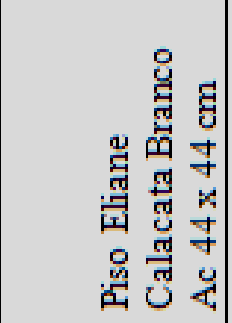 & 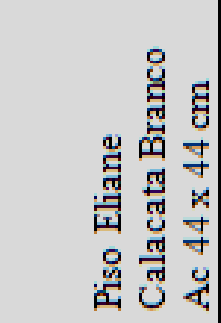 & 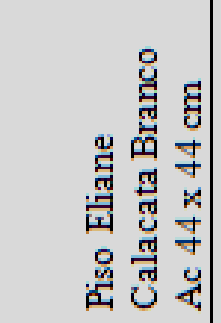 & 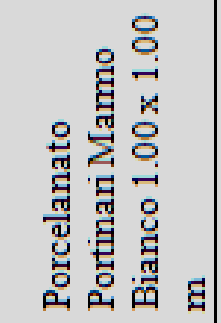 & 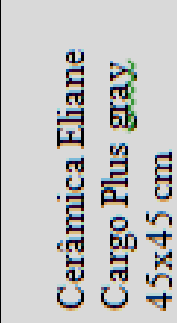 \\
\hline ن잉 & $\overrightarrow{B_{1}}$ & مै: & ผี & $\stackrel{1 / 2}{1}$ & ณ & $\overrightarrow{B_{1}}$ & is \\
\hline 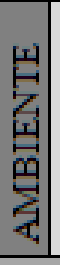 & 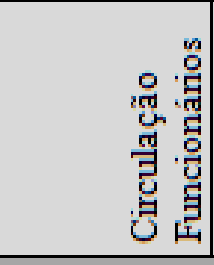 & 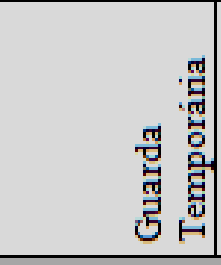 & 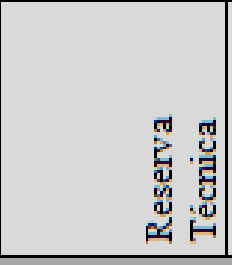 & 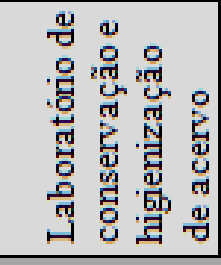 & 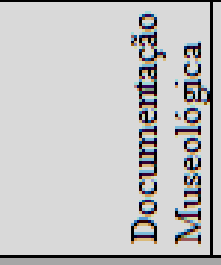 & 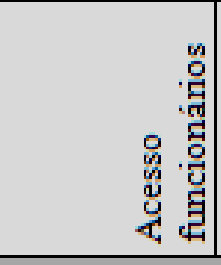 & $\begin{array}{l}\text { 苟 } \\
\text { 苟 }\end{array}$ \\
\hline \multicolumn{8}{|c|}{ 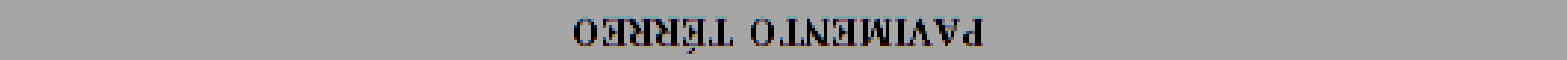 } \\
\hline
\end{tabular}




\begin{tabular}{|c|c|c|c|c|c|c|c|c|}
\hline 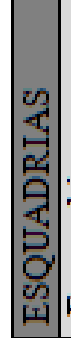 & 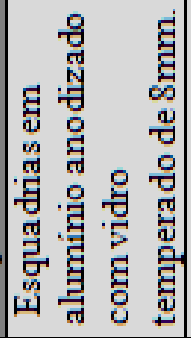 & 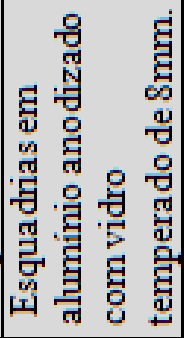 & 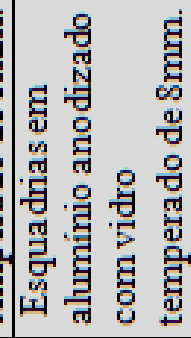 & 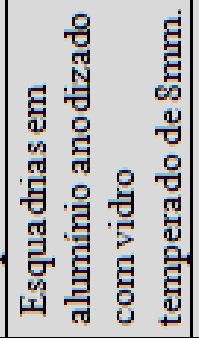 & 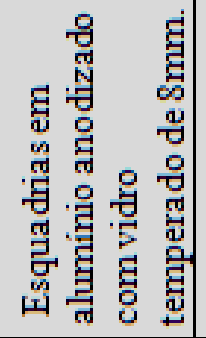 & 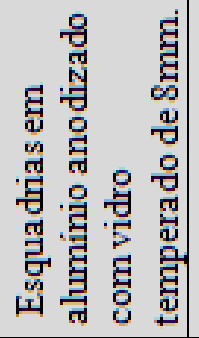 & 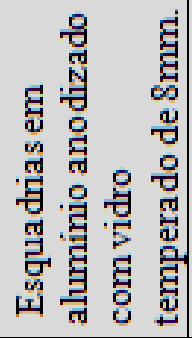 & 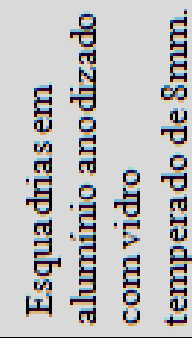 \\
\hline & 馬武 & 各 죔 & 国 & 全 & 馬 & 絰 & 고 조믹 & \\
\hline 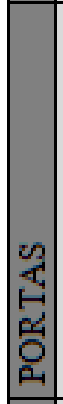 & 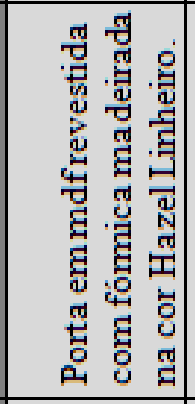 & 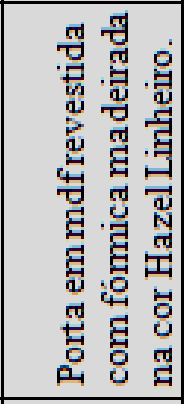 & 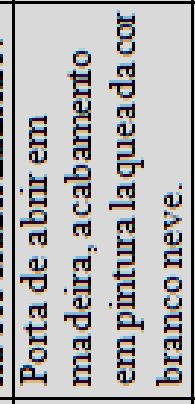 & 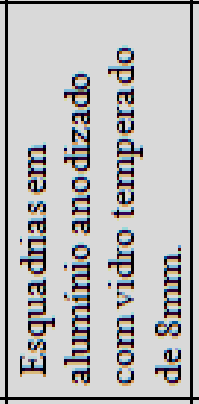 & 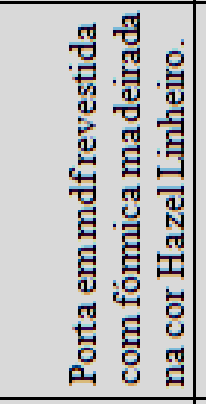 & 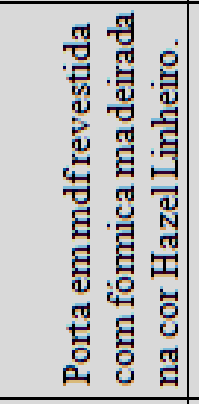 & 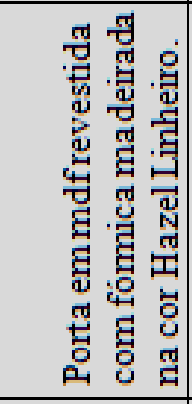 & 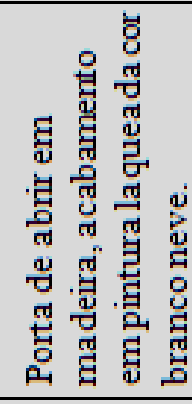 \\
\hline U & $\tilde{n}_{1}$ & 约 & \&े & $\overrightarrow{n_{1}}$ & $\tilde{n}_{1}$ & $\tilde{n}_{1}$ & $\tilde{\tilde{n}_{1}}$ & $\tilde{\alpha}$ \\
\hline $\begin{array}{l}\text { 옵 } \\
\text { 凷 } \\
\end{array}$ & 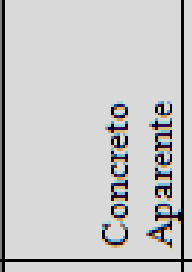 & 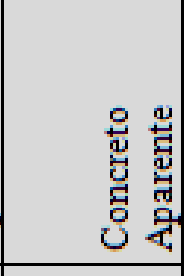 & 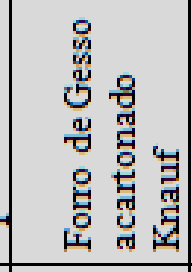 & 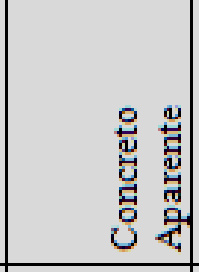 & 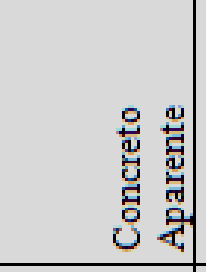 & 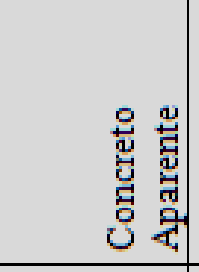 & 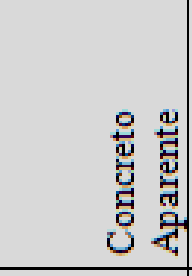 & 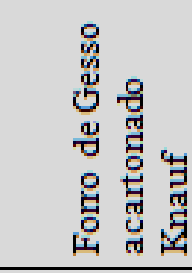 \\
\hline 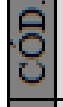 & $\overrightarrow{|r|}$ & 可 & I & 可 & 至 & 至 & 可 & $\mathfrak{I}$ \\
\hline 峢 & 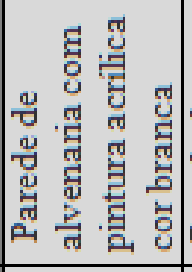 & 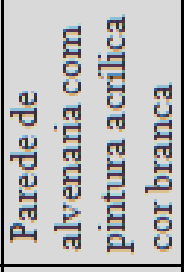 & 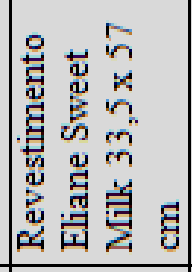 & 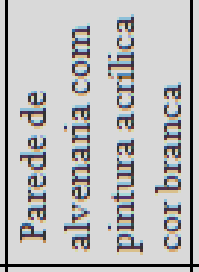 & 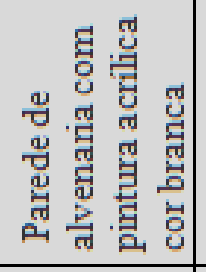 & 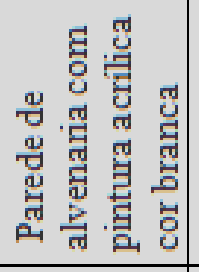 & 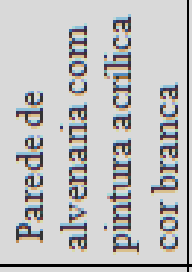 & 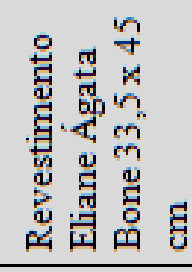 \\
\hline Oి & \& & 2 & 2 & क & 2 & 2 & क & 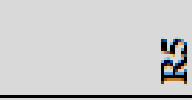 \\
\hline & 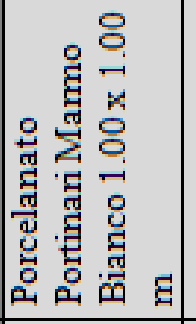 & 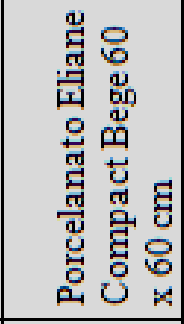 & 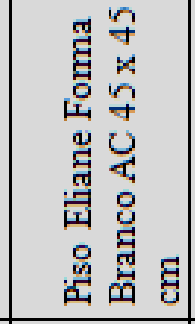 & 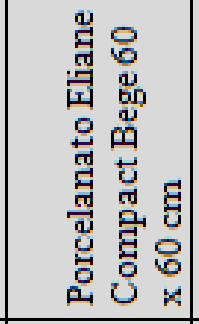 & 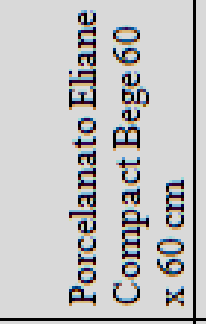 & 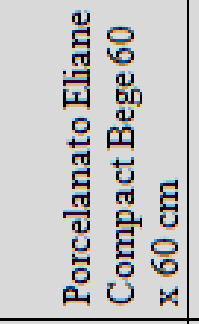 & 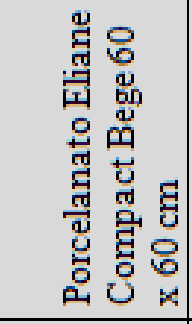 & 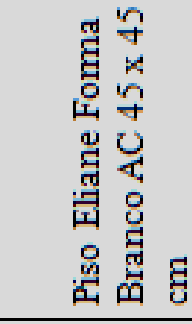 \\
\hline రิ) & $\theta_{1}$ & $\hat{\hat{n}_{1}}$ & $\tilde{D}_{1}$ & 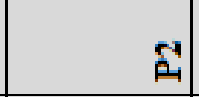 & $\hat{s}$ & $\Delta_{1}$ & $\Sigma_{1}$ & \& \\
\hline 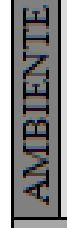 & 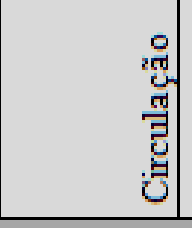 & 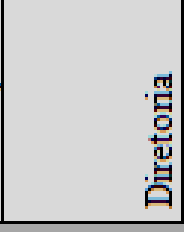 & 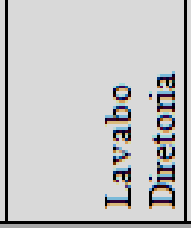 & : & 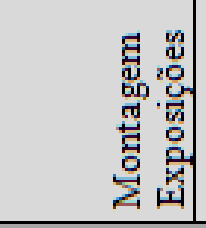 & 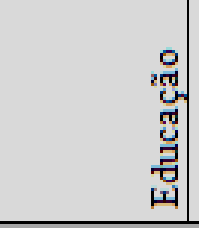 & 悬总总 & 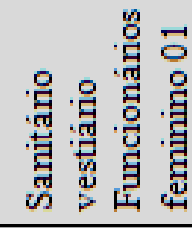 \\
\hline \multicolumn{9}{|c|}{ O.LN'GWLVVd } \\
\hline
\end{tabular}




\begin{tabular}{|c|c|c|c|c|c|c|c|c|c|}
\hline 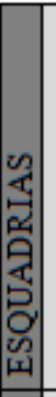 & 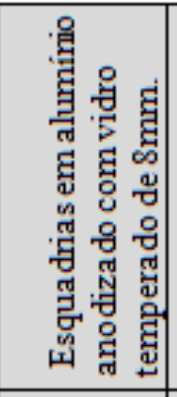 & 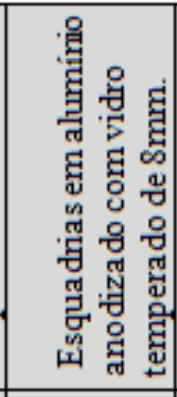 & 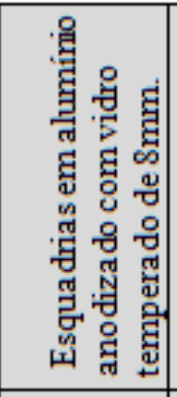 & 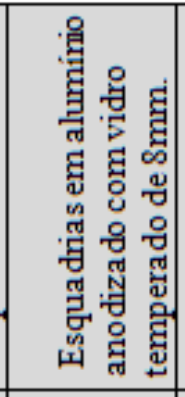 & 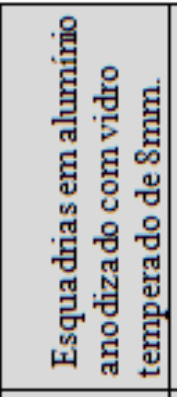 & & 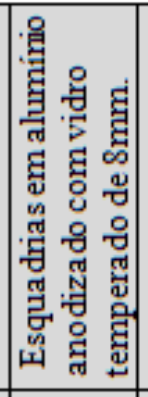 & 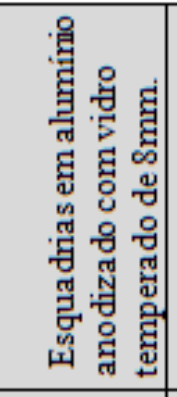 & 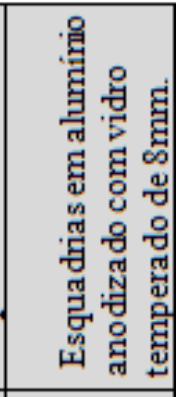 \\
\hline & 馬 & 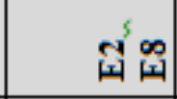 & 武 & 国 & 쾨 & 1 & $\begin{array}{lll}1 & 1 & 0 \\
1 & 1\end{array}$ & 国谷 & 国司国 \\
\hline & 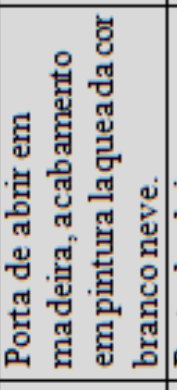 & 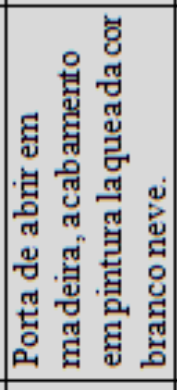 & 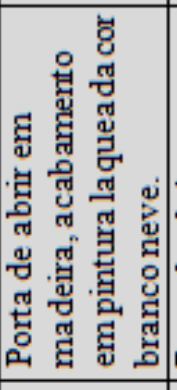 & 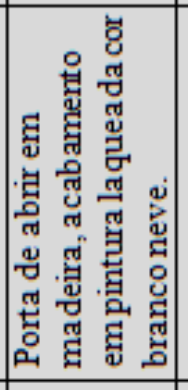 & 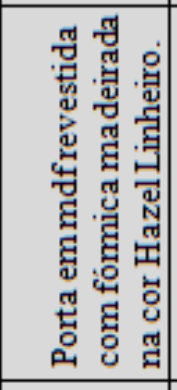 & 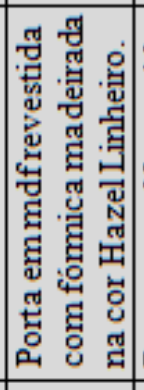 & 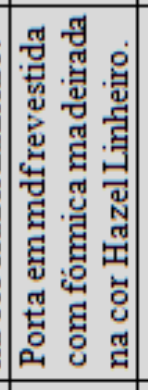 & 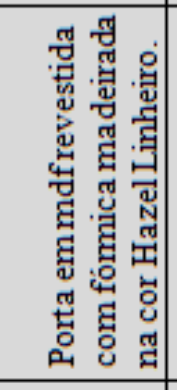 & 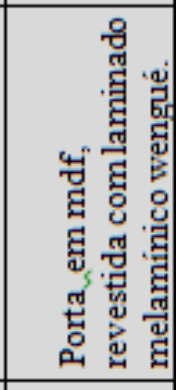 \\
\hline U & $\mathbf{A}^{\prime}$ & 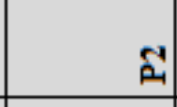 & $\AA^{-1}$ & \& & $\ddot{\hat{A}_{1}}$ & $\tilde{n_{1}}$ & $\tilde{\tilde{A}_{1}}$ & 2 & \\
\hline $\begin{array}{l}\stackrel{ }{:} \\
\text { 푀 }\end{array}$ & 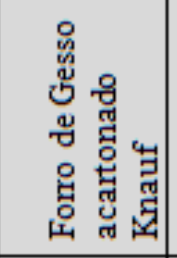 & 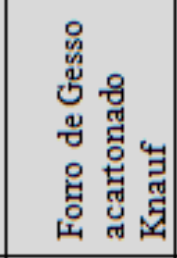 & 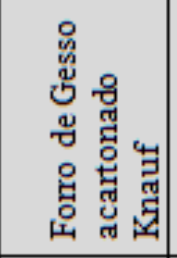 & 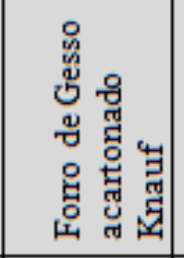 & 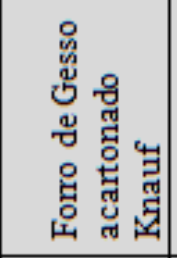 & 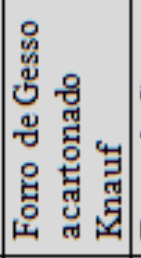 & 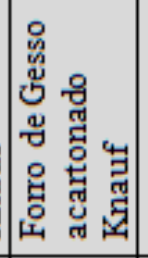 & 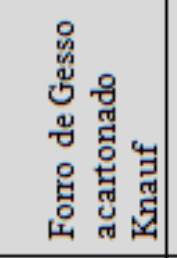 & 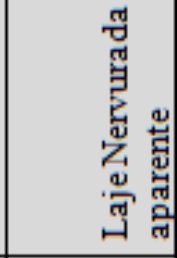 \\
\hline z & 剅 & జ & I & 到 & 到 & s & 到 & a & \\
\hline & 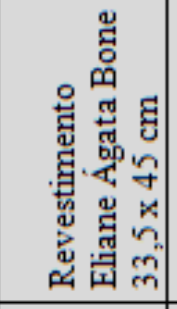 & 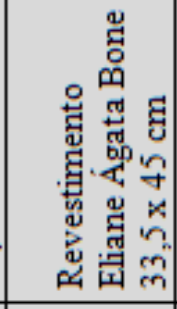 & 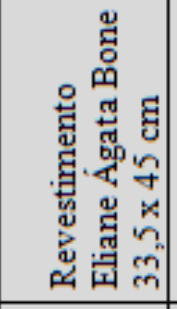 & 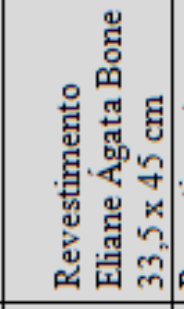 & 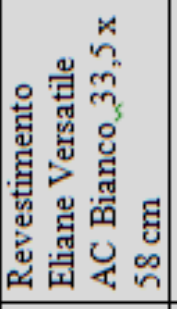 & 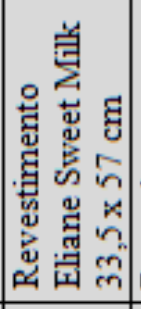 & 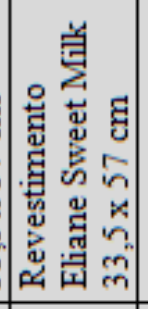 & 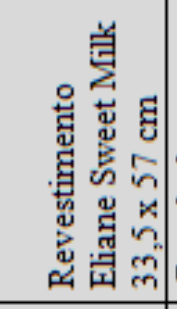 & 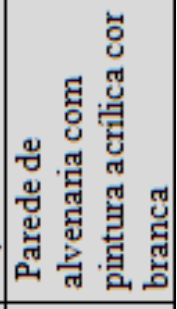 \\
\hline O & 电 & 2 & 酐 & 先 & ๕ి & $\overrightarrow{4}$ & 苾 & $\overrightarrow{4}$ & 电 \\
\hline 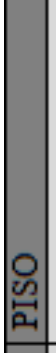 & 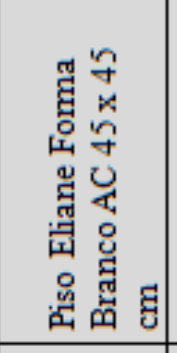 & 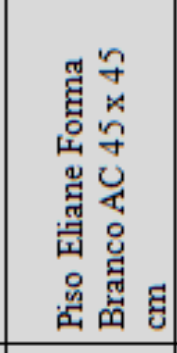 & 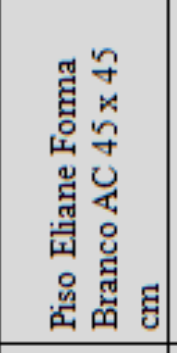 & 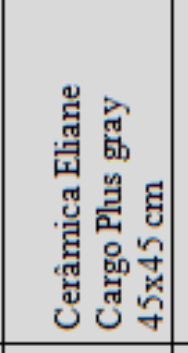 & 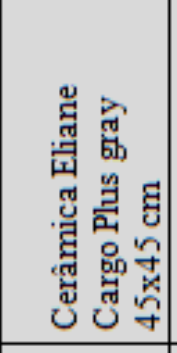 & 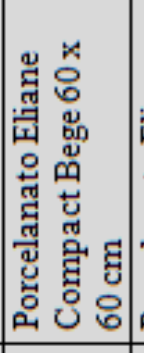 & 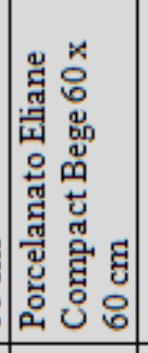 & 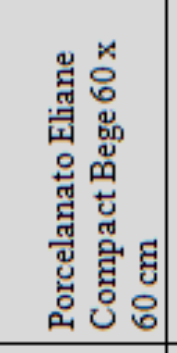 & 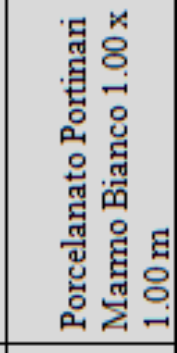 \\
\hline & ڤे & ڤి & $\bar{n}_{1}$ & $\hat{A_{1}}$ & $\omega_{1}$ & $\S_{1}^{-1}$ & $\Sigma_{1}$ & & $a_{1}$ \\
\hline & 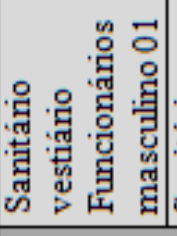 & 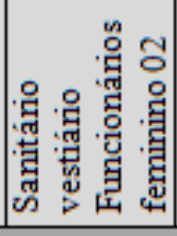 & 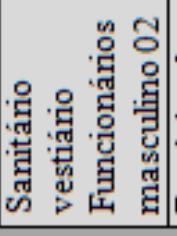 & 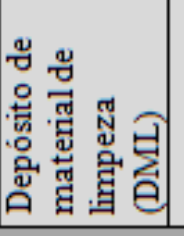 & & 解 & 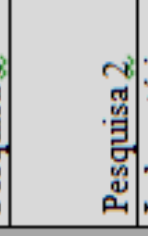 & 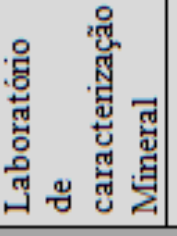 & 党 \\
\hline \multicolumn{10}{|c|}{ O.LNGWIAVA } \\
\hline
\end{tabular}




\begin{tabular}{|c|c|c|c|c|c|c|}
\hline 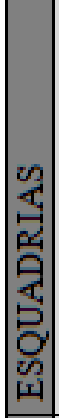 & 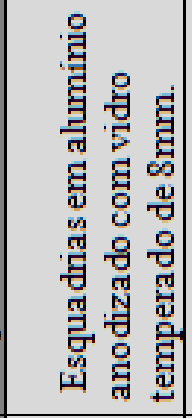 & 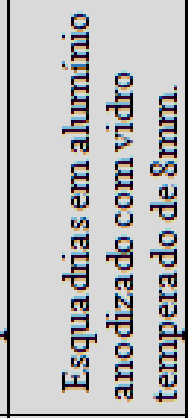 & 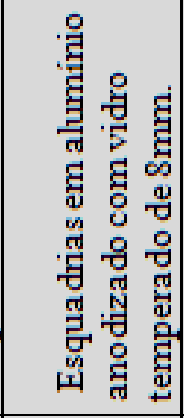 & 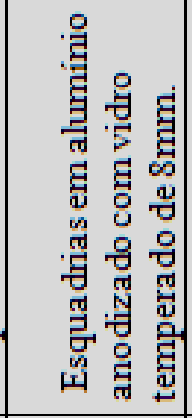 & 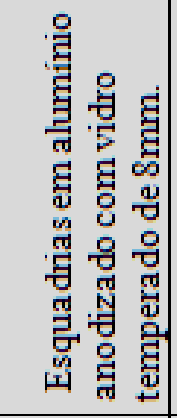 & 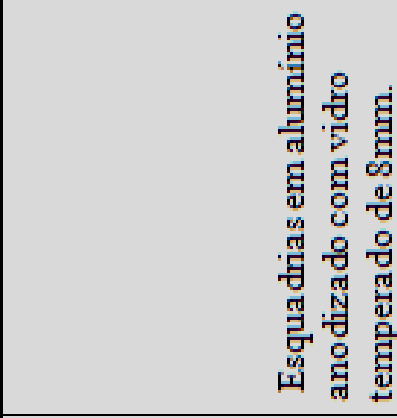 \\
\hline $\begin{array}{l}0 \\
0 \\
0\end{array}$ & 쾨점 & 氠 & 至国 & 国 & 武 & 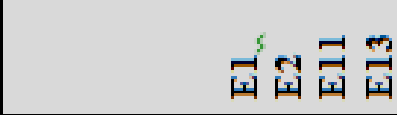 \\
\hline 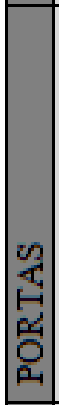 & 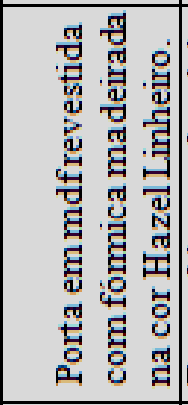 & 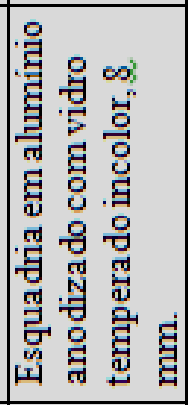 & 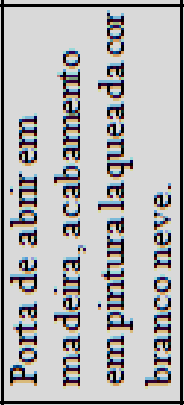 & 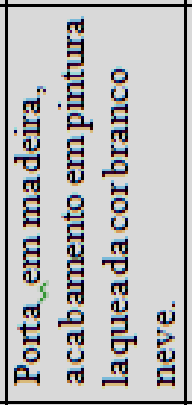 & 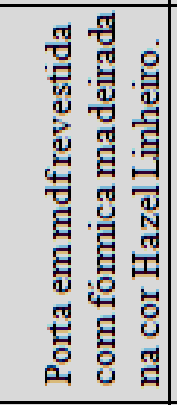 & 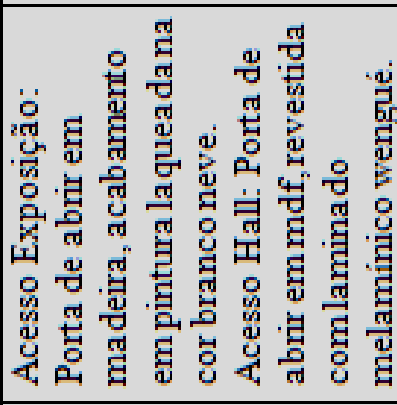 \\
\hline ○ి & $\tilde{\tilde{n}_{1}}$ & ฉి & $\delta_{1}^{\prime}$ & $\delta_{1}^{\prime}$ & $\ddot{n}_{1}$ & 욤 \\
\hline $\begin{array}{l}\text { 을 } \\
\text { 国 } \\
\end{array}$ & 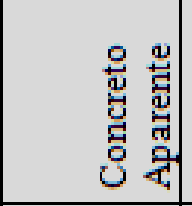 & 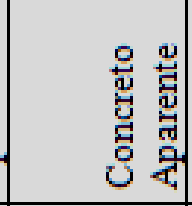 & 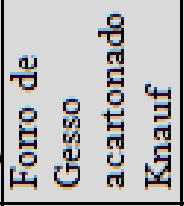 & 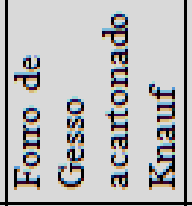 & 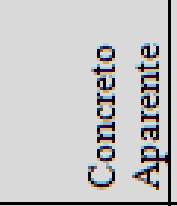 & 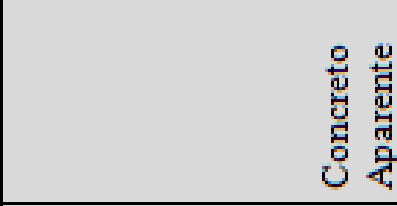 \\
\hline ○ి & 可 & 正 & \& & 到 & 可 & 匡 \\
\hline 眰 & 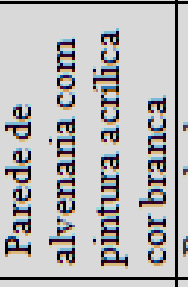 & 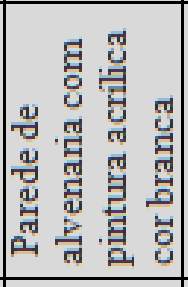 & 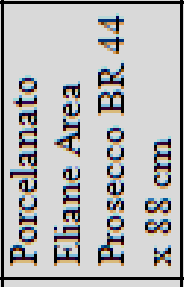 & 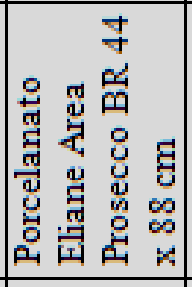 & 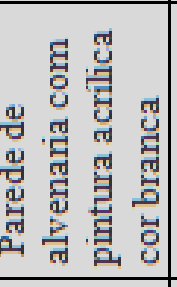 & 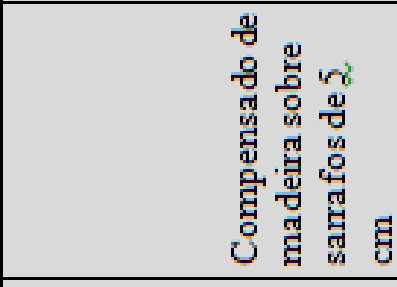 \\
\hline ○ి & 幽 & 2 & 2 & 2 & 望 & 虫 \\
\hline $\begin{array}{l} \\
0 \\
\text { 㟔 } \\
\end{array}$ & 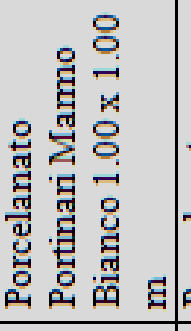 & 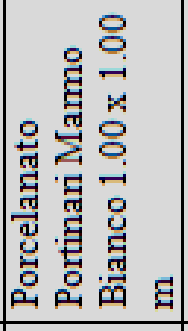 & 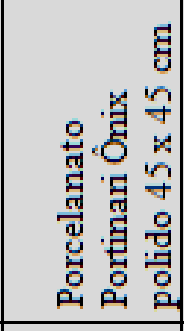 & 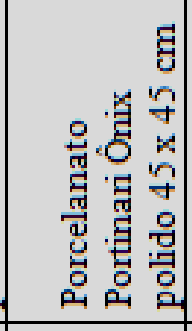 & 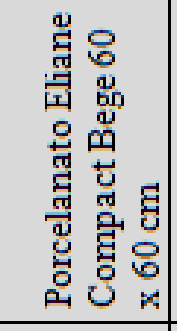 & 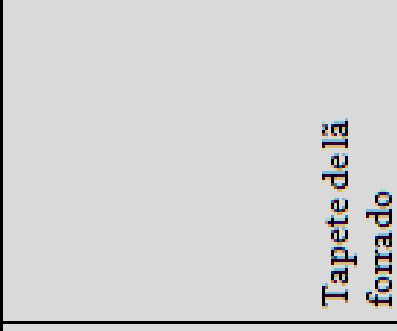 \\
\hline 잉 & $\vec{B}_{1}$ & a & a & a & $\hat{\Omega}$ & $\stackrel{\infty}{\circ}$ \\
\hline 至 & 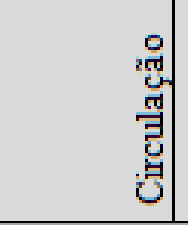 & 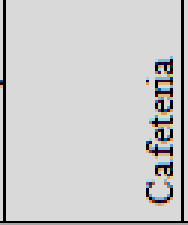 & 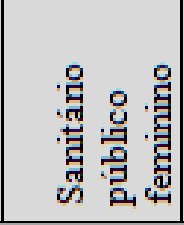 & 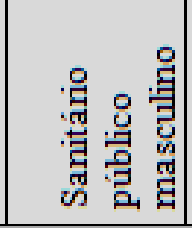 & 莺 & . \\
\hline \multicolumn{7}{|c|}{ OLN'GWLVE } \\
\hline
\end{tabular}




\begin{tabular}{|c|c|c|c|c|c|c|c|}
\hline | & 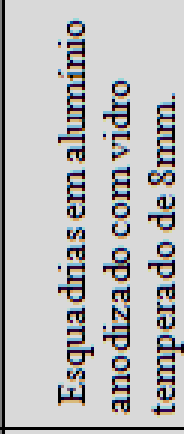 & 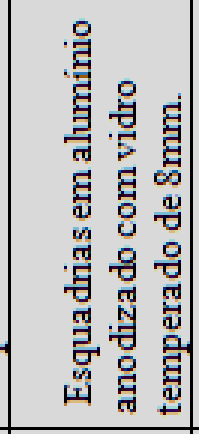 & 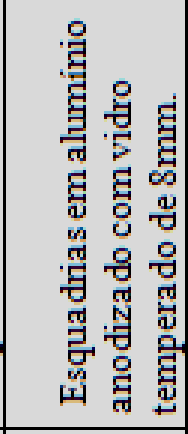 & 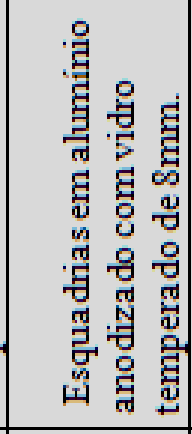 & 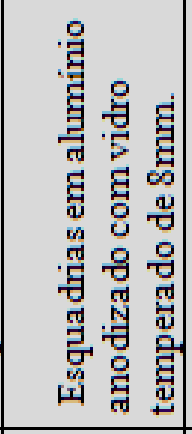 & 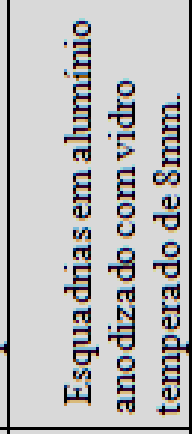 & 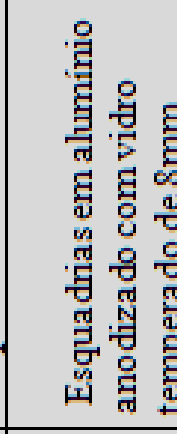 \\
\hline 8 & 可 & 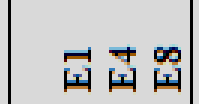 & 式 & 匀 & $\begin{array}{l}n \\
0\end{array}$ & 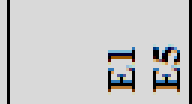 & 国氠吉 \\
\hline 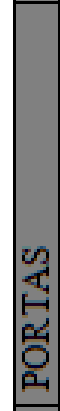 & 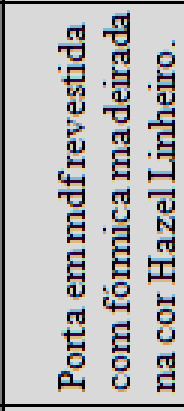 & 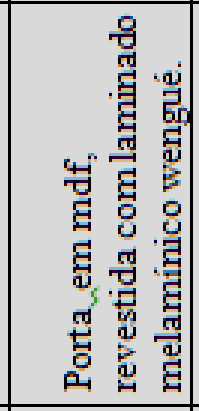 & 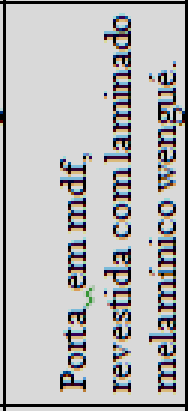 & 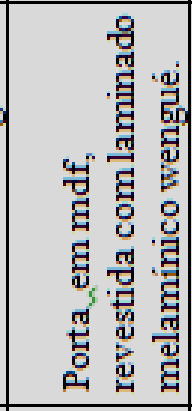 & 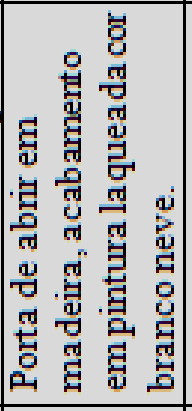 & 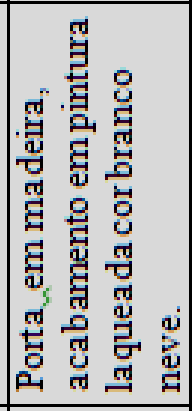 & 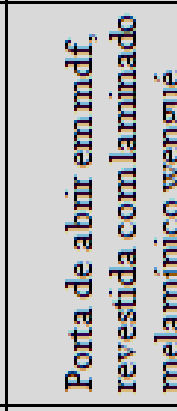 \\
\hline ठठ & $\ddot{n_{1}}$ & $\hat{\omega_{1}}$ & ڤี & מ & $\mathcal{S}_{1}^{1}$ & 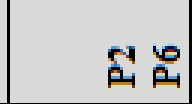 & \\
\hline 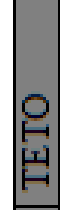 & 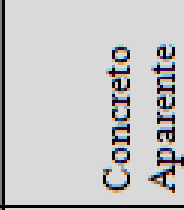 & 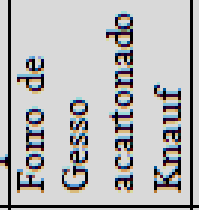 & 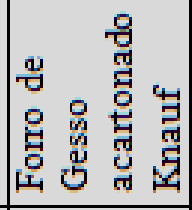 & 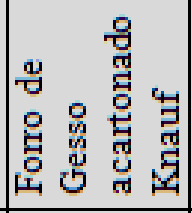 & 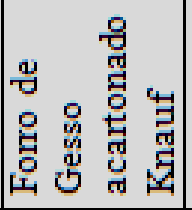 & 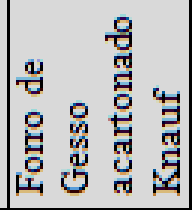 & 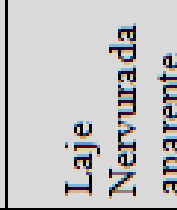 \\
\hline 8 & 㞋 & 到 & Z & F & $\mathcal{G}$ & $\mathcal{Z}$ & E \\
\hline 部 & 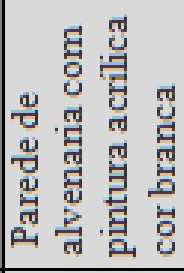 & 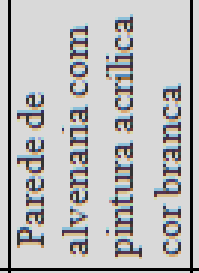 & 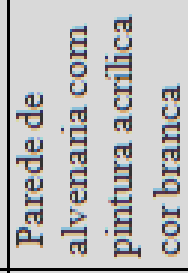 & 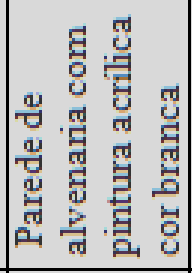 & 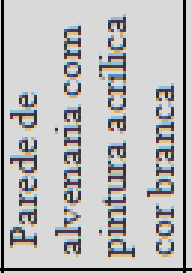 & 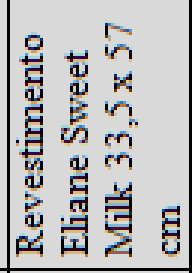 & 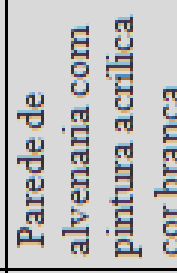 \\
\hline |ి & 2 & 2 & 2 & 勻 & 2 & 2 & p \\
\hline $\begin{array}{l}\text { 号 } \\
\text { 㟧 }\end{array}$ & 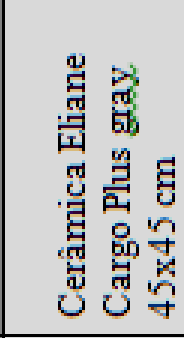 & 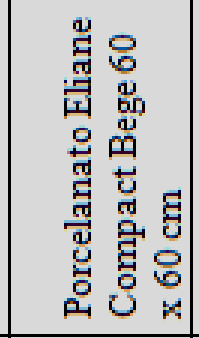 & 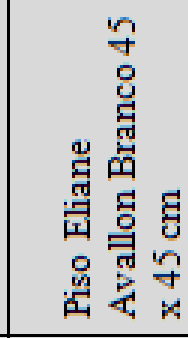 & 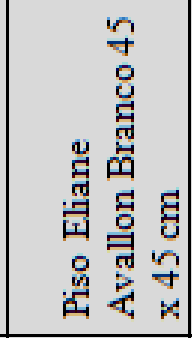 & 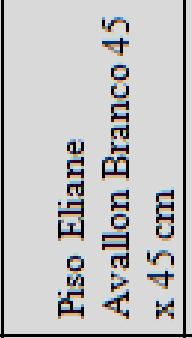 & 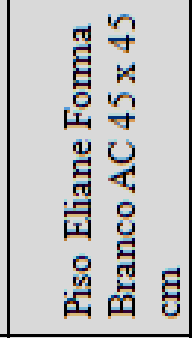 & 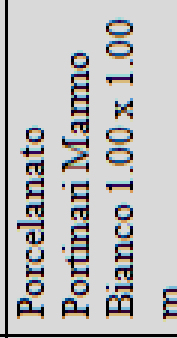 \\
\hline Ö & $\hat{D}_{1}$ & $\hat{\aleph}_{1}^{\prime}$ & $\ddot{1}$ & $\tilde{\mu}_{1}$ & $\tilde{\tilde{A}_{1}}$ & ڤ. & a \\
\hline 罝 & 学 & 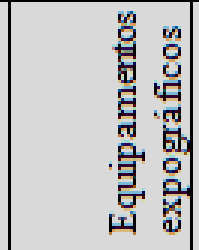 & 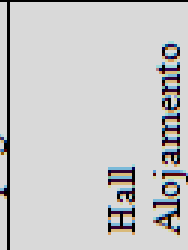 & 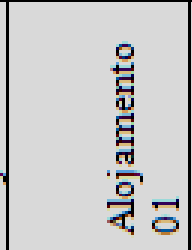 & 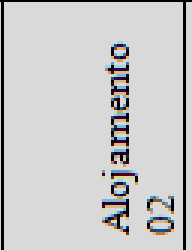 & 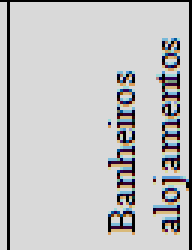 & 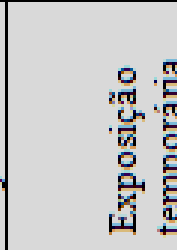 \\
\hline \multicolumn{8}{|c|}{ O.LNGWLAVd $\mathcal{E}$} \\
\hline
\end{tabular}




\subsection{SIMULAÇÃO TRIDIMENSIONAL}

Visando a melhor visualização da proposta arquitetônica, foram feitas as seguintes imagens, com auxílio do programa 3dmax:

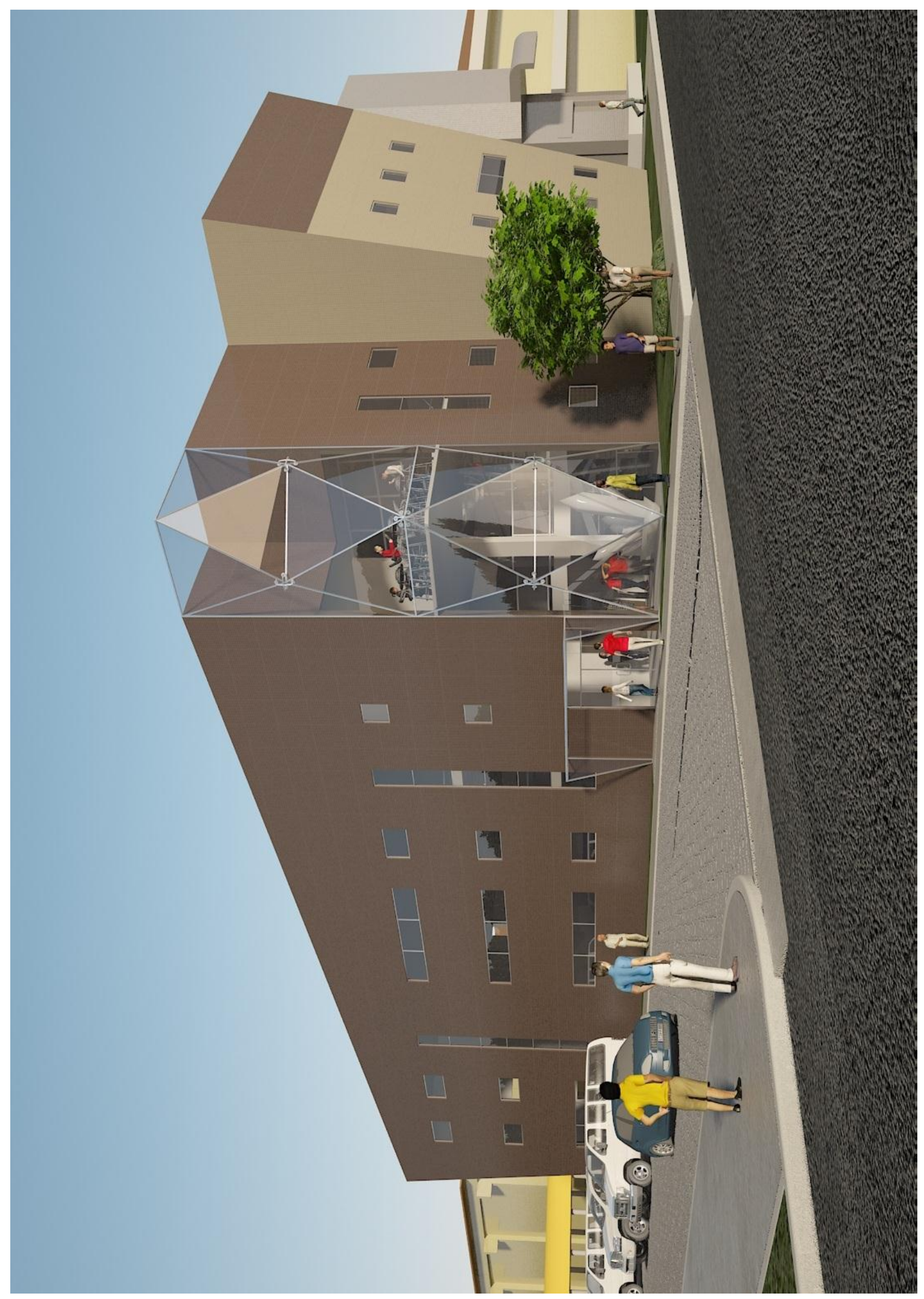

Figura 120: Simulação Tridimensional Externa. 


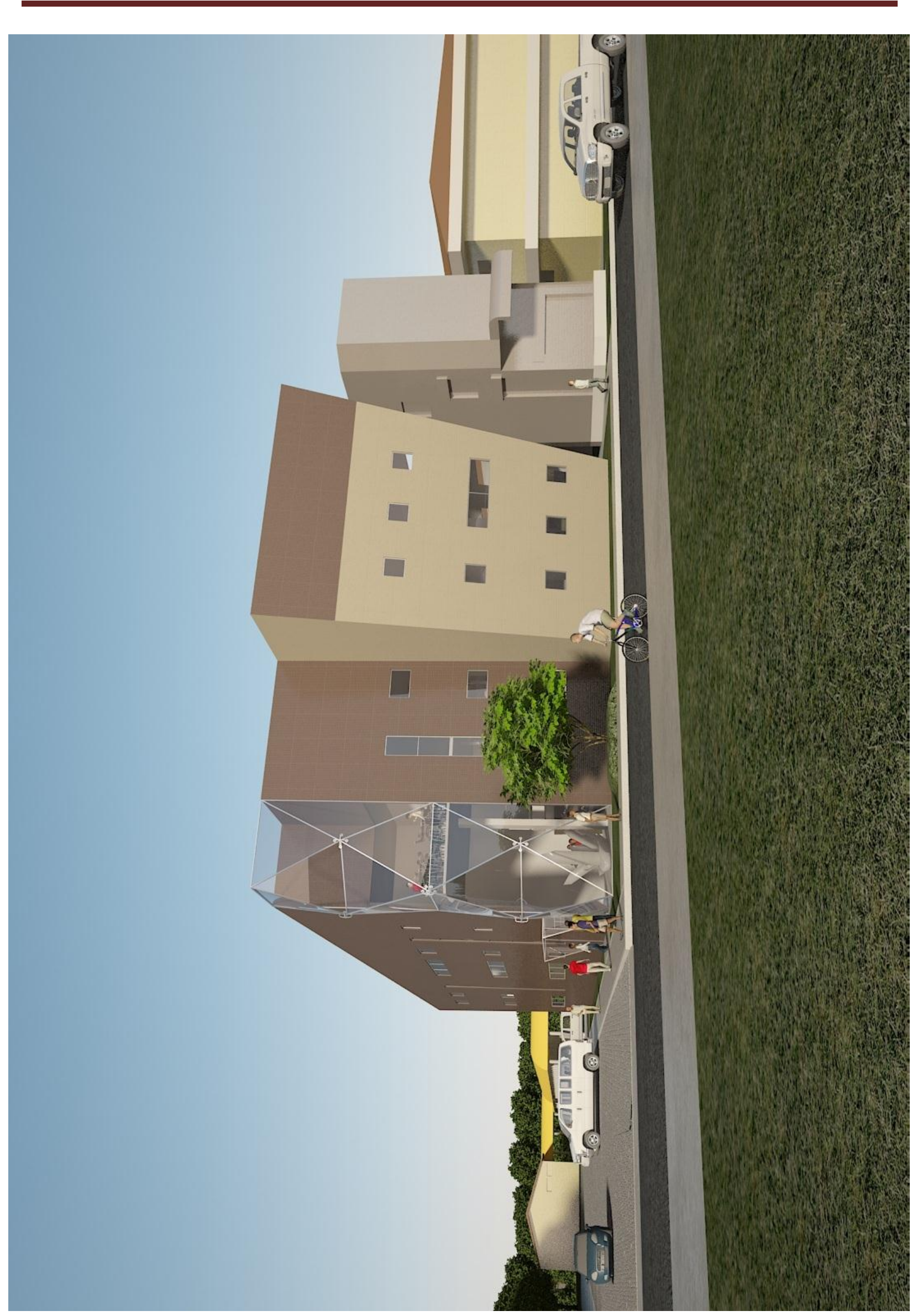

Figura 121: Simulação Tridimensional Externa. 


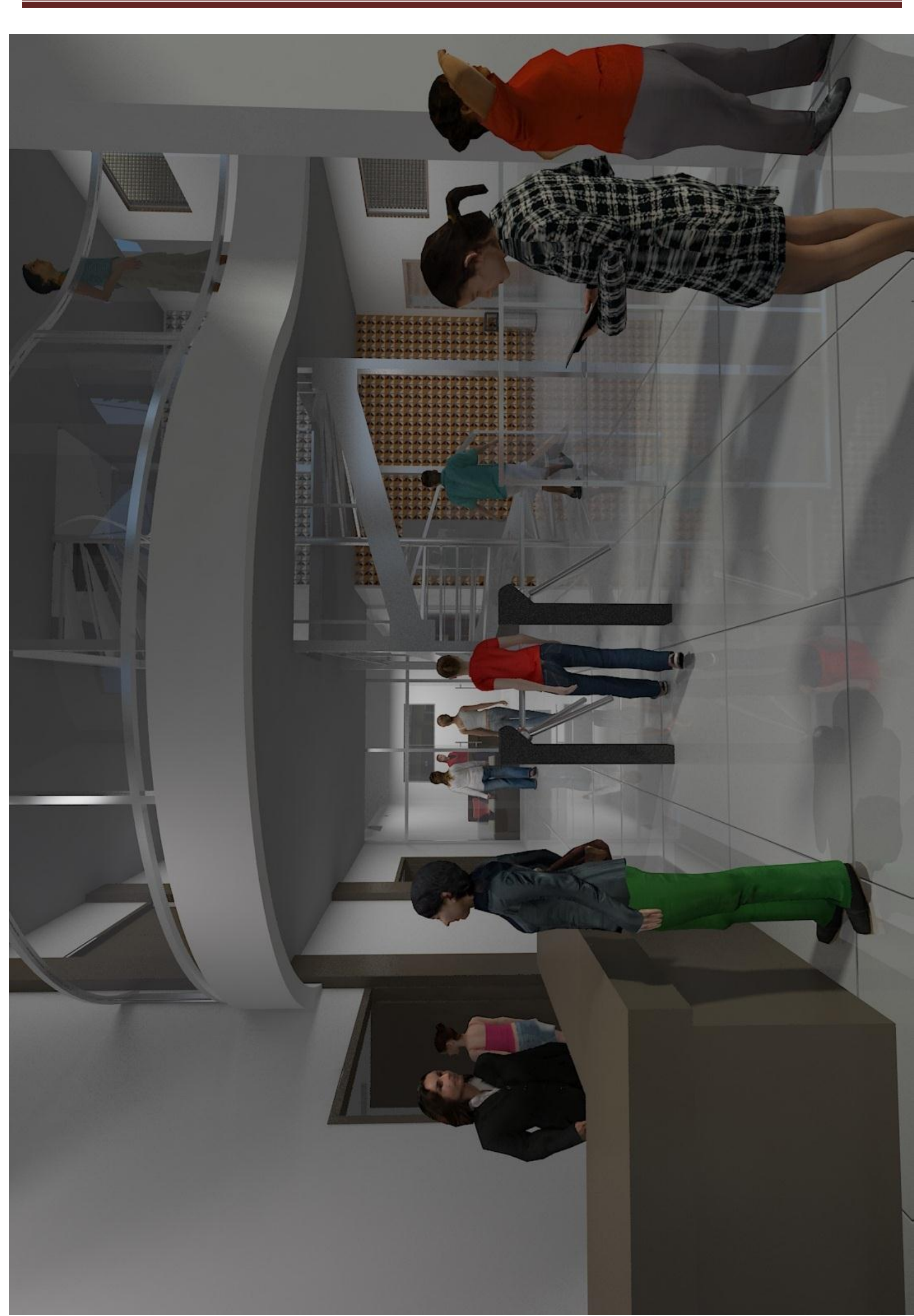

Figura 122: Simulação Tridimensional Interna. Hall de Entrada. 


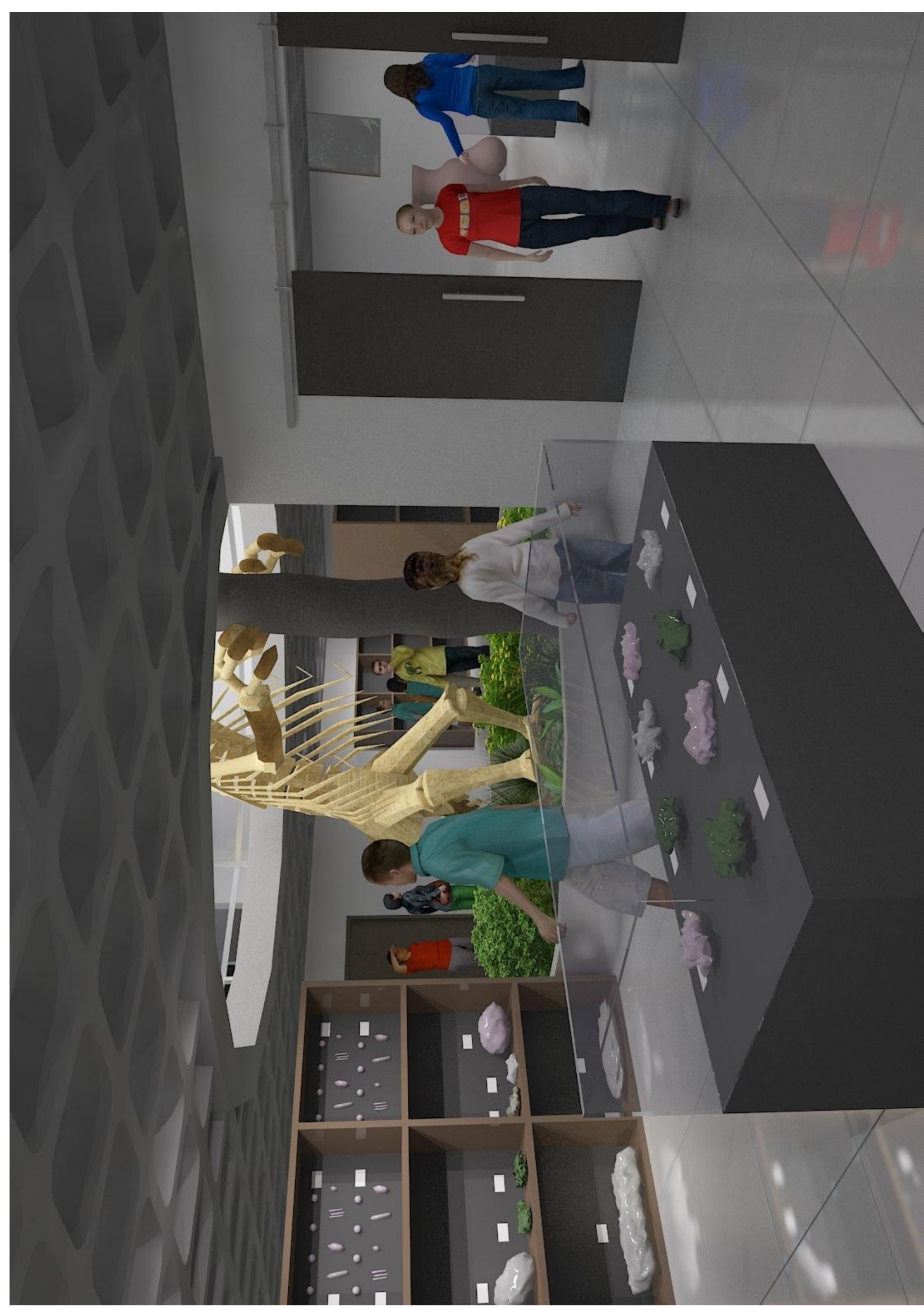

Figura 123: Simulação Tridimensional Interna. Exposição Permanente 


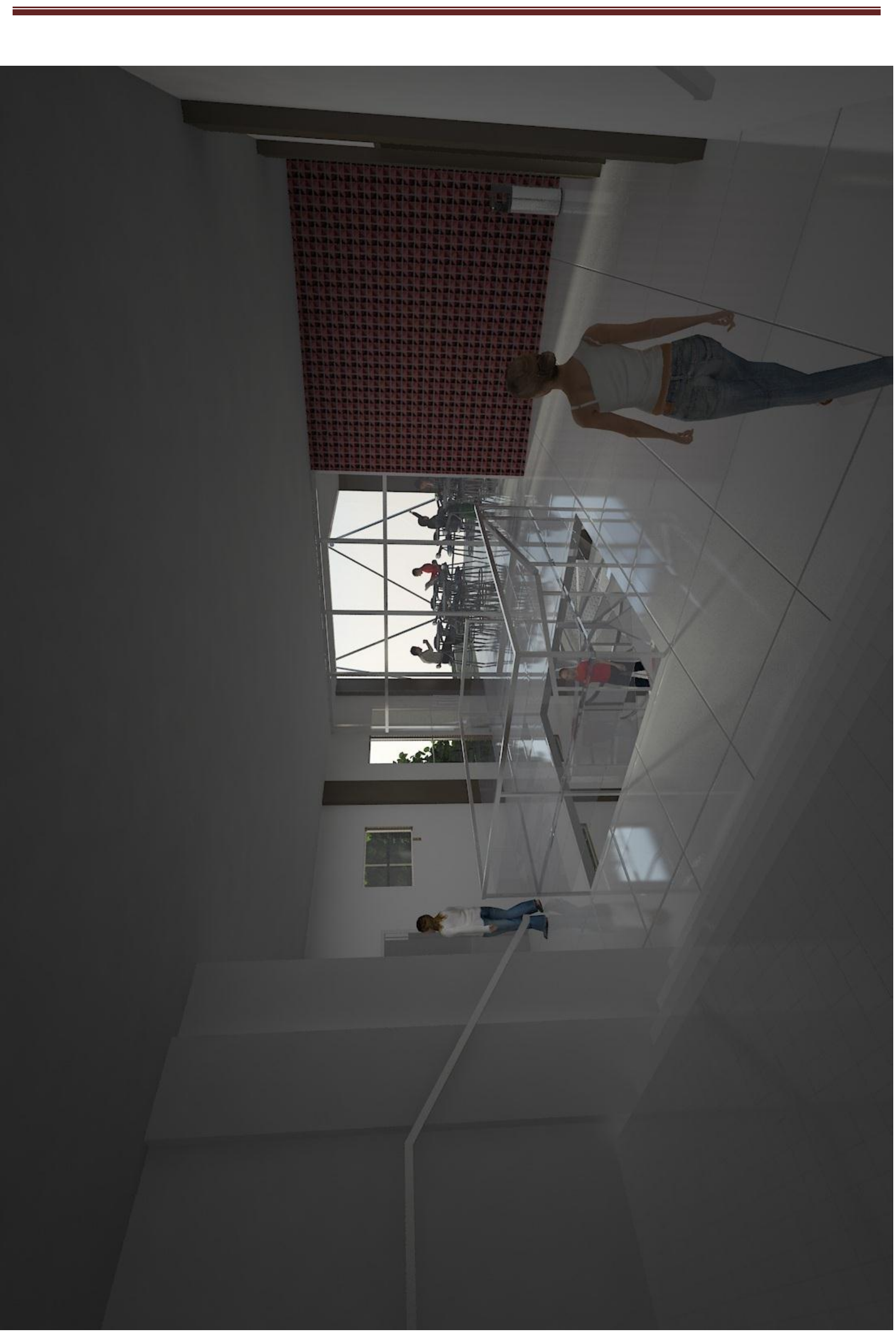




\section{CONCLUSÕES}

No presente trabalho foi exposta a importância acerca do conhecimento dos princípios fundamentais de composição formal, de modo a compreender o que significa, de fato, compor. Foi dessa forma, sugerido por meio dessa análise, a vinculação desses conceitos a proposta arquitetônica do Museu de História Geológica da Amazônia.

Em seguida a pesquisa dos princípios norteadores da forma, se discutiu a influência dos meios tecnológicos e artísticos sobre a arquitetura, objetivando com isso, imbuir a proposta aqui defendida, de propriedades compositivas essenciais à prática da boa arquitetura.

Em um segundo momento, pesquisou-se sobre o objeto de estudo aqui analisado, os museus. Dessa pesquisa, é nítida a percepção das modificações sofridas pelas instituições museais ao longo dos séculos, modificações estas que foram refletidas tanto no espaço físico utilizado, quanto nas atividades desenvolvidas. Tais transições ocorreram mantendo um ponto comum entre as instituições ao longo dos anos: o de salvaguarda do patrimônio e fonte de conhecimento.

Com o decorrer da pesquisa realizada, a mesma foi direcionada para a cidade de Belém. A capital do estado do Pará acompanhou o processo de transição dos museus, possuindo uma série de edificações voltadas para esse segmento. Todavia, não possui, ainda, um espaço físico projetado especificamente para atender à função museológica.

Belém também enquadra suas instituições museais no contexto da sociedade contemporânea, em que os museus atendem a diversas funções. Além de preservar o patrimônio, eles estão vinculados a atividades acadêmicas, pesquisas, intercâmbios de informações e estímulo do turismo local. Com isso, a atual arquitetura museal é projetada de modo a englobar diversos setores dentro do museu.

O Museu de Geociências da Universidade Federal do Pará insere-se nesse contexto, possuindo um vasto acervo, o qual pode ser expandido por meio das pesquisas realizadas pelo Grupo de Mineralogia e Geoquímica Aplicada, e participando ativamente das atividades do Instituto de Geociências.

Com as informações obtidas por meio da revisão bibliográfica e pesquisas realizadas durante este trabalho, a solução encontrada para o projeto arquitetônico da nova sede do 
Museu de Geociências, agora com o título de Museu de História Geológica da Amazônia, atingiu o intuito desejado, de projetar um espaço físico ideal para abrigar a coleção do museu, e dar espaço para atividades relacionadas à pesquisa, e educação, em associação a um partido arquitetônico atrativo, com elementos voltados para a arquitetura mineral, sem estar desvinculado do entorno, neste caso, o campus universitário.

Por fim, é válido ressaltar que o projeto executivo de um museu é um trabalho interdisciplinar, necessitando de outros profissionais, além do arquiteto, para compor os espaços expositivos. Desdobramentos possíveis desta proposta arquitetônica envolvem a participação efetiva de museólogos e educadores. 


\section{REFERÊNCIAS BIBLIOGRÁFICAS}

ARGAN, Giulio Carlo. Arte Moderna. Editora Cia das Letras. 1999.

ARNHEIM, Rudolf. Arte e percepção visual. São Paulo: Pioneira, 1997.

AltaBA, M. F.; MIGUEL, A.S. Atlas de Geologia. Tradução de Fausto Luiz De Souza Cunha. Rio de Janeiro: Editora Edicione, 1975.

BANHAM, Reyner. Teoria e Projeto na Primeira Era da Máquina. Tradução de A. M. Goldberger Coelho. São Paulo: Perspectiva, 1975.

BENEVOLO, Leonardo. História da Arquitetura Moderna. Editora Perspectiva, 2001.

BOTElHO, M. H; MARCHETTI. O. Concreto Armando Eu te amo. São Paulo : Editora Edgard Blucher, 2002.

BOTTOM, Allain. Arquitetura da Felicidade. Tradução de Talita M. Rodrigues. Rio de Janeiro: Editora Rocco, 2007.

BRAICK, P. R; MOTA, M. B. História das Cavernas ao Terceiro milênio. São Paulo: Editora Moderna, 2002.

CESAR, Newton. Os primeiros segredos da direção de arte. Brasília: Editora Senac Distrito federal. 2009.

CHING, F. D. K. Arquitetura, forma, espaço e ordem. Tradução de Alvamar Helena Lamparelli. São Paulo: Martins Fontes, 2005.

CURTIS, W. J. R. Arquitetura moderna desde 1900. 3. ed. São Paulo: Editora Artmed, 2008.

DEMPSEY, Amy. Guia enciclopédico da arte moderna. São Paulo: Cosac \& Naify, 2003.

FRAMPTON, Kenneth. História crítica da arquitetura moderna. Tradução de Jefferson Luiz Camargo. São Paulo: Editora Martins Fontes. 2008.

INSTITUTO BRASILEIRO DE MUSEUS /MINISTÉRIO DA CULTURA, Guia dos Museus Brasileiros. Brasília, 2011.

KOTHER, M. B. M. Arquitetura \& Urbanismo: Posturas, tendências e reflexos. Porto Alegre: EDIPUCRS, 2006.

FUndaÇÃO CUltural DO MUNICÍPIO DE BELÉM. Palácio Antônio Lemos Museu de Arte de Belém. Belém, 1996. 
GURGEL, Miriam. Projetando espaços - arquitetura de interiores para áreas residenciais. São Paulo: Editora Senac, 2007.

GYORGY, Doczi. O poder dos limites: Harmonias e proporções na natureza, arte e arquitetura. Tradução de Maria Helena de Oliveira Tricca e Júlia Bárány Bartolomei. São Paulo: Editora Mercury, 1990.

LE CORBUSISER. Por uma arquitetura. Tradução de Ubirajara Rebouças. São Paulo: Perspectiva. 1997. Título original: Vers une architecture. In: L’ espirit noveau. 1923.

MAHFUZ, Edson. Ensaio sobre a razão compositiva. Belo Horizonte, Editora Ap Cultural. 1995.

MAHFUZ, Edson. Reflexão sobre a base téorica da prática moderna. In: DOCOMOMO BRASIL, $8^{\circ}$ Seminário. Cidade Moderna e Contemporânea. Rio de Janeiro: 2009.

MALARD, M. L. As aparências em arquitetura. Editora UFMG. 2006.

MARTINEZ, A.C. Ensaio sobre o Projeto. Tradução de Ane Lise Spaltemberg. Brasília: Editora UnB, 2000.

MEYER, Diogo. EL-HANI, Charbel. Evolução - o sentido da biologia. São Paulo: Unesp. 2005 .

MONTANER, Josep Maria. Museus para o século XXI. Tradução de Eliana Aguiar. Barcelona. 2003.

NORMAN, Donald A. Design emocional: por que adoramos (ou detestamos) os objetos do dia-a-dia. Tradução de Ana Deiró. Rio de Janeiro: Editora Rocco,2008.

PEVSNER, Nikolaus. Os Pioneiros do desenho moderno. São Paulo: Martins Fontes. 2002. PIÑÓN, Hélio. Teoria do Projeto. Tradução de Edson Mahfuz. Porto Alegre: Livraria do Arquiteto, 2006.

RANGEL, M. F. O Museu e o Patrimônio no mundo contemporâneo. In: RODRIGUES, C.S. et e al. Um olhar contemporâneo sobre a preservação do patrimônio cultural material. Museu Histórico Nacional. Rio de Janeiro, 2008.

RIBEIRO, J. A.F. S. A arquitetura do Museu. In: ROCHA-TRINDADE, M. B. Iniciação à Museologia. Lisboa, Universidade Aberta. 1993.

RODHE, G. M. Simetria: rigor e imaginação. EDIPUCRS, 1997. 
SÃO PAUlO, Secretaria de estado da cultura. Conservação, Postura e Procedimentos. São Paulo, 1998.

STRICKLAND, Carol. Arquitetura Comentada - Uma breve viagem pela história da arquitetura. Ediouro 2003.

SCULLY, Vincent. Arquitetura Moderna. Arquitetura da Democracia. São Paulo: Cosac \& Naify, 2002.

UFPA; Prefeitura da Cidade Universitária. Plano Diretor da Cidade Universitária da UFPA. Belém: UFPA, 2010. CD-ROM.

VITRÚVIUS, Marcus Pollio. Tratado de Arquitetura. Tradução de M. Justino Maciel. São Paulo, Editora Martins Fontes. 2007.

\section{GALERIAS DE IMAGENS:}

http://www.cimento.org/site/concreto.htm

http://www.britannica.com/EBchecked/topic/372380/Medici-Family.htm

http://masp.art.br/masp2010/sobre_masp_galeria.php

http://www.niemeyer.org.br.

http://www.diarioonline.com.br/guia-detalhes-premium.php?id=73

http://www.saojoselibertoigama.blogspot.com/p/o-espaco.html 


\section{ANEXOS}

ANEXO A - Mapa da divisão territorial da Cidade Universitária Prof. José da Silveira Netto.

ANEXO B - Mapa e Tabela de Taxa de Ocupação da Cidade Universitária Prof. José da Silveira Netto.

ANEXO C - Mapa e Tabela de Coeficiente de Aproveitamento da Cidade Universitária Prof. José da Silveira Netto.

ANEXO D - Mapa de Afastamentos da Cidade Universitária Prof. José da Silveira Netto.

ANEXO E - Mapa do Gabarito de Entorno de Monumentos da Cidade Universitária Prof. José da Silveira Netto.

ANEXO F - Mapa de Zoneamento do Uso do Solo da Cidade Universitária Prof. José da Silveira Netto.

ANEXO G - Mapa de Áreas de Preservação da Cidade Universitária Prof. José da Silveira Netto. 